Restorative Justice and the Global Imagination

Audrey Josephine Golden

Charlottesville, Virginia

Juris Doctor, Wake Forest University School of Law, 2009

Bachelor of Arts, Wesleyan University, 2006

A Dissertation presented to the Graduate Faculty of the University of Virginia in Candidacy for the Degree of Doctor of Philosophy

Department of English Language and Literature

University of Virginia

August, 2014 


\section{Table of Contents}

Introduction: Nuremberg, International Human Rights Law, and the Narrative

Foundations of Restorative Justice........................................... 1

Recovering Arthur Koestler's Darkness at Noon: Literary Fictions, Bodily Restoration, and the Politics of the Totalitarian Novel............................ 43

Remaking the Historical Record: Remedies for the former Yugoslavia and Aleksandar Hemon's The Question of Bruno.

The 'Terrible Genius of Literature': Post-Apartheid Reconciliation in Nadine Gordimer's The House Gun................................................ 153

Coda: A Future for Recuperative Global Narrative.................................. 210

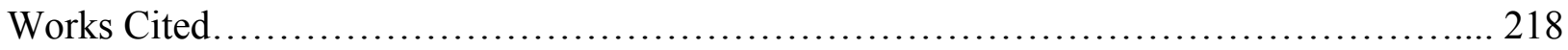




\section{Introduction:}

\section{Nuremberg, International Human Rights, and the Narrative Foundations of Restorative Justice}

I am consoled by the fact that in proceedings of this novelty, errors and missteps may also be instructive to the future.

-Justice Robert H. Jackson, closing out his report to then-President Truman on the Nuremberg Trials

We gradually came to accept the depravity of the Holocaust, but then slotted it in our consciousness as 'history'; we resisted acknowledging that genocide was occurring in the present. Survivors and witnesses had trouble making the unbelievable believable. Bystanders were thus able to retreat to the 'twilight between knowing and not knowing.'

- Samantha Power, A Problem from Hell

In late 2010, the "Court Room 600” museum opened in Nuremberg, Germany at the Nuremberg Palace of Justice, where the International Military Tribunal (IMT) trials were held between 1945-46. The trials officially concluded in 1948 with the close of the tribunal for the Far East (IMTFE), in which Japanese war criminals were tried. More than sixty years after the close of the World War II trials, public interest sparked the opening of the museum, suggesting that Nuremberg and its cultural significance remained salient in second-generation memory. How do the crimes of the Holocaust show themselves in relation to twenty-first century juridical paradigms? Numerous accounts of cultural memory have sought to address the ways in which wounds of the past might be healed or tempered through "museumification" and construction of memorial sites. ${ }^{1}$ Yet these accounts tend to disconnect social knowledge of mass crime from that acquired through international legal processes. Certainly, museums do much to begin the

\footnotetext{
${ }^{1}$ See Huyssen, Present Pasts and Twilight Memories, for discussions of the "museumification" of contemporary culture.
} 
process of restoring dignity to victims of mass violence, but the relationship between juridical inquiry and narrative more closely attends to new forms of healing that encompass both political and cultural concerns.

Between 1961 and 1993, employees at the Nuremberg Palace of Justice—which has been used as a court since the early 1960s for criminal trials—noticed visitors standing outside the building, hoping to gain entry to sneak a peek inside the internationally famous Court Room 600 . A curator, Henrike Zentgraf, explained that visitors asked how they could get in, and some were admitted entry on a small scale. Employees began keeping records of the number of visitors to the site and counted approximately 3,000 within the thirty-year period. By the mid-1990s, however, even more travelers from the United States, the United Kingdom, Russia, Japan, and China began appearing outside the Palace of Justice throughout the week, seeking entry into the building. Between the mid-1990s and the early 2000s, the number of visitors had risen to more than 20,000. Zentgraf believes that the sharp increase in domestic and international visitors implies a direct link to the creation of the international criminal tribunals for the former Yugoslavia (ICTY) and for Rwanda (ICTR) in 1993 and 1994. "Nothing else could account for people visiting the tribunal during the week," she said. ${ }^{2}$

Can the rising number of visitors to the Nuremberg Palace of Justice provide evidence of a connection between the IMT and the re-creation of international criminal tribunals in the 1990s? Historical and sociological inquiries have suggested that Zentgraf's assumption is right. ${ }^{3}$ What knowledge do visitors hope to acquire? What can be gleaned from a space that has been radically transformed from its 1945 incarnation? ${ }^{4}$ Notably, visitors to the museum can learn that

\footnotetext{
${ }^{2}$ Interview with Henrike Zentgraf, Nuremberg, Germany. July 23, 2012.

${ }^{3}$ See, for example, David Scheffer.

${ }^{4}$ Zentgraf emphasizes that the Court Room 600 museum does not spatially resemble the room used to prosecute Nazi war criminals. In fact, Court Room 600 was "refurbished" specifically for the trials, and "refurbished" again
} 
the trials admitted no visitors and only a handful of victim witnesses in the 1940s. Zentgraf describes the IMT's treatment of these witnesses as "horrible, it is horrible to look on the way victims were treated in Nuremberg." ${ }^{5}$ In Germany, at least, there exists a distinct need to recover the history of criminality during the Nazi regime and to consider the politics of "healing" the sites that contain it. ${ }^{6}$ Marina Christmeier, a curator of the Nazi Documentation Center in Nuremberg, emphasizes that museums are performing extra-legal work of "looking forward," moving away from a culture of adversarial interaction and into one focused on "a new image, of human rights and freedom." ${ }^{, 7}$ By its backward-looking nature, retributive justice stands in opposition to restorative justice, which aims to provide healing and reconciliation to victims of mass violence.

My study arose from a double perception: the absence of initiatives in restorative justice within international law, and the manifold attention to human recovery in the postwar novel. Novelists, in short, have imagined scenes of restoration while international jurisprudence has focused primarily on punishing perpetrators. This study brings together writers in exile, nonnative speakers writing in English, and Anglophone novelists engaging with continued matters of the postcolonial. It is framed by the 1945 International Military Tribunal (IMT) for Nuremberg on one hand, and the establishment of the 1993 International Criminal Tribunal for the Former Yugoslavia (ICTY) and the 1995 Truth and Reconciliation Commission (TRC) for South Africa on the other. Individual chapters engage the works of Arthur Koestler, Aleksandar Hemon, and Nadine Gordimer to explore new models of restorative justice in the wake of political violence.

with its reopening for court in 1961. One of the only remnants of the original trial room were two benches that had been stored in the basement of the Palace of Justice since 1946. In 2008, an employee pointed out that the benches were in the basement, and they were taken out and restored to be part of the exhibition that visitors now see.

${ }^{5}$ See Zentgraf interview.

${ }^{6}$ Interview with Martina Christmeier, Documentation Center, July 22, 2012. Christmeier explained how new discussions emerged in the mid- to late-1990s about how to deal with the decaying sites of the Nazi regime, such as the parade grounds.

${ }^{7}$ See Christmeier Interview. 
The readings will suggest that literary reckonings with restorative justice occur not just within the bounds of particular novels, but through texts that have developed a literary dialogue across the decades. Those that speak to totalitarianism in Nazi Germany and the Soviet Union, for instance, have been answered by novels about the 20th-century endemic violence in the Balkans and the reconciliatory possibilities in a South Africa still contending with its long history of state-sanctioned racism.

The Nuremberg trials prosecuted high-ranking Nazis from November 20, 1945 to October 1, 1946. Strategically held in Nuremberg, the cultural center of Nazi Germany, representatives from the United States, England, France, and the Soviet Union came together to try crimes against humanity in the first international tribunal of its kind. After much deliberation, the prosecution team decided to hold the trials in the Nuremberg Palace of Justicea symbolic structure in which to hold German war criminals accountable. ${ }^{8}$ I argue that the anecdotes about the site of the trials stress an important sociological shift in thinking about justice after political violence. The significance of Nuremberg remains in public memory, but elicits a need for understanding the past and using it for the future. Rather than focus on the backward-looking terms of punishment and retribution enacted at the IMT trials, the cultural outcry at the Palace of Justice provides an opportunity for us to rethink the question of restorative justice through the labor of narrative imagination. Indeed, as Ravit Reichman has maintained, the Nuremberg Trials present a key moment for exploring the relationship between the work of literary modernism and the efficacy of law. ${ }^{9}$

The dissertation explores the intersection of the global Anglophone novel with international human rights law from the end of World War II to the early twenty-first century. It

\footnotetext{
${ }^{8}$ See Jackson journal.

${ }^{9}$ Ravit Reichman, "Committed to Memory: Rebecca West's Nuremberg," in Law and Catastrophe, eds. Austin Sarat, Larence Douglas, and Martha Merrill Umphrey (Stanford: Stanford UP, 2007), 91-130.
} 
challenges the retributive aims of the criminal tribunal system and the remedial legal adage of "making whole" a victim, and argues for the prominence of imaginative literature in the critical discourse surrounding restorative justice. Contending with international laws largely created by and modeled upon American jurisprudence, ${ }^{10}$ my work brings Anglophone fiction into conversation with human rights proceedings that assert their globality. In this study, the "global novel" refers to a form of recuperative fiction that emerges as a vehicle for considering the restorative power of narrative. In relation to the retributive focus of jurisprudence, I envision the global novel as a broad and far-reaching form in which language and narration depict distinct forms of victim recovery.

The project begins by radically reframing Koestler's Darkness at Noon (1940). Rather than conceive of the novel as one defined by Cold War ideology, I argue that it reimagines the nature of human recovery at the height of Stalinist terror and the beginning of WWII. For Bosnian-immigrant novelist Hemon, restoration carries additional weight. Accordingly, I show how his first work, The Question of Bruno (2000), challenges the remedial limitations of the ICTY, recovering a literary-historical record of violence in the Balkans. I conclude with Gordimer's The House Gun (1998), demonstrating how the novel broadens and enlivens the nature of reconciliation as it is imagined within South African jurisprudence. In a nation defined anew by its emphasis on restorative justice, the novel lays a foundation for repairing the individual, domestic, and spatial injuries of apartheid.

The possibility of bringing together these seemingly distinct texts in a global "wave pattern," as David Damrosch might describe it, ${ }^{11}$ relies upon the practices and limitations of the

\footnotetext{
${ }^{10}$ In a lecture at the University of Virginia, Richard Goldstone articulated that international criminal law "would not exist" without American constitutional law. See Lecture at the University of Virginia, March 15, 2012.

${ }^{11}$ In "World Literature in an Postcanonical, Hypercanonical Age," Damrosch proposes teaching literature in "wave patterns," or putting together texts that might at first seem disparate but provide new insights when read together.
} 
international criminal tribunal system. The creation of the IMT and its predecessors raises significant questions about the nature of justice and the ways victim recovery plays into such a definition, and that history begins at Nuremberg.

\section{History Begins at Nuremberg}

The international criminal tribunals, including the IMT at Nuremberg, have unavoidably raised the question of restorative justice. In a conference session for the IMT, Robert $\mathrm{H}$. Jackson, the American Chief Prosecutor at Nuremberg, made clear that one of the aims of the trials was establishing its rehabilitative power for future generations. "If we look only to the past with our action," he spoke, "it will be of little importance for the future."12 Indeed, thinking in the same legal terms that would later be used to construct the UDHR and the Genocide Convention, Jackson emphasized that the crimes against humanity perpetrated by the Nazi war criminals "destroyed all judicial remedies for the citizen and all protections against terrorism." Jackson was no stranger to the forward-looking implications of Nuremberg, and his meetings with members of the Institute of Jewish Affairs (IJA) confirmed the presence of a 'victim lobby' in the trials' creation. ${ }^{14}$ In a personal journal he kept during the planning period for the trials, he recorded a meeting with Dr. Jacob Robinson: "Dr. Robinson ... said my report was like rain on the desert to the Jews, that while others were looking for precedent [to prosecute the Nazis] in

\footnotetext{
${ }^{12}$ Robert H. Jackson, "Minutes of Conference Session of July 19, 1945" in Report of Robert H. Jackson, United States Representative to the International Conference on Military Tribunals (Washington: Department of State, 1949), 298.

${ }^{13}$ Robert H. Jackson, "Report to the President by Mr. Justice Jackson, October 7, 1946" in Report of Robert H. Jackson, United States Representative to the International Conference on Military Tribunals (Washington: Department of State, 1949), 439.

${ }^{14}$ Lawrence Raful, "A Jewish Lobby at Nuremberg: Jacob Robinson and the Institute of Jewish Affairs, 1945-46, in The Nuremberg Trials: International Criminal Law Since 1945, ed. Herbert R. Reginbogin et al., (Munich: K.G. Saur, 2006), 71.
} 
the 17th or 18th Centuries, mine were taken from the 22nd Century." ${ }^{, 15}$ Robinson also provided Jackson with a path to thinking about Jewish victimhood, arguing that the trials should have an amicus curiae "to represent the six million slaughtered," the Jewish people as the victim of the Nazi fury." ${ }^{, 17}$ Herbert Swope echoed the need for victim involvement. Jackson recorded Swope's appeal for "a panel of all victims of persecution."18 In a journal entry dated April 27, 1945, Jackson wrote that "the trial of these war-guilt cases must be prompt and must be over with before the public turns to other things if they are to serve any real purpose." During the planning stages, U.S. senators gave input into the structure and substance of the trials. Senator Fulbright of Arkansas specifically opposed the creation of an international tribunal, telling Jackson that "a trial would result in great delays and that it would give the defendants a chance to tell their stories where all the world can hear them." ${ }^{, 19}$ Indeed, many of the senators favored swift executions in lieu of a courtroom proceeding. By June 1, as plans for the Nazi trials were underway, Jackson recorded a conversation with then-President Harry S. Truman, who emphasized an urgency to "get that trial done and get this crimes business back of us." From the beginning, the International Military Tribunal for Nuremberg (IMT) focused on retributive justice, or punishing high-ranking Nazis for their respective roles in perpetrating World War II.

Notably, the only reference to restoration or recovery (die Wiedergewinnung) at Nuremberg came from the defense and referred to physical structures erected by the Nazi regime. These documents are housed at the Stadtarchiv in Nuremberg and point researchers to a

\footnotetext{
15 Jackson journal, Tuesday, June 11, 1945.

16 Ibid.

${ }^{17}$ General Report to the Combined Staffs of the Office by Dr. Jacob Robinson on the Nuremberg War Criminals Trial, Thursday, December 6, 1945. World Jewish Congress archives.

${ }^{18}$ Jackson journal, Tuesday, June 11, 1945.

${ }^{19}$ Jackson journal, May 16, 1945.
} 
small neighborhood of single-story buildings on the outskirts of the city. They were erected with funding from the Third Reich in a "recovery" project aimed at Germans who had suffered economically in the years following World War I. ${ }^{20}$ These houses were unscathed by the Allied bombings during the war, and they remain standing today as the only markers of restoration in Nuremberg. As such, references to restorative justice remain outside the primary historical narrative of the trials contained at the National Archives in the U.S. ${ }^{21}$

From 1945-46, Jackson focused his trial strategies on retribution for the Nazi perpetrators. Indeed, only three victims were permitted access to the courtroom to view the proceedings, and no measures accounted for victim rehabilitation in the aftermath. Any mentions of repair focused on the "Reparations Commission," which was not actually victimcentered. Instead, it aimed to find a way to require the Nazi perpetrators to engage in forced labor to restore the land and infrastructure that had been damaged during the war. ${ }^{22}$ In a closing report to President Truman written at the end of the Nuremberg trials, Jackson emphasized that the trial had not enacted a complete form of justice, stating that "any report would be incomplete and misleading which failed to take account of the general war crimes that remains undone and the heavy burden that falls to successors in this work." ${ }^{23}$ However, Jackson quickly emphasized that "a very large number of Germans who have participated in the crimes remains unpunished."

\footnotetext{
${ }^{20}$ For images of these buildings, see Katharina Blohm et al., Bauen im Nationalsozialismus: Bayern 1933-45 (Muenchen: Architekturmuseum der Technischen Universitaet Muenchen, 1993), 144.

${ }^{21}$ According to Zentgraf, "what you find in Germany is an archival situation of documents from the defense, left in different archives in Germany because they probably didn't know of these documents or weren't interested in taking them with them and archiving them with the other IMT documents."

${ }^{22}$ Jackson journal, May 4, 1945. Ideas of "reparation" again place the perpetrators at the fore: "It was agreed at Yalta that reparation in kind is to be exacted from Germany, partly through the use of German labor."

${ }^{23}$ Robert H. Jackson, "Report to the President by Mr. Justice Jackson, October 7, 1946" in Report of Robert H. Jackson, United States Representative to the International Conference on Military Tribunals (Washington: Department of State, 1949), 435.
} 
Indeed, the only "unsettled question" at the close of the trials, Jackson indicated, was "by what method these should be tried. ${ }^{24}$

Michael Marrus has argued that the course of most atrocity trials - those centered around acts of mass violence and crimes against humanity—has been "determined by the indictments of the accused," rather than the crimes committed against the victims. ${ }^{25}$ To be sure, the statutory language used for prosecution focuses on the criminal rather than those who have been affected. Yet the distinctions between retributive and restorative aims of the IMT grow particularly muddled as we look to the laws that arose from those trial proceedings. Stephen Ratner has explained that the crime of genocide "received its first formal, legal recognition" at Nuremberg. ${ }^{26}$ Unlike most definitions in criminal law, the United Nations' definition of genocide makes the victim, rather than the perpetrator, the subject of the crime. Under Article 2 of the Convention on the Prevention and Punishment of the Crime of Genocide, it is defined as "any ... acts committed with the intent to destroy, in whole or in part, a national, ethnical, racial or religious group. ${ }^{27}$ Discussing the broad-reaching implications of the Convention, William Schabas emphasizes that genocide became one of the first internationally delineated crimes on the basis of its affect on victims. ${ }^{28}$ The Universal Declaration of Human Rights (UDHR) was ratified just one day after the Genocide Convention in December of 1948. According to

\footnotetext{
${ }^{24}$ Ibid.

${ }^{25}$ Michael Marrus, "Forward," in Atrocities on Trial: Historical Perspectives on the Politics of Prosecuting War Crimes (Lincoln: U of Nebraska Press, 2008), xi.

${ }^{26}$ Steven R. Ratner and Jason Abrams, Accountability for Human Rights Atrocities in International Law: Beyond the Nuremberg Legacy (New York: Oxford UP, 1997), 25.

${ }^{27}$ UN Doc, Article 2 of the Convention on the Prevention and Punishment of the Crime of Genocide. Notably, the resolution also has implications for domestic homicide statutes, emphasizing that "genocide is a denial of the right of existence of entire human groups, as homicide is the denial of the right to live of individual human beings." See General Assembly Resolution 96(I).

${ }^{28}$ William Schabas, Genocide in International Law: The Crime of Crimes (New York: Cambridge UP, 2000), 35.
} 
Schabas, the UDHR "laid the groundwork for the steady progress" of closing the victim-centered lacuna within pre-World War II human rights law instruments. ${ }^{29}$

I argue that our understanding of restorative justice and its relationship to world literature must begin with Nuremberg and that we might construct a new definition of the global novel that is tied irrevocably to the international legal history of the twentieth century. Michael Marrus has defined the Nuremberg trials as such a global "turning point,",30 and as Patricia Heberer and Jurgen Matthaus have contended, questions of international justice that began with Germany in 1945 "now transcend the Nuremberg case." ${ }^{31}$ Specifically, victim issues in 1945 remain relevant in contemporary culture, and we can look to imaginative literature to identify and seek remedies for wounds left unaddressed by law. Indeed, historians tend to agree that "Nuremberg" has "experienced something of a revival in the last fifteen years," particularly with the reconstitution of the criminal tribunals and the creation of the permanent International Criminal Court (ICC). According to Donald Bloxham, the implications of the Nuremberg Trials have significance in the post-cold war period "in a way that [they] did not in the interim," and indeed "meant little for decades." 'Nuremberg' as a juridical and political construct has been "invested with symbolic power" in almost all attempts to account for mass crimes at any global position. ${ }^{32}$ I acknowledge that it has become a symbol with immense significance for contemporary international criminal courts, providing a historic basis from which "more criminal from more regimes can now be tried for more crimes." At the same time, we can revisit Nuremberg as a starting point for a new approach to relations between the practices of law and literature. As Bloxham points out, "like

\footnotetext{
${ }^{29}$ Schabas, 544.

${ }^{30}$ Michael Marrus, "The Holocaust at Nuremberg," in Yad Vashem Studies 26 (1998), 5-6.

${ }^{31}$ Patricia Heberer and Jurgen Matthaus, "War Crimes Trials and the Historian," in Atrocities on Trial: Historical Perspectives on the Politics of Prosecuting War Crimes (Lincoln: U of Nebraska Press, 2008), xiii.

${ }^{32}$ Donald Bloxham, "Milestones and Mythologies: The Impact of Nuremberg," in Atrocities on Trial: Historical Perspectives on the Politics of Prosecuting War Crimes (Lincoln: U of Nebraska Press, 2008), $263-64$.
} 
all symbols, Nuremberg can be appropriated for a variety of agendas," and those need not dwell solely in the realms of historical and political discourses. ${ }^{33}$

As I have discussed, ideas concerning restorative justice were not outside the thinking behind Nuremberg and the subsequent tribunals. By 1993, the mandate of the International Criminal Tribunal for the former Yugoslavia (ICTY) focused on retribution for international human rights violations, but it also implied a distinct interest in restorative justice: "The mandate of the Tribunal is to bring to justice those responsible for serious violations of international humanitarian law committed in the former Yugoslavia since 1991 and thus contribute to the restoration and maintenance of peace in the region. ${ }^{\$ 34}$ Madoka Futamura suggests that this language does not imply an interest in reparative measures for victims at all, but rather focuses on the "removal of an immediate threat." ${ }^{35}$ In other words, retributive justice makes the perpetrator its subject, much as Marrus describes the Nuremberg indictments. The assumption here is that more stands in question than the thematic representation of a historical wound. The last sixty years have displayed a recurrent need to invent narratives that can project the after-history of judgment, narratives that can bring the problem of repair (individually and collectively) back to the center of concern. A dominant strain in contemporary fiction has assumed this burden. The global novel is inconceivable apart from the question of global human rights.

The ICTY was the first international criminal tribunal established since Nuremberg, and its aims primarily included prosecuting high-ranking perpetrators of crimes against humanity. As such, its creators identified a distinct "echo of Nuremberg" in its creation. Madeleine

\footnotetext{
${ }^{33}$ Bloxham, 277.

${ }^{34}$ ICTY Mandate, available at http://www.icty.org/sid/320 (last accessed February 5, 2014).

${ }^{35}$ Madoka Futamura, War Crimes Tribunals and Transitional Justice: The Tokyo Trial and the Nuremberg Legacy (New York: Routledge, 2008), 4.
} 
Albright said to the U.N. Security Council: "There is an echo in this chamber today. The Nuremberg principles have been reaffirmed." ${ }^{36}$ The crafters of the ICTY sought to improve upon the Nuremberg trials to create a "far different procedure than that experienced forty-eight years earlier at the Nuremberg Tribunal. ${ }^{, 37}$ David Scheffer had been tasked with "the lead American job of building five separate war crimes tribunals," beginning with infrastructure for the former Yugoslavia (3). Yet Scheffer, who was appointed by then-president Bill Clinton to serve as the first U.S. Ambassador for War Crimes Issues, omitted information about any restorative justice aims from his personal account of the tribunal and its inception. In fact, his memoir recalls others' desire to institute a "community-based form of justice . . . designed to meld punishment with reconciliation," but Scheffer reflects that it only led to his "wasting one year following well-meaning but unrealistic advice" (112). If reconciliatory practices could not practically operate within certain conception of the court, can we look to the novel to provide this necessary counterpart? Or are extra-legal truth commissions, such as those in South Africa and East Timor, sufficient to mend the gaps created in the practice of international human rights law?

The ICTY began its operation in 1995, during the same year as the Truth and Reconciliation Commission (TRC) in South Africa (Scheffer 87). The TRC, unlike the tribunal, focused on repairing the harms of apartheid in South Africa between 1948-1994. It was a "unique tripartite institution with responsibilities to prepare a record of the apartheid era, make recommendations for reparations, and grant amnesty.” In short, the TRC aimed for national

\footnotetext{
${ }^{36}$ Julia Preston, "U.N. Security Council Establishes Yugoslav War Crimes Tribunal; Judicial Panel is 1st Such Body Since Nuremberg," Washington Post, February 23, 1993, A1.

${ }^{37}$ David Scheffer, All the Missing Souls: A Personal History of the War Crimes Tribunals (Princeton: Princeton UP, 2012), 29.
} 
reform and community healing as an alternative to the aims of Nuremberg. ${ }^{38}$ While the IMT and the ICTY focused on accountability for human rights abuses, the TRC sought to expose the truth of apartheid atrocities to "promote national unity and reconciliation."39 For many legal practitioners, truth commissions operate extra-legally, as they define accountability in different terms. Indeed, international human rights lawyers have harangued the South African truth commission for its moral, rather than legal, foundations, ${ }^{40}$ while others have criticized it for failing to fulfill its goals. ${ }^{41}$ In response, the architects of the TRC emphasized the ongoing nature of restorative justice and its eye toward ongoing reconciliation. ${ }^{42}$

But do the reconciliatory aims of truth commissions actually lead to victim recovery? And can we reconcile victims' need for repair with the retributive focus of the tribunal system? Perhaps. However, the abiding cultural injuries in countries like South Africa, which have addressed rights violations through truth commissions, suggest the foundational place of narrative labor. I have shown how legal practitioners created international human rights law in response to the ruptures of World War II, yet the stark fracture between retributive and restorative justice in the courtroom has grown in subsequent decades, as the practices of the ICTY and the TRC highlight. To address the stakes of restorative justice in the contemporary imagination, I begin at the mid-century break of Nuremberg and investigate the terms of human recovery. Global narratives, I contend, presents us with a singular form through which to negotiate the possibilities for restorative justice in a larger cultural realm. For as Ravit Reichman

\footnotetext{
${ }^{38}$ Amnesty International and Human Rights Watch, "Truth and Justice, Unfinished Business in South Africa," Summary AI Index 521001/2003, February 2001.

${ }^{39}$ G. Werle, "Without Truth No Reconciliation," talk at Institut fur Kriminalwissenschaft, Berlin, May 18. 1995.

${ }^{40}$ See, for example, A. Gutmann and D. Thompson, "The Moral Foundation of Truth Commissions," April 19, 1998. Obtained from South African History Archive.

${ }^{41}$ See, for example, Tristan Anne Borer, "A Taxonomy of Victims and Perpetrators: Human Rights and Reconciliation in South Africa," in Human Rights Quarterly 25 (2003): 1088-1116; Roy L. Brooks, "What Price Reconciliation?" in When Sorry Isn't Enough: The Controversy Over Apologies and Reparations for Human Injustice, ed. Roy L. Brooks (New York: NYU Press, 1999): 443-447.

${ }^{42}$ See, for example, Alex Boraine.
} 
has emphasized, "Law is not limited to what happens in the courtroom. Its reaches run far deeper: we live in a legal world, inhabit a legal culture, even if we never come before a jury or witness a trial" (Reichman 7-8). ${ }^{43}$

\section{Critical Background}

The dissertation draws from arguments in several distinct disciplines, but argues for the convergence of these perspectives as it suggests new avenues for thinking about the terms of restorative justice. My arguments grow from but move beyond the so-called law and literature movement of the 1980s and 1990s and its many incarnations, extending its range to address such issues as the viability of literatures of political resistance; the relationship between psychoanalysis, trauma, and the novel; and the limitation of traditional legal approaches to the literary through the rubric of postcolonial studies. ${ }^{44}$ Most immediate to the project's concerns are those proposed by literary scholars working across the field of literature and the language of international human rights law.

Out of the IMT grew the discourse of international human rights, and contemporary literary scholarship reflects a renewed attention to it. A focus on the language of human rights and its limitations ushered in a new period for law and literature in the early 2000s. Joseph Slaughter discusses the ways in which literature might illuminate the humanness of the individual depicted in the UDHR. Specifically in the Bildungsroman, "the novelistic

\footnotetext{
${ }^{43}$ See also Patricia Ewick and Susan Silbey, The Common Place of Law: Stories from Everyday Life (Chicago: U of Chicago Press, 1998).

${ }^{44}$ Barbara Harlow, Resitance Literature (New York: Methuen, 1987); Shoshana Felman, The Juridical Unconscious: Trials and Traumas in the Twentieth Century (Cambridge: Harvard UP, 2002); Shoshana Felman \& Dori Laub, Testimony: Crises of Witnessing in Literature, Psychoanalysis, and History (New York: Routledge, 1992); Martha Nussbaum, Poetic Justice: The Literary Imagination and Public Life (Boston: Beacon Press, 1995); Peter Brooks, Troubling Confessions: Speaking Guilt in Law and Literature (Chicago: U of Chicago Press, 2000); Lynn Hunt, Inventing Human Rights: A History (New York: W.W. Norton \& Co., 2007); Gayatri Spivak, "Use and Abuse of Human Rights," in boundary 2: An International Journal of Literature and Culture 32:1 (2005): 131-189.
} 
declarations of rights assert to their protagonists the positive rights of the citizen that ostensibly already belong to them by natural right; that is, the Bildungsroman, explicitly or implicitly, narrates 'a right to have rights." Focusing on the nature of personhood and "becoming human," Slaughter links contemporary terms for human rights back to early conceptions of bildung in Western literary traditions and through to postcolonial and world literatures, ultimately arguing that the Bildungroman is a method through which marginalized persons construct spaces in which to make socio-literary claims to rights. ${ }^{45}$ While Slaughter imagines an alternate literary space in which the marginalized might activate their claims to rights, Wendy Brown contends that the use of such universalizing "rights" language necessarily subordinates others voices and masks invisible, alternate forms of suffering or injury. ${ }^{46}$ Acknowledging the inadequacy of rights language, Elizabeth Anker explains how fiction can illumine those limitations and can depict new models through which to make social justice claims. ${ }^{47}$ Considering the rights of victims, Ravit Reichman applies the domestic language of torts to reassess the social responsibility owed to the psychologically wounded after wartime. ${ }^{48}$ Yet these interventions do not address the limitations of the international criminal courtrooms themselves, nor do they contend with the ways in which juridical procedures might benefit from a more direct relationship with world literature.

My dissertation proposes a new telling: a literary history of restorative justice framed by the establishment and use of international human rights law, but directly connected to the legal history of the tribunal system. This story is one indebted to new interdisciplinary connections,

\footnotetext{
${ }^{45}$ Joseph Slaughter, Human Rights, Inc: The World Novel, Narrative Form, and International Law (New York: Fordham UP, 2007), 137.

${ }^{46}$ Wendy Brown, "Suffering the Paradoxes of Rights," in Left Legalism/Left Critique, ed. Wendy Brown and Janet Halley (Durham: Duke UP, 2002), 422.

${ }^{47}$ Elizabeth Anker, Fictions of Dignity: Embodying Human Rights in World Literature (Ithaca: Cornell UP, 2012).

${ }^{48}$ Ravit Reichman, The Affective Life of Law: Legal Modernism and the Literary Imagination (Stanford: Stanford UP, 2009).
} 
and the project would not be complete without a close attention to the work being done to address restorative justice and victim recovery in the fields of legal studies, history, and trauma studies.

Notably, the history of the international criminal tribunals and the establishment of international human rights law does not dovetail with the rise of restorative justice conversations in legal and criminal justice studies. My project, however, attends directly to the terms of restorative justice proposed among social scientists and seeks to bring it into conversation with literary analysis. A brief examination into the local roots of "restorative" thinking among criminal justice scholars can illumine the urgent need to make these terms salient within international cultural discussions.

The widespread use of the term "restorative justice" did not begin until the latter decades of the twentieth century, and legal commentators argue that it arose from local and domestic inconsistencies in the American criminal justice system. ${ }^{49}$ Like the international human rights terms constructed at Nuremberg, tenets of restorative justice have been codified through much of the U.S. legal system. Beginning in the 1970s and 1980s, the United States had one of the "highest rates of incarceration among developed nations," and crime rates only rose during these decades. ${ }^{50}$ During this period, no international tribunals arose; indeed, the first and only tribunal had occurred between the years of 1945-46, placing high-ranking Nazi and Japanese war criminals on trial for crimes committed during World War II.

In this intervening period, however, legal practitioners and criminal justice scholars began to question the utility of an adversarial justice system as they acknowledged that the underlying principles of restorative justice — forgiveness, healing, and restitution—had long been

\footnotetext{
${ }^{49}$ See, for example, Ross London, “A New Paradigm Arises," in A Restorative Justice Reader, ed. Gerry Johnstone (New York: Routledge, 2003): 5.

${ }^{50}$ Ibid.
} 
part and parcel of international models of justice. My project picks up on the global foundations of restorative justice, linking it more closely to international human rights matters in the courtroom and in the study of world literature. Indeed, Howard Zehr and John Braithwaite have emphasized that elements of healing and repair cross cultural and spatial boundaries in the practice of what they term "community justice." ${ }^{51}$ Accordingly, Braithwaite argues that restorative justice models might be able to transcend cultural difference, allowing us to move beyond a pejorative conception of universality; the term might apply to international justice without excluding previously marginalized groups. ${ }^{52}$ Given that these alternatives to punitive juridical sanctions can be traced historically, critics of the domestic criminal justice system in the United States developed "restorative justice" as a new paradigm that could take into account victim needs in the aftermath of crime, and could make victims "more than just evidence" in criminal justice proceedings. ${ }^{53}$

For some critics like Zehr, the problem with retributive justice is that it relies on definitions of crime that exclude the victim altogether. ${ }^{54}$ Similar to historians like Marrus who have assessed the efficacy of the Nuremberg Trials, Zehr stresses the problematic statutory and linguistic focus on the criminal rather than on the object of the crime itself. However, Zehr's approach relies on readings of domestic law, sidestepping the victim-centered language of both the UDHR and the Genocide Convention. In short, international human rights law provides specific language of restorative justice within a retributive system, and my work seeks to address those reparative aims in both legal practice and the global novel.

\footnotetext{
${ }^{51}$ Howard Zehr, 23.

52 John Brathwaite, 62.

${ }^{53}$ Ross London, 6.

${ }^{54}$ Zehr explains that "[t]he definition of crime . . . excludes crime victims" (25).
} 
The problem of focusing on the perpetrator is not limited to statutory language, however, and thus cannot be answered entirely by the sheer presence of international human rights law. Aside from the logistical problems of putting reparative goals into legal practice, Margaret Urban Walker emphasizes that we need to shift the very focus of our thinking about justice from the criminal onto the victim. ${ }^{55}$ She exposes a larger problem of the imagination rather than one of language alone. Highlighting this issue, Martha Minow advises that, even if measures of justice are to involve the perpetrator, the conceptual focus must lie with the victim. She emphasizes the need for "building connections and enhancing communication between perpetrators and those they victimized, and forging ties across the community." ${ }^{, 56}$ The novel can centralize a victim narrative, but such a claim is not new to scholarship in law and literature. ${ }^{57}$ Rather, world literature as I conceive it can invent new terms and models for victim recovery, speaking directly to the limitations faced by any juridical body tasked with large-scale prosecution of crimes against humanity. To be sure, the project moves beyond superficial claims about the imaginative capacities of literature in the face of the limited potential of the law. The claim here is not that literature does better than law; the project tackles matters of repair to which we cannot reasonably hold legal practice.

A notable problem within legal praxis that can be readily answered by literature is the alleged "amorphousness" of restorative justice among thinkers across disciplinary bounds. To whom does the term apply? And does it have the same definition in all contexts? Here, we can locate one of the central tools of world literature. In the novel, we can conceive new and distinct definitions of victim recovery that take into account specific moments of geopolitical violence,

\footnotetext{
${ }^{55}$ Margaret Urban Walker, "Restorative Justice and Reparations," in A Restorative Justice Reader, ed. Gerry Johnstone (New York: Routledge, 2003): 174.

${ }^{56}$ Martha Minow, Between Vengeance and Forgiveness: Facing History After Genocide and Mass Violence (Boston: Beacon Press, 1998): 92.

${ }^{57}$ See Julie Stone Peters for a discussion of the previous trends in law and literature.
} 
and we can carry the possibilities for repair from the courtroom and out into the broader realm of global culture. By its nature, the law relies on set definitions of crime. The novel, in contrast, can produce culturally specific imaginaries surrounding political violence.

According to Ross London, the term "restorative justice" wants to be all-inclusive and thus suffers from a dangerous universalizing impulse. ${ }^{58}$ Indeed, Judge Richard J. Goldstone discusses victimhood in these dangerous terms as he explains that "massive violence—in South Africa, the former Yugoslavia, and Rwanda ... are situations [that] are universal and one must recognize that any people anywhere have the potential for evil on a massive scale, and that all victims, whoever they may be, need the opportunity to heal. No continent, no region, and no people are immune from it."

The issues at stake are thus multiple and varied. How do we define restorative justice? And if we acknowledge that it has differing definitions with boundaries that are not easily drawn, can literature more fully articulate terms of victimhood and recovery?

Despite these striking lacunae in the discourse of criminal justice, questions of restoration have become prominent in the work of modern historians who focus on the recent and unprecedented attention to victimhood after World War II. A recent concern in trauma studies, as Carolyn J. Dean points out, is that there is "too much interest in victims, in part perhaps because it tends to conflate victims of all sorts with the more specific kinds of victimization identified with the extreme violence generated by torture, war, and catastrophic loss" (5). To be sure, Dean argues, trauma has "come to define identity in our wound culture" (6). Echoing Dean's concerns, Peter E. Gordon suggests that "suffering ... has been fetishized, then

\footnotetext{
${ }^{58}$ London, 8 .

${ }^{59}$ Richard J. Goldstone, "Forward," in Between Vengeance and Forgiveness (Boston: Beacon Press, 1998): iv. Goldstone served as one of the first judges on the Constitutional Court of the free South Africa, and as a former Chief Prosecutor at the International Criminal Tribunal for the former Yugoslavia and at the International Criminal Tribunal for Rwanda.
} 
instrumentalized, and finally displaced by the simulacrum," as "post-Holocaust culture has entered upon an era of traumatic excess-an apotheosis of a victim whose moral stature has gown so exorbitant that no representation can ever be adequate and no reparation can suffice." ${ }^{\$ 0}$ Their concerns are not anomalous, and they might reflect the need for a new approach to repairing the mid-century wounds that remain in the present—-for survivors but also in the public memory.

Indeed, a vast literature surrounding victimhood exists in the disciplines of history and politics, ${ }^{61}$ but it does not yet account for the specific limitations within the criminal tribunal system. As a response to the opposing problems of "too much enshrinement of victimhood or insufficient memorializing of victims and survivors" in legal discourse, ${ }^{62}$ I suggest that we turn to modern and contemporary global literature. The novel, I contend, can provide distinct images of restoration that speak directly to juridical omissions, and thus align within the historical framework of the international criminal tribunal system. As such, we might employ literature to rethink both the retributive and restorative makings of justice. How can the global novel teach us about the power of reading practices in conceiving of restorative justice? To answer this question, we might look to a novel that contends directly with the literary echoes of Nuremberg and the accompanying possibilities for repair.

\footnotetext{
${ }^{60}$ Peter E. Gordon, "Review," in Aversion and Erasure: The Fate of the Victim After the Holocaust (Ithaca: Cornell UP, 2010).

${ }^{61}$ See, for example, Kris Brown, "Historical Justice in International Perspective: How Societies are Trying to Right the Wrongs of the Past," in Perspectives on Politics 8 (2010): 965-968; Istvan Deak, Jan T. Gross, and Tony Judt, The Politics of Retribution in Europe: World War II and its Aftermath (Princeton: Princeton UP, 2000); Lyndsey Stonebridge, The Judicial Imagination: Writing After Nuremberg (Edinburgh: Edinburgh UP, 2011); Ernesto Verdeja, Unchopping a Tree: Reconciliation in the Aftermath of Political Violence (Philadelphia: Temple UP, 2009); Zoe Vania Waxman, Writing the Holocaust: Identity, Testimony, Representation (New York: Oxford UP, 2007).

${ }^{62}$ Minow, 2.
} 


\section{W.G. Sebald's Austerlitz: A Literary Return to Nuremberg}

The history I attend to is a legal one that illumines key moments in the twentieth century, yet these events have also been salient turning points in literature. For many critics, World War II represents a break between modernism and postmodernism. Indeed, Theodor Adorno's dictum that "to write poetry after Auschwitz is barbaric" suggests a deep concern with the ability for literary form to contend with the horrors of modernity. ${ }^{63}$ Yet I suggest that we need to reconsider the connections between the legal events in the aftermath of World War II and their relationship to imaginative inquiry. Throughout the second half of the twentieth century, novelists have returned to the moment of 1945 and the omissions of the IMT. In addition to novels that fit neatly into categories of Holocaust memoir or German-Jewish literature, there is larger body of Anglophone work that implies the global impact of Nuremberg. For example, Kazuo Ishiguro's A Pale View of Hills (1982) reinscribes the injuries of the 1945 atomic bomb in Nagasaki upon an English-speaking readership in the early 1980s. Ishiguro's protagonist, a woman in postwar Nagasaki, recalls in flashback form the attempt to reconstruct her life in the aftermath of the atomic bomb. Art Spiegelman literally draws his parents' history of the Holocaust into being nearly fifty years later through his graphic novel Maus (1992). Anne Michaels' Fugitive Pieces (1998) illumines the process of excavation that a child Holocaust victim must enact. More than other novels, however, W.G. Sebald's Austerlitz (2001) reclaims a distinct victimhood omitted from the tribunal that speaks directly to matters of international justice. Why do we need to continue addressing the omissions at Nuremberg? Given that the IMT represented the foundation upon which more recent international tribunals have been modeled, its fractures and failures remain salient in contemporary culture. The global novel, a

\footnotetext{
${ }^{63}$ See Theodor Adorno, Prisms (Cambridge: MIT UP, 1997).
} 
category shaped through works like Sebald's, might provide grounds on which to excavate an unfinished past and to account for its losses.

As James Wood has argued, "Sebald was always asking us to reflect on how we access the past, how we rescue the dead, and how the writer performs that real, but necessarily fictional, reclamation." ${ }^{, 64}$ In basic terms, Sebald's work responds directly to lapses at the IMT. As Justice Jackson recorded in his Nuremberg journal on May 7, 1945, “despite the large talk, there has been little done to really dig out evidence." There is still something to learn from a return to the moment of 1945 about the reflected in works of imaginative literature. Each constructs a narrative that relies on pivotal moments of recovery and rehabilitation that relate back to World War II, the omission of victims at the IMT, and the nature of justice.

A brief glimpse into the writing and reception history of Austerlitz suggests that it might stand as a quintessential piece of world literature. Sebald was born in Germany but resided in Britain for most of his life. He wrote his novels in German but was fluent in English, and often explained that he wrote with the understanding that his books would appear for a broader audience in English translation. In fact, "it was clear that he worked over the English so that is amounted almost to a collaboration with his translator."65 To be sure, he had written many poems in English, and Anthea Bell, the translator of Austerlitz and other of Sebald's works, exclaimed that "so wide was Max's knowledge of English that I was disproportionately pleased when I could introduce him to anything he didn't know already."66 The English and German editions of Austerlitz both appeared in 2001, at which time Sebald had been deemed an international writer by literary critics (Blackler 84-85). Literary scholars like Mark McCulloh and Lilian Furst have discussed Sebald's novels as being distinctly outside the realm of European

\footnotetext{
${ }^{64}$ James Wood, “W.G. Sebald: Reveries of a Solitary Walker,” in The Guardian, April 19, 2013.

${ }^{65}$ Ibid.

${ }^{66}$ Deane Blackler, Reading W.G. Sebald: Adventure and Disobedience (London: Camden House, 2007$), 83$.
} 
literature, moving instead into an amorphous realm of the global. ${ }^{67}$ Indeed, Robert Macfarlane explains that "one never knows how to classify his books," since they appear in "no known genre, no known language." ${ }^{68}$ Unsurprisingly, Sebald himself insisted upon giving readings of his works in English, especially in non-English-speaking venues. For instance, he would read and interview in English while in Amsterdam and Germany, and he read from both the German and English editions of his works while in London (Blackler 90). Iain Sinclair once described the writer as "more English than the English." ${ }^{69}$ By October 2001, the English edition—rather than the German — of Austerlitz had been distributed internationally on four different continents (Blackler 91). Sebald's literature thus introduces us to a new terminology for the global novel that transcends national borders and aims toward readings in and out of translation. With such a conception of world literature, we might understand Sebald's novel as an urgent plea with regard to international law. Specifically, Austerlitz asks its reader to exhume the unfinished juridical pasts of WWII and Nuremberg.

Similar to Sebald's other novels, Austerlitz defies narrative conventions with its alinear story interspersed with photographic and other images. Inasmuch as the novel might be said to have a plot, an unnamed first-person narrator recounts his own visits to concentration camp sites in a frame narrative. In between, the narrator depicts his interactions with a Czech Jewish refugee named Jacques Austerlitz in present-day London. Austerlitz had been a child on the Kindertransport rescue mission, covertly placed in a Welsh foster home at the outbreak of World War II in Europe. Near the beginning of the novel, we learn that the adult Austerlitz has experienced a deep sense of displacement and loss in the modern world. He has no knowledge of his familial history in Czechoslovakia, and any remnants of his native tongue have perished;

\footnotetext{
${ }^{67}$ See W.G. Sebald: Works \& Influences March 13-16, 2003, Davidson College, Davidson, NC.

${ }^{68}$ Robert Macfarlane, "W.G. Sebald: Reveries of a Solitary Walker," in The Guardian, April 19, 2013.

${ }^{69}$ Iain Sinclair, "W.G. Sebald: Reveries of a Solitary Walker," in The Guardian, April 19, 2013.
} 
he speaks only English. As the narrative progresses, Austerlitz returns to Eastern Europe and begins to uncover information about his mother and her death in the Holocaust. During the process, he remembers fragments of Czech language and eventually leaves the narrator with a promise to continue seeking out information about his father's French Jewish background.

In many respects, Austerlitz is a novel about excavations of the past. Through its fragmentary and atemporal narrative, it requires a dedicated reader willing to mine the text for evidence of a story. Sebald himself has extracted (and collected) aesthetic histories to create the book, selecting anonymous photographs and images that come together in the German and English language publications of Austerlitz. Returning to the moment of 1945 from a contemporary vantage point, Sebald's novel at first appears to fall within the trap that Andreas Huyssen sets for all postmodern literature. Post-Holocaust aesthetic representations tend toward categories of forgetting or memorializing, he suggests - a stark binary that suggests we have all been traumatized by the Nazi regime and choose either to repress that trauma or to contend with it saliently. ${ }^{70}$ But what if the cultural memory of World War II also points to the lacunae inherent in the criminal prosecutions of the period? Can the post-1945 "ghosts of the Fatherland" be juridical in nature? Indeed, a different kind of historical reading of Austerlitz suggests that a "laying to rest the ghosts of the past" necessarily includes those of the trials that set out to prosecute high-ranking Nazis for crimes against humanity. ${ }^{71}$

The novel starkly criticizes the reparative limitations of the trials at a moment in presentday Nuremberg. For a Czech Holocaust victim like Austerlitz, the German city remains unknowable: "Around midday we reached Nuremberg, and when I saw the name on a signal box

\footnotetext{
${ }^{70}$ Andreas Huyssen, Twilight Memories: Marking Time in a Culture of Amnesia (New York: Routledge, 1995), 209-210. See also Huyssen, Present Pasts: Urban Palimpsests and the Politics of Memory (Stanford: Stanford UP, 2003).

${ }^{71}$ Huyssen, Twilight Memories, 210.
} 
in its German spelling of Nürnberg, which was unfamiliar to me" (222). ${ }^{72}$ Once a symbolic center of the Nazi Party and later reclaimed as a site of postwar justice, Nuremberg produces only anxiety in Austerlitz, who "felt more panic-stricken with every passing minute" and "had to stop under the red sandstone arch of a window displaying the pages of the local Nuremberg newspaper" (224). An older Nuremberg resident stops to give a form of reparation, as if to account for its absence in the city where the trials took place. Austerlitz explains how an elderly woman "fetched a one-mark coin out of her purse with arthritic fingers, and carefully handed it to me as alms." The coin, Austerlitz emphasizes, was "minted in 1956 with the head of Chancellor Adenauer on it" (224). A small yet significant detail, as the first chancellor of the FRG, Konrad Adenauer historically is credited with instituting terms for victim recovery in postwar Germany. Specifically, Adenauer “offered his nation's apologies for Nazi atrocities and committed Germany's resources to make amends with survivors and the international community." ${ }^{, 73}$ He also inaugurated the use of monetary reparations, or restitution, for Holocaust victims. $^{74}$

Like Nuremberg in contemporary cultural memory, traces of the past creep into the present in Sebald's novel, begging questions about recent juridical history: what did we miss at Nuremberg, and what do we continue to get wrong in current incarnations of international human rights law? The IMT failed to attend to the individual needs of victims, even to give voice to those victims at the trials. The novel, alternately, might provide a new method to account for

\footnotetext{
72 The original German reads: "Gegen Mittag erreichten wir Nürnberg und wie ich diesen Namen in der mir unvertrauten deutschen Schreibweise an einem Stellwerk sah ..." (321). Notably, the different spellings of Nürnberg and Nuremberg are absent in the German version, making the English translation more intelligible to those beyond Germany — only outside Germany do we see "Nuremberg" in lieu of "Nürnberg."

${ }^{73}$ Hubert Kim, "German Reparations: Institutionalized Insufficiency," in When Sorry Isn't Enough: The Controversy Over Apologies and Reparations for Human Injustice, ed. Roy L. Brooks (New York: NYU Press, 1999), 78.

${ }^{74}$ Ronald Zweig, German Reparations and the Jewish World: A History of the Claims Conference (Portland: Frank Cass Publishers, 2001), 61.
} 
victim trauma and rehabilitation. After all, as Arthur Williams points out, Sebald thought of himself as "a committed teacher" through his literature, ${ }^{75}$ and Deane Blackler has argued that "Sebald's belief in the power of education, and reading, to civilize underpins his enterprise, even as he records the trauma of our decivilizing, self-destructive impulse to destroy the cities that we have created" (86). Sebald suggests to us that sites of cultural memory have been offered in response to these legal omissions.

Literature discussing the "museumification" of the Holocaust is broad and far-reaching. A full analysis of its cultural efficacy would be misplaced in this discussion, but it is important to acknowledge, for purposes of my reading of Austerlitz, that many of the Holocaust museums and memorials that have arisen in recent decades appear as extra-legal, victim-centered offerings. Indeed, they represent exactly the kind of victim mania that Carolyn J. Dean critiques in historical accounts of the second half of the twentieth century. For example, the Nazi Party rally grounds in Nuremberg exist on a site that had been abandoned for decades since the end of WWII - a real-life Sebaldian landscape. The space recently was repurposed as a museum with a guided narration that frames the victims of the Third Reich as the subjects in this space.

According to its curators, the rally grounds are a site for both Germans and global citizens to consider the wounds of the Nazi regime. ${ }^{76}$ Holocaust museums across the world—from Washington, D.C. to Berlin to Sydney—display objects that point to these wounds, bringing them into existence for a new generation and thus attempting to keep alive victim narratives. As Walter Benjamin has argued, the "true method of making things present is to represent them in our space." ${ }^{, 77}$ Dean specifically has described the Yad Vashem museum, the Berlin memorial,

\footnotetext{
${ }^{75}$ Arthur Williams, "W.G. Sebald: A Holistic Approach to Borders, Texts and Perspectives," in German-Language Literature Today: International and Popular?, 99.

${ }^{76}$ See Christmeier interview.

${ }^{77}$ Walter Benjamin, The Arcades Project, ed. Rolf Tiedemann (Cambridge: Harvard UP, 1999), 206.
} 
and the global Holocaust museum sites as ones that "all draw heavily on the victim's voice and testimony."78

Yet Sebald's writing suggests dissatisfaction with the proliferation of museums and monuments to fill the voids of Nuremberg. Indeed, they merely become symptomatic of the "popularity" of victimhood in sociological and historical discourses. ${ }^{79}$ Sebald even equates their omissions to juridical ones, describing the "tendency towards monumentalism evident in law courts and penal institutions" (33). While museums and memorial sites surely offer certain models for contending with mass violence and its long-lasting social effects, can imaginative literature depict new methods for victim recovery that more closely attend to the omissions of international jurisprudence? Museum and memorial sites cannot fully account for victim trauma as they cannot serve as restorative counterparts to the retributive focus of international tribunals. Since museum sites and memorials represent the primary mode of addressing victimhood in contemporary culture, Sebald's novel suggests that we need to start here in order to reposition global narrative as providing more viable options for thinking about victimhood and repair in relation to juridical concerns. For museums have proliferated not simply in response to the harms of WWII but in fact to those throughout the twentieth century, particularly in response to the traumas in the former Yugoslavia and in South Africa during apartheid. ${ }^{80}$ James Young describes one of the problems with "museumifying" to restore the injuries of political violence that remain unaddressed through the law. Referring to Bergen-Belsen, he explains,

Except for what is shown in a tastefully refurbished documentation center of stone and glass, little of what transpired specifically at Bergen-Belsen is reflected in the outdoor memorial space. Instead, as if harking back to the grisly film footage by which Bergen-

\footnotetext{
${ }^{78}$ Carolyn J. Dean, Aversion and Erasure: The Fate of the Victim After the Holocaust (Ithaca: Cornell UP, 2010$), 6$.

${ }^{79}$ Carolyn J. Dean describes the problematic "popularity" of the victim in post-Holocaust representations of trauma (6).

${ }^{80}$ See, for example, the historical museum in Sarajevo; Walter Sisilu Square in Soweto; or the Apartheid Museum in Johannesburg.
} 
Belsen is most commonly recalled, the principal motif is the prisoners' deaths and mass graves. Grouped in rows of burial mounds, each grave is marked by a small stone-andmortar façade, inscribed with the number of dead it contains: "Here rest 5,000 dead," or 2,000 dead, or 1,000 dead. $^{81}$

In Austerlitz, Sebald articulates the unsustainability of the museum space. His narrator

describes how one man's attempt to create a museum ended with destruction:

There was some kinds of cabinet of natural curiosities in almost every room at Andromeda lodge: cases with multiple drawers, some of them glass-fronted, where the roundish eggs of parrots were arranged in their hundreds; collections of shells, minerals, beetles, and butterflies; slowworms, adders, and lizards preserved in formaldehyde; snail shells and sea urchins, crabs and shrimps, and large herbaria containing leaves, flowers, and grasses .... The transformation of Andromeda Lodge into a kind of natural history museum had begun in 1869 (83).

Yet the artificiality of the museum proves unmanageable, for "barely half a century later, those glories [once collected in the museum] had been almost entirely destroyed by our passion for collecting . .." (90) ${ }^{82}$ Indeed, there is no process by which to preserve some of the moths in the collection; in close proximity to other objects, they eventually turn to dust (90). Sebald turns a passion for collecting (the German Sammelleidenschaft) into a pejorative here, highlighting limitations to even the most comprehensive "museumification" efforts. In so doing, Sebald proposes an alternate literary method to account for restoration and the memory of victims in the face of juridical omissions.

\footnotetext{
${ }^{81}$ James E. Young, The Texture of Memory: Holocaust Memorials and Meaning (New Haven: Yale UP, 1993), 56. See also Ruth Klüger, Still Alive: A Holocaust Girlhood Remembered (New York: Feminist Press at CUNY, 2003). Klüger, a Holocaust survivor, noted in her autobiography that " $[t]$ he various Shoah museums and reconstituted concentration camp sites ... don't take you in, they spit you out. Moreover, they tell you what you ought to think . . .. They impede the critical faculty (198). Conceptual art criticism contends that scale is the key to a meaningful interaction with an architectural structure and must be limited, roughly, to the size of a human being in order to take on anthropomorphic qualities essential to a testimonial encounter. Minimal artist Tony Smith's discussion of his famous work Die, largely considered to have true anthropomorphic qualities, describes perfectly the importance of scale in creating structures in or around which a spectator can have a human interaction: "Q: Why didn't you make it larger so that it would loom over the observer? A: I was not making a monument. Q: Then why didn't you make it smaller so that the observer could see over the top? A: I was not making an object." Colpitt, 77.

${ }^{82}$ The original German reads: "kaum ein halbes Jahrhundert spaeter, sei diese Pracht durch unsere Sammelleidenschaft und andere, gar nicht waegbare Stoerungen und Einfluesse nahezu voellig vernichtet" (135). W.G. Sebald, Austerlitz (Muenchen: Carl Hanser Verlag, 2001).
} 
Museums cannot sufficiently collect a history of victimhood as a counterpart to retributive legal measures, and the sites of violence themselves cannot acknowledge it. Sebald's novel is filled with images of decay—of objects, structures, landscapes, and even personsreminding us that structures are subject to the "natural history of destruction," as the author has called it. ${ }^{83}$ Thus these buildings cannot be relied upon to properly attend to the harms of the past; like the Andromeda lodge cabinet of curiosities in Austerlitz, the attempt to maintain a memorial results only in its decay. Yet at the same time, the decay reminds us that this past exists - only by failing to attend to the properties of time can these physical conditions arise. In this way, the museum sites do serve a social purpose, but it falls outside the purview of restorative justice. Peter Fritzche has described such images of structural decay as the "lustre of the past." ${ }^{84}$ The present is haunted by the absence of victim participation in the meaning-making surrounding World War II memory. Austerlitz provides us with an opportunity to excavate this past that we recognize through degradation. In so doing, Sebald models how imaginative literature gives us the opportunity to reimagine possibilities for reclamation that stem from 1945 but do not rely on the Holocaust and the trials at Nuremberg as the only points of reference; to be sure, he offers us a way of reading that encourages the excavation of violent pasts buried within the overlapping political injuries of modernity. And literary images of natural decay act as constant reminders of this - moments of past violence indelibly in the present.

Sebald brings his reader to memorialized sites of violence, explaining how their palimpsestic nature limits knowledge of specific crimes; we cannot attend to victim recovery at these places. Rather, the sites create nebulous categories of victimhood. Austerlitz opens with the narrator's visit to the Belgian fortress of Breendonk. Our textual introduction to the fortress

\footnotetext{
${ }^{83}$ Sebald, On the Natural History of Destruction (New York: Random House, 2003).

${ }^{84}$ Peter Fritzche, "Sebald's Twentieth-Century Histories," in W.G. Sebald: History, Memory, Trauma, eds. Scott D. Denham, Mark Richard McCulloh, and Walter de Gruyter (Urbana: Illinois UP, 2006).
} 
begins with contemporary photographs of the site, including a long-shot encasing the entire structure, as well as close-up shots and blueprint maps (20-21). Without accompanying narration, the reader is forced into a difficult position in which she cannot parse the image. In an actual visit to Breendonk, the "museum" provides each visitor with a handheld guide for various points inside the fortress. ${ }^{85}$ As such, the exterior photographs of the site that appear in Austerlitz provide no less information than a memorial pilgrimage to the fortress itself. For outside the structure where Sebald's narrator stands, there exists a stark disconnect between what we seemonumental blackened stone fortress walls that bear marks of decades well beyond the twentieth century—and the information that the guide language has imparted about the Belgian government's attempt to preserve the site as a Holocaust memorial. Given the gap between visual and linguistic perception, we understand that the structure's ability to account for specific victimhood is limited by its many years of use by distinct regimes. Indeed, its palimpsestic nature threatens to eradicate its human history altogether. Sebald's narrator tells us:

From whatever viewpoint I tried to form a picture of the complex I could make out no architectural plan, for its projections and indentations kept shifting, so far exceeding my comprehension that in the end I found myself unable to connect it with anything shaped by human civilization, or even with the silent relics of our prehistory and early history. And the longer I looked at it, the more often it forced me, as I felt, to lower my eyes, the less comprehensible it seemed to become ... the fort was a monolithic, monstrous incarnation of ugliness and blind violence (20-21).

What happened at Breendonk? The Nazis used Breendonk as a site of incarceration primarily for political prisoners in the 1940s, but its history actually began in 1859 when it was constructed as a national fort, and later used for various purposes during the intervening years. ${ }^{86}$ Yet Sebald

\footnotetext{
${ }^{85}$ Information obtained during my own visit in July 2012.

${ }^{86}$ Sebald begins with the historical 1832 siege of Antwerp and Belgium's subsequent obsession with fortification: In 1859, accordingly, the old citadel and most of the outer forts were leveled and work began on the construction of a new enceinte ten miles long, with eight forts situated over half an hour's march away from it .... The last link in the chain was the fortress of Breendonk . . . a fort completed just before the outbreak of the First World War in which, within a few months, it proved completely useless for the defense of the city and the country (Austerlitz 17-18).
} 
contends that we cannot tell by visiting —or looking at—-this memorial site; the flattened, twodimensional photographs, absent of victim traces, represents the best scenario for memorialization and recovery.

Breendonk is now a "memorial" recovered by the Belgian government: "Between September 1940 and September 1944, around 3500 prisoners passed through Breendonk ... On [A]ugust 19th 1947 was promulgated a Bill passed by the Belgian Parliament, which allowed the creation of the Memorial of Breendonk. According to the law, the prime objective of the institution is to preserve the place with its buildings and its contents as a reminder of what happened here. ${ }^{\Perp 87}$ The language attempts to acknowledge the political victims of the Nazi regime, but Sebald explains that victims ultimately cease to exist within the structure. How can we reconcile this kind of cultural attention to victimhood at such a site with the victim-centered omissions at Nuremberg? The memorial does not function in response to the juridical gaps in restorative justice. Instead, sites like Breendonk call out for a new form through which to conceive victim repair. Walking through the fort, the narrator in Austerlitz notes, "I could not imagine how the prisoners, very few of whom had probably ever done hard physical labor before their arrest and internment, could have pushed these barrows full of heavy detritus over the sunbaked clay of the ground" (22). In fact, "it was impossible to picture them" (22). For, as the narrator emphasizes, "the history of countless places and objects which themselves have no power of memory" (24). Like the moths at Andromeda Lodge, even the objects contained as museum pieces within the spaces elude human recovery. "Histories," the narrator details, "like

Sebald then explains the truly palimpsestic nature of Breendonk, describing its use and re-use in the 1940s:

[T] he fortress of Breendonk, from which it emerged in 1940, when for the second time in its history the fort had to be surrendered to the Germans, it was made into a reception and penal camp which remained in existence until August 1944, and that since 1947, preserved unchanged as far as possible, it had been a national memorial and a museum of the Belgian resistance (19).

${ }^{87}$ See official website for the Breendonk Memorial, available at http://www.breendonk.be/EN/index.html (last visited Feb. 4, 2014). 
those of the straw mattresses [at Breendonk] which lay, shadow-like, on the stacked plank beds .

. become thinner and shorter because the chaff in them disintegrated over the years" (24).

Failures of knowledge and imagination pervade the site and others like it.

Sebald underscores these features of the museum site as the narrative shifts to Jacques

Austerlitz. When Austerlitz travels to Terezin — another former concentration camp site near

Prague - he finds no evidence that the small town once was known by its German name,

Theresienstadt. For Holocaust victims, the name "Theresienstadt," written in the German, conjures images much different from those that arise when the town has returned to its Czech pronunciation. ${ }^{88}$ His perception of the site as "an ordinary town again" disrupts official attempts to turn the site into a place for recovery through remembrance. The Czech national website for Terezín describes the memorialization of the site, explaining, "the key mission of the Terezín Memorial, the only institution of its kind in the Czech Republic, is to commemorate the victims of the Nazi political and racial persecution during the occupation of the Czech lands in World War II." 89 But at the "so-called Ghetto museum," as Austerlitz describes it, the character finds himself bombarded with the impenetrable, multiple histories contained at the site: "And whenever I think of the museum in Terezin now, said Austerlitz, I see the framed ground plan of the star-shaped fortifications, color-washed in soft tones of gray-brown for Maria Theresia, her Imperial Highness in Vienna who had commissioned it" (199). Like Breendonk, Terezin had been a nineteenth-century fortress that housed prisoners from different regimes over the centuries. ${ }^{90}$ Given the palimpsestic nature of the site, it is not surprising that Austerlitz "could not imagine who might inhabit . . these desolate buildings" as he acknowledges that Czech

\footnotetext{
${ }^{88}$ See Ruth Klueger for a description of the suffering at Theresienstadt.

${ }^{89}$ See official website for the Terezín Memorial, available at http://www.pamatnikTerezín.cz/showdoc.do?docid=164 (last visited Feb. 3, 2014).

${ }^{90}$ See Sebald, Austerlitz, 200.
} 
victims of the Nazi regime "were still living crammed into those buildings and basements and attics" (200). Memorials produce certain failures of the imagination. The tribunals, as I have shown, conceived of restorative justice but could not place it in practice. As such, an appropriate counterpart to the retributive focus of the international criminal trials must be one that produces new, imaginative models of recovery.

Images of Breendonk and Terezin highlight how, according to Young, "memorials can supplant the events they commemorate, even as they embody the gulf of time between past and present .... With so little visible evidence of its past, the memorial threatens to float atemporally above its own history. ${ }^{91}$ Sebald suggests that sites repurposed into museums do not bear significant differences from other criminal sites whose histories have not been officially memorialized. The novel shows us the Šporkova district of Prague, where both the Petschek Palace and the Trade Fair Palace, once centers of culture, were turned into centers of Nazi torture and then returned, again, to their original use such that the Nazi era became unrecognizable. Austerlitz refers to the use of "an unheated exhibition hall" in the Fair Trade Palace as a holding center for Czech Jews being deported (179), and then to the Petschek Palace: "It was only later that I realized ... the invisible terrors beneath which the city of Prague lay cowering at the time, only when I learned of the true extent of the perversion of the law under the Germans, the acts of violence they committed daily in the basement of the Petschek Palace" (175).

The novel invites us to excavate the history of these sites only to thwart the very possibility, and thereby prove the need for an alternate model of restorative justice. Photographs of Breendonk and Terezin that appear in the novel have been flattened; as readers, we have no

\footnotetext{
${ }^{91}$ See Young, referring to Dachau (60). He explains: "Immediately after the war, the Americans turned Dachau into a military stockade, where they interned SS officers awaiting trial for war crimes. By converting the camp's administrative headquarters into a courthouse, the Americans literally housed these trials within the space of evidence itself" (61).
} 
access to their histories. Rather, we can only perform the allegedly reconciliatory visits to these sites, which are modeled for us in the text through the narrator's and Austerlitz's travels. The sheer act of performance highlights the stark disruptions between the victim-centered aims of memorial sites and human response to them; opportunities for healing have been buried in the multifaceted histories of the spaces and the objects within them. As such, these museums cannot look ahead to a reparative future, as restorative justice aims intend.

Sebald underscores this point at a moment in Austerlitz that takes place in London. In certain locations of violence, "space becomes too cramped," the narrator explains, and "the dead, like the living, move out into less densely populated districts where they can rest at a decent distance from one another" (130). Yet, the narrator continues, sites of criminality never are singular or marked by a single geopolitical moment. Instead, the dead "keep coming, a neverending succession of them, and in the end, when the space is entirely occupied, graves are dug through existing graves to accommodate them, until all the bones in the cemetery lie jumbled up together" (130). We cannot visually parse these sites that beg for metaphorical excavation. Sebald provides us with an opportunity to try this on the following page, with a large-scale image of half-buried skulls. The reader cannot discern their identities or histories, and access to this "site" offers nothing but proof of death; victim specificities remain unknowable. The reader cannot excavate the photograph, but neither can the narrator the site.

If the palimpsestic nature of museum sites denies healing to victims, how can Austerlitz help us to understand the relationship between the global novel and restorative justice? While international tribunals focus on justice as retribution and victim-centered memorials inadequately address human recovery, Austerlitz suggests that the reader can play a crucial role in excavating specific victim(hoods), working to piece together the losses of individual personhood in the wake 
of political violence. In the novel, Austerlitz's personal history is marked by injury. His traumas are multiple as they reflect those experienced by Jewish children on the Kindertransport, Czech victims of the Holocaust, and emigrants generally. Yet Austerlitz's wounds are also distinct to his person as they allow us to map out the specific course of his forced migration. On a superficial level, Austerlitz has lost markers of the self-his homeland and his name.

The narrator models a process of literary excavation, first recovering Austerlitz's birth name and place. Most saliently, growing up in Wales with an adopted family and identity, Austerlitz was known as Dafydd Elias. Pressing Austerlitz, the narrator brings forth a memory: At Austerlitz's school in Wales, the headmaster informed him that "it was his duty to tell me that I must put not Dafydd Elias but Jacques Austerlitz on my exam papers. It appears, said PenrithSmith, that this is your real name" (67). Austerlitz admits that he "could connect no ideas at all with the word Austerlitz," which pushes the narrator through historical references to the name, including a Napoleonic victory, the Parisian train station, and even Fred Astaire, whose birth name was Frederick Austerlitz (67-70). Unable to contend with the limited knowledge of his past and victimhood, Austerlitz tells the narrator, "I gathered up all my papers, bundled or loose, my notepads and exercise books, my files and lecture notes, anything with my writing on it, and carried the entire collection out of the house to the far end of the garden, where I threw it on the compost heap and buried it under layers of rotted leaves and spadefuls of earth" (124-25). He describes the act as a "work of destruction" that he later regrets, as he begins to feel "a kind of heartache which, as I was beginning to sense, was caused by the vortex of past time" $(126,129)$. After burial, the narrator begins to guide us through an unearthing of Austerlitz's past and thus a reclamation of his personhood. 
Austerlitz's identity is buried in the pages of the novel rather than in the museums dedicated to his victimhood. The narrator depicts Austerlitz's reclamation of the self, making it knowable to the reader. Sebald positions the reader in the role of detective, uncovering clues to a lost past. We begin at a London train station, where women saliently speak an unrecognizable language (138). This brief image carries little weight until the narrator subsequently encounters fragments of this language again just before he hears "two women talking to each other about the summer of 1939, when they were children and had been sent to England on a special transport" (141). Through mention of a "ferry Prague to cross the North Sea to Harwich," the aural image foreshadows a return to the former Czechoslovakia (143). By tracing the links between the sounds of an "unrecognizable language" through the text, we eventually discover Austerlitz's childhood home, and his nanny, Vera, in a townhouse in the Sporkova district of Prague. All this becomes possible through the dovetailing of language and sound in the novel, despite the fact that "the Foreign Office, or the Aid Committee under whose auspices the transports of foreign refugee children had come to England . . . had lost a number of files during their several moves and evacuations, carried out during the bombing of London in very difficult circumstances and almost entirely without trained staff" (143).

No record of Austerlitz exists outside the boundaries of Sebald's novel. Absent Austerlitz, the protagonist cannot dwell anywhere but in a liminal state. Photographs and factssome archival, some created by Sebald himself - place the character always between the boundaries of real/false. Indeed, Austerlitz acknowledges his liminal condition subconsciously throughout the novel as he routinely finds himself dwelling in the "in-between." For example, he frequents train station waiting rooms, caught between coming and going, and compulsively takes photographs of doorways $(143,190-94)$. He confirms to the narrator "the suspicion I had 
always entertained that the border between life and death is less impermeable than we commonly think" (283).

Literary history also serves a key function for us as we excavate a history of violence. Like the protagonist in Balzac's Colonel Chabert, a novella to which Sebald points us throughout the course of the novel, Austerlitz has been buried in a traumatic past. Sebald leaves his reader clues about the French character Chabert, subtly referring to "fifty five volumes of the Comedie humaine" on the shelves of Austerlitz's childhood home in Prague, a trace of what's to come of Austerlitz himself. The volumes, of course, contain Colonel Chabert, but Sebald requires us to locate this information ourselves in order to provide a full account. For indeed, "turning the pages" of Balzac's work is what "tells the story of the great injustice suffered by Colonel Chabert" (181). Sebald challenges us to read closely to piece together Austerlitz. By the end of the novel, the narrator brings us back to Chabert's story, depicting Austerlitz through the nineteenth-century French text: "I began reading the novels of Balzac, hitherto unknown to me, starting with the story of Colonel Chabert, a man whose glorious career in the service of the Emperor ends on the battlefield .... Years later, after long wanderings across Germany, the colonel, risen from the dead, so to speak, returns to Paris to claim his rights" (282).

Almost suggesting that literary history holds a methodology for uncovering human pasts, Sebald omits a key plot element of the Balzac novella: the Colonel had been buried. Assumed dead, the Colonel was thrown into a trench with other bodies from which he had to excavate himself: "I began to work my way through the bodies which separated me from the layer of earth which had no doubt been thrown over us .... I do now know how I succeeded in getting through the pile of flesh which formed a barrier between me and life." "92 Sebald's novel tasks us

\footnotetext{
${ }^{92}$ Honore de Balzac, Colonel Chabert (New York: Quill Pen Classics, 2008), 16.
} 
to uncover the relationship between Austerlitz's story and that of other fictional characters in world literature, but in so doing also displays how forms of recovery lie with the reader.

Through engagement with the novel, we bring Jacques Austerlitz back into being. Such a performance invites the reader to revisit works of imaginative literature in an effort to conceive new terms of restoration. As Walter Benjamin has suggested, a person "who seeks to approach his own buried past must conduct himself like a man digging . . . He must not be afraid to return again and again to the same matter; to scatter it as one scatters earth, to turn it over as one turns over soil." ${ }^{93}$ While the tribunal at Nuremberg excises victim restoration from its model of international criminal justice, the novel might offer a methodology for reclamation. Sebald restages the trial in literary form with an eye toward restorative justice; saliently absent from the novel are references to perpetrators as the reader reclaims Austerlitz's entombed identity. To be sure, recovery does not come through the act of narration itself, but through a dialogic encounter between reader and text. ${ }^{94}$ By the end of the novel Sebald tasks the reader to continue acts of literary exhumation: "And might it not be, continued Austerlitz, that we also have appointments to keep in the past, in what has gone before and is for the most part extinguished, and must go there in search of places and people who have some connection with us on the far side of time, so to speak?" (258).

Austerlitz illustrates a 1945 past of a Holocaust victim who, before the novel, had yet to be recovered. The novel insists that the terms of justice carved out in Nuremberg do not account for victims of mass violence, living and dead. And indeed, the recent cultural impulse toward memorialization and museumfication do little to remedy this omission. In the novel, Austerlitz

\footnotetext{
${ }^{93}$ Walter Benjamin, "A Berlin Chronicle," in Reflections: Essays, Aphorisms, and Autobiographical Writing, ed. Peter Demetz (New York: Schocken Books, 1986), 26.

${ }^{94}$ Simon Gikandi has argued that narrative itself can give "voice" to repressed voices. See Gikandi, "Narration in the Postcolonial Moment: Merle Hodge's 'Crick Crack Monkey,", in ARIEL: A Review of International English Literature, Vol. 20, No. 4 (1989), 15.
} 
describes his own experience traveling to Nuremberg, which reflects upon the victim-centered lacunas at the international criminal trial from which all others have been based. He recalls how he "walked out of Nuremberg station ... into that unknown city" (222).

We can read Sebald's novel as a nodal point in a new conversation about the possibilities for law and literature. As a widely recognized work of global literature, Austerlitz restages an international trial of its own in which the reader must collect and weigh evidence. Yet unlike the procedures at Nuremberg and afterward, the end goal has shifted. Rather than collecting proof of criminality in order to punish perpetrators for human rights violations, we mine the text to reconstruct victim identity. The novel shifts the focus from the criminal(s) to the victim, and it models one literary method through which the reader can help to restore a person in the aftermath of genocide. Given its focus on sites of WWII memorialization, the novel might at first appear to have a carefully circumscribed historical force. Yet in its attempt to portray the limitations of a palimpsestic site of remembrance, it proves that crimes against humanity, regardless of geopolitical positioning, resonate within and through one another. As such, it brings world literature concerning Nuremberg into conversation with texts addressing subsequent moments of violence across the globe, and effectively sets the stage for addressing the diverse regions of Germany, the Soviet Union, the former Yugoslavia, and South Africa in both law and literature.

\section{$* * *$}

Considering the ongoing memorialization of the IMT in Germany and abroad, my first chapter analyzes Arthur Koestler's novel Darkness at Noon (1940) and the significant literary lessons it teaches about Soviet totalitarianism. It examines one of the first omissions at Nuremberg - the absence of Soviet prosecution. The trials in Nuremberg focused on totalitarian 
crimes but without an attempt to discuss Soviet criminality. Bearing in mind the absence of justice with regard to the Soviet Union, Darkness at Noon presents a familiar situation in that region: a victim who once was a perpetrator himself, thus blurring lines of victimhood and setting up the complicated terms of justice. Restoration does not simply stand in stark opposition to retribution, but instead can account for inconsistencies as we think about the nature of justice. Given that the novel centers on a perpetrator-turned-victim as its protagonist, it offers a distinct image of bodily restoration. Initially lauded as a factual account of Stalin's show trials and later propagated as a pedantic tool for Cold War policy, Darkness at Noon became a contentious text in the postwar period. Koestler's body of work stems primarily from the years of World War II, focusing on crimes of both Nazi and Soviet totalitarianism, ethnic violence, and the plight of refugees. While he also wrote a collection of autobiographical texts and a long series of nonfiction essays, Darkness at Noon remains his best-known work. My first aim is to recover the novel from its politically charged past by confronting important distinctions among fact, fiction, and literary significance. Relying on the theoretical work of Hannah Arendt, I challenge political and textual conceptions of human evacuation and recovery after the rupture of World War II. Instead of existing merely as a documentary text that exposes the deprivations of totalitarianism, Koestler's novel presents a portrait of corporeal restoration and the reconstitution of individual self-consciousness as a response to the intimate workings of state terror.

If human recovery requires a remaking of the body and the self, how might contemporary injuries be redressed? This question has specific import for the wounds arising from the former Yugoslavia in the early 1990s. My second chapter interrogates the primary tenets of remedial jurisprudence and their relationship with contemporary conceptions of trauma. Focusing on Aleksandar Hemon's novel, The Question of Bruno (2000), I read it as a 
complex meditation on the limits of national and narrative wholeness. The text evokes

Hemon's own history as a visitor to the U.S. who was unable to return to his home in besieged Sarajevo. The novel depicts the liminal gaps that open up when histories must be narrated from the condition of exile. Hemon defines these "nowhere spaces" as the only locations from which his protagonists can seek out the obliterated "Hemon family archive" lost during the endemic violence in the former Yugoslavia. Indeed, his text reveals the stark limitations of restoration as the law imagines it. Addressing questions of nation, historical recordkeeping, and formal play, the novel draws the reader into a distinctly literary process of repair. This chapter shows how, by collecting and arranging the pieces of emigrant history, the reader becomes a vital tool for healing. Remedy for mass violence, I argue, must be conceived in the same fractured terms that come to define the political refugee.

My third chapter asks what happens when victims are not subject to forced migration, but remain within an injurious geopolitical space. It deals with the work of Nadine Gordimer, a South African novelist and freedom fighter, who won the Nobel Prize in 1991 for her corpus of works addressing racial violence under apartheid, most notably The Conservationist (1974), Burger's Daughter (1979) and July's People (1982). In recent years, her novels have turned to the persistent problems of race and reconciliation in free South Africa. Gordimer once asked a group of novelists, "when, overtly or implicitly, could writers evade politics?" Indeed, during the three years in which Gordimer drafted The House Gun (1998), she relied heavily on South African case law, international jurisprudence, and the discerning editorial eye of Nelson Mandela's lawyer, George Bizos. I argue that The House Gun engages deeply with the reconciliatory efforts of the Commission and the juridical work of the South African Constitutional Court to redefine the terms of reconciliation in the country. Through language in 
a fictional courtroom, her novel turns the process of repair into one that is always immediate and ongoing. It shifts the primarily retributive focus of the law into a reparative and open-ended endeavor. Justice is no longer something that "is done," Gordimer explains. Using The House Gun and post-apartheid jurisprudence as case studies, I show how the novel depicts harm in terms of the interpersonal, spatial, and legal fractures it creates. In this way, it expresses reconciliation in the Commission's language of bridging an injurious past with a present always open to healing. 


\title{
Chapter One:
}

\section{Recovering Arthur Koestler's Darkness at Noon: Literary Fictions, Bodily Restoration, and the Politics of the Totalitarian Novel}

\begin{abstract}
And didn't I myself just say that in the Soviet Union torture was practiced for thirty-four years? And did not already Arthur Koestler ... ? Oh yes, I know, I know. It is impossible to discuss here in detail the political 'Operation Bewilderment' of the postwar period, which defined Communism and National Socialism for us as two not even very different manifestations of one and the same thing. Until it came out of our ears, Hitler and Stalin, Auschwitz, Siberia, the Warsaw Ghetto Wall and the Berlin Ulbricht-Wall were named together, like Goethe and Schiller, Klopstock and Wieland.
\end{abstract}

- Jean Améry

Initially lauded as a factual account of Stalin's show trials and later propagated as a pedantic tool for Cold War ideology, Arthur Koestler's novel Darkness at Noon (1940) has become a contentious text of twentieth-century literature. Its protagonist, N.S. Rubashov, is a former Party official who has been imprisoned in the late 1930s for alleged political crimes against the Stalinist state. Koestler dedicates the book to the actual men who lost their lives in the Moscow Trials, whose experiences informed his creation of the fictional Rubashov. News media surrounding the novel's release emphasized its ability to distill the horrors of the Soviet system and the constant deprivations of the human condition. Much of this journalism accentuates links between Stalinist and Nazi totalitarianism. While historical accounts have both underscored and disputed such associations, ${ }^{95}$ these connections require a radical revision in the way we think about Darkness at Noon and understand the novel's place in the conversation

\footnotetext{
${ }^{95}$ Some historical approaches have described the similarities between Nazi and Soviet totalitarianism, while others have contested such connections, arguing instead that the regimes in Nazi Germany and Stalin's Soviet Union were multifaceted and distinct systems. See, for example, Fitzpatrick.
} 
concerning literature and human rights.

The novel begins with a description of Rubashov's prison entrance. Narrative shifts occur frequently throughout the novel, beginning with a present-tense, third-person narration that depicts Rubashov communicating with a nameless prisoner, No. 402, before moving into various interrogation scenes with two separate guards, Gletkin and Ivanov. These narrations contrast with first-person flashback sequences in which Rubashov recalls moments in his life prior to imprisonment as a Party official, a life history in which he subordinated the human interests of other Party members in order to advance the regime. This shifting narrative standpoint sets up a problem I will expand upon in the chapter. During these moments of flashback, we can see Rubashov's temporal boundaries lengthened. Prior to the flashbacks, he is both physically and mentally stranded in the totalitarian prison. However, his enclosure in the prison cell is lessened through acts of memory and imagination that accompany these narrative flashbacks. As readers, our visual clues into Rubashov's past are limited only to the repeated mention of his pince-nez, through which he regularly was identified in his official capacity. In the prison, Rubashov has retained these glasses, the only physical object remaining of his former identity. The pince-nez is not a mere prop in the novel, but rather becomes a political fetish object through which the boundaries of an internal self-consciousness and the stark totalitarian outer world are played out. Once a device marking the regime's control over Rubashov, the glasses become a tool through which he reacquires sensory perception, self-consciousness, and the foundations of the human condition within the space of his cell.

My reading of Darkness at Noon suggests that Koestler actually is contending with profound complexities surrounding the rise and fall of totalitarianism, and the active role that literature and the imagination play in the restoration of humanity after mass political violence. 
This interpretation works to recapture the novel from its sole political marking as an ideological Cold War text, contending that it is a historically significant portrait of human restoration within the borders of a totalitarian state. In contrast to the reception of Darkness at Noon found in the annals of Cold War conservatism, I trace an alternate history in which the novel functions as a staging ground for both the physical reconstitution of personhood and the metaphysical reformation of individual self-consciousness. How can the novel articulate the complexities of Soviet totalitarianism and the multifaceted nature of human recovery within such a system? Through a contemporary re-reading of Koestler's novel, I seek to recover it from its fraught ideological history and to demonstrate its influence for modern conceptions of restorative justice.

In this chapter, I begin with a historical contextualization of the novel's varied and contentious reception history, moving from its acclaim in the 1940s to its later use as evidence for Cold War policy and action. Next, I seek to challenge the highly politicized history of Darkness at Noon and the ways in which it speaks to the intimate workings of state terror through a reading of the political theory of Hannah Arendt. Here, I acknowledge the significance of Arendt's work but question the limitations of an Arendtian approach. In response to the flattened and narrow account of oppression in her seminal text, The Origins of Totalitarianism, Koestler's novel provides a fuller account of the complicated deprivations and recoveries of humanity that occur in states of tyranny. Arendt's writings provide a basis from which to reconceptualize the human subject within a tyrannical state, while Koestler's work in turn allows us to reimagine Arendt's own thinking, deepening our understanding of the nature of totalitarianism. Accordingly, the next section explores the novel's ability to stage human recovery in its focus on Rubashov's primitive yet salient reacquisition of sensory perception within the totalitarian prison cell. In the fourth section, I consider the efficacy of Koestler's 
novel in speaking to questions of bodily restoration by moving to a reading of the transcripts from the 1938 Moscow Trials, the historical context from which Koestler's novel arose. Here, I will show how these transcripts bear upon questions of representation of juridical bodies, and how methods of literary interpretation can illuminate problems of form, substance, and political power. The final section is rooted in the formal narrative qualities of Darkness at Noon, where I extend my consideration of corporeal restoration by examining the shifts between self/Other, and the manner in which Rubashov redefines the borders of self-consciousness through the power of memory. This chapter ultimately contends that the human deprivations enacted through the language of law and justice might be prominently combatted through the restorative capability of the novel.

\section{Between Truth and Fiction: The Politics of Reception}

Arthur Koestler's Darkness at Noon, published in 1940, was immediately celebrated as an emblematic document of Stalinist totalitarianism. In the years following its initial publication, however, the novel ceased to be a portrait of the human deprivations and recoveries inherent in the Moscow trials. It has since disappeared from traditional academic treatment, while living on as part of the mythology of Cold War communism. Given that Darkness at Noon has been appropriated too quickly as a factual account of Stalinism since its initial publication, it has been taken as a wholly partisan text. Koestler's novel often is paired politically with George Orwell's Nineteen Eighty-Four (1949), as both are studied as near-factual accounts of totalitarian regimes. ${ }^{96}$ Even more than Nineteen Eighty-Four, however, Koestler's text overwhelmingly has

\footnotetext{
${ }^{96}$ Nineteen Eighty-Four might be a direct result of Orwell's interest in fiction and politics. In his 1946 essay, "Why I Write," Orwell expounded, "[e]very line of serious work that I have written since 1936 has been written, directly or indirectly, against totalitarianism and for democratic socialism, as I understand it. It seems to me nonsense, in a period like our own, to think that one can avoid writing of such subjects" (314).
} 
been displaced from a position in literary scholarship and treated instead as a politicized

historical document. Darkness at Noon is perhaps the most forgotten of all remembered novels. We think we remember its plot and its historical significance, yet in a moment more than seven decades after its first publication, its overlooked literary complexity prevails over its presumed political weight and presents an opportune moment for re-reading and recovering this text from its stagnant place in Cold War history. ${ }^{97}$ Tracing the novel's historical treatment provides us with specific knowledge of the socio-political context(s) in which it originally was written and read. A closer contemporary reading of the text, however, lays bare the much deeper and multifaceted work in which Koestler was engaged.

Koestler wrote Darkness at Noon while seeking political refuge in Paris between 19361939. ${ }^{98}$ Although written in German, the novel's first publication occurred in English translation in London in late 1940, several months into the Blitz. ${ }^{99}$ Since it was released during wartime in England, neither The Times nor The Guardian published a review, and the novel sold only a small number of copies in the United Kingdom that year. However, Darkness at Noon garnered

\footnotetext{
${ }^{97}$ Darkness at Noon is perhaps the quintessential text for a "novel recovery," due to its relegation to political and cultural histories. See Bloom for a discussion of the limited literary value of a "historical novel"; for a more ameliorative view of Koestler's work, see Berkowitz, who writes: "Darkness at Noon is acclaimed as one of the most important books of the twentieth century-it is number eight on the Modern Library's list of the Hundred Best Novels of the twentieth century. Yet, given its enormous impact, its philosophical ruminations, and its political theme, the novel has garnered surprisingly little academic consideration. It is worth asking, therefore, why Darkness at Noon has not been taken seriously by the academic community. One answer is that Koestler's later work-his curmudgeonly conservatism, apparent misogyny, and forays into pharmaceutical-based utopias - discredited him as a serious intellectual. Koestler's novel, it seems, suffers for the perceived exoticism of his later work, much of which developed and reaffirmed the importance of the paranormal in politics. Another answer is that the novel suffered from its own success. So much public attention focused on the question of whether Bukharin or Trotsky was the model for Rubashov, and whether Darkness at Noon was an accurate reflection of the Soviet show trials, that the more ambitious and theoretical questions Koestler raises were overlooked or assumed to be of secondary importance" (Berkowitz 297-98).

${ }^{98}$ Koestler was born in Budapest in 1905, joined the Communist Party in 1931, and traveled throughout Central and Eastern Europe. With news of Stalin's purges and the rise of the Nazi regime, Koestler moved westward to Paris, and later to London. See Koestler, Scum of the Earth (1941) and Arrow in the Blue (1952).

${ }^{99}$ This novel has only been read in translation. Koestler wrote it in German while living in France with Daphne Hardy, who translated the text into English and brought it to London in 1940. Koestler's original German-language version was lost in the pre-war years, and the only German-language copies ever published were translations from Hardy's English translation. As such, the novel is an original "English-language text" in many ways, but also is an example of a global novel that is "always already" in translation.
} 
critical attention and commercial success upon its U.S. publication in May of 1941. Popular reception varied, however, based on the perceived function and utility of the novel. Some reviewers took a backward-looking approach, assuming that Koestler merely had transcribed historical events into fictive form - the novel was more a historical document than a literary work. ${ }^{100}$ This praise was rooted in a focus on its documentary quality without attention to questions of literary language and narrative form. A similar documentary impulse also stressed that literature born of 1930s politics simply reflected those politics realities without attending to the complex interplay between fiction and politics. ${ }^{101}$

In addition, Darkness at Noon also became a cultural trope and metonym in the vast postwar years, taking on content unrelated to the substance of the novel itself while continuing to fuel anti-Communist conservatism. ${ }^{102}$ Rumors circulated concerning the identity of the "Real Rubashov"-Trotsky? Bukharin? — while other news reports discussed "factual echo[s]" of "Koestler's fictional classic," referring to both Laszlo Rajk, "the dead, if rehabilitated, Hungarian 'Rubashov,” and Arthur London, a "true-life Czechoslovak ‘Rubashov"” (Sulzberger 28). ${ }^{103}$ In fact, the 1960s Powers Trial ${ }^{104}$ centrally reinvigorated documentary use of Darkness at Noon. Questions arose concerning "whether the [Soviet] system's judicial philosophy ha[d] fundamentally altered" since the show trials of the 1930s, and journalists referred to the "artificial confessions . . . best described by Arthur Koestler in 'Darkness at Noon"” (22). In fact, when the 1973-1978 confessions of so-called Soviet dissents Pyotr I. Yakir, Viktor A.

\footnotetext{
${ }^{100}$ For additional examples of this phenomena, see Strauss 6; Barish C6.

${ }^{101}$ A New Republic essay described the 1930s as a "period when literary events followed so closely on the flying coattails of social events .... [T] he time between event and expression was so short that no one could miss their connection - and least of all the author himself" (Cowley 347-48).

${ }^{102}$ See Baldwin for a discussion of the novel's perceived anti-Communist threads during the mid-1950s.

${ }^{103}$ See, for example, Stockdale's 1982 op-ed citing the novel as evidence for anti-communist force in Vietnam

${ }^{104}$ Francis Gary Powers was an American Air Force pilot who, after an honorable discharge, became a U-2 pilot for the Central Intelligence Agency. In 1960, Powers' U-2 was shot down over south-central Russia, and he was tried and imprisoned for espionage against the Soviet Union. After serving two years of a ten-year sentence, he was exchanged in a prisoner swap and returned to the United States.
} 
Krasin, and Yori Orlov became newsworthy in America, reports described these incidents as

"Darkness at Noon trials" (Shabad 4).

As Western fears grew surrounding the spread of Communism in the 1950s and 1960s, Darkness at Noon remained a prominent evidentiary text. In 1967, William F. Buckley, Jr. praised Koestler as an artist who had provided witness to the "rather unpleasant sight" of the Soviet Union, thus driving and enlivening anti-Communist conservatism. "Such words" as Koestler's, wrote Buckley, “imperishable, unforgettable, have been written by the master witnesses of the past 50 years" (Buckley 4). By 1969, British author John Braine cited Koestler's novel as a central factor in why he "turned conservative" (Braine SM24). Even into the 1970s and 1980s, Koestler's novel remained an instrument for neo-conservatism while moving farther from a marked position in literary scholarship.

This reception history raises three questions that become central to a 21 st-century recovery of Darkness at Noon. First, journalistic accounts of the novel present the literary question of a political versus a more subtle reading of a complex text. Next, its vast and varied reception poses the problem of a documentary rather than a fictional association with a very prominent twentieth-century novel. And finally, the book's history implies that the text solely is a critique of totalitarianism and a portrait in human deprivation. Yet through a more nuanced reading that challenges Arendt's conception of totalitarianism, I contend that it is also an affirmation, providing insight into the distinct modes of restoration that develop within such a regime.

\section{The Metaphysical Origins of Totalitarianism}

While journalists and politicians sought to extract documentary explanations for and 
evidence of totalitarianism from literature, Arendt began a work of political philosophy on the very subject in the immediate postwar years. In 1951, she published The Origins of Totalitarianism, a leading interpretation of the historical causes and political realities of Nazism and Stalinism. Her work focuses on the human deprivations enacted by these regimes in the middle of the twentieth century. While certain of Arendt's ideas help to provide a framework in which to conceive of the deprivations of totalitarianism, I will show the limitations of her approach in considering the restorative capacity of the global novel.

In Arendt's work, a key tenet of totalitarian criminality is the dedication to a form of thought and action, regardless of its content. ${ }^{105}$ She suggests that the substance behind a regime's methods and objectives is subordinate to the shape that regime takes; as long as a totalitarian form is intact, the regime can contain any and all "ideas," which can change at whim and without consequence. As such, a totalitarian state need only convince its followers to dedicate themselves to the idea of an idea, a less lofty endeavor than converting a nation into a mass of "true believers" (Arendt, Origins 307).

In Arendt's writings on form and content distinctions, the terms themselves often become evacuated abstractions difficult to ground in experiential practice. But her texts elucidate two strands of this feature. The first is a metaphysical one: a mode of governance that constantly can change the substance of its rule while guaranteeing that its followers will adhere to its form. Only the shape of the government matters; the substance inside or propelling the regime is irrelevant. This might best be explained by the form of Stalinist revolution. Its members adhered to the shared goal of revolution in the abstract, regardless of the violative ways in which it was carried out. Ends are pursued regardless of means, and means can change willy-nilly.

\footnotetext{
${ }^{105}$ Some critics of Arendt's seminal text contend that she pejoratively conflated Nazism and Stalinism, despite Arendt's attestations to the contrary. See, for example, Parekh.
} 
This destruction ultimately shows itself when, "to the wonder of the civilized world, [the totalitarian party member] may even be willing to help in his own prosecution and frame his own death sentence if only his status as a member of the movement is not touched" (307). ${ }^{106}$ Arendt suggests that the inevitable outcome of a regime such as this is a governing practice in which the content is not only subordinate to the regime's form, but itself becomes only terror.

Separate from this strand, Arendt also alludes to a more physical differentiation between form and content. Since the appearance of a human body necessarily implies human substance within (i.e., its physical presence suggests that that body is made up of a thinking, self-conscious individual), totalitarian regimes turn a visual human signifier into a false one; the human form ultimately is voided of its assumed human interior. Accordingly, totalitarianism threatens all bases of knowledge and meaning, for if the form of a human does not signify a human within, knowledge of our very essence is imperiled.

In Koestler's work, we see this embodied in a very basic level of the juridical person. The "law" is introduced in a seemingly legitimate form with Rubashov's purportedly lawful arrest. As Rubashov's home is raided by Stalin's secret police, one of the young officers informs him: "Citizen Rubashov, Nicholas Salmanovitch, we arrest you in the name of the law" (Koestler 7). When Rubashov doesn't move from his bed, the young officer and Rubashov argue: “'You hear you are arrested .... Put on your clothes and don't make a fuss.' 'Have you got a warrant?' asked Rubashov. The elder official pulled a paper out of his pocket, passed it to Rubashov and stood again at attention. Rubashov read it attentively. 'Well, good,' he said.

\footnotetext{
${ }^{106}$ The idea of "building blocks for a human form without human content" is perhaps best exemplified through what Koestler refers to as the "so-called Moscow Trials," a series of show trials designed to "liquidate" high-ranking members of the Soviet bureaucracy. Arendt explains how a totalitarian desire for consistency of form, resulting in a complete void of content, eventually leads to the complete breakdown of human individuality and spontaneity. This destruction ultimately shows itself when, "to the wonder of the civilized world, [the totalitarian party member] may even be willing to help in his own prosecution and frame his own death sentence if only his status as a member of the movement is not touched" (Arendt, Origins 307).
} 
'One is never any the wiser from those things"' (7). Rubashov looks only for a paper taking the form of a warrant - a document presented by law enforcement with an explanation of reasonable cause for home entry and arrest—rather than a document with actual legal substance to guarantee his individual rights.

This feature also plays out in Darkness at Noon in the form of the "grammatical fiction"- the physical appearance of an "I" or an individual, but one who has been stripped of the qualities that make up the very substance of a person. The "grammatical fiction" is a phrase invented in this novel, as Rubashov struggles to find language to explain the regime's denial of individuality while insisting upon each Party member's singular and unquestioned commitment to the system. In Origins, the grammatical first person is turned into a mere fiction-only the shell of an "I"- through totalitarianism. Another way of understanding the "grammatical fiction" is by examining Arendt's observations of the ideal totalitarian party member, embodied for her through Adolf Eichmann. The key qualities of such a man are the opposite of those belonging to a "true believer." A Party member like Eichmann has the markers of a "normal" person but lacks any of the "normal" components of humanity. ${ }^{107}$ On the outside, Eichmann looks like an "I," or a physically individuated human being, yet he is devoid of the capacity for thought, morality, and conscience. In questioning the totalitarian methodology that has created a figure like Eichmann, Arendt explains how a seemingly conscionable person can lose certain abilities when forced to function under totalitarian rule:

And just as the law in civilized countries assumes that the voice of conscience tells everybody "Thou shalt not kill," even though man's natural desires and inclinations may at times be murderous, so the laws of Hitler's land demanded that the voice of conscience tell everybody, "Thou shalt kill," although the organizers of the massacres knew full well that murder is against the normal desires and inclinations of most people .... Many Germans and many Nazis, probably an overwhelming majority of them, must have been tempted not to murder, not to let their neighbors go off to their doom, and not to become

\footnotetext{
${ }^{107}$ For a discussion of such 'normalcy,' see Eichmann 26-27.
} 
accomplices in all these crimes by benefitting from them (Arendt, Eichmann 150).

Koestler recognizes many of these characteristics in Darkness at Noon, yet his novel exists in complicated relation to Arendt's writings. While The Origins of Totalitarianism has become a key text for interpreting the deprivations resulting from modern mass violence, Koestler's novel stages more than the mere evacuation of the human condition. Arendt seeks to explain totalitarianism's form, its intended results, and the danger it poses to human existence. Koestler's novel traces the ways in which humanity is both subject to extreme deprivation yet still (inexplicably) capable of reconstitution, both bodily and metaphysically, in the face of tyranny.

A deeper analysis of Arendt's work on the variances between form and content can elucidate the complex relationship between Darkness at Noon and her own political philosophy. The relationship begins with the premise that everyday life in the Stalin years was defined by a strict attention to the form of human existence without the substance of humanity, both in the sense of Koestler's "grammatical fiction" and in Arendt's characterization of Eichmann. With regard to the metaphysical feature, she describes one of the key features of totalitarian movements as the "emptying" of socialism and racism "of their utilitarian content," such that "the form ... become[s] more important than [the] content" (Arendt, Origins 348). Here, a totalitarian regime's use of the "ideas" of socialism or racism to further megalomania actually establishes the shape of the movement. Once this is done, the regime can change its substance easily and without dissent. In other words, socialism itself ceased being essential to Stalin's regime; such a movement can employ any substantive qualities, socialism or otherwise, to achieve "revolution." This metaphysical movement between form and content is a precursor for the related physical characteristic. For Arendt, the strands together create a symbiotic 
relationship.

The physical strand begins with a series of steps intended to radically separate individuals from one another, which begins with an individual's isolation from family and community, is followed by his bonding with the regime alone, and eventually leads to the impossibility for human dialogue and a resulting loss of humanity. In thwarting dialogism, this radical isolation ultimately forestalls all human spontaneity and the ability to think outside the confines mandated by the regime. Such human isolation is central to totalitarian movements that, at their core, "are mass organizations of atomized, isolated individuals" (323). It is this quality that ultimately enables the "grammatical fiction" at stake in Koestler's novel— the physical appearance of a human without human substance.

Arendt conceives of "mass atomization" as a process by which a totalitarian regime establishes a hyper-individuality whereby both physical and mental space is forced between and around everyone, which is tied inextricably to an individual's removal from his community and the knowledge of belonging within it. It begins with the "destruction of all social and family ties ... in such a way as to threaten with the same fate the defendant and all his ordinary relations, from mere acquaintances up to his closest friends and relatives" (323). Individuals in constant fear for their own safety remove themselves from familial and social circles to avoid any presumed connection with others - friends and family — who may be targeted as enemies of the regime. The individual learns to consider himself before and above all others. Arendt explains this as:

The consequence of the simple and ingenious device of 'guilt by association' .... [A]s soon as a man is accused, his former friends are transformed immediately into his bitterest enemies; in order to save their own skins, they volunteer information and rush in with denunciations to corroborate the nonexistent evidence against him ... . [T] he most elementary caution demands that one avoid all intimate contacts, if possible - not in order to prevent discovery of one's secret thoughts, but rather to eliminate, in the almost certain 
case of future trouble, all persons who might have not only an ordinary cheap interest in your denunciation but an irresistible need to bring about your ruin simply because they are in danger of their own lives (323).

In the absence of "any other social ties to family, friends, comrade, or even mere acquaintances," this human being "derives his sense of having a place in the world only from his belonging in a movement, his membership in the party" (323-24). To summarize, through radical isolation, he loses the dialogism inherent in community membership. That loss is replaced only with knowledge of loyalty to the regime association, which becomes possible "only when fidelity is emptied of all concrete content, from which changes of mind might naturally arise" (324). At such a stage, fidelity and loyalty are terms that, like "human," have been stripped of all substance except in relation to the regime. Their proximity to totalitarianism has altered their presumed cultural and linguistic signifiers and has replaced them with tyrannical ones. This stage requires that the form of the regime already has been established, and then through mass atomizationthe beginning stages of the stripping of human substance - the metaphysical form of the regime grows in importance as its content wanes.

Without the faculty for dialogic encounter, Arendt suggests, the human being loses his ability to think. Isolation from a dialogic public realm then precludes the possibility for meaningful thought or action against the regime, as human encounter both fosters and develops the action that stems from thinking. Arendt defines this stage of utter isolation as loneliness. "What makes [it] so unbearable," she explains, "is the loss of one's own self which can be realized in solitude, but confirmed in its identity only by ... company of equals" (477). Significantly, a partnership with oneself is the last to go; one abandons self-interest in such a way that collapses any remnants of individual thought. It "forces man to lose all trust in himself as the partner of his thoughts and that elementary confidence in the world which is necessary to 
make experiences at all" (477). Arendt characterizes dialogism as an inherent part of the human condition. Without dialogism, the human condition is at stake. For with the loss of a capacity for thought, one also eludes the related human potential for spontaneity and morality, the very traits that define individuality and human inimitability. Accordingly, entrapment within the enclosed space of a totalitarian state thus threatens its permanence, as it is the spark of spontaneity that may be the only element capable of breaking the "insane logic" and consistency of totalitarianism, and of carving out a new space in which humanity can operate outside the regime's totalizing space. This destruction of the "uniqueness of the human person" in turn signifies the destruction of the "moral person," as the foreclosure of spontaneity and morality are closely intertwined; with the impossibility for thought, questions of conscience become "absolutely questionable and equivocal" (452). Arendt explains that "[w]hen a man is faced with the alternative of betraying and thus murdering his friends or of sending his wife and children, for whom he is in every sense responsible, to their death; when even suicide would mean the immediate murder of his own family — how is he to decide? The alternative is no longer between good and evil, but between murder and murder" (452). The once-ethical person, whose conscience no longer can guide him between wrong and right, is stripped of moral content"living corpses," Arendt writes (451).

These Arendtian terms paint a seemingly oxymoronic image of a totalitarian state defined by impenetrable borders that serve to enclose and suffocate all within them, while simultaneously isolating each individual from one another. Yet this ostensible disparity marks the particularity of a totalitarian state in which all knowledge arises and is circulated from within, ${ }^{108}$ yet no information is shared through dialogic interaction. It becomes impossible to

\footnotetext{
${ }^{108}$ Such an idea conjures a perversion of Foucault's conception of the circulation of power. See Foucault 37-54.
} 
think outside, and even physically to be outside the regime. ${ }^{109}$ Once enclosed inside its boundaries, the inability even to move is called into question; with the eradication of a space for thinking, even physical movement becomes controlled. Arendt suggests that "when operating at its most successful level, totalitarianism achieves a form of totality that forecloses the possibility of an 'outside"" (325). It is perhaps the seeming contradictions and impossibility of such a space that permits it to continue without interruption. And this type of simultaneous suffocation and isolation relies on the success of both strands of the form-and-content differences that Arendt elucidates.

This destruction of the human condition must also coincide with a continuous threat to human recovery. In its critique of totalitarianism, Darkness at Noon exemplifies the ways in which such a regime threatens this restoration; the persistence of "physical liquidations" and mentally torturous interrogations consistently endanger Rubashov's sensory reclamation. While Darkness at Noon ultimately can be read as a portrait in human recovery, it also exposes the persistent deprivations inherent in totalitarianism. Koestler creates a portrait of human evacuation that speaks to Arendt's work in political philosophy, only later to complicate her focus on human frailty by depicting the possibilities for human reconstitution from within a system founded upon tyranny and megalomania.

Following a passage of dialogue between Rubashov and No. 402, the prisoners realize that No. 380, a former sailor on the famed Battleship Potemkin, is being prepared for execution. This awareness creates a pervasive sense of terror that begins to thwart human recovery as Rubashov and the other prisoners are transformed into mere numbers set for arbitrary liquidation.

\footnotetext{
${ }^{109}$ In Darkness at Noon, an extract from Rubashov's diary betrays his acknowledgement of the totalizing "insideness" of Stalinism while reflecting on his actions as a Party official: "We resembled the great Inquisitors in that we persecuted the seeds of evil not only in men's deeds, but in their thoughts. We admitted no private sphere, not even inside a man's skull" (Koestler 100).
} 
On the most primitive level, the prisoners' ability to hear becomes wholly suppressed:

"Rubashov listened .... The silence thickened. He took off his pince-nez and tapped to No. 402 in the adjoining cell: I HEAR NOTHING .... For a while No. 402 did not answer" (140). When No. 402 finally responds to Rubashov, he only taps "loudly and sharply: NO. 380. PASS IT ON" (140). The potential for dialogue devolves into confirmation of the regime's power to destroy individual identity as the prisoners themselves limit contact to rote reiterations of the numbers assigned by the regime as identity markers. This moment predates the Arendtian caution against Nazi totalitarianism, which "discovered a means of dominating and terrorizing human beings from within" (325). The prisoners are made fully aware of the arbitrariness of life and death, consistent only in their invariable content of terror. Such a realization leads their tapping to grow to a "low, hollow sound of subdued drumming" that is neither "tapping nor hammering: the men in cells 380 to 402 , who formed the acoustic chain and stood behind their doors ... brought out with deceptive resemblance the muffled, solemn sound of a roll of drums" (143). Both hearing and speaking have been made impossible as the regime arbitrarily institutes the execution.

At this point, Rubashov's pince-nez, used at earlier moments for a restorative dialogue with No. 402 , is rendered impotent, and even certain olfactory memories are overwhelmed by the space of the prison. Prior to the news of the execution, Rubashov sifted through memories of Arlova, his former secretary and lover: "He sniffed and noticed that for some time already he had the scent of Arlova in his nostrils. Even the cigarettes smelled of her; she had carried a leather case in her bag and every cigarette out of it had smelled of her powder" (140). However, with the cessation of tapping-based dialogue and the confirmation of the arbitrary power held by the regime, Rubashov's tapping contains only the proscribed content of physical liquidation: “[He] 
tapped to No. 406: ATTENTION. No. 380 IS TO BE SHOT NOW. PASS IT ON. He listened. The bucket stank; its vapours had replaced the scent of Arlova. There was no answer. Rubashov pattered hastily back to the bunk. This time he tapped not with the pince-nez, but with his knuckles: WHO IS NO. 380? There was again no answer" (140-41).

The more significant threat to human reclamation occurs in connection to Rubashov's interrogations and the obstruction of memory and imagination. In moments leading up to a socalled 'hearing' with the guard Gletkin, Rubashov's capacity for creativity erodes. Anticipation of "confessing" to crimes that he did not commit at first has no bearing on Rubashov's desire for dialogue with No. 402. Yet as he taps against the wall it "remain[s] silent" (184). The aurality hindered here mirrors that of the execution; despite a desire to hear, the regime's prison denies it. Rubashov's aural senses become evacuated of content when meaningful dialogue ceases. This moment operates as a harbinger, as uniformed officials arrive to escort Rubashov to his interrogation (185). Here, Rubashov regresses to a form proscribed by the regime. Recalling his former role as a Party official identified by his pince-nez, Rubashov "felt for his pince-nez under the blanket, put them on, and got up from the bunk" (185). He then reverts to mannerisms previously proscribed by his Party position as he finds himself "mechanically rubbing his spectacles on his sleeve" (186).

Both image and action become void of meaning as Rubashov regresses toward the shell of a human being, defined only in his relationship to the Party. Within the Stalinist state, Rubashov's pince-nez is a visual marker of the Party's power to anyone who sees Rubashov, while it is also an item emblematic of Rubashov's sight as proscribed by the regime. Even in the interrogation room when faced with a blinding "sharp white light which streamed from the exceptionally strong bulb," Rubashov still attempts to use his pince-nez for sight (187). 
Although "the light hindered him," Rubashov "knew that without glasses he looked naked and helpless," so he "put his pince-nez on and tried to meet Gletkin's gaze" (188). Throughout this moment, the blinding light forces Rubashov to weep, yet he insists on keeping his eyes open. As a result, Gletkin succeeds in thwarting Rubashov's ability to employ even the most primitive sensory perceptions.

Yet the "accursed inner voice" of conscience returns to Rubashov in the final moments of his interrogation, setting up the novel's unique restorative power (156). As such, Koestler's novel stands in complex relation to Arendtian logic and the power of humanity to operate from within a totalitarian system. While Arendt seeks to explain the ways in which totalitarian regimes create "living corpses" evacuated of the capacity for thought, spontaneity, and conscience, Koestler acknowledges these human deprivations, but then imagines their reconstitution despite persistent dangers. By the end of Rubashov's interrogation, he brings meaning to sight and aural perception, as well as to the legal terminology that has been turned to malapropism by the regime. He "trie[s] to look into [Gletkin's] face" but realizes that he cannot and makes the decision simply to "shut his eyes" (193). Accordingly, he recovers his hearing through a final bodily act outside the regime's control and reinscribes meaning to the notion of legal "confession." Following his eye closure, Rubashov takes a moment to think—an act that Arendt argues is impossible within the confines of totalitarianism — and he extracts a mode of oppositional affirmation:

He had had a biting answer on his tongue; instead he said, so quietly that the thin secretary had to stretch out her head to hear: 'I plead guilty to not having understood the fatal compulsion behind the policy of the Government, and to have therefore held oppositional views. I plead guilty to having followed sentimental impulses, and in so doing to have been led into contradiction with historical necessity. I have lent my ear to the laments of the sacrificed, and thus became deaf to the arguments which proved the necessity to sacrifice them. I plead guilty to having rated the question of guilty and innocence higher than that of utility and harmfulness. Finally, I plead guilty to having 
place the idea of man above the idea of mankind ... .' (194).

He turns the interrogation-confession from a one-way encounter into a dialogic one in which he is able to ruminate on his role in the Party and the power of human thought. ${ }^{110}$ In so doing, he solidifies aurality as a sense deeply rooted in humanity: hearing becomes an amenity for victims and oppositional voices while it is denied to the regime that seeks to strip it of human content. Accordingly, Rubashov's final moments become filled with thought and imagination, with "memories pass[ing] through him, like streaks of mist over the water" (271). Through Rubashov, Koestler ultimately reveals the permeable line between fact and fiction, and the interplay between legal history and literature.

Although he ultimately signs a content-less confession, Rubashov's submission to the regime is marked not by the act of succumbing but by the manner in which he does so. Gletkin insists that the purpose of signing a false confession is "to avoid awakening sympathy and pity" because any appeal to humanity is "a danger to the country" (243). However, Rubashov's true confession is exactly that; the final confession is that which we bore witness to above. As a result, Rubashov's final moments of life, a chapter heading entitled "the Grammatical Fiction," suggest that the so-called fiction of individuality in communism (or the "I") is not at stake, but rather the grammatical fiction of the "confession" read aloud prior to Rubashov's execution.

Rubashov's final moments are marked by a capacity for individual thought and imagination. Importantly, he acknowledges that his execution is not a valid tool to further the regime: “[W]hen he asked himself, For what actually are you dying? he found no answer" (265). He exposes the faulty basis upon which the regime has been constructed: one of radical logic that extracts its human components to a point at which all actions merely aid the form the regime has

\footnotetext{
${ }^{110}$ For a discussion of the distinctions among the cultural, social, and legal modes of confession, and the inability for legal interrogation to yield 'true' confessions, see Brooks' Troubling Confessions 113-25.
} 
taken, or through "reason alone." Rubashov thinks of "the weird and ghostly game of the public trial" borne out of the "running-amuck of pure reason" (263). After elucidating the regime's flawed form, Rubashov lays bare its fictional content. He refers to the "Fatherland of the Revolution, the Bastion of Freedom!" and explains that "Gletkin justified everything that happened with the principle that the bastion must be preserved" (264). "But," Rubashov questions, "what did it look like inside? No, one cannot build Paradise with concrete. The bastion would be preserved, but it no longer had a message .... There was an error somewhere in the equation—no, in the whole mathematical system of thought" (264). His final moments become filled with thought and imagination, with "memories pass[ing] through him, like streaks of mist over the water" (271). Through Rubashov, Koestler ultimately reveals the permeable line between fact and fiction, and the interplay between legal history and literature. Such connections are further illuminated, as I will show, in literary scenes of Rubashov's recovery of bodily control, memory, and imagination.

\section{Sight and Sound: The Physical Reconstitution of Personhood}

As the scenes of Rubashov's interrogations suggest, totalitarianism does threaten a deprivation of the human condition. Yet Darkness at Noon significantly reveals the ways in which humanity can persist despite, and within, such a system. Through Rubashov's recovery of sensory perception notwithstanding the proscriptions of the prison system, the novel stages a

bodily reconstitution of personhood. Koestler's grappling with this recovery begins at the outset of his text through the language of his chapter titles, which immediately illuminate a struggle with the distinctions between form and content that pervade the novel. The very first section of the novel, "The Hearing," is not marked by a courtroom examination in which the accused is 
permitted to "be heard" by a judge and jury before sentence is pronounced upon him. Instead, the novel's section titles — all numerically ordered "Hearings"-illuminate the fictive quality of totalitarian "justice."

The novel's restorative capacity does not lie in its ability to reinstate original meanings to the legal language misappropriated by the regime. Instead, its staging of human recovery relies upon the very bodily reconstitution that often is the last to go. Thus rather than reinscribe content to legal terminology—Rubashov is never "heard" by practitioners of justice—-the novel goes outside these denotative constraints and uncovers a more primal meaning for the term "hearing." The "First Hearing" is not a judicial one, but a sensory one in which the reader is implicated. The first line of the novel we read is also one we hear: "The cell door slammed behind Rubashov" (1). ${ }^{111}$ A physical description of the prison structure follows, based in aurality. The narrator explains that "[t]he walls on both sides were of solid brick, which would stifle the sound of tapping, but where the heating and drain pipe penetrated it, it had been plastered and resounded quite well; besides, the heating pipe itself seemed to be noiseconducting" (1). A "hearing" need not refer only to one in a court of law; a "hearing" can be given meaning, even within this totalitarian prison system, through sensory perception. This seemingly simplistic opening to his novel provides a base upon which Koestler builds a complex and nuanced recovery of the elements of the human condition.

The reconstitution of aurality begins to take on a multi-faceted meaning. The structure of the prison is intended to control bodily movement and human knowledge, ${ }^{112}$ yet the aural sense

\footnotetext{
${ }^{111}$ Orwell links the notion of "hearing" to "reading," specifically the power of book-related hearing and the ability to combat falsities and injustices: "When I sit down to write a book ... . I write it because there is some lie that I want to expose, some fact to which I want to draw attention, and my initial concern is to get a hearing" (315).

${ }^{112}$ In both Jeremy Bentham's panopticon and the Soviet prison in which Rubashov is held, the prison takes power over the physical bodies of its prisoners. This compares draws out the differing natures of biopower in distinct prison systems; unlike Foucault's reading of the panopticon, structured so that one guard constantly can see all
} 
can transverse this. As intended by the regime, the prison cells are ones in which sight lines are strictly proscribed. Frequently, the "judases" in the cell doors are used only for guards to look in on prisoners; one rarely sees out. Upon Rubashov's arrival at the prison, just "a few minutes later the warder turned the light off from outside, and looked through the spy-hole into his cell, Rubashov, ex-Commissar of the people" (2). Even in moments when prisoners use the spyholes, sight is strictly controlled. Rubashov's first vision through the judas supplies an image of orderlies bringing bread to cell number 407. But as we learn that "No. 407 was just being given bread," we simultaneously learn that "Rubashov could not see him," as his "range of sight held [only] four of the cells opposite" (17-18). As such, the act of "seeing" is pejoratively redefined. It no longer signifies a range of images processed through Rubashov's eyes and lines of sight, but rather the very limited knowledge demarcated by the regime. In this way, the Party uses the prison structure and the prisoner's own sensory perceptions against him. "Seeing" is stripped of its traditional content, as the only vision that Rubashov and the other prisoners maintain is that which the system controls.

The novel initially suggests that the totalitarian system has envisaged a way in which to control the senses, both sight and sound. Through torture, it has deprived Rubashov of his physical ability to hear. The novel details the "first smashing blow over the ear with the butt of the pistol ... from which [Rubashov's] deafness dated" (4). Further, like its control over sight, the space of the prison itself exacerbates the denial of sound. Through the "honeycomb in concrete" construction of the prison isolation cells, "one heard nothing-except from time to time retreating footsteps in the corridor" (12). And since "Rubashov knew that he was in an isolation cell and that he was to stay there until he was shot," the novel implies that he hears prisoner without being seen. For further explanation, see Foucault, Discipline and Punish. 
nothing from within the cell- his hearing is controlled completely (12).

Similar to that obtained through the prisoners' sight lines, the knowledge gleaned through aurality becomes controlled entirely by the regime. When Rubashov hears the sounds of marching, he knows that torture will begin: "His first thought was: now the beating-up will start" (16). The physical act of walking is also combined here with sensory perception to strip meaning from any "hearings." The prison structure is designed so that nothing but these footsteps are heard, and as a result, that which prisoners hear only amplifies the regime's biopower and its institution of terror. The regime has altered the signifier of heard footsteps and its signified. Instead of indicating simply "someone is coming," the footsteps now signify "someone is being tortured." All sounds heard by the prisoners, through their own bodily capacities, serve only to intensify the terror that the regime can perpetrate from within; the prisoners enact a fundamental terror of becoming physically responsible for their own horror. The knowledge and meaning produced from certain sounds, or obtained through hearing, has been stripped of substance and replaced with a specific kind of totalitarian "knowledge." The totalitarian replacement of true knowledge and understanding with inviolable consistency allows Rubashov to "know" precisely what will follow the corridor footsteps. After hearing the corridor marching, "Rubashov stood stiffly between the bed and the bucket, held his breath, and waited for the first scream [because] he remembered that first scream, in which terror still predominated over physical pain, which was usually the worst; what followed was already more bearable, one got used to it" (16). ${ }^{113}$

Yet this terror cannot thwart the human capacity to reconstitute itself. The deprivations of hearing, however, soon are combatted with the possibility for redefining sensory perception

\footnotetext{
${ }^{113}$ There is an implication here that physical pain — another return to the body—can break the prison-structure control of hearing; the very physicality that the regime threatens at once also breaks the regime's control. See, for example, Scarry.
} 
and meaning outside the confines of the regime at a moment in which Rubashov "ha[s] a sudden wild craving for a newspaper" (14). Instead of yearning for the words and images associated with a newspaper, Rubashov instead thinks of its smells and sounds: "[The craving] was so strong that he could smell the printer's ink and hear the crackling and rustling of the pages" (14). Rubashov extracts both an aural and an olfactory distinctiveness that turns the object into something new. An entity bearing only knowledge produced by the regime — a Soviet newspaper - is repurposed through Rubashov's memory into an object capable of penetrating the totalizing nature of sensory knowledge produced by the regime.

The newspaper marks the beginning of Rubashov's aural recovery through a repurposing of objects previously associated with the regime's power alone. This process strengthens as Rubashov repurposes his pince-nez, an instrument that once identified him as a high-ranking Party member. At its most basic, a pince-nez is worn in order to see, a capacity that has been limited and controlled by the regime. But for Rubashov, the action of seeing always was defined in relation to his Party position: "Rubashov felt for his glasses under the pillow and propped himself up a bit ... Now that he had his glasses on, his eyes had the expression which Vassilij [his neighbor] and the elder official knew from old photographs and colour-prints" (7). The image of Rubashov wearing the pince-nez is solidified as one synonymous with his role as party member in the first hours of his imprisonment. Before placing the appliance over his eyes, Rubashov "rub[s] his pince-nez on his sleeve with the gesture familiar to all his followers" (12). However, while trying to see through these glasses while a prisoner, Rubashov slowly begins to think outside the system that he has helped to create. As he puts on his pince-nez, he "wonder[s] whether he really should scrub the tiles," as the guards have ordered him (22). Such “outside thoughts" soon begin to permeate Rubashov's imagination, specifically with regard to 
the merits of Stalinism. In so doing, he begins to carve out a distinctive "I" in relation to the oppressive collectivism of the regime; with the reestablishment of a meaningful sense of sound, Rubashov also begins to recover an identity for himself in which thought, memory, and imagination become central to his very being. He first refers to Party members as separate from himself: "They will shoot me, thought Rubashov. My motives will be of no interest to them" (23 emphasis added). Rubashov then muses: "The old disease ... . Revolutionaries should not think through other people's minds. Or, perhaps they should? Or even ought to? How can one change the world if one identifies oneself with everybody? How else can one change it?" (23).

This shift from "us" to "them"- Rubashov previously thought of himself in terms of belonging to the regime - occurs simultaneous to his attempts to restore his sensory abilities. As Rubashov begins to recover the capacity for individual thought, memory, and imagination, he yearns for the return of his senses of sight and sound, yet the former remains blocked in the traditional sense: he looks outside his cell window but only "feel[s] the cool glass on his forehead" (23). Yet this inability "to see" is saliently replaced with a renewed ability to hear: "Gradually, he became conscious of a small but persistent ticking sound in his cell" (24). At first, this hearing is muddled (24). The novel suggests that Rubashov must re-learn how to hear, must re-learn the signifiers for meaningful sound. ${ }^{114}$ Through a trial-and-error mode in which Rubashov teaches himself the meaning behind various tapping sounds, a new language unto itself, he learns that No. 402 is the source of the tapping and begins to respond in kind.

Rubashov establishes a new model of sensory language here through which aural knowledge can be acquired. This language operates entirely outside the regime's metaphysical control while still within a space of its physical domination. In the initial tapping exchanges, Rubashov does

\footnotetext{
${ }^{114}$ This abstraction of images, forcing the viewer to re-learn the seeing process, later becomes most evident in postwar experimental filmmaking, particularly Stan Brakhage's goal in Mothlight for his viewer to see images as if for the first time, as if infants emerging from a womb. See Brenez and Martin for further explanation.
} 
struggle with a complete abandonment of the mode established by the regime, for even as he learns to control his own aurality, he remains trapped by its bodily logic. He continues to "keep an eye on the spy-hole" and at one point "rub[s] his pince-nez on his sleeve" and goes "slowly, with tired steps, to the door and look[s] through the spy-hole into the corridor" (24-25).

All the while, Rubashov's "deafness" is never referenced during his conversations with No. 402. It is as if this former deafness, defined in relation to the form of "hearing" controlled by the regime, is no longer part of the sensory vocabulary established through Rubashov's reconstituted capacity for hearing. In fact, sensory restorations become mutually exclusive as Rubashov cements his new ability to hear and speak through the repurposing of his pince-nez. Here, the glasses become a political fetish object in the novel through which the oscillations of human evacuations and recoveries are played out in the prison cell. Rubashov begins tapping with his pince-nez in order to communicate with No. 402, and in so doing gives new meaning to sight, sound, and speech. Rubashov's recovered hearing appropriates a symbol of his role in the regime - the pince-nez — and turns that object once symbolic of controlled sight into one of free sound. Through his tapping, Rubashov first significantly restores meaning to his own name- he identifies himself by his distinct name rather than by a dehumanizing number. Like the act of speaking a name, Rubashov renames himself through his recovered ability to hear. Prior to his imprisonment, "Rubashov's experience had been so far confined to countries in which ... the members of the Party, for conspiratorial reasons, knew each other only by their Christian names - and changed even these so often that a name lost all meaning" (25). However, in tapping Rubashov renames himself completely: "He tapped out his full name: NICOLAS SALMANOVITCH RUBASHOV" (25). The recovery of Rubashov's "hearing" here is twofold: it establishes a human dialogue with No. 402 - speaking and listening - in a manner uncontrolled 
by the Party, but also reinstitutes the borders of individual identity with the tapped "utterance" of Rubashov's name.

Given the physically intense act of communicating through an encoded dialogue resembling Morse code, the act of tapping also implies a primitive form of bodily recovery. ${ }^{115}$ In retraining his hands to "speak," Rubashov begins to surpass the spatial limitations of the prison cell, designed to control the human body. ${ }^{116}$ Correspondingly, the discourse with No. 402 begins to trigger Rubashov's memory of events prior to the regime - the very thing that totalitarianism, according to Arendt, seeks to destroy. Here, the novel opens itself to two distinct possibilities for human dialogue: that with another, but also that with oneself through memory and imagination. ${ }^{117}$ The latter ultimately suggests a unique relationship between an individual and his power for memory while trapped within the enclosed spaces of tyrannical regimes. Dialogue between Rubashov and No. 402 provides an initial catalyst for Rubashov's memory. When No. 402 questions him about the woman he last slept with, "Rubashov rack[s] his brain. An old prewar song [comes] to his memory, which he had heard as a student .... He signed resignedly and tapped with his pince-nez: SNOWY BREASTS FITTING INTO CHAMPAGNE GLASSES" (29). This act of memory spontaneously sparks Rubashov's capacity for imagination, suggesting that the two may be closely intertwined. Whereas Rubashov initially assumed that No. 402 tapped "probably with some hard object such as a pencil" (24), as the conversation between the two men continues, Rubashov begins to imagine No. 402 repurposing his own eyeglasses, as well. Although Rubashov cannot physically see No. 402, he begins to imagine that, like himself, No. 402 "tapped obstinately with his monocle" (30). In this way, Rubashov's repurposing of the

\footnotetext{
${ }^{115}$ For an example of how such physical and psychological restoration occurred within the conditions of a North Vietnamese prison, nearly thirty years after the Moscow Trials depicted in Koestler's novel, see Borling.

${ }^{116}$ See, for example, Foucault.

${ }^{117}$ See Wollheim, who suggests that, similar to one's access to self-as-Other through memory and imagination, a self/Other relationship can be created through dreaming.
} 
totalitarian devices that control sight, and the coinciding recovery of his sense of sound, becomes partially restorative for other victims of the regime. It is as if the dialogue between Rubashov and No. 402, combined with Rubashov's increasing power for memory and imagination, has the ability to restore No. 402's human senses of sight and sound.

This conversation between Rubashov and No. 402 challenges the Arendtian language of radical isolation, as both characters begin to show human capabilities outside those proscribed by the regime, alongside a lessening of their complete and total isolation. Arendt's work focuses on the human deprivations inherent in totalitarianism that culminate in a final stage of succumbing to the regime, where dialogue with oneself proves to be a marker of the complete evacuation of humanity. However, Koestler's novel suggests that a dialogue with oneself - in the present and in memory's past - may demonstrate an ultimate method for recovering the human condition. Darkness at Noon proves a complex intertwining of dialogism, imagination, and memory that complicates Arendt's central assumptions.

Rubashov's restoration of his bodily senses results in the salient power of remembrance and imagination. As soon as Rubashov recalls the pre-war song, No. 402 begs to hear more of this "memory." This dialogue between them ultimately sparks Rubashov's intimate memory, which proves essential for the reconstitution of one's sense of morality and conscience from inside the walls of a totalitarian prison. No. 402 begs, "GO ON_PLEASE, PLEASE . . . PLEASE—PLEASE . . . MORE—PLEASE, PLEASE . . . TELL ME MORE—PLEASE” (30).

In "hearing” No. 402 and engaging with his pleas, Rubashov's imagination is incited. He not only visualizes No. 402's physical appearance and his use of his monocle as a tapping device, but he also imagines No. 402's positioning in the cell: "Perhaps he was kneeling on the 
bunk with his hands folded — like the prisoner in No. 407 had folded them to receive his piece of bread" (30). But more significantly, imagining No. 402 kindles Rubashov's own memory, which overtakes their dialogue both in its plot and in its past-tense narrative form. Here, Rubashov establishes a precedent for memory behaving as dialogue: the interaction between a present self and a past self in memory simulates a self-Other relationship. Just after picturing No. 402 kneeling with folded hands, Rubashov returns to a personal memory:

And now at last Rubashov knew of what experience this gesture had reminded him - the imploring gesture of the meager, stretched-out hands. Pieta ... Pieta ... The picture gallery of a town in southern Germany on a Monday afternoon. There was not a soul in the place, save for Rubashov and the young man whom he had come to meet .... It was in the year 1933, during the first months of terror, shortly before Rubashov's arrest (30$31) .{ }^{118}$

Even Rubashov acknowledges his newfound ability to remember his past. "Since the Pieta had occurred to him," he muses, this memory "[had] not surprised him; he was well enough acquainted with the day-dreams of imprisonment, with the intoxication which emanates from the whitewashed walls" (49). He realizes, however, that a "strange thing" about his so-called Pieta daydream is that "he had thought of the past; chronic prison day-dreamers dreamed nearly always of the future - and of the past only as it might have been, never as it actually had been" (50). Rubashov's memory is conspicuously anomalous for the totalitarian prisoner. While a meaningless "daydream" might afflict one's mind, Rubashov instead enters into a dialogue with himself in the past - an Other- through the act of remembering.

Further dialogue with No. 402 incites Rubashov's increased imaginative and evocative capabilities. Referring to another prisoner near Rubashov's cells, No. 402 sends the message:

\footnotetext{
${ }^{118}$ This scene is marked as a flashback not only by reference to Rubashov's prior arrest, but also by his use of the pince-nez: after leaving the museum in which he met the young man, Richard, Rubashov got into a taxi and "looked at [the taxi driver] attentively through his pince-nez. He was certain he had not seen that face before" (48). Also relevant is Rubashov's repetition of "Pieta." While his presence in an art museum conjures an image of the Virgin Mary supporting the dead body of Christ, the Italian translations also are salient: pity, mercy, compassion.
} 
"HARE-LIP SENDS YOU HIS GREETINGS" (57). Immediately, Rubashov begins to imagine the prisoner Hare-lip: "He saw in his mind's eye the yellow, upturned face of the man: the message made him feel uncomfortable” (57). ${ }^{119}$ In response, Rubashov taps, “WHAT IS HIS NAME?" and No. 402 answers, "HE WON'T SAY. BUT HE SENDS YOU GREETINGS" (57). Flashbacks subsequently flood Rubashov's mind: "Memories overwhelmed him; they hummed and buzzed subduedly in his ears. Faces and voices came up and vanished; wherever he tried to hold them they hurt him; his whole past was sore and festered at every touch" (58). He then "saw himself again in the old Belgian port, escorted by merry Little Loewy, who was slightly hunchbacked and smoked a sailor's pipe" (60). Rubashov's memory of Little Loewy extends to his surroundings, ripe with sensory recall: "He smelled again the smell of the harbor, a mixture of rotting seaweed and petrol; he heard the musical clock on the tower of the old guildhall, and saw the narrow streets with overhanging bays" (60). Here, the recovery of Rubashov's humanity comes full circle. Not only is he able to think and to remember, but he also is to take part in imagining the physicality of others whom he has known. In his first flashback, he does not describe the physical appearance of Richard, the young revolutionary. However, in this second one, Rubashov actually imagines Little Loewy and his full surroundings.

Although no objective proof exists to substantiate Rubashov's memory, the acts of remembrance and imagination alone prove significant. While envisioning another often proves objectively impossible, Elaine Scarry argues that merely "wishing to imagine" makes us "capable of recovering, of 'recognizing' the material world and distinguishing it from our

\footnotetext{
119 The adage of the "mind's eye" now replaces Rubashov's physical eyes as he begins "seeing" anew through the process of thinking. This phrase is repeated generously throughout the novel in connection with Rubashov's pincenez tapping (the repurposing of a "seeing" device) and his flashback memories with subsequent pangs of conscience. For example, as he begins questioning the validity of the Party's logic, "[a] picture appear[s] in his mind's eye” (59).
} 
imaginary world, even as we lapse into and out of our gray and ghostly daydreams" (283-84). It is this recovery of the material world that re-ascribes humanity both to he who imagines and to he who is imagined. ${ }^{120}$ This metaphysical human excavation repeats itself as Rubashov's memory of Little Loewy is layered with that of Bogrov: "He could not call back to his memory the visual image of Bogrov, but he saw the outlines of his gigantic figure, his awkward, trailing arms, the freckles on his broad, flat face with the slightly turned-up nose" (142). ${ }^{121}$ This has implications for the restorative literary power of a protagonist such as Rubashov, but also for those whose imaginations and memories are reactivated through reading. Almost as Rubashov can engage in dialogue with a remembered self, the novel also presents a possible "Other" in a symbiotic dialogue with its reader. This representational connection shows itself in the oscillations of purported judicial language, which I will examine through a reading of transcripts from the so-called Moscow Trials. While named to imply a legal legitimacy, the trials dangerously thwarted traditional notions of justice, placing men on trial for crimes they did not commit and forced confessions for those named crimes.

\footnotetext{
${ }^{120}$ Scarry discusses the difficulty of imagining others as a key tenet of the inability to establish human rights norms: "When we speak in everyday conversation about the imagination, we often attribute to it powers that are greater than ordinary sensation. But Sartre's study of the imagination shows more honestly and accurately that the opposite is the case. When we are asked to perform the concrete experiment of comparing an imagined object with a perceptual one - that is, of actually stopping, closing our eyes, concentrating on the imagined face or the imagined room, then opening our eyes and comparing its attributes to whatever greets us when we return to the sensory world - we at once reach the opposite conclusion: the imagined object lacks the vitality and vivacity of the perceived .... It is [at this point] when we are soaked with the longing to imagine that we notice, as Keats confessed, 'the fancy cannot cheat so well as she is famed to do,' By means of the vividness of perceptions, we remain at all moments capable of recovering, or 'recognizing' the material world and distinguishing it from our imaginary world" (282-84).

${ }^{121}$ For an explanation of the restorative potential and psychological limitations of imagination, see Sartre, The Imaginary. Remembering Bogrov and his individual features leads Rubashov to imagine Bogrov's demise. While Bogrov's death signifies the terror upon which the regime is constructed, Rubashov also uses Bogrov's liquidation to reinvigorate his "acoustic memory" (145). Although "the optic image was less sharp," Rubashov "hears" Bogrov calling out his name in memory, and then returns to his own private memories of Arlova (145). "Up till now," we learn, "he had never imagined Arlova's death in such detail. It had always been for him an abstract occurrence; it had left him with a feeling of strong uneasiness, but he had never doubted the logical rightness of his behavior" that ultimately led to her death (145). However, "[n]ow, in the nausea which turned his stomach . . . his past mode of 'thought' [that supported the regime] seemed lunacy" (145).
} 


\section{Reading the Moscow Trials: Literary Language and Biopower}

Totalitarian threats to dialogism and the recovery of the human body show themselves in the very language of the 1938 Moscow Trials. The transcripts from these trials adhere to a recognized legal form: the prosecutor presents the indictment prior to pleadings and witness testimonies, and at last a verdict is rendered. Yet the transcripts provide a salient lens into the problematic salience of juridical form without equal attention to substance. Such a distinction points to the "show" quality of these trials. At once, they take the shape of an adversarial process: they look like one and their transcripts include the legal terminology that establishes such boundaries. However, the content of the proceedings reveals a display of power over speech and body. As I will show, the trials demonstrate the regime's power over the contours of trial testimony, language faculties, and corporeal integrity.

Almost immediately following the trials themselves, the Soviet government translated the proceedings into English and packaged them as books for Western consumption. ${ }^{122}$ For the 1938 "Case of the Anti-Soviet Bloc of Rights and Trotskyites," an English-language edition of the proceedings published by the People's Commissariat of Justice of the U.S.S.R. began circulating in the United States that same year. This translation opens with a disclaimer: "This is a translation of the verbatim report of the proceedings of the Military Collegium of the Supreme Court of the U.S.S.R., March 2 to March 13, 1938 ... [T]his volume contains a communication for the press approved by the President of the military Collegium of the Supreme Court of the U.S.S.R.” This epigraph of sorts seeks to emphasize veracity in the proceedings; the

\footnotetext{
${ }^{122}$ The 1938 English-language edition included no materials extraneous to the court proceedings and the Soviet publication information. However, a second edition was published in 1965 in New York, "edited, and with notes, and with an introduction, by Robert C. Tucker and Stephen F. Cohen" (Tucker \& Cohen viii). The preface to this second edition explains its Cold War-era "need" in America, as the "record of the most important of the purge trials of Stalin's time should be made available to a wide public because it continues to have great relevance to basic political and intellectual problems of our age - in particular, the problem of totalitarianism" (viii).
} 
transcripts are coming to the West in a true and complete form. But the very language betrays a larger concern with the form, borders, and boundaries of an objective adversarial process while subordinating subjectivity, multivalent meanings, and the acquisition of knowledge. The Court's indictment and examination of Bukharin in the Anti-Soviet Bloc of Rights and Trotskyite trials provides a brief introduction to the legal language of these proceedings and its relation to the larger political and literary questions in this chapter.

A series of repetitions introduces the reader to the trials. For each of the sixteen "accused" persons, the Soviet President inquires, "have you received a copy of the indictment," to which each accused responds, "I have" (1-3). The President then questions each defendant, "do you desire to have Counsel for Defence," after which each of the accused answers, "No" (34). While the questions and answers themselves create a discernable form in their repetition, both the defendants waiting to respond and the reader (or listener) of these transcripts develops a mode of rote learning in relationship to the trial that thwarts legal comprehension or meaning. The shape of this legal dialogue looks like an adversarial process in which both the President and each of the defendants retain equal power to influence the outcome of the trial. However, through the repeated question-answer form, the response phrases lose meaning. Each defendant follows another, expected to respond with a simple "I have" or a "No," yet for each defendant, this act of responding signifies a different experience that is omitted from the procedure. Every response is layered with individual experiences that have led to each defendant's individual indictment and decline of counsel. As well, each reply contains within it the content initiated by the regime, reproduced with each repeated "I have" and each "No." The reader ultimately also becomes implicated in this mimetic act, "knowing" the forthcoming dialogue before attempting 
to process it. ${ }^{123}$

This early establishment of judicial language without meaningful content grows into the state's subordination of individual subjectivities in favor of a singular objective truth. The court seeks to control both the speech of the accused and the Russian language itself by denying the multivalencies inherent in subjectivity. This type of control functions as a method for foreclosing linguistic meaning outside that stipulated by the government, and it collapses the borders of subjectivities so that only a singular, totalized state remains. During his interrogation, Bukharin insists upon subjectivity as Vyshinsky, the state examiner, pushes back:

BUKHARIN: .... You, of course, would prefer to hear that I consider myself a spy, but I never considered myself a spy, nor do I now.

VYSHINKY: It would be more correct if you did.

BUKHARIN: That is your opinion, but my opinion is different.

VYSHINKY: We shall see what the opinion of the Court is (390).

Here, Vyshinsky does more than subordinate Bukharin's opinion to that of the Court- he denies its existence and in so doing insists on an objective state-approved "opinion." An opinion, subjective by its very definition, is forced into a position of singular objectivity. This destruction of language becomes clearer with questions of testimonial translation and diction in Bukharin's prior testimony:

VYSHINKY: "I asked Tomsky how the mechanism of the coup was visualized ... . He said that this was the business of the military organization, which was to open the front to the Germans.

BUKHARIN: Yes, correct.

VYSHINKY: Did Tomsky agree with this, or not?

BUKHARIN: He said "Was to" ("dolzhna"); but the meaning of these words is "müssen" and not "sollen."

VYSHINSKY: Leave your philology aside. In Russian "was to" means "was to."

....

VYSHINKY: Is that what you told him: "The front must not be opened"?

BUKHARIN: Yes.

\footnotetext{
${ }^{123}$ Such repetition conjures Rubashov's reference to "the tone and rhythm of the screams" of torture, a certain poetics of violence (Koestler 16). See also Reznikoff, questioning such a poetics in its use of IMT Nuremberg transcripts to assemble Objectivist poetry.
} 
VYSHINKY: But where is this written?

BUKHARIN: It is not written, but it is self-understood.

VYSHINKY: And what does playing on patriotic slogans mean?

BUKHARIN: The word "play" here was not meant in an odious sense.

VYSHINKY: "Was to" is not meant in its right sense, and "play" is not meant in its right sense.

BUKHARIN: "Was to" in Russian has two meanings.

VYSHINKY: And we want to have one meaning here (392-93).

Vyshinsky strips language of content here through an insistence on objectivity. By its nature, the practice of language assumes a dialogism through which it is constantly subject to changing signifiers and objects depending on the identity of the speaker. Language resists singularity, and by asserting it, Vyshinsky and the Soviet court begin the process of language destruction ${ }^{124}$ and, relatedly, the possibility for human speech and dialogue. Thus in abolishing the multivalencies of language, the Soviet state ultimately asserts its power over the human bodies on trial.

This assertion of biopower shows itself fully as the Soviet court marks the connections among the shapes of trial, nation-state, and body. In its indictment, the tribunal's language is expressed in nation-as-body terms, focusing on the defendants' provocation of "a military attack by [other] states on the U.S.S.R. [and] dismembering and severing from it the Ukraine, Byelorussia, the Central Asiatic Republics ....” (5). This corporeal description invokes an image of primitive bodily integrity and the desire to prevent its fracture, yet it also reveals a pejorative show of the nation's power over the body. The trial ultimately uses judicial form to display governmental power over the bodily integrity of the anthropomorphized Soviet Union. And in turn, such power over the physical borders of the Soviet Union imply an equal, if not amplified, power over those residing within it. Rather than exhibit a juridical control, the "show" trials prove more encompassing as they display a state power over the shape of the trial process, the form of language and communication, and the human capacity for speech and bodily

\footnotetext{
${ }^{124}$ To read Vyshinsky's insistence on objectifying language as a metaphysical act of torture, see Scarry's discussion of language destruction, or the denial of speech, that arises from acts of torture.
} 
integrity. In each case, identifiable forms remain while Soviet assertions of objectivity collapse the borders of subjectivity.

\section{The Politics of Narrative on the Brink of World War}

Narrativity in Darkness at Noon consists of blurred boundaries between subjectivity/objectivity and self/Other. Yet even at a moment of deepening political horror and an ongoing totalitarian threat, Koestler's protagonist recovers a self-consciousness and reestablishes individual subjectivity by learning to think through the Other. In so doing, he restores content to the "I." At its start, the novel already is immersed in pastness; by its opening in flashback form, death and human destruction condition our understanding of the novel. Yet at the same time, the varying narrative depths of history to which Koestler attends reinscribe the boundaries of personal history and identity while allowing for the reemergence of a meaningful self-consciousness once stifled by totalitarian collectivity. Here, I argue that Koestler uses literature to depict a reconstitution of the metaphysical margins of the self that have been eroded by varying collapses of objectivity and subjectivity. I begin by examining theoretical models of form and content, metaphysical self-consciousness, and the restorative power of reading conceived by Jean-Paul Sartre and Julia Kristeva. By relying on an atemporal, third-person narration in which flashbacks come to define Rubashov's personal history, I turn to questions of narrative in Darkness at Noon and contend that Koestler turns "History," an entity abused by the Party, into an ultimately healing force: "History will rehabilitate you, thought Rubashov" (13).

Theoretical models seek to explain the existence of a content-less "I," or the "grammatical fiction" to which Rubashov refers early in the novel. We might also think of this in terms of a literary methodology for both destroying and reconstituting self-consciousness, and 
the potential for a dangerous collapse of self/Other and the borders of individuality as a result of totalitarianism. These issues play out in Koestler's novel, and reflect upon literary theory in the immediate postwar years. In fact, both Arendt and Kristeva construct philosophical and psychological origin stories for the dangerously enclosed collective content-less identities of totalitarianism, while Sartre contends that reading practices can force such a collapse. ${ }^{125}$ A brief account of these models will help to illuminate the stakes of self-consciousness, the distinctions between form and content discussed in relation to Arendtian logic, and the possibilities for human recovery in Darkness at Noon.

Sartre and Kristeva approach distinctions between form and content and between self and Other in seemingly disparate ways. Yet a pairing of their literary philosophies alongside Koestler's novel generates startling connections between the powers of literature and the creation and reestablishment of self-consciousness. While a challenge to Arendt's political philosophy illuminates the possibilities of corporeal restoration in the totalitarian prison cell, the literary analyses of Sartre and Kristeva might help to shape our understanding of the literary distinctions between form and content at work in Darkness at Noon. In his critical exploration of the works of Jean Genet, Sartre contends that certain novels can lead to a literary experience in which form takes precedent to content. Strikingly, the substance of Genet's novels ultimately becomes subordinate to their form; the act of reading them is not intended to produce information about plot and character, but rather the distinct knowledge that evil is omnipresent. For Sartre, Genet's works "reveal the irreducibility of Evil" (493). This notion allows for an interesting tie to twentieth-century literature written in the throes and aftermaths of totalitarianism and World War II.

\footnotetext{
${ }^{125}$ See Kristeva and Sartre for differing perspectives on the origins of self-consciousness and trends toward violence.
} 
Although Koestler's work differs markedly from that of Genet, Sarte's analysis of Genet's texts has significant implications for the nature of individuality and self-consciousness in Darkness at Noon. In considering the questions of innocence and guilt in Koestler's novel, ideas of evil are challenged, as Rubashov is both a perpetrator and victim of the Soviet system. Once a high-ranking Soviet official, Rubashov has been imprisoned for crimes against the state, shifting from the role of the perpetrator into that of the victim. Yet, the novel's conception of evil is not a binary one, and restorative justice doesn't occur through traditional justice mechanisms; the Soviet system is one in which true justice has been made impossible. Instead, through acts of memory and imagination, as I have argued previously, Rubashov acquires an internal knowledge of guilt and the nature of the evils perpetrated by the system that in turn allow him to recover a facet of the human condition. It is only in the recovery of corporeality and memory that Rubashov finds an internalized psychological recovery in which he can think outside the system; he finds recovery as both (former) perpetrator and victim. This recovery sets up significant questions of the restoration of Rubashov's self-consciousness and the metaphysical bounds of the self. Sartre connects questions of self-consciousness and limits of evil to the practice of reading, implicating both character and reader in processes of human evacuation and recovery.

Sartre suggests that the novel as a form has the unique ability to elucidate the banality of evil, as it forces a collapse between a criminal protagonist and an innocent reader; the capacity for evil resides inherently in both but can readily be exposed through the act of reading. Herein also lies a certain power of literature as a restorative tool:

Lawyers, judges and psychiatrists see all that is visible and only what is visible: they comprehend crime in its objectivity, but its poetry escapes them. Genet begins his work where they leave off. Without rejecting their explanations, he discovers and reveals, over and above the facts, the poetic reality. He tells us that he is going to rehabilitate criminals .... To rehabilitate means, for Genet, to attribute poetically to a gratuitous and luxurious will to do evil what sociologists and psychiatrists present as the result of a 
determinism (492).

The novel's potential to embody a form that can produce such knowledge of evil establishes a link between the authority of literature and the law. ${ }^{126}$ Sartre implies that literature can take an active role in both stripping meaning from language and working to restore it, as I discussed earlier in reference to Darkness at Noon, thus further complicating the Arendtian distinctions between form and content.

That restorative power shows itself in the interplay between literature and law, and foregrounds the novel's rehabilitation of a novel's character, which transpires as the irreducibility of evil is exposed. Here, Sartre draws connections between reader and character in the act of self-consciousness restoration. The reader is implicated in the character's recovery, and this occurs as the reader, originally identifying himself as distinct from the protagonist, comes to see himself in that Other. The reader ultimately becomes unable to distinguish between himself and an Other (in Sartre's readings, the "Other" is none other than the author himself, Genet). In Sartre's reading, Genet begins this process with the presupposition of a reader who considers himself an "innocent," an "average Frenchman who adorns himself with the name of good citizen" (494). Sartre explains that, upon the reader's initial engagement with a Genet novel, he first believes that he recognizes himself as Other to the author/protagonist:

The Just man is so good at playing innocent that he gets caught up in his own game: evil

\footnotetext{
${ }^{126}$ The title of this essay itself attempts to draw a connection between the literary and the legal: "On the Fine Arts Considered as Murder." This language is expounded as Sartre describes Genet's literary template as having the recognized power of law: "It is with words that Genet will lay his traps. Words are the matter and weight of the soul ... The trap is a book" (495). Sartre further plays with this relationship when describing the "criminal" content of Genet's novels. "Crime is the major theme of his works," he writes. "[A]ll the other motifs twine round this black marble, like the queens round the pimps" (485). Sartre follows this observation with a comparison between actual crime and literary crime, or, as the essay's title betrays, "the fine arts considered as murder." In Genet's novels, "[e]verything [criminal] is present: the officiant, a corpse in effigy, everything but the blood. A fake murderer who has really been sentenced to death haughtily confesses, from the top of the scaffold, to his crime. All of Genet's books ought to be called "Execution capitale"-in every sense of the term" (485-86). The moment Sartre describes Genet's novels as themselves acts of capital punishment, the translator makes clear that Sartre intended to play with the often layered meanings characteristic of legal and literary language: "The term execution capitale means 'capital punishment.' But the author is suggesting that it can mean 'major work' as well (486).
} 
thoughts remain foreign to him since, by definition, they are the other's thoughts; he encounters them with sad astonishment in the course of his experience and recognizes them precisely by the fact that they are Other, by the fact that he would not have had the indecency to conceive them (495).

Yet, the reader responds by creating his own thoughts about what he is reading. In this creative act, Genet traps the reader in a situation in which the line between self and Other, or reader and Genet, has been eradicated. Interestingly, this theory also implies a link between acts of imagination and restoration that occur in the process of reading a novel like Darkness at Noon. While Sartre reads a pejorative conflation between self and Other, his analysis also opens a space in which the reader might rehabilitate Rubashov through the act of reading Darkness at Noon, while it also carries important implications for the literary distinctions between form and content.

Sartre explains further how this might work. A reader, he suggests, first conceives of his own thoughts about evil as markedly distinct from it. "As for the thoughts that spring up in his own mind," he writes, "they are self-evidently good: they have a transparency, a familiar and simple goodheartedness that inspires confidence at once. In short, he does not know what Evil is. He must learn about it from life" (495). However, an author like Genet will "avenge himself," as Sartre describes, by applying the "lex talionis" ${ }^{, 127}$ to his reader (495). This works as Genet "make[s] that innocent [reader] discover the Other in himself; he will make him recognize the Other's most improper thoughts as his own; in short, he will make him experience with loathing his own wickedness" (495). Such "[p]oetic traps will captivate his freedom and will reflect it to him as being half his own and half alien. He will be forced to see himself and will be

\footnotetext{
${ }^{127}$ It is interesting that Sartre chooses to use this phrase here. While understood to refer to the law of "eye for an eye" often cited in religious contexts, the Latin phrase also invokes the positive-law notion of proportionality in retributive justice, or mirror punishment. Thus, at once Sartre connects the literature of Genet to both restorative and retributive justice; Sartre first discusses Genet's ability to rehabilitate the power of literature and the criminal character, but then Sartre pulls into literary form the legal impulse toward proportionality. The use of a term translatable as "mirror punishment" also serves as a double entendre; in addition to referring to criminality and forms of justice, here Sartre also creates an image in which the self, looking toward the Other, sees only himself reflected back.
} 
able neither to recognize himself nor reject himself" (495). At this point, the content of Genet's novels has been rendered subordinate to their form; the significant feature is their distinct ability to institute a collapse between self and Other (or reader and protagonist) in such a way as to recover the criminal protagonist's humanity while simultaneously depriving the reader of his presumed innocence, thus illuminating the irreducibility of evil. Though this theoretical positioning also ascribes a distinct power to the reader: in order for Genet's form to produce its intended effect, the reader must pick up his book and engage in dialogue with its pages. Dialogue produced between reader and text with regard to Genet's novels is mimetic of the relationship between a Darkness at Noon reader and the novel itself. Both empower the literary texts and their readers, establishing a form of dialogism that can impact, destroy, and ultimately restore the borders of self-consciousness and individual identity.

For Sartre, this dialogue is dependent upon a first-person narrator; the reader comes to recognize himself in the Other through the form of the "I". He explains that, "regardless of who the writer is, when the sentence starts with 'I,' a confusion rises in my mind between this 'I' and my own" (498). This form of narration is specific to a written work of literature that requires the practice of reading: "No doubt if I saw the other person, if I saw the words come out of his mouth, I would relate his speech to his person. But I am alone in my room, and if a voice somewhere utters the words that I read, it is mine; in reading, I speak in the bottom of my throat and I feel myself speaking. At the present moment, in this room, there is only one man who says 'I,' to wit, myself. Caught in the trap: since, in order to understand the sentence, I must relate the 'I' to a subjectivity, it is to my own that I refer" (498). ${ }^{128}$ In this way, the reader reestablishes a

\footnotetext{
${ }^{128}$ Sartre explains further through example: "That is the way in which a reader of novels spontaneously identifies himself with the character who is telling the story ... 'I was afraid; I ran down the stairs': that is all that is needed to endow us with an imaginary past; we have the feeling of gradually recalling the events of a bad dream; little by little someone familiar yet unexpected emerges from the mist: a person suffering from amnesia starts remembering
} 
self-consciousness through direct engagement with the Other, and this reestablished individual identity is one that both restores the evildoer Other - the criminal protagonist - to a state of neutrality and confirms the self's individuality while simultaneously substantiating the irreducibility of evil in the material world.

Working in a psychoanalytic vein, Kristeva also seeks to understand the beginnings of self-consciousness, or arising distinction between self and Other, and to explain how the desire to maintain this distinction can yield radical prejudices and totalitarian impulses. Both works bear upon questions of individual self-consciousness at play in Darkness at Noon. Like Sartre, Kristeva locates this impulse in the literary. Both identify a relationship between the author, reader, and text that illuminates the ways in which self/Other distinctions becomes realized and blurred; Sartre's analysis relies on the hyper-sexual works of Genet, while Kristeva's draws on the anti-Semitic novels of Celine. But while Sartre imagines this relationship as one in which the self becomes Other, Kristeva conceptualizes novels as staging grounds for the formation of a hyper-distinguished self/Other boundary that she terms the abject. In literature, the commingled "author and reader" can perform a pejorative creation of self-consciousness (in which the Other is hyper-othered) to prevent this dangerous action outside the literary context. A threat of the confluence of objectivity and subjectivity forces the self to strive against such a collapse. In so doing, the self begins to establish a hyper-subjectivity, one whose borders become sharply defined in relation to all others. He seeks to avoid abjection by marking himself as a unique "I," objectively distinct from any Other. Literature, she argues, can interpret and purify the abject; through writing and reading practices, the ever-presence of the abject in daily life can lessen or

things, the members of his family relate to him his past actions, and, as they begin each story, he wonders anxiously: "What else did I do?'” (498-99). 
cease. $^{129}$

The practice of literature functions as a "catharsis, or purging of the abject and thus a renewed recognition of what is 'other' to oneself' (Kristeva 71). In this way, certain novels can be read as a "working through" of abjection. Kristeva contends that, as an example, Celine relied upon anti-Semitism in his written work to "keep from going mad" — such anti-Semitism provided him with a form of subjective security in which his identity, regardless of other identifying tenets, remained a negated yet objective one: not Jew. Referring to Celine's adherence to Nazism, Kristeva argues that,

"[as] ambivalent and paltry as that action was, is not one that can be explained away. It becomes integrated as an internal necessity, as an inherent counterweight, as a massive need for identity, a group, a project, a meaning; thus it crystallizes the objective and illusory reconciliation between, on the one hand, an ego that drowns in the whirl of its objects and its language, and, on the other, the identifying prohibitions - an unbearable, untenable, disintegrating one, which causes him to be" (136). ${ }^{130}$

In this Kristevan view, a sharply differentiated literary relationship between self and Other also retains a very real power, as it can be the only thing that prevents the realization of prejudices founded upon the distinguishing borders of selfhood. This process also can lead to a specific narrative form marked by the increasing presence of the abject in a world marred by the growth of totalitarianism.

Kristeva also defines narratology in the mid-twentieth century and afterward as

\footnotetext{
${ }^{129}$ Importantly, Kristeva makes clear that the abject never recedes entirely. It remains in the conscience even following attempted literary excisings, threatening to blur the border between self/Other. It is a fear of this border dissolution, Kristeva argues, that "keeps the subject vigilant of the abject" (136).

${ }^{130}$ Kristeva clarifies how Celine's anti-Semitism specifically allowed him to ensure his identity as "not Jew": "His fascination with Jews, which was full of hatred and which he maintained until the end of his life, the simple-minded anti-Semitism that besots the tumultuous pages of the pamphlets, are no accident; they thwart the disintegration of identity that is coextensive with a scription that affects the most archaic distinction, that bridges the gaps ensuring life and meaning. Celine's anti-Semitism, like political commitment, for others-like, as a matter of fact, any political commitment, to the extent that it settles the subject within a socially justified illusion - is a security blanket. A delirium, to be sure, but one whose social unfolding and multiple rationalizations are well know; a delirium that literally prevents one from going mad, for it postpones the senseless abyss that threatens this passing through the identical, which is what scription amounts to" (136-37).
} 
excavating an author's grappling with the ever-presence of the abject. Narrativity no longer can consist of linearity and causality ${ }^{131}$ such structures inherently are destroyed by the existence of the "suffering-horror" of world war and totalitarianism. She further contends that "when narrated identity is unbearable, when the boundary between subject and object is shaken, and when even the limit between inside and outside becomes uncertain, the narrative is what is challenged first" (141). These questions of literary form created amidst the ongoing threat of totalitarianism in the East and a world poised on the brink of war resound in Koestler's fiction. While Darkness at Noon often challenges the modes of narrativity and the establishment of selfconsciousness to which Sartre and Kristeva refer, its narrative structure is marked by a newness of form, perhaps as a result of the political conditions under which it was written.

Writing before the outcomes of Nazism and Stalinism were known, Darkness at Noon enables theoretical conceptions of form and content in the novel, positing literature as an active staging ground for the reconstitution of self-consciousness and individual identity as the threat of totalitarianism looms large. The Sartrean and Kristevan approaches to the novel illuminate ways in which fiction can greatly impact the borders of self-consciousness and the lines between self and Other. At the same time, they establish reading practices and conditions in which the novel, as a work intended to be read, relies on the reader to have full effect and realization of character self-consciousness and restoration. Koestler's novel tragically traces Rubashov's grappling with the blurred borders of self-consciousness and his reacquisition of an individual identity as his

\footnotetext{
${ }^{131}$ In the Kristevan view, postwar literature's linearity is constantly threatened by its inherent politics. She writes of literature that attempts such linearity: "If it continues nevertheless, its makeup changes; its linearity is shattered, it proceeds by flashes, enigmas, short cuts, incompletion, tangles, and cuts. At a later stage, the unbearable identity of the narrator and of the surroundings that are supposed to sustain him can no longer be narrated but cries out or is decried with maximal stylistic intensity (language of violence, of obscenity, or of a rhetoric that relates the text to poetry). The narrative yields to a crying-out theme that, when it tends to coincide with the incandescent states of a boundary-subjectivity that I have called abjection, is the crying-out theme of suffering-horror. In other words, the theme of suffering-horror is the ultimate evidence of such states of abjection within a narrative representation" (141).
} 
death is made imminent. In so doing, Darkness at Noon engages with real-world victimhood and criminality, while it proposes a restorative capacity of character self-consciousness in literary acts of memory and imagination.

Koestler's novel stages a new kind of emerging self-consciousness: an "I" that must be re-formed amidst the "self"-eroding aims of Stalinist communism. It presupposes the meaningless existence of an "I" — or a "grammatical fiction" — and the presence of a totalitarian regime that has relied only on its form to establish a process by which the self/Other collapses into an amorphous collective, exposing various points of Kristevan abjection. The grammatical fiction exemplifies the ways in which totalitarianism strips human content from an individual, leaving only a human form without its substance, yet it also typifies the resulting "formless mob" of Party members following the collapse between subjectivity and objectivity. This mob takes the shape of a loyal following but lacks the significant ideological content inherent in any Arendtian "true believer."

The novel's epigraph demonstrates the double-edged sword of consciousness under Stalinism. In order to engage literature in an active role of totalitarian resistance, Koestler himself is forced to collapse individuality to a point at which he can discuss collective victimhood: "The characters in this book are fictitious. The historical circumstances which determined their actions are real. The life of the man N.S. Rubashov is a synthesis of the lives of a number of men who were victims of the so-called Moscow Trials. Several of them were personally known to the author. This book is dedicated to their memory" (vii). Here, the novel stages a reconstitution of self-consciousness from within a political space that denies the existence of individuality. Koestler writes that, in Stalin's Soviet Union, "the members of the Party, for conspiratorial reasons, knew each other only by their Christian names - and even 
changed these so often that a name lost all meaning" (25). Koestler turns this presupposition on its head as the single name of his protagonist, Rubashov, ultimately gives substance and individual consciousness back to a collective victimhood.

While the epigraph portends a text about the life of a protagonist, N.S. Rubashov, the novel begins in third-person flashback form, indicating a need to return to a past in which Rubashov is still alive, while also signaling the reader's placement in relation to Rubashov. The novel's narrative is premised upon the blurred and ever-shifting borders created by totalitarianism: of the self, of nation, of time, and of history. The novel begins immersed in pastness through flashback, reported from an uncertain future by an unnamed narrator. Our introduction to Darkness at Noon begins in past tense, with Rubashov in second- and thirdperson grammatical form: "The cell door slammed behind Rubashov. He remained leaning against the door for a few seconds and lit a cigarette" (1). He is depicted in past tense, in a previous moment; from the current point of narration, Rubashov no longer exists. This initial scene conditions our understanding that the text will provide an explanation for the eventual execution of Rubashov, immersed in totalitarianism and on the brink of world war. ${ }^{132}$

The narrative enacts the erasure of personal history through flashback, as the third-person form betrays a fragmentary past with salient omissions. As readers, we have access to Rubashov only in the second- and third-person form, and just as Rubashov describes the "I" as a grammatical fiction in the novel, the "I" remains equally inaccessible for the reader. Narrative flashback is not dependent upon Rubashov's memory or the relationship he creates between his present and former self, which ultimately enables him to reconstitute the borders of a present-

\footnotetext{
${ }^{132}$ See Brooks' Reading for the Plot for a nuanced analysis of the connection between narrativity and pastness.
} 
tense "I."."133 These blurred borders of chronology continue as the novel progresses. Early on, we go back further in time - “an hour earlier" - to learn the events surrounding Rubashov's arrest from the third-person narrator's point of view. The narrative alludes to his past but omits subjective memories of experience. Rubashov senses that he "was already in that peculiar state of excitement" produced by the "nearness of death" (12), but this remains an objective account. Even when his former experiences of imprisonment are described in detail, they remain objective: "He had marched up and down his cell, and crawled over the flagstones of the dark punishment cell, and when cold water woke him from unconsciousness, he had groped for a cigarette and gone on lying" (60-61). The absence of Rubashov's subjectivity is literalized in dialogue. After he is denied bread being distributed to other prisoners, Rubashov demands to know, "Why was I omitted?" (20).

The novel questions how self-consciousness re-arises after omissions and attempted destructions. In Darkness at Noon, Koestler reconstructs boundaries of individual identity by a twofold process: Rubashov first learns to think through the Other, thereby enlivening his own imagination and a reconstitution of the borders between individuals, followed by Rubashov's ability to remember his past, thus allowing the reconstruction of his own identity. In so doing, he recreates fixed borders of national and individual history, as well as of self. Koestler's narrative form reconstitutes the boundaries of both consciousness and time/space destroyed by the regime.

The move toward thinking through another begins as Rubashov recounts how Soviets have been instructed to avoid sympathy and empathy; unique individual traits and emotions

\footnotetext{
${ }^{133}$ Such borders are exactly what totalitarianism seeks to destroy, to reveal the Kristevan abject: "On close inspection, all literature is probably a version of the apocalypse that seems to me rooted, no matter what its sociohistorical conditions might be, on the border where identities do not exist or are barely so-double, fuzzy, heterogeneous, animal, metamorphosed, altered, abject" (Kristeva 207).
} 
cannot further the revolutionary cause. He recalls "the old disease" of understanding, and recalls that "revolutionaries should not think through other people's minds" (23). However, Rubashov then questions the validity of this protocol (23), which brings about the beginnings of his reconstructed self-consciousness. Although as yet fully unaware of himself as individual, he becomes aware of "a small but persistent ticking sound in his cell," through which he ultimately will have reconstituted himself in body and mind, as I argued previously (24). In questioning the process of thinking through another, or as another, Rubashov recognizes the existence of individual identity and self-consciousness, even within the totalitarian prison.

His recognition of these margins of individual consciousness also revitalizes his imagination. Unique to his individual thoughts and ideas, Rubashov's imagination ultimately allows him to think as another. Whereas he once thoughtlessly followed the plans of Soviet leader No. 1 -Stalin's thoughts are everyone's thoughts—Rubashov begins to view the prisoners alongside his cell as thinking individuals. Considering prisoner No. 402, Rubashov wonders, "[w]hat went on in his heart?" (55). He later imagines No. 402's thoughts in whole: "Probably he was thinking, I gave it to you all right. Probably also: Canaille, how many of my people have you shot?" (55). Ironically, the content of Rubashov's imagination matters less than its shape here-Koestler allows form to amelioratively take precedence over substance in order to begin the process of self-consciousness recovery.

This imaginative ability comes to a head when Rubashov is interrogated by Ivanov, his former comrade in the revolution and now-turned prison official. Here, Rubashov not only thinks as Ivanov, but his imagination also supports empathy: he sees and feels as Ivanov. At the beginning of their interaction, Rubashov identifies a newly awakened, yet "thoroughly tangible component in this first person singular," which induces his "compulsion to think through the 
minds of others" (110-11). The narrator details this scene, in which Rubashov "sat in Ivanov's place and saw himself through Ivanov's eyes, in the position of the accused, as he had once seen Richard and Little Loewy," two former Party members (111). By imagining Ivanov's thoughts and feelings, Rubashov engages in an act of thinking that reconstructs individual borders between Ivanov and himself, as well as between himself and the individuals in his past whom he formerly recalled in "either/or" terms: either party members or party enemies. ${ }^{134}$

In addition to the dialogue between Rubashov and No. 402 discussed previously, Rubashov's reconstructed imagination and his subsequent moments of thinking through the Other also induce flashback sequences - memories of men and women once dismissed merely as Party enemies, whom he now has the imaginative capabilities to see as individuals. In so doing, he begins to reconstitute his own self-consciousness, remembering himself and others in unique detail, as opposed to merely as self/Other. It is here that Rubashov's relationship to himself in the past, or himself as Other, becomes a salient tool in his ability to recover his own selfconsciousness. The literary power of memory grows palpable as the substance of Rubashov's humanity reemerges in his acts of remembrance and imagination. In the literary present, he recalls himself as he was in the past, and he acquires new knowledge from such encounters. For ultimately, it is Rubashov's attempt to imagine the Other that restores certain borders of individuality within a regime that threatens the collapse of self-consciousness.

A shift occurs in the flashback mode as third-person narration is replaced with Rubashov's first-person memory. The initial flashback sequence of the novel is interrupted by a flashback within another. This narration restores historical boundaries both for the Party and for

\footnotetext{
${ }^{134}$ Prior to engaging in acts of memory, Rubashov's capacity for imagination also was beleaguered. Recalling his thoughts prior to Arlova's execution, Rubashov muses: "When a year ago he had sent Arlova to her death, he had not had enough imagination to picture the details of an execution. Would he now behave differently merely because he now knew some of its aspects?" (Koestler 157).
} 
Rubashov. In memory, Rubashov locates a scene specifically in 1933, in "the picture gallery of a town in southern Germany on a Monday afternoon" (31). While previously situated in an amorphous time and space, the flashback establishes a spatial and temporal border, grounding the memory in time and space, and thereby denying the totalitarian impulse to erode such borderlines. Accordingly, the mode of narration shifts again as Rubashov recalls speaking in the first-person singular, thus establishing a unique "I" for himself (35).

In the narrative moment at which Rubashov's death is imminent—-the point from which the novel presumably begins-Rubashov has reestablished an understanding of the separation of body and mind, an imagined borderline between objectivity and subjectivity. After retreating into a past through which he could recreate the outlines of self and Other, Rubashov's execution nears. Feeling physically shaky, he notes that "above, it is possible to kid oneself, but below, from the stomach downwards, one knows" (186). His subsequent "confession" traces out the shift from the objective stance of the Party to his subjective "guilty" pleas. Rubashov speaks as a conscious entity against the Party line and completes the restoration of self-consciousness by learning physically how to "dot his 'I" (226). Whereas his "handwriting during the last few days had borne a somewhat flabby and unsteady character," it "again became firm and disciplined" (174). Here, Rubashov's personal history can reach a narrative end, as he has reached a conclusion founded upon shared human empathy:

The sole object of revolution was the abolition of senseless suffering. But it had turned out that the removal of this second kind of suffering was only possible at the price of a temporary enormous increase in the sum total of the first .... Was such an operation justified? Obviously it was, if one spoke in the abstract of 'mankind'; but, applied to 'man' in the singular ... the real human being of bone and flesh and blood and skin, the principle led to absurdity (259-260).

Rubashov inscribes this reestablished principle for humanity in abstraction, finally restoring content to the conceptual form that the Party's principles take. 


\section{Conclusion}

In sum, a radical revision of the way in which we read Koestler's Darkness at Noon yields both literary and political payoffs that have significant implications for the connections among literature, law, and restorative justice. This rereading ultimately reveals the multifaceted possibilities for human recovery within a totalitarian system. It evinces immense complexity with regard to the powers of the human condition, offering both a nuanced conception of humanity that exceeds its limited historical treatment and a challenge to Arendt's restricted understanding of the role of the individual within a tyrannical regime. Speaking to the injustices enacted at the actual Moscow Trials in 1938, Koestler's novel stages moments of human strength that the trials deny: corporeal restoration, sensory recovery, and the reestablishment of individual identity and self-consciousness. In so doing, Darkness at Noon invents a mode of literary restorative justice that envisages the recovery of this forgotten novel from its politically charged entanglement with Nazism, Stalinism, and the Cold War, while it also imagines the bodily and metaphysical reclamations of the self amidst the totalitarian threat of human evacuation. 


\section{Chapter Two:}

\section{Remaking the Historical Record: Remedies for the former Yugoslavia and Aleksandar Hemon's The Question of Bruno}

I could not initially comprehend what Karadžić meant by 'annihiliation.' I groped for a milder, less terrifying interpretation-perhaps he meant 'historical irrelevance'? I could settle for historical irrelevance, whatever it meant. What he was saying was well outside the scope of my humanist imagination, prone to reveries and fears; his words extended far beyond the habits of normalcy I desperately clung to as war loomed over what Sarajevans called 'common life.'

-Aleksandar Hemon, The Book of My Lives

Arising out of the violence during the Yugoslav Wars, Aleksandar Hemon's first novel The Question of Bruno (2000) depicts a particular geopolitical history of violence. ${ }^{135}$ A text

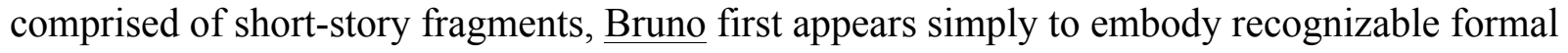
trends of postmodern fiction. Yet the textual fractures of Hemon's novel speak directly to the contested national and ethnic borders of the Balkans, inscribed and repeatedly remapped across the twentieth century. In the early 1990s, the siege of Sarajevo forcefully displaced Bosnian citizens like Hemon, removing them to "nowhere spaces," as the author calls them. ${ }^{136}$ In effect, many became emigrants without a home country or an adopted one. These harms were not the first to afflict residents of the Balkans, however. Decades prior, the wounds of World War II and Tito’s subsequent communist politics erased Yugoslavia's known national and ethnic histories. The siege of Sarajevo added yet another trauma to existing fractures. Hemon's novel raises new

\footnotetext{
${ }^{135}$ Aleksandar Hemon, The Question of Bruno (New York, Farrar Straus, 2000).

${ }^{136}$ For a discussion of the "nowhere" spaces from which the subaltern writes, see Walter Mignolo, Local Histories/Global Designs: Coloniality, Subaltern Knowledges, and Border Thinking (Princeton, Princeton UP, 2000).
} 
questions about how to heal these palimpsestic wounds, speaking to similar concerns that lie at the center of the International Criminal Tribunal for the former Yugoslavia (ICTY).

From Sarajevo, Hemon arrived in Chicago in 1992, where he applied for political asylum and began learning literary English. He has described his need for English-language knowledge as necessary to contend with his displacement on American soil: "I was cut off from my previous life, in despair .... I had this horrible, pressing need to write because things were happening. I needed to do it the same way I needed to eat, but I just had no language to write in. I couldn't do it, and so I thought I should enable myself to do it." ${ }^{137}$ Hemon suggests that authorship has the potential to remedy political wounds. Not surprisingly, much of his fiction, including Bruno, is tinged with autobiographical impulses. But his work moves beyond the mere healing power of literary creativity, of the act of storytelling. ${ }^{138}$ Instead, his novels attempt to piece together larger histories of his homeland lost to human rights violations. All the while, he marks them with the injurious fractures of geopolitical violence; for Hemon, histories can be recovered, but they will always bear fragmentary traces of past harm. He describes this authorial process as "fac[ing] history with language." ${ }^{\prime 139}$ This approach to literature raises important questions about the methods and forms of justice available to Anglophone fiction and judicial venues.

Traditionally, international criminal tribunals aim to effect retributive justice, or to punish perpetrators. Bruno depicts new possibilities for restorative justice, the counterpart to the retributive, that speaks directly to international human rights law. Hemon's text engages with legal matters of testimony and witness in the aftermath of political trauma, and it demonstrates how a dialogic relationship between a novel and a reader can play a key role in human recovery.

\footnotetext{
${ }^{137}$ Larry Rohter, “Aleksandar Hemon's Twice Told Tales: Displaced in America,” New York Times, May 15, 2009.

${ }^{138}$ For a discussion of the healing power of creativity, see Melanie Klein, Love, Guilt, and Reparation (London, Hogarth Press, 1981).

${ }^{139}$ Aleksandar Hemon, introduction to Garden, Ashes (Chicago, Dalkey Archive Press, 2003).
} 
Established scholarship on law, literature, and trauma provides a necessary framework for my contention. Specifically, trauma studies models show the healing potential of subjective testimony, and the ways in which a reader of literature can bear witness to trauma. Recent scholarship in world literature and human rights has proposed a scenario in which a reader might become part of a community that imagines and enforces human rights. Building on this work to expand its reach to restorative justice measures in the courtroom and to key features of legal remedy, I argue that Hemon's novel, approached in direct relation to the aims of the ICTY, can provide us with new knowledge about the distinct relationship between law, literature, and the practice of reading.

First, Bruno teaches us that contemporary political traumas, when layered upon already existing historical ones, produce persons and communities that cannot be "made whole" as remedy law conceives. Given that fragmentation becomes an inherent condition of being in certain regions of the world, remedial methods must take into account these fractures and acknowledge that they stand outside traditional legal approaches. Next, and more significantly, Hemon's novel depicts a relationship between reader and text that can broaden the restorative potential of the tribunal system. Bruno shows us how imaginative literature can provide a necessary subjective counterpart to the "historical record" created in an international criminal court. This is not to suggest that the legal practice can be reduced to mere objectives and literature to broader, subjective elements. Rather, I contend specifically that the novel helps to develop the form of historical record-making created by the tribunal, thereby expanding global understanding of geopolitical violence and encouraging victim healing through increased knowledge. Providing supplemental evidence to promote recovery, the novel acts in concert with the tribunal to seek a fuller form of justice. Moreover, Bruno proves that the novel can in 
fact lengthen the temporal boundaries that constrain the work of the tribunal. While the ICTY must abide by its temporal mandate, a historical record created through a dialogic interaction between reader and text can proceed well beyond the years of trial. Indeed, as I will show, Hemon's reader can continue to construct the historical record of violence in the former Yugoslavia with each reading of the novel.

In this chapter, I begin with a brief survey of current scholarship in law, trauma, and human rights that provides a theoretical foundation for my argument. The next section explores models of fragmentation in "Islands," the story that opens Bruno, and explains how this distributed form of writing stands in opposition to traditional conceptions of legal recovery. This reading offers an analysis of the inherently fragmentary nature of the trauma tied to the Balkans-Hemon's pages themselves are marked by textual "wounds." The third section considers distinctions between legal and literary rhetoric, asking how we might write the juridical-political discourse that lies at the heart of the tribunal and becomes integral to Hemon's imaginative fiction. Does the literary open avenues for reimagining modes of human recovery? Here, I detail changes in ICTY Rules and Procedures that reduce testimonial storytelling, and thus the creation of a full historical record. Considering these restrictions of the international justice system while acknowledging its potential, the following section looks to "An Exchange of Pleasant Words," asking how translation affects identity politics while producing a distinctly literary record of emigration. I move then to a consideration of "A Coin," arguing for a new kind of literary human wholeness as political violence threatens the irreparable disruption of time and space. Here, the trauma is at once static, but also constant and ongoing. The final section looks to "The Life and Work of Alphonse Kauders" to argue for a restorative function of humor. This story engages with issues of serious play and playful seriousness, creating a space for irony 
within a traumatic past. It provides an alternate record that makes violence knowable, and thus manageable, through the political joke. Ultimately, Hemon's novel recasts our conceptions of restoration and redefines the reader's role in formulating new possibilities for reconciliation.

\section{Trauma, Human Rights, and Literary Studies: A Critical Background}

Can the novel imagine a different mode of literary restoration that addresses the law's

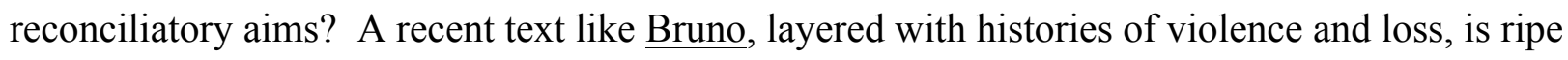
for asking new questions about reparation for those wounds. As I mentioned, the Balkans have suffered from the injuries of World War II, the merged and eradicated national borders of Tito's communist state, and the harmful ethnic divides made salient during the breakup of the former Yugoslavia in the early 1990s. Caryl Emerson suggests that literary fragmentation can be linked directly to Central and Eastern European novelists as a result of the systemic violence in the region over the years, forcing citizens to migrate across frequently shifting national borders: "Exile, displacement, multilanguagedness, heteroglossia, outsideness to oneself and thus a taste for irony, the constant crossing of borders, and the absence of a tranquil, organic, homogenized center that belongs to you alone: these ... virtues and prerequisites for genuine dialogue have long been endemic to Central Europe." ${ }^{140}$ Emerson implies that inherent qualities of brokenness are not pejorative ones that might place Bosnians outside the boundaries of recovery, but rather features that enable literature to draw attention to the complicated history of this region and to invent new models for human restoration.

Designed to punish and repair the harms arising from the Yugoslav Wars, the ICTY recognizes a victim's right to a remedy. Specifically, it emphasizes the importance of restitution,

\footnotetext{
${ }^{140}$ Caryl Emerson, “Answering for Central and Eastern Europe,” in Haun Saussy, Comparative Literature in an Age of Globalization (Baltimore, JHU Press, 2006), 203-04.
} 
reparation, and rehabilitation. ${ }^{141}$ Yet the law's remedial focus on "making whole" a victim presupposes a completeness of personhood, one that has been broken at a specific point in time through an identifiable wound. As I will show, Hemon's text displays the impossibility of such a wholeness, thereby standing in opposition to traditional legal conceptions of remedy. It is a text that makes salient the quality of division and palimpsestic existence; $\underline{\text { Bruno }}$ is a polyphonic novel that can only be told in segments. Discussing his own writing, Hemon explained that "this multiplicity of possible points of identification is what constitutes a person" from the Balkans. ${ }^{142}$ His work conceives fragments as a given after political injury, and explains that a different form of restoration is needed to begin healing those wounds.

The juridical focus on victim wholeness appears to stand in stark opposition to the fractured condition depicted in Hemon's work. While traditional remedy law aims might prove inapplicable to certain persons, my reading of Bruno suggests that literary and legal inquiries actually can be bridged through attention to the specific aims of the ICTY and to the role of the global reader. Previous scholarship exploring the relationship between human rights, trauma studies, and literature can help us to think about the role of political trauma in fiction, and the possibilities for both literary and legal recovery. Earlier studies undertake questions that center on matters of witnessing and the problematic language of human rights - issues separate from actual legal praxis. Building on this work, I show how the novel can expand the healing encounter of bearing witness to a historical record immersed in multiple histories of ethnic violence. My analysis of Hemon's novel seeks to draw attention to the relationship between law

\footnotetext{
${ }^{141}$ See Basic Principles and Guidelines on the Right to a Remedy and Reparation for Victims of Gross Violations of International Human Rights Law and Serious Violations of International Humanitarian Law, G.A. Res. 60/147, U.N. Doc A/RES/60/147 (Dec. 16, 2005).

${ }^{142}$ Lania Knight, “A Conversation with Aleksandar Hemon,” The Missouri Review 32 (2009), 97.
} 
and literature that occurs at the very moment and to illuminate the fiction reader's role in enacting restorative justice.

A renewed attention in the early 1990s to psychoanalysis in literary studies temporally coincided with escalating violence in the Balkans and the eventual establishment of the ICTY. Specifically, Shoshana Felman co-authored Testimony: Crises of Witnessing in Literature, Psychoanalysis, and History in 1992 with clinical psychiatrist Dori Laub, a work that arose from the Holocaust. This critical text emphasizes the power of dialogic encounter in the process of bearing witness to human trauma. In short, bearing witness becomes a two-way encounter through which a victim tells her story to another who bears witness. The work imported a new kind of legal language into literary study that expanded restorative justice to spaces outside the courtroom. Indeed, this theoretical model establishes methods through which to assess the role that literature might play in reimagining terms of victim recovery.

Felman attends specifically to terms of "witness" and "testimony." In so doing, she emphasizes that, while these terms may traditionally be housed in the language of law, they are nuanced psychological processes that operate in contrast to the juridical notion of "creating a historical record" through witness testimony. ${ }^{143}$ While the trial might be the realm for establishing a set of facts, alternately, a dialogic encounter in which a speaker testifies to injury and a witness listens can promote healing; subjective experience, rather than objective truth, becomes central to recovery. ${ }^{144}$ In other words, bearing witness for the purpose of healing, rather than as a means to enact criminal retribution, stands in stark contrast to the creation of a legal

\footnotetext{
${ }^{143}$ Shoshana Felman and Dori Laub, Testimony: Crises of Witnessing in Literature, Psychoanalysis and History (New York, Taylor and Francis, 1992). Felman and Laub also emphasize the "contract" of testimony, or the "give and take" dialogism of the testimony that mirrors the language of "promise and performance" in contract law. Cathy Caruth frequently characterizes incidents of trauma as "breaches," acknowledging the language of contract law within literature and psychoanalysis, and suggesting that the fractures of trauma may in fact be inscribable into the language of law.

${ }^{144}$ Felman and Laub, 71.
} 
record of truth. It is the experience of recounting a subjective memory to another that helps victims to heal from traumas. Accordingly, objective facts become less significant than the act of giving testimony if we aim toward restorative rather than retributive justice. In fact, victims who give testimony frequently recount "facts" incorrectly, yet psychologists have found that they show signs of rehabilitation from the mere act of storytelling. ${ }^{145}$ Felman and Laub's work could be undertaken in a courtroom, yet it draws clear distinctions between psychological testimony intended to promote healing and legal testimony intended to produce objective fact; the two models inhabit separate spheres. Can this model help us to consider ways that a so-called historical record of truth might actually encourage both rehabilitation and criminal justice?

Notably, Felman addresses the unique role a literature reader can play in traumatic repair. As readers, we might act as Other to a fictional giver of testimony, thereby creating a dialogic encounter with the text. Together, a novel and its reader might perform the healing act of bearing witness. Such an idea ascribes a power to the act of reading and implicates us in the knowledge produced from a testimonial text. In effect, the novel becomes a living document, producing new forms of knowledge with each new reading (and witnessing). Anne Cubilie's recent trauma studies text, $\underline{\text { Women Witnessing Terror }},{ }^{146}$ speaks specifically of dialogic limitations in Bosnian texts. Cubilie contends that certain literature cries out, asking a reader to respond to its narrated moments of violence. The plea for such a dialogic encounter from this region, Cubilie suggests, makes salient the striking global access to knowledge of violence there. Unlike earlier human rights violations, ethnic cleansing in the Balkans was depicted across

\footnotetext{
${ }^{145}$ For instance, Laub describes a Holocaust survivor who had been imprisoned in Auschwitz and who, during testimony, described acts of resistance within the concentration camp. She remembered a series of chimneys being blown up in minute detail. Other historical records indicated that her memory had been faulty-the details she had given were objectively incorrect, describing the wrong number of chimneys-yet the power of the testimony, Laub contends, arose from the experience of giving it and having a listener to bear witness. See Felman and Laub.

${ }^{146}$ Anne Cubilie, Women Witnessing Terror: Testimony and the Cultural Politics of Human Rights (New York, Fordham UP, 2005).
} 
television screens worldwide. We might consider those newscasts as calls to viewers to bear witness. Such a relationship never arose. ${ }^{147}$ Yet the novel, unlike a newscast, can provide an individual relationship with each reader from which a dialogic encounter might arise.

Indeed, scholarship concerning human rights and literature has alluded to an ameliorative role for the reader in the face of political violence. Discussing the relationship between the novel and the creation of human rights language, Joseph Slaughter's Human Rights, Inc. implies that a reader can enact a metaphysical form of justice by engaging with a text. ${ }^{148}$ Can the practice of reading having a direct political effect? Jacques Ranciere's work speaks to this claim, suggesting that such a relationship might be a useful one to conceive. ${ }^{149}$ To be enacted, he implies, human rights require third-party action from an outsider separate from the rights seeker. ${ }^{150}$ Slaughter builds on this idea and depicts a human rights community in which the reader, through dialogic encounter with the novel, might come to play the role of an outside third party who can enforce the law (or, at least, help us to imagine how an outsider might do just this). Yet, a disconnect remains between legal praxis and literary encounter. My reading of The Question of Bruno contends that the reader does indeed play a unique role in healing trauma. However, it takes a different angle into the human rights community that Slaughter describes to imagine a form of remedy that speaks directly to the aims and limitations of the ICTY.

By its very definition, trauma is imbued with images of fracture and apunctuality. For instance, Ruth Leys explains that, in a Freudian model, trauma always emerges after an initially

\footnotetext{
${ }^{147}$ Susan Sontag, Regarding the Pain of Others (New York, Macmillan, 2003). See Sontag for a discussion of the limited relationship between a viewer and a subject of violence.

${ }^{148}$ Joseph Slaughter, Human Rights, Inc.: The World Novel, Narrative Form, and International Law (New York, Fordham UP, 2009).

149 Jacques Ranciere, "Who is the Subject of the Rights of Man?" in The South Atlantic Quarterly 103.2/3 (2004), 297-310.

${ }^{150}$ Gayatri Spivak, "The Use and Abuse of Human Rights," in boundary 232 (2001), 131. My point is not that human rights create a power dynamic in which a third party gives the rights designed by a western nation to a member of a developing nation, as Spivak argues. Rather, the situation looks more like a legal "defense of a third."
} 
harmful event; it occurs only through a return to the initial suffering. ${ }^{151}$ But how can we bridge the psychological repair of these fractures with the necessary work of the tribunal system? Established views in law and literature that I've discussed lay the framework for a new intervention into the field. Specifically, Hemon's novel involves the reader not as a conversant witness or as an enforcer of human rights, but rather as a figure who can contribute material to the historical record begun at the tribunal, taking into account the inherent fractures in Eastern European identity.

\section{“Are We There Yet?": Narrative Fragmentation and Traumatic Memory}

As the first segment in The Question of Bruno, "Islands," sets out to identify the multitudinous fissures of 1990s Yugoslavia and the incomprehensibility of restoration to a point of wholeness or completeness, all bound up in a layered socialist past. The segment establishes qualities of multiplicity and fragmentation that characterize the novel itself. Here, Hemon defines his text as mimetic of its introductory segment: a series of literary islands that illuminate the impossibility of constructing a "whole" narrative, as his is inherently marked by physical and theoretical ruptures. By addressing the necessity of an island-like quality of testifying, Hemon illuminates questions concerning geographic, historic, and literary interplay to speak to the lived traumas in the Balkans and their reflection upon states of expatriation. At once, he points to an inability to restore the inherent gulfs among the "islands" to which he refers, yet in this recognition, he produces new knowledge about human recovery; when we ask different questions, we begin at a moment of dissolution and the impossibility of full reconciliation. If we start from this point of islanding - a position that neither implies a deconstruction nor a series of violent breaks from an original whole - we can pose new questions about the relationship among

\footnotetext{
${ }^{151}$ Ruth Leys, Trauma: A Genealogy (Chicago: U of Chicago Press, 2010).
} 
suffering, an inherently injured existence, and literary studies.

Through "Islands," Hemon thus asserts a multivalent definition of the term. He encourages us to visualize not just geographic entities, land masses cut off from one another through impenetrable fields of water, but also palimpsestic layers of national and individual pasts marked by deleterious omissions-island-like histories. In this way, the novel encourages a reading strategy that notes not only the physical text on the page and the significance of the physicality of the novel, but also the absences to which textual gaps refer and to the amorphous borders of geographic, temporal, and national spaces. As a result, Hemon also provides an interpretive methodology through which we are invited to approach this book not as a series of separate and distinct short stories collected in one volume, but rather as a novel, a "whole" unto itself, consisting of intentionally fragmented narratives. Each story can be construed as an "island": connected to each entity in the book's series, but marked by gaps in time and space.

Hemon first plays with the shifting spatial quality of islands through textual layout. Like geographically scattered, often amoebic land masses of differing sizes and shapes, his writing creates similar blocks of text, numbered 1-33 for identification, upon the pages of the story. These text blocks become pieces of a narrative marked by visual breaks that signify obvious omissions, much like island-land formations. At the same time, the distributed nature of these narrative pieces is checked by Hemon's numbering of each textual "island": while lacking borders and suffering from exclusions, these text blocks nonetheless clearly are demarcated as necessary entities in a different kind of chronological trajectory—one recording a history of European Socialism defined and marred by fissures and erasures. The numbered text blocks establish a form of narrative that is always-already fractured; by its very nature, "Islands" can only be told in this incomplete form. Visually, it contradicts the appearance of a narrative that 
was once whole and was later marred by rupturing traumas. Rather, the narrative begins at a point of incompleteness and depends upon the very broken quality of the geographic island.

The unique ability of these passages to deal with the inherency of fragmentation shows itself in the rather traditional trajectory of the story's plot. The first text block begins at the start of a new day: "We got up at dawn, ignored the yolky sun, loaded our navy-blue Austin with suitcases and then drove straight to the coast" (3). Accordingly, just as "Islands" begins with the start of a new day, it ends with the closing of a day: "It took us only four hours to get home from the coast and I slept the whole time, oblivious to the heat, until we reached Sarajevo" (21). While the story does not proceed as an entirely chronological or otherwise traditional narrative (the narrative is plagued by temporal gaps), it is still constructed through the familiar plot frame of a family traveling on vacation. The narrator describes a familiar "are we there yet?" travel dialogue: "I would ask my parents: 'Is this Mljet?' and they would say: 'No"” (4).

Yet embedded within the seemingly canonical plot devices are individual and familial histories of eastern European communism, which disrupt the more innocent story of a family outing. As soon as the young narrator sets off for the trip, both his mental and physical states are interrupted and damaged by the realities of communist Yugoslavia: "I sang communist songs the entire journey: songs about mournful mothers looking through graves for their dead sons; songs about the revolution, steaming and steely, like a locomotive; songs about striking miners burying their dead comrades. By the time we got to the coast, I had almost lost my voice" (3). Here, as the young narrator nears the coastal boundary — a border making clear the splinter of the landhe loses his ability to speak. Similarly, the living space of the vacation house is immersed in a constant visual reminder of a pejoratively watchful communist eye. One of the room's aural ambiences, "fragrant with lavender," is breached with a visual mark of repression, "a picture of 
Comrade Tito, smiling, black-and-white, on the opposite wall" (7). Even geographic spaces mimic Tito's constant watch: "Uncle Julius . . looked at the photo of Mljet and then put the tip of his finger at the point in the upper-right corner, near the twin lakes, which looked like gazing eyes" (20).

Relatedly, the vacation islands not only contain pieces of Yugoslavia's communist history, but also the repressive imprint of Stalin's prison camps, infamously coined through Solzhenitsyn's Gulag Archipelago. Just as geographic islands often are scattered yet still in close proximity to a larger nation-state, they are marked by a connection to "nation" while remaining disconnected by the ocean space between. In much the same manner, Hemon recognizes his characters as parts of a national whole, yet stained by their relationships to the often ambiguous national and historic identities in the Balkans. One of the few named characters in "Islands," the narrator's Uncle Julius, intertwines Soviet and Yugoslavian histories of oppression, linking together geographic entities that lack common borders and have temporally distinct histories. An amorphous character, Uncle Julius is steeped in conflicting identities, which is reflected on his person. He first reintegrates the physical past of the family's Yugoslavian island destination into the present, recalling that "there used to be so many poisonous snakes on Mljet that people used to walk in tall rubber boots all the time, even at home, and snakebites were as common as mosquito bites" (5). This recollection allows Uncle Julius to draw a connection between the palimpsestic socialist history of revolt: "But then the mongooses killed all the snakes and bred so much that the island became too small for them .... So that's how it is, he said, it's all one pest after another, like revolutions. Life is nothing if not a succession of evils" (6).

Marked by a lack of physical borders and a distinct national identity—Uncle Julius is 
described as being both Ukrainian and Bosnian, or perhaps neither - the narrator pinpoints the source of such amorphousness in "island" block number 13: "Uncle Julius told us that ... he was in the Arkhangelsk camp" (9). The narrator omits pieces of Uncle Julius's further remembrances, indicating only that "they sent Uncle Julius to a different camp, and then to another one, and he didn't even know how much time or how many camps he had passed through ...." (10). Such memory bears weight on the young narrator, who begins to question his own identity and the possibilities of marking out an "I" within a politically oppressive regime: "I'd be aware that my skin was the border between the world and me" (14).

Following this recognition, the trauma of a Yugoslavian history of forced collectivity and the multigenerational shifts in national identity force a change in the narrator's understanding of himself. Here, Hemon sets a foundation for the crux of restoration and human recovery to which he attends through the rest of the novel. The textual island blocks once framed by the narrator's "I" have been reframed through a collective (socialist) "we". Hemon once began several "islands" with such narrations as: "I clambered," "I lay on the bed," "I woke up", and "I went down the stairs" (6-12). However, as the narrator's sense of individuality within the geographic confines of Yugoslavia begins to erode, the borders of the textual islands are replaced by collective pronouns: "They sent Uncle Julius", "They took him", "We walked", and "we would sit” (14-21). A voice of individual narration slowly is disintegrated through the ever-present threat of collective space, in which the narrator eventually will lose the ability to discern first the material—followed by the psychological—self. The impossibility to discern an individual identity within the national and literary boundaries established in "Islands" sets the narrator on a course of recovery in the novel: of himself and his family's history within the oppressive regimes that have dominated the Balkans in the 20th century, but more significantly, the recovery of a 
knowledge of fracture that disrupts the traditional view of trauma and allows for a re-articulation of victim reconciliation based not on "making whole," but rather on the distinct production of knowledge from the "island."

Our narrator here returns to his childhood again in subsequent stories, yet the novel's substance grows increasingly concerned with the political climate in Yugoslavia. Considering all his losses, the narrator describes the whole of the novel's collection in metaphor, speaking to the interrelations among its many islands. "Most of this story is a consequence of irresponsible imaginings and shameless speculation," he confesses, but nonetheless reflects that "parts of it ... washed against my shores, having floated on a sea of history books, dotted with islands of blackand-white photographs" (91). The act of collecting this disintegrated familial past, which also comes to stand in for a history of fragmentation in the Balkans, has significant bearing upon the nature of historical recordkeeping and storytelling in the ICTY, which purports to collect and chronicle its own account of violence in the former Yugoslavia.

The novel begins strategically with "Islands." It lays out a terminology to address the disassembled self, specifically reimagining the always-already broken person as one linked to geopolitical upheaval rather than one theorized in philosophical discourse. It displays the border slippages inherent in nationhood, and the accompanying identity slippages of the self. Accordingly, Hemon paints an image of personhood that is inherently immersed in "nowhere spaces" and resistant to traditional notions of restoration. Within the liminal places created by political violence in the late 20th century, any notion of reconciliation must root itself in the terms of multiplicity and mobility. When boundaries of self-consciousness are not founded upon wholeness, how do we conceive of human recovery? Hemon introduces us to these terms in "Islands," and they are reflected in the discourse surrounding legal narrations of restorative 
justice. While legal rhetoric contains its own disciplinary nuances, its conception of traumatic narration in many ways forecloses possibilities for inscribing the boundaries of the disassembled self and thereby reveals the imaginative limitations embedded in juridical mechanisms.

\section{Interplaying Legal and Literary Rhetoric}

When boundaries of self-consciousness are not founded upon wholeness, how do we conceive of human recovery? Hemon's novel raises salient questions about the legal avenues available to victims of mass violence. In fact, the historical timelines of the ICTY and the publication of Bruno run parallel. As Hemon crafted fictional narratives depicting the fate of the former Yugoslavia, victims' advocates in the ICTY pushed for a section of the tribunal that would address the need for healing venues of storytelling and record-making.

Until 2000, the ICTY had no mechanism outside the courtroom through which to address issues of restorative justice alone. More than six years after its establishment, a donation from the European Union (EU) funded operational costs for a Victims Outreach Program at the tribunal's headquarters in the Hague. While this endowment was not strictly intended as an arm through which to enact reconciliatory measures, outreach program coordinators describe its function as a reprieve to the retributive trials [32]. In its current state, the program remains unfunded by the $\mathrm{UN}$ (unlike the trials and their related expenses), and victim outreach still is not considered a "core activity of the Tribunal."152 For many involved in the creation of the Victims Outreach Program, it came too late; within two years, the U.N. began amending testimonial rules and procedures that sharply limited focus on restoration.

But can we critique the tribunal for failing to do what it was not meant to do? It aims primarily to bring perpetrators to justice. However, while the statute creating the ICTY does not specifically require victim outreach, it has emphasized restorative justice goals. In particular, the mandate of the

\footnotetext{
${ }^{152}$ See Peter Finci interview.
} 
tribunal includes "contributing to restoration" in the Balkans, which is reflected in official materials distributed to visitors at the ICTY. Pamphlets explain that a primary aim of the tribunal includes "bringing justice to victims." More significantly, the tribunal records that it has given victims "a voice," having "provided thousands with the opportunity to be heard."153 The tribunal highlights that it has achieved another substantial victim-centered goal, as it has "established beyond a reasonable doubt many facts related to the crimes committed in the former Yugoslavia, thereby contributing to the creation of a historical record, combating denial and preventing revisionism." ${ }^{154}$ Yet, this assertion raises significant questions about the perspective from which such a history might be documented. Should it be a static one in which revisionism is necessarily a pejorative term? Here, Felman and Laub's analysis of testimony becomes particularly relevant. The ICTY language proposes only an objective record of fact, while Felman and Laub's work contends that subjective truths are necessary for healing. Can imaginative literature bridge these seemingly disparate ideas? Is it possible for a historical record to be multifaceted, much like Hemon's characters?

It is important to note that, unlike prior international criminal tribunals, the ICTY purports to seek justice that includes both punishing perpetrators and healing victims. Here, the genre of the novel might give voice to a complementary way of composing this legal-political discourse.

Similar to the ICTY mandates, Hemon's work seeks to address wounds arising from the former Yugoslavia. Yet legal rhetoric differs markedly from the literary, as the novel can contain multiple voices and tenses. This is not to essentialize legal discourse, however. I propose that the knowledge produced by the novel can work in conjunction with the legal to establish a multifaceted historical record that contains both objective histories of criminal acts, as well as varied individual traumas. Such a historical record, to be as complete as possible, must include both a legal record of agreed upon fact in

\footnotetext{
${ }^{153}$ Handouts given to visitors of the ICTY emphasize that the tribunals are convened in large part to restore dignity to victims of mass violence in the Balkans.

${ }^{154}$ See ICTY handout.
} 
addition to the subjective accounts that broaden the narrative of criminality and promote victim healing.

In a recent interview, Hemon indicated that he has "a hard time writing anything from a single point of view or having it in one discursive tone or voice." ${ }^{.155}$ Unable to write in his native Bosnian, his English-language work reveals a testimonial form inhabited by a "multiplication of personalities," as he describes it. Emphasizing the vicissitudes of experiential violence, Hemon describes literature as "the only thing that is capable of containing this simultaneity." ${ }^{156}$ When pressed to elaborate on the ways in which the novel might necessarily contain such polyphonous qualities, Hemon distinguished fictive literary histories from those in legal-political discourse, describing the former as ones "that you can enter into from various points. No single point of view is more relevant than another."157

Literature adds to the universe of knowledge established by judicial procedure, creating heteroglossia and establishing a form of legal-political testimony in which fragmented and subjective histories work in concert with the objective ones established by legal rhetoric. In encouraging his readers "to think of the narrative as having different but equally valid points of entry, different but equally legitimate points of view," Hemon frames his texts as those that might allow us to move from individual wounds to those of Yugoslavia contained within the tribunal transcripts.

Since Hemon's work may be read as an alternate, subjective history of Balkan violence, a deeper analysis of the legal mechanics concerning historical record-making can illumine the complex ways in which Bruno supplements the restorative justice work conducted at ICTY. I contend that the aims of the tribunal system — specifically the establishment of a historical record — might only be made complete by incorporating works of cultural imagination. As the ICTY nears its end, we can find numerous examples of how the tribunal has fulfilled its primary mandate to "bring to justice those responsible for serious violations of international humanitarian law committed in the former Yugoslavia." Yet the

\footnotetext{
${ }^{155}$ See Knight, 97.

${ }^{156}$ Ibid.

${ }^{157}$ Ibid.
} 
tribunal's restorative goals, including the establishment of a complete historical record, are left wanting. This lacuna exposes certain limitations of the tribunal system, but it also opens up the possibility that imaginative fiction can help us to see new ways of closing these gaps.

By its very nature, the ICTY and other similarly structured tribunals are limited to prosecuting specific acts. In practice, this means that the broad cultural and humanitarian damages inflicted during the Yugoslav wars are not crimes that can be prosecuted. Yet in its formative years, the ICTY was uniquely envisioned as a judicial venue with near-total "means of doing justice, deterring further crimes, and contributing to the restoration and maintenance of peace." ${ }^{\prime 158}$ To restore peace, the creators of the tribunal must have imagined a power broader than those set by the prosecutorial rules and procedures. But at the same time, the tribunal was endowed with "temporal jurisdiction," mandating that the Court only address crimes from a specific time period. ${ }^{159}$ In connection, the tribunal was given a clear "completion strategy" that required all trial processes conclude by $2004 .{ }^{160}$ In order to fulfill its completion target, the ICTY Rules and Procedure underwent several significant amendments that ultimately affected the amount of victim involvement at the tribunal. Specifically, the amendment of rules $89(\mathrm{~F})$ and 92 bis permit and, in some cases favor, the inclusion of witness testimony in written form. On a basic level, this reduces the presence of victims at trial and denies the dialogic "storytelling" power of their testimony that Felman and Laub find essential to healing traumatic wounds. ${ }^{161}$

Nancy Paterson, a former trial attorney at the ICTY, condemned these amendments.

\footnotetext{
${ }^{158}$ See First Annual Report of the International Tribunal for the Prosecution of Persons Responsible for Serious Violations of International Humanitarian Law Committed in the Territory of the Former Yugoslavia since 1991 to the Security Council and the General Assembly, UN Doc A/49/342-S/1994/1007 (29 August 1994), [First ICTY Report], 11.

${ }^{159}$ See Rules of Procedure, Art. 6,8

${ }^{160}$ UN Sec Council Res 1503 (2003).

${ }^{161}$ Rule 89(F) of the Rules of Procedure prescribes that "[a] Chamber may receive the evidence of a witness orally or, where the interests of justice allow, in written form," while Rule 92 bis further clarifies that "[a] Trial Chamber may dispense with the attendance of a witness in person, and instead admit, in whole or in part, the evidence of a witness in the form of a written statement ... in lieu of oral testimony." Former ICTY prosecutor Nancy Paterson argued that, while "the simple act of providing a forum for victims to tell their stories will not, by itself, restore and maintain peace ... it can move the process forward." See Nancy Paterson, "Silencing Victims in International Courts," Georgetown Journal of International Affairs (2003), 99.
} 
Underscoring the ICTY's subordination of victim needs in response to the increased urgency of completion, Paterson emphasized that "[w]ar crimes trials must address the needs of three key parties: the perpetrators, the victims and the community affected by the war. To accomplish this, the court must find a way to help the victims accept, understand, and verbalize what has happened to them. The victims must be given an opportunity to articulate and visualize their experiences. Anger and sadness have to be expressed in a public arena." 162 She focuses on the language of the ICTY mandate to "contribute to the restoration and maintenance of peace." It is important to remember that the ICTY set goals beyond those traditionally ascribed to criminal prosecution--specifically, its language about restoration. Given that the tribunal now is nearing completion, is it possible to still account for restorative justice, fulfilling these additional aims of the tribunal?

In response to Paterson's critique, Nancy Combs's innovative work on guilty pleas looks to legal procedure to imagine a mode in which the retributive trial system can lend itself to restorative potential. ${ }^{163}$ Her seminal model takes into account the often anti-rehabilitative outcome of a court's focus on retribution. But more importantly, it opens up a legal space to enact alternative models of restorative justice. Combs thinks about human recovery within the procedural powers of the tribunal system, taking into account the speediness mandated by its completion strategy. In this way, her work differs markedly from that of Felman or Slaughter, who focus on literary potential outside the trial space. Combs argues that guilty pleas specifically can produce a courtroom that simulates a truth and reconciliation commission, thereby promoting victim healing and closure.

Three key features of her model include "truth-telling, victim participation, and reparatory obligations." 164 She arrives at these contingents by looking to the Truth and Reconciliation Commission

\footnotetext{
${ }^{162}$ See Paterson, "Silencing," 99.

${ }^{163}$ Nancy Combs, Guilty Pleas in International Criminal Law: Constructing a Restorative Justice Approach (Stanford: Stanford UP, 2007).

${ }^{164}$ Ibid, 9.
} 
(TRC) used in South Africa, identifying its salient qualities: "Truth commissions provide victims with an opportunity to relate their stories to a sympathetic audience and, in the process, create a historical narrative of the suffering. In general, these truth-telling and reparatory mechanisms advance goals that criminal trials either ignore or underemphasize." ${ }^{\prime 165}$ In achieving these goals, Combs's model would advance restorative principles while also promoting prosecutorial retributive aims. Her theory creatively maneuvers within the international justice system by translating the preexisting domestic model of the guilty plea to the international criminal arena. Yet it overlooks inherent limitations in such a system, most notably the directive for the law to "make whole" its victims through testimonial storytelling and to attend to objective documentation.

Current trends in the ICTY reflect its limited ability to use guilty pleas to supplement the restorative justice lacuna in the courtroom. Legal practitioners, including Combs, insist upon the creation of an historical record made possible by a guilty plea (a perpetrator who pleads guilty must provide a full accounting of his or her crime), highlighting its ability to provide victims with of justice through truth and knowledge. In practice, however, such an undertaking remains incomplete. This problem is particularly salient in the face of guilty pleas at the ICTY, underlining the need for alternate thinking about victimhood and restoration.

A recent case at the ICTY highlights the problem. In Prosecutor v. Dragan Nikolic (2005), the defendant was charged with 29 counts of crimes against humanity in conjunction with his role as the camp commander in Sušica detention camp in Vlasenica. ${ }^{166}$ Under Rule 62 ter of the ICTY Rules of Procedure, Nikolic entered into a plea agreement that required his admission of guilt and an accounting of the facts of his crime in order to "bring the truth to light and justice to the people of the former Yugoslavia" (para. 122). According to the rules of court, the guilty plea would produce a clear record of

\footnotetext{
${ }^{165}$ Ibid., 6.

${ }^{166}$ See Prosecutor v. Dragan Nikolic, Para. 122, U.N. Doc. IT-94-2-S (2005). In fact, Nikolic was the first defendant indicted by the ICTY in 1994. It took more than ten years to convict him.
} 
the defendant's crime, which in turn could provide victims and their families with closure. However, Nikolic's Sentencing Judgment actually suggested the opposite. The court noted that, in such a plea agreement, "[n]either the public, nor the judges themselves come closer to know the truth beyond what is accepted in the plea agreement." In fact, the court emphasized that such a plea can result in "an unfortunate gap in the public and historical record of the concrete case" (para. 122). The court implied that guilty-plea sentencing has a primarily retributive aim and cannot produce historical knowledge: "[I]t should be recalled that this Tribunal is not the final arbiter of historical facts. That is for historians. For the judiciary focusing on core issues of a criminal case before this International Tribunal, it is important that justice be done and be seen to be done." 167

The tribunal's shift away from record-making came to the fore in subsequent cases where the tribunal omitted multiple narrations of criminal acts. In Prosecutor v. Lukic (2009), the defendant was charged with rape crimes. ${ }^{168}$ Before trial, additional victims came forward with subjective narrations of the sex crimes committed by the defendant. The court denied an amendment to include these added incidents of rape, as the objective elements - the facts evidencing that the defendant had committed the crime as defined by the statute-were already included in the initial charges. In other words, a crime that produced multiple narrations of violence was recorded as a single instance of criminality. To be sure, the court did not include the additional victims' stories in its historical record of fact (para. 1152). This case illustrates the limitations inherent in the tribunal's creation of history, and the need for a complementary approach to close the lacuna. The courts at the ICTY do not pretend to establish a complete and

\footnotetext{
${ }^{167}$ Nikolic, para. 122. See also Kupreskic et al., Para. 756, U.N. Doc. IT-95-16T (2000): "To be sure, the primary task of this Trial Chamber was not to construct a historical record of modern human horrors in Bosnia and Herzegovina. The principal duty of the Trial Chamber was simply to decide whether the six defendants standing trial were guilty of partaking in this persecutory violence or whether they were instead extraneous to it and hence, not guilty."

${ }^{168}$ Prosecutor v. Lukic, Para. 1152, U.N. Doc. IT-98-32/1-T (2009).
} 
total history of the former Yugoslavia, yet subjective testimonial omissions suggest that we need to explore additional possibilities for healing wounds inflicted by political violence. In "An Exchange of Pleasant Words," Hemon elucidates the novel's contribution to healing trauma by chronicling the past.

\section{Literary Recordkeeping: Unknowable Historiographies in Translation}

Steeped in the immense losses of homeland created by the Yugoslav Wars, subjective elements of testimony, witness, and truth come together in Bruno. Hemon's novel interrogates these matters in a distinctly literary mode: through the issue of translation. At a midway point in the novel, his narrator remarks of his story, "I'm translating it . . from memory," since he already "annihilated the notebook" that once held the written version (Hemon 82-83). The novel grapples with several conceptions of translation and loss that bear upon the legitimacy of memory as a form of historical recordkeeping, and as a tool for traumatic healing. Translation need not refer only to language, ${ }^{169}$ as Hemon's work develops a definition that concerns physical transformations of forced migration. The novel moves from a translation that merely turns "one language into another" to one that focuses on the movement of persons, and a physical "change in form, appearance, substance." ${ }^{, 170}$

Hemon's ethics of translation has its roots in a loss of individual and national identity. This speaks to Felman's work, which contends that language translation might function as an act of bearing witness. It illuminates, she argues, the traumatic ideological space in which the

\footnotetext{
${ }^{169}$ Walter Benjamin describes translation as a mode "not only for communication, but also for writing the history of a text. Walter Benjamin, "Task of the Translator," in Illuminations (New York, Schocken, 1968), 70-71. A subsequent essay explains that "every expression of human mental life can be understood as a kind of language .... [A]11 communication of mental meanings is language, communication in words being only a particular case of human language." Walter Benjamin, "On Language," in Reflections (New York, Schocken, 1968), 314.

170 "Translation," in Oxford English Dictionary, http://www.oed.com.proxy.its.virginia.edu/view/Entry/204844?redirectedFrom=translation\#eid, last accessed June $30,2013$.
} 
original was written. Accordingly, Felman suggests that translation can deconstruct a text by undoing illusory historical perceptions connected to its origin story - the place, time, and (national) space in which it was written. ${ }^{171}$ In Bruno, Hemon acknowledges these possibilities, but instead imagines translation in distinct relation to politics, and the limitations placed upon documentation and the memory of experience. Instead of examining a national or linguistic "original" made to be translated, Hemon departs from a point without origin; his novel dwells in "nowhere spaces" without ethnic and national borders - state of liminality inhabited by persons deprived of a nation.

As such, Bruno speaks to the limitations of a remedy aimed at making whole; political trauma has left Hemon's characters without an original wholeness that might be remade. Instead, the novel reconceives of literary translation in such a way that the reader becomes central to piecing together seemingly unknowable histories of violence. We might see that the reader enters into the international human rights community that Slaughter imagines in Human Rights, Inc., but instead the reader undertakes a different kind of reparative exercise. Hemon's reader plays a significant counterpart to the international criminal court, collecting and transcribing a different form of subjective historical record. In so doing, his reader acts in concert with the tribunal's goals, aiming to compile the personal and national histories destroyed by violence in the Balkans.

Hemon begins $\underline{\text { Bruno }}$ from a position of always-already in translation; his narrator, a Bosnian immigrant living in America, has already undergone a transmutation of personal, familial, and national form. The always-already qualifier naturally accompanies Hemon's characters, who have come to being and dwell within liminal spaces where knowledge of

\footnotetext{
${ }^{171}$ Shoshana Felman considers translation as an act of both bearing witness and deconstruction through a reading of the texts of Paul de Man. See Felman, Testimony, 122.
} 
familial and national identity is unknown. At moments in "An Exchange of Pleasant Words," Hemon's narrator flashes back to his childhood in Sarajevo and moves forward in time up to the start of the Yugoslav Wars, seeking to restore his knowledge of individual identity. At the same time, he aims to create a document that reflects the violence his family and nation have endured.

The narrator, in many ways a stand-in for Hemon himself, first seeks to inscribe his family's known history into written form to restore its material presence. Yet as he attempts to create proof of the "Hemon family" that transverses temporal and national boundaries, he marks the impossibility of his task. As such, we learn that it's not the substance of restorative that matters, but the recoveries acquired during the process. The narrator begins this process through a "translation from memory" - an attempt at recordkeeping, or a recounting of a family narrative that traces the roots of both his given and family names to a supposed nineteenth-century Western European familial relation:

In the fall of 1811, Alexandre Hemon got up from his slothful bed in Quimper, Brittany . ... We imagine him marching through Prussia, still stunned by the greatness of the world .... Then we see him charging at the ferocious Russians at Smolensk. At Borodno, he leads the infantry attack .... [T]here's no plausible explanation for Alexandre ending up in the western Ukraine, near Lvov. Certain factions in the family suggested that higher forces had had a hand in the miraculous (mis)placement of Alexandre (95-96).

This "miraculous misplacement" allows the narrator to come into being, a half-Russian, halfSerbian resident of Sarajevo. It is as if the Hemon file is not yet founded upon displacement, but rather misplacement; pieces of the family tree exist in their entirety, but have simply been miscategorized.

Yet the reliability of this information is called into question as the narrator further evokes elements of his history. When detailing Alexandre's battle wounds and the Bosnian woman, Marija, who tended to them, the narrator recalls that his Uncle Teodor "sometimes like[d] to add a touch of gangrene," a realization that leads to the narrator's admission that his family has "no 
well-established facts from which the questionable existence of Alexandre Hemon would necessarily follow" (96-97). This lack of evidence grows salient as the narrator recalls an incident during the 1984 Winter Olympics in Sarajevo. There, a rifle manager for the French biathlon team, Lucien Hemon, described their shared last name as "a rather common family name in Brittany" in a feeble attempt to flirt with the narrator's sister. This flawed fact, the narrator tells us, "was the germ from which Alexandre sprung" (97).

As we move farther into the narrator's memory of the Hemon family name, the evidence of its truth grows increasingly circumstantial. As readers, we are forced to question the reliability of our narrator. However, his inability to provide an accurate accounting of his family's narrative is not a function of selective narration; Hemon's narrator has no knowledge that he chooses to withhold. Instead, he moves the reader through the facts he has retained to be truthful in memory. There exists no historical base from which to narrate; he relays his acquired piecemeal information in montage-like form, none of which actually brings him (or us) to a "root." The form points to the inherently fragmented quality of he Hemon family history; there is no clearly situated geographic, cultural, or national origin to which the narrator has the ability to point, and as a result he struggles to accept the unknowability of his own past. These acts of remembering and telling function in many ways as witnessing in Felman's terms; it is not an objective truth that matters, but rather the narrator's act of telling and the reader's ability to engage in such a dialogic act that could promote healing. As Hemon's narrator continues, the significance of objective fact continues to fade in favor of subjective — and altered — memory. Yet the healing process doesn't end with these moments of testimonial witness. Rather, it requires the reader's involvement in a second and more salient way: the reader plays a key role in transforming this distinctly literary testimony into a form of historical record that makes clear 
its own inherent fractures and omissions, and provides an important bridge to international law.

Returning to Bruno, the narrator links his own history to an established literary root: he describes his ancestors, Alexandre and Marija, as "the Adam and Eve of the Hemon universe" (96). Hemon's history is one immersed in subjective memory, but he also seeks to imbue it with a literary past. Accordingly, Hemon points to the artificiality of the chronicle he has created. Just as characters in a novel can extend from historical truths or acts of imagination, Alexandre and Marija, too, are figures in an oft-told familial narrative, now transcribed into printed English.

The narrator's desire to establish a chronicle of his family illuminates the irrecoverable fractures within it. The story of Alexandre and Marija, it turns out, cannot be proven through fact as the political atmosphere of Eastern Europe thwarts that recovery — their records literally have been erased by communist purges. When the narrator's family tries to uncover the truth about Hemons in the Soviet Union, they are met with political resistance. Our narrator describes "a busload of excited Bosnian Ukrainians" who traveled to Lvov to seek out their roots:

In antique Ukrainian, just for the hell of it, they questioned toothless men leaning on their canes and fences about Hemons in the village, until one of them pointed peevishly at the house across the dirt road. The man in the house told them that yes, he was a Hemon, but he had no knowledge of any kin in Bosnia. He outright told them that he was no fool and that he knew they worked for the police (98).

The terror in the Soviet Union makes the creation of a legitimate historical record impossible.

While a judicial record could not proceed beyond this moment— there are no more objective facts to glean-Hemon's narrator can provide subjective evidence from memory to piece together the history of a family and a nation.

Judicial procedure is tasked primarily with a retributive function, and the ICTY has proven its ability to undertake this task. Yet the tribunal also alludes to elements of restorative justice, both in its written mandate and through its interest in historical recordkeeping. Such 
records, however, cannot pretend to be complete. Lacking subjective histories like those produced by individual testimony and recalled memory, legal records might be uniquely complemented with imaginative literature. Hemon's narrator retrieves a familial history outside the scope of international law, illuminating the restorative power of the novel. And when political elements slow the narrator's origin search, he reaches to literature to provide these roots. This turn imbues fiction, and the act of imagination, with an authority akin to a political act.

Indeed, the narrator brags that "[f]urther developments in the Hemon family-name history were propelled_-I'm proud to say_-by my literary exploits" (98). In phrasing his own reading practices as "exploits," the narrator situates himself as the adventurous hero in a detective story, working to excavate a familial lineage buried by historical collapses. In so doing, he creates a literary origin story for himself-as-character, one entrenched in the canonical epics of The Iliad, Antigone, and The Aeneid. In The Iliad, he uncovers "a lightning reference to 'Hemon the Mighty," while in Antigone he "discover[s] that Antigone's suicidal fiancé was named Hemon-Hemon pronounced as Haemon, just like our family name." Then, in " $[\mathrm{t}]$ he following semester," the narrator tells us that he "found a Hemon in The Aeneid, where he makes a fleeting appearance as a chief of a savage tribe" (100). Outside the vein of the historical epic, the narrator also inserts his relatives into the textual foundations of the Bible. He recalls his cousin Aleksandra's memory — a now doubly removed narrative — in which a priest described a man who stood in the murderous crowd under the cross on which Our Savior was expiring in incomprehensible pain, his eyes (the man's, of course) bulging with evil, bloodthirsty saliva running down his inhuman chin, laughing away Our Savior's suffering. 'What kind of man is he?' thundered the priest. 'What kind of man could laugh at the Lamb's slaughter? Hemon was his name, and we know that his seed was winnowed and scattered all over this doomed earth (100).

But assembling these literary works to establish a familial history betrays the inherently fractured quality of the past, begging for a form of objective truth that the law provides. 
In the montage of "Hemon" images throughout the canon, neither the narrator nor his father engages with the texts beyond a superficial level; the gatherings of the Hemon name, in an attempt to create a "whole," fail to investigate the intricacies of the literature and its relation (or lack thereof) to this Bosnian family. Indeed, the name itself retains a fragmented quality-a piece of a larger whole, the latter of which remains unacknowledged. The narrator explains that, in the process of the family-name assemblage, his father "didn't bother to read Antigone, never mind tens of thousands of lines of The Iliad" (99). The desire to know the origins of the name subordinates attention to the whole - the whole of each literary work, and the entirety of the montage of name references. Here, we might think back to legal recordkeeping and its emphasis on fact. As readers, it appears that there is no objective history for Hemon's narrator to recover - there is no possibility for any kind of such a historical record. Is there a whole history of the Hemon family available anywhere to reconstruct? It is as if the family's inability to define its national origins leaves it, and all subsequent generations, to remain in certain states of liminality.

This "Hemon archive," as the narrator names it, brings his family no closer to a recovery of their origins or to the materials needed to establish evidence of their cultural location. The report is by its very nature incomplete; it, too, dwells within the "nowhere spaces" to which emigrants are relegated. The kind of historical record compiled by the tribunal could never account for the history that Hemon's narrator seeks to piece together. Instead, we learn that there is another kind of history imbued with traumatic fracture, and it is our role as readers to collect those elements and place them together in the "Hemon archive" that we're ultimately tasked to create.

We do not just witness Hemon's testimonial narration, but our reading practice 
establishes a different form of record that extends the history of Yugoslavian violence beyond narratives chronicled in official records. To be sure, Hemon's readers become participants in an international human rights community as Slaughter imagines, yet we do so by broadening and deepening the original aims of the tribunal itself. Here, we might find ourselves returning to "Islands," piecing together the segments of Hemon's novel that together make up a tangible document of familial identity.

Given the reader's need to reconstruct the novel's sections in this way, Bruno contains startling implications for how our reading practices shape the imaginative capacities of literature and its bridge to legal praxis. Hemon sees to it that we become inherently involved in this process of recordkeeping by reading his book. Beyond the "Hemon" name search in "An Exchange of Pleasant Words," we are invited to add to the Hemon archive when a later segment of the novel leads us to encounter a "Hemon" who is seemingly unrelated to those in Bosnia and with another geopolitical positioning. In "Blind Jozef Pronek and Dead Souls," the protagonist emigrates from Bosnia during the early 1990s and relocates to Chicago, much like Hemon himself. Looking for employment, Pronek takes a kitchen-help job at the downtown Boudin French Sourdough Bakery. In his "food-service career," Pronek becomes "an apprentice to a man named Hemon." We soon learn that “Pronek didn't know whether Hemon was the man's first or the man's last name," but that "he was from the Dominican Republic" (181). An emigrant himself, the Dominican Hemon "spoke no English," and would "sit in bilingual silence" with Pronek during lunch breaks at the bakery (182-83).

In this scene, the text points to the limitations of linguistic translation but proposes the possibility of another kind of knowledge — a form of history-making undertaken by the reader (183). "Hemons" in other stories within 타no can illuminate the lost saga of a family name, 
and it is a new one rooted in global movement. As readers, we must pull the Dominican Hemon into the archive, adding to the familial history. More significantly, the text urges its reader to maintain the Hemon archive even beyond the bounds of the novel. We become implicated in the creation of this fragmentary collection as we piece together the Hemons in "An Exchange of Pleasant Words," and then we add to the record as we locate additional Hemons from another hemisphere in "Blind Jozef Pronek." If we were to encounter an addition to the Hemon archive in another text altogether, Hemon (as the author) might hope that we use it to reconstruct his family's historical record even further. As curators of the family's name, we are also repairers of the Hemon history. Given the potential for this restorative function to take place at any moment of reading, the novel also allows the aims of the ICTY to extend beyond its temporal boundaries. In short, the creation of subjective histories of the Balkans through fictional readings can continue even after the ICTY fulfills its timed mandate. In this way, restorative justice remains an ongoing process in which imaginative literature plays a central role.

It's important to keep in mind that the novel does allude to the limitations of the reader's ability to stand against the evacuations of human history. Much as the tribunal system retains lacunas, so does imaginative literature. Certainly, the collection of "Hemons" grows in quantity through reader participation, thereby producing a limited historical and geospatial knowledge about the family's existence. At the same time, a series of omissions that illuminate ruptures in knowledge and memory mark the distributed quality of the Hemon family account. In this way, Bruno illustrates a geographic and spatial translation that is marred indelibly by emigration. In the novel, narrative erasures speak to the transmutation of persons and the losses that arise in palimpsestic histories. For Hemon, these deletions begin in the early interwar years, which saw the establishment of the Kingdom of Yugoslavia alongside mounting ethnic tensions among the 
Muslim, Croatian, and Serbian populations. The narrator describes his Uncle Ilyko's tumultuous journey across the Romanian-Yugoslav border in 1922, during which he "swam across the Danube, whose murky, cold waters dissolved the daguerreotype" (103). The first evidences of transnational erasures also implicate the fault of the geographic space and its contrived borders. It is the crossing between Romania and the Kingdom of Yugoslavia, once shared national land within the recently dissolved Austro-Hungarian empire, that eradicates this image.

In the partial destruction of home-movie footage from the "Hemoniad" family reunion, this fracturing becomes tied to the Hemon family's forced migration from Bosnia to the United States. While the story form demands that the teller select some, but far from all, of the available facts, the film that the family carries from Bosnia to America no longer has all of the "facts" from which to construct a story. "On the videotape of the Hemoniad," which the narrator describes as "the only document of the glorious festivity that reached the United States," moments of the event are erased in the technological translation process necessary to view European film on American video equipment (107). For after describing the scenes documented on VHS, the narrator saliently remarks that "[it] is important to note ... that the flies disappeared in the process of converting the tape from PAL-SECAM to NTSC" (108). The buzzing insects of a lively picnic are lost. The narrator not only marks the inherent losses of a physical translation process, but he also points to the ruptured wholeness of the family's story and memory. ${ }^{172}$

In this moment, Hemon's work to redefine translation comes to the fore. While Hemon

\footnotetext{
${ }^{172}$ Arthur C. Danto explains that when an informant tells a narrative at trial, he would be dismayed if, rather than talking about the substance of the story, the informant described a fly that was circling in the courtroom, unless, of course, the informant were to use the fly as the dramatic flourish to the story. The example illustrates a familiar point: the story form always demands selection from all of the available facts, yet it also points to the losses inherent when a storyteller no longer has evidence from which to pull even the "flourishes." Arthur C. Danto, Narration and Knowledge (New York, Columbia UP, 1985), 131.
} 
himself has suggested that some immigrants find "transformation" to be "as depletion —as death," his novel implies a restorative function inherent in geographic and ethnographic shifts. ${ }^{173}$ In "Task of the Translator," Walter Benjamin contends that translation actually is a reconciliation of parts. Speaking of texts written in one language and transformed into another, he describes both the original and its translation as entities that are "recognizable as fragments," and goes on to explain that, in the process of translation, a kind of "reconciliation" occurs between the two. ${ }^{174}$ While Benjamin's essay traditionally has been considered in relation to linguistic translation alone, his theoretical work presents exciting possibilities for the literary reclamation of lives disjointed through the trauma of mass violence. In his final book, The Arcades Project, Benjamin emphasizes that processes of re-assembly can lead to new forms. ${ }^{175}$ These assemblages might provide an "afterlife" for the collection of pieces, re-imagining them as a newly unified whole. ${ }^{176}$ Hemon conceives this "whole" not as one pieced back together again, but as something made anew. In so doing, he illumines the significance of the reader in essential processes of collecting and assembling a literary record of exilic identity.

Questions of the fragmentary and the reader's role in envisaging elements of human recovery are further tested by the epistolary form in "A Coin," which grapples with the limitations of storytelling and recordkeeping in the midst of ongoing violence in Sarajevo. Given that the siege threatened the possibility for corporeal recovery and destroyed the spatial history of the city, how might literature reimagine the knowledge acquired through dialogue and recordkeeping? And how might the novel address the ongoing and multilayered qualities of

\footnotetext{
${ }^{173}$ Knight, "Conversation," 97.

${ }^{174}$ Benjamin, "Task," 78, 75.

${ }^{175}$ Walter Benjamin, The Arcades Project (Cambridge, Belknap, 1999), 431.

${ }^{176}$ Benjamin imagines an "afterlife" for works in translation, explaining how "the history of the great works of art tells us about their antecedents, their realization in the age of the artist, their potentially eternal afterlife in succeeding generations .... For in [the] afterlife - which could not be called that if it were not a transformation and a renewal of something living — the original undergoes a change." Benjamin, "Task," 71, 73.
} 
traumas inflicted by war?

\section{Epistolary Fragmentation and the Nowhere Space of Besieged Sarajevo}

The distributed characteristic of humanity might best be imagined through "A Coin," the only story in Bruno that directly engages the recent chronicle of the war in Bosnia. Made up of an exchange of letters between a Bosnian refugee in America and a film editor trapped in Sarajevo between 1992-1995, the story's form draws immediate attention to its fractured quality. The letters consist of descriptions of everyday life in Sarajevo and the experience of news reporting in the besieged city. Between letters, Hemon's narrator offers commentary. Yet for the first time in Bruno, there is no distinct narration to guide the reader through the text. Instead, the story consists primarily of a series of letters written by Aida, the Bosnian film editor, to which we presumably are asked to respond ourselves.

Yet this narrative cleft gives way to a plot entrance in media res; the reader begins with one of Aida's letters in narrative midstream. We are not granted access to the communications that have come in this epistolary dialogue prior, and the letter with which we begin has itself already begun; there are no dates or greetings. In fact, the content of this first letter not only marks a formal rupturing of the text, but it also references the immediate and fractured geographic space of the streets of Sarajevo. Sniper fire literally split the city, with the Yugoslav army on one side of the Miljacka River and the Republika Srpska army on the other. "A Coin" overlays rupture upon rupture, creating an image of the multifaceted nature of trauma, but also of the oscillating spatial and metaphysical fissures in this history. The epistolary story breaches the singular narration of Bruno by introducing the polyphony of character and reader alike, while the form of the letter visually splinters the pages of the text, linking it back to "Islands." While the 
time period of the story is markedly distinct from "Islands," Hemon tells us that the two stories - of Tito's Yugoslavia and of Sarajevo under siege - are very much part of the same historical narrative.

Aida's letters betray a striking language of binary that introduces us to the narrative gap — to which we originally were introduced in "Islands" - that has developed to tell a story about life in Sarajevo in the early 1990s: "Suppose there is a Point A and a Point B and that, if you want to get from point A to point B, you have to pass through an open space clearly visible to a skillful sniper. You have to run from Point A to Point B and the faster you run, the more likely you are to reach Point B alive. The space between Point A and Point B is littered with things that sprinting citizens dropped along the way" (119). This image of geographic break is enmeshed with descriptions of the disjointed objects on the ground, which themselves cannot be described in complete sentences. Here, the grammatical narration mirrors the quality and state of these entities:

A black leather wallet, probably empty. A purse, agape like a mouth. A white plastic water vessel, with a bullet hole in its center. A green-red-brown shawl ornamented with snowflakes, dirty. A wet loaf of bread, with busy ants crawling all over it, as if building a pyramid. A videocassette, dismembered, several of its pieces still connected with a dark writhing tape. On days when snipers are particularly rabid, there are scattered bodies as well (119).

The objects in the list themselves are scattered, yet the final "item"- - bodies_-comes in a complete sentence. Here, Aida's letter tells us that, even when descriptions take the form of completeness, such as the "bodies" here, their substance still can be irrevocably marred by violence. The list saves the most gruesome of the scattered entities for the complete sentence that closes out the dispersed image of the objects.

While the deep fragmentary nature of these letters is introduced at the beginning of the story, its epistolary nature also offers a possibility for dialogue that expands upon its perceived 
narrative limitations. Despite its formal fractures, the letters create the possibility for a testimonial encounter between Aida and the reader. This dialogism takes a form of witnessing that might best be reimagined through the theoretical modeling of Mikhail Bakhtin. While Felman and Laub acknowledge the incomplete nature of traumatic memory and emphasize the restorative experiential capacities of remembering and telling, Bakhtin's writings suggest an important expansion upon these principles that can take into account the significance of the historical and geopolitical qualities of suffering. In The Dialogic Imagination, Bakhtin echoes Benjamin as he ameliorates the feature of fragmentation, suggesting its power to enhance dialogues and to produce knowledge about the interrelations among literature, time, space, and history. The idea of "pretending to completeness," as certain trauma studies ideas tends to, proves somewhat alien to Bakhtinian ideas of dialogism. Unlike a trauma studies model that assumes the existence of a once-complete person who has been damaged by violence, and a wound that can be clearly demarcated in time and space, Bakhtin instead works from the idea of the constantly shifting natures of being. As such, he thwarts the notion of a trajectory of a harmful event that breaches wholeness and must be repaired. Instead, his work suggests a consistent and constant need for dialogue among disparate entities, or a constant interplay among pieces of discourse, no matter their temporal location, that might create new ideas or notions of "wholeness" through interaction and exchange. Given his focus on the ameliorative quality of fragmentation, he identifies a useful conception of fluid personhood, marked by fissures and injuries, that speaks to the polyphonic qualities of literature across time and space. Accordingly, Bakhtin connects these divisions of personhood to the novel, explaining that entities "can never have whole and final definitions, as utility and dialogue of the novel can always shift by its nature" (84). His work points especially to literature occurring in the realm of "everyday time," 
in which "fragmentariness" is remarkably salient (128). Can dialogue initiated by a fractured being, such as Aida, ultimately produce a new kind of narrative wholeness? It is this very form of dialogue, Bakhtin suggests, that actually propels narrative forward between character and reader, and is at the roots of creative imagination.

By engaging in a dialogic encounter with Aida's letters, we might produce a literary recovery of narrative. Yet while Bakhtin offers a model for restoration that involves dialogue between disparate pieces, formal elements in "A Coin" at first deny this impulse toward dialogue. To begin with, the story is bookended with letters from Aida, yet the reader never gains real access to her conversations with Hemon's narrator; we are only provided with Aida's letters and the narrator's infrequent commentary. In fact, the narrator at one point implies that he lacks the language through which to engage in written response to the letters: "I think of all the things I could've told her or should've told her: how awkward and cumbersome I feel in English, sinking in syntax, my sentences flapping helplessly like a drowning child's arms" (124). As with the style of storytelling throughout Bruno, Hemon's narrator finds himself in a "nowhere space" in which he questions his personal relationship to nation and language. With whom do we identify here as readers? With Aida or the narrator? To be sure, "A Coin" makes the reader's entrance to the story difficult. However, we learn that the dialogic frustrations in the story are not for want of trying; the time and space of the letters themselves thwarts dialogism and its inventive possibilities. Hemon suggests that it is the violence that has marred Bosnia that initially inhibits discourse. Here, he depicts how the very real location of Sarajevo is turned "static" through the lack of communication outside its space; it "has no becoming," as Bakhtin suggests is necessary for a dialogic encounter (128). 
As Bakhtin understands the "chronotope" in literature, ${ }^{177}$ Hemon's story reveals that a narrative centered around epistolary communication during the siege of Sarajevo in fact has no chronotope - it produces no concrete image of time and space. The destruction of the city, and the threatened obliteration of the letters and dialogue that come from within it, display a history halted both temporally and spatially. As such, the very idea of dialogic encounter between witness and testimony is also called into question; without a discernable chronotope, the reader finds only an "alien world" in which no markers of time and space exist, and accordingly, no moment endures in which the "world [can] bear witness to the distinguishing features of a particular era," or in the case of Sarajevo, a city and its culture (Bakhtin 129). ${ }^{178}$

This feature of "A Coin" also draws attention to historical recordkeeping limitations, suggesting the importance of such an act—Aida's letters could in fact create testimonial account of the siege — but its literal impossibility. Given its stagnancy, the city can have no place in a chronological historiography of fact. Rather, dialogic encounters initiated within such a space point us toward the very objective limitations of any act of historical recordkeeping; such an endeavor assumes the location of geopolitical crises definitively in time and space. Since we do not have that luxury, "A Coin" asks us to reconceive the process and scope of documenting a past. In order to fully understand how this plays out in Hemon's writing, it is useful to more closely consider the interplay between Bakhtinian theory and Hemon's conception of war-torn Sarajevo.

Hemon ultimately proves that dialogic possibilities exist in literary encounters that are

\footnotetext{
${ }^{177}$ Bakhtin defines the chronotope as an entity in which time and space converge, an entity that "expresses the inseparability of time and space" (84). He explains that a novel's "relationship to an actual reality is defined by its chronotope," and that "chronotopes are the organizing centers for the fundmanetal narrative events of the novel" $(243,250)$. They are "the meaning that shapes narrative," and the entity through which "time becomes, in effect, palpable and visible" (250).

${ }_{178}$ Bakhtin at times refers to the "alien world" of the adventure novel, but I use "alien world" here, as Bakhtin describes it, as one in which no chronotope is easily discernable. It is not the identifiable "alien world" of adventure time or of another distinct genre, but of an "alien world" that has no markers of genre or geopolitical positioning.
} 
marked by the eradication of time-space boundaries, but he does so first by identifying his narrative as one chronotopically void. Aida's first letter introduces the reader to a Bakhtinian "alien world" in which "everything in it is unknown, foreign," as she describes the scattered quality of the city and its fragmentary contents, as I discussed previously. We are further alienated from Sarajevo as Aida describes the city's dog and cat population. "Sarajevo is a catless city," she writes, explaining that, because the siege prevented pet owners from taking dogs and cats into underground shelters or fleeing with them in tow, the abandoned dogs "hunt down" and "devour" the cats out of necessity (119). Aida prosaically explains that "one can often see, among the rubble on the streets, underneath burnt cars, or stuck in sewers, cat carcasses, or cats heads," and that "sometimes one can see two or more dogs fighting over a cat, tearing apart a screaming loaf of fur and flesh" (120). Despite Sarajevo's prominence in political and literary history-Hemon reminds us earlier in Bruno that it was once the notorious site of the assassination that ignited World War I and later the cosmopolitan city remembered for the 1984 Winter Olympics - the narrative here turns the city into an alien space without a history. Certain Sarajevo signifiers have been destroyed, yielding none of the knowledge necessary for everyday life. ${ }^{179}$ The already horrific dynamic among abandoned pets is deepened as the text likens the animals to readily purchased food: "loaf[s] of fur and flesh" (120).

This unfamiliarity is heightened in Aida's likewise banal description of her aunt's death, which becomes a microcosm for the alienation of Sarajevo and its position in a liminal time and space - one of the "nowhere spaces" to which Hemon refers throughout Bruno. In discussing the death and decay of her aunt, Aida depicts an experience outside the psychological bounds of conception:

In September, Aunt Fatima passed away. She had had asthma for a long time, but in

\footnotetext{
${ }^{179}$ See Michel De Certeau for an exploration of city space and everyday encounter.
} 
September she just asphyxiated in our apartment. They were pouring shells for weeks on end, and even when they didn't there was an eager sniper . . . . We couldn't bury her, or even take her out, because they kept shelling and sniping as if there was no tomorrow ... .We kept hoping that we would be able to bury her, but a week passed and she was still there - my malodorous aunt .... The odor escaped Fatima's room no matter what we tried to do. We stuffed the cracks between the door and the frame with rugs. We soaked the rugs and the door with vinegar or useless perfume (Obsession, Magie Noir). But the stench was always there - the sweet, dense, meaty scent of decay. In the midst of a rare and brief nocturnal lull in shelling, we decided to throw her out the window" (127).

Aida's letter situates the city in a space without time. She dates the incident she narrates in "September," yet this temporal and spatial positioning has lost meaning in both her epistolary discourse and in Sarajevo; it no longer matters where it is September or another month, for the residents of the city see no end to the violence that has encapsulated it. Aida's reference to the snipers shelling "as if there were no tomorrow" reminds us that we are reading the history of a moment in which there may not be a tomorrow; the reader is thrust into a city space in which the terms "everyday," "day-to-day," and "tomorrow" have lost all meaning and provide no assumption of chronology. Any historiography of the siege must be narrated outside a traditional form of chronological recordkeeping.

In addition to the "nowhere space" that Aida occupies, Hemon suggests that the nation of Bosnia too has become a "nowhere space," existing outside the traditional signifiers for time and place. Accordingly, these "un-markers" of temporality are replaced by the false "time" created by the violence of shelling and sniper fire. Temporal references to the city no longer signify a timeline of events. Rather, the history of the city can instead only be reported through a collection of letters like Aida's, unmarked by specific dates, moments, or sites. In some ways, we might imagine this collection as connoting a "violence-time" in a Bakhtinian universe."180 But instead, lacking temporal and spatial markers deny its very linguistic definition.

\footnotetext{
${ }^{180}$ For an explanation of the alien worlds of "adventure-time" and "romance-time," and how Bakhtin ascribes such time codes to certain novels, see The Dialogic Imagination.
} 
The impossibility for temporal-historical markers reflects upon the likewise untenable process of identifying besieged areas by sight; their visual signifiers have been erased. The narrator recounts how a friend asked him "to help her identify some buildings in Sarajevo" that had been shelled (128).

She sent me photographs hoping that I could recognize the buildings," he explains, "but they were unidentifiable as far as I was concerned. They all looked the same: they all had shattered windows - black holes, as if their eyes had been gouged; there were rings of debris around them, as if ruins were being carved out of whole buildings .... What was in the pictures were not buildings-let alone the buildings I could've come in or out of (128).

Not only does the narrator find it impossible to identify the buildings he sees, but in fact exclaims that the images he sees no longer are city buildings at all; the signifier of an apartment building or library, for instance, have no meaning in besieged Sarajevo. Hemon's descriptions of Sarajevo here pejoratively reimagine a novelistic space in which there is "no indication of historical time, no identifying traces of the era," as Bakhtin might describe (91). While this quality can place certain genres in a distinct dialogic position with other genres, the "empty time" here "leaves no traces anywhere, no indication of its passing" (91). As such, Hemon presents us with a space that cannot move forward in dialogue with any other; the movements of dialogism appear stifled. The world in Hemon's text ultimately proves itself to be on the verge of complete destruction and utter disappearance, denied the possibilities for restoration and reconciliation. For our narrator explains that, not only are the buildings of Sarajevo unrecognizable in time and space, but they are also "pictures [that] recorded the very end of the process of disappearing, the nothingness itself" (128).

Yet the epistolary form of the narrative ultimately restores this dialogism; it thrusts the temporally vacant space of Aida's besieged Sarajevo into a dialogic form capable of restoring human signifiers and spatial demarcations into this otherwise "nowhere" place. Through the 
substance of the letters, which by their very existence imply dialogic encounter (someone writes the letters and we read them), Hemon makes clear that Sarajevo has become a world alien to the markers of everyday life, time, and space. To be sure, the content of the letters displays the dialogic limitations of a text defined by omitted temporal or spatial classifications; Hemon identifies the violence inflicted upon Sarajevo as one that is at once static, with fractures that cannot move toward closure. As such, the substance of Aida's letters suggests that the wounds of the city and its inhabitants remain temporally trapped. However, by using the epistolary form to halt recovery, or to prevent Sarajevo from "becoming," Hemon establishes the basis for a new kind of restorative dialogism and the witnessing of trauma. If there is no literary chronotope at all, and if dialogism is denied by the stagnant quality of the space of narrative, Hemon invents instead an imagined dialogue among his readers, his narrator, and Aida to recreate a new possibility for human recovery. He reimagines the quality of the chronotope through the representation of traumatic witness.

The letters show a different kind of restorative process within a Sarajevo that at first appears to deny the very existence of time and space, as it is at once temporally fixed between 1992-1995. And the political violence affecting the city thrusts it into an inert space that cannot be marked by traditional signifiers of time, as I have discussed previously. Early in her letters, Aida describes constant news footage of the siege and explains her process of collecting its destruction, a process that ultimately lends itself to recovery rather than disintegration: I get twothree hours of footage everyday. It's mainly blood and gore and severed limbs. I cut it into fifteen-twenty minutes, which are then transmitted to the invisible people who edit it into onetwo minutes of news story" (122).

At first, Aida implicates herself in the process of fragmentation by documenting it in a 
fractured manner-her videotapes never include whole pieces of narrative, and we can assume that a majority of her films simply are discarded. Yet after being shocked by the image of a dead and disfigured victim — a human reaction that seems otherwise impossible from within the city space-Aida turns instead to the process of (re)collecting. She continues to cut segments of horror, but "from then on," she writes, "I put it all on one tape, which I hoarded underneath my pillow made of clothes" (123). When fact is made to look like fiction or unreality, the re-piecing of Aida's disaster-film segments from news footage, housed underneath a pillow that also represents an impulse to "put back together," create a post-traumatic "whole" of Sarajevo. From here, she imagines an "after trauma" state, moving Sarajevo from static positioning into a city in which a future might exist — a videotape that moves, regardless of its chronology, through time and space.

As we read about Aida's process of collecting film snippets, we are invited to mirror this practice that Hemon first established for us in "An Exchange of Pleasant Words." Hemon encourages his reader to collect Aida's letters in our memory— to put them in a chronological order inasmuch as possible to restore a history of the siege and individual personhood within it. We are thwarted by the narrator's interior commentary concerning events that Aida witnesses and describes in her letters, yet we are nonetheless urged to mimic the narrator's impulse to in turn bear witness to Aida's pain and to collect her letters into a different kind of "whole"; wholeness becomes a relative term depending on individual identity, political circumstance, and geographic-historic location. The reader is asked to perform a task that seeks to reconceptualize unity within the punctual moment of the siege, while acknowledging the impossibility of such a wholeness due to the apunctual nature of the trauma that continues throughout and after the war. Given the limitations for a traditional theory of "making whole" through Aida's letters, 
Hemon's story invents a new literary form of witness. In "A Coin," we observe and then actively collect fragments of victimhood into a newly conceptualized document of the past, but we are left with an inherently severed entity that reflects upon the Hemon family history produced in "An Exchange of Pleasant Words." Here, I use the term always-already in the Hemonian sense to identify the condition of being (and becoming) in a nation that has become a "nowhere space." The different kind of completeness produced in "A Coin" speaks irrevocably to wounds sustained and to the fissures inherent in "being put back together," but distinctly not to being "put back together again." Unlike the legal and philosophical presumptions concerning the fractured wholeness of a victim through injury, Aida's letters create a narrative in which there is no original whole from which a reader can work. Like Hemon's narrator in "An Exchange of Pleasant Words," we cannot conceive of what an original might look like, yet at the same time this does not suggest a limitation to our imaginative response. Rather, bearing witness through collecting becomes an imaginative process through which discourse between reader and text sparks the power of new creation. In this way, "A Coin" helps to reformulate conceptions of human evacuation through an ameliorative notion of fragmentariness, even in the face of violence. In so doing, it invents a new mode of documentation in which traditional signifiers of "history" and "record" acknowledge the limitations inherent in traumatic narration, thereby establishing a new model for literature's engagement with the law.

The very nature of suffering and the possibilities for reconciliation discussed here become clearer through an examination of humor in Hemon's writing. Considering the stark limitations of storytelling, dialogism, and historical recordkeeping in the Court of $\mathrm{BiH}$ alongside Hemon's "The Life and Work of Alphonse Kauders," the author questions the basis of telling a historical narrative through his play with language. How can we come to terms with the siege of 
Sarajevo nearly twenty years later? And is it possible to produce new models of narrative reclamation for events, such as the Yugoslav wars, that have now become a part of social and legal history? While his writing bears upon the gravity of such an issue, Hemon's diction betrays a tone of playful seriousness through which he makes his readers laugh, thereby creating a recuperative form of the historical narrative.

\section{Serious Play and Playful Seriousness: Humor in the Literature and Irony in the Courtroom}

While Hemon asks his reader to perform the act of collecting and bearing witness in "An Exchange of Pleasant Words" and "A Coin," he shows us the power of distance in "The Life and Work of Alphonse Kauders." Speaking to the drama inherent in certain witness examination models in the courts of Bosnia and Herzegovina (BiH) — what I call here "serious play"-Hemon resorts to playful seriousness, looking to humor as an antidote for political and legal traumas. Novelist Nadine Gordimer described the use of irony as a tool to demarcate political underpinnings in a text that offers its commentary on the state of a nation's human flourishing. In this kind of novel, she explains, the political theme must become "dictated by the conviction, if-we-don't-laugh-we-shall-weep at what we see" (Gordimer, “African Writing"). So, too, Slavoj Zizek seeks to employ laughter — the joke, specifically—as a literary and philosophical tool for comprehending the intertwined aspects of politics and being that distinctly arise from the Balkans. ${ }^{181}$ In this segment of Hemon's novel, his use of irony remarks on those political conditions that become grotesque and uncanny. The style reveals his deep concern with identity and belonging in the wake of injury to one's home country. Given this pursuit, Hemon poses the question: can laughter be recuperative?

Humor has long been considered a mode of combating oppression, or as a way to make

\footnotetext{
${ }^{181}$ See, for example, Zizek.
} 
evil manageable. ${ }^{182}$ If we can laugh at it, evil becomes comprehensible. Such an idea appears frequently in postwar narratives, and we need only look to Hannah Arendt's depiction of Eichmann as a clown or to Ernst Lubitsch's To Be or Not to Be to see how aesthetic representations of Nazi totalitarianism become manageable through laughter. If Eichmann is a clown, or if Nazi S.S. officers become part of Shakespearean comedy, then tyranny becomes something knowable. ${ }^{183}$ As Terry Eagleton has noted, "joking with the rope around your neck is a feeble way of transcending your oppressor, but it is a sort of transcendence all the same, which someone else may find a use for." ${ }^{184}$ Indeed, other thinkers have identified humor as a tool that can be useful to work through historical tyranny and its lingering wounds. J.E. Elliott argues that humor gives writers "a special license to play with the past, recasting the symptoms of rejection or paralysis to thrust the implicit charge of shameful negligence before an impious public."185 Elliott emphasizes the utility of literary humor, recalling Mary Douglas's sociological claim that humor as function takes precedence over its aesthetic properties (1063).

Humor has a recuperative function, allowing authors like Hemon to redefine our relationship to past harms that continue to haunt us in the present. For Hemon, the wounds of Nazi and Soviet totalitarianism loom large in the national Yugoslavian narrative. Recasting that history in a style of playful seriousness produces a knowability of that evil, such that we might readily combat it. The laughter produced in Hemon's work "takes shape as the reflex of recuperation, its practice of allotting names to the nameless, a progressive domestication of the Other" (Elliott 1056). The Other is reimagined in Hemon's writing as an unknowable threat that

\footnotetext{
${ }^{182}$ See, for example, Deleuze's discussion of comic boundaries Difference and Repetition; Foucault's discussion of the philosophical laugh in The Order of Things. See also imaginative works in which humor and political violence are linked, such as Charlie Chaplin's film The Dictator, or Spike Jones' song, "Der Fueher's Face."

${ }^{183}$ For a discussion of Ernst Lubitsch and the blending of humor and tyranny, see Eyman.

${ }^{184}$ Eagleton, Walter Benjamin, 61.

${ }^{185}$ Elliott, 1060.
} 
can be made intelligible through narrative play. And indeed, by eliciting laughter, Hemon alerts us that we are no longer in the realm of the tyranny he narrates. Marc Silberman, writing of Brecht's comic drama, explains that "only the social formations that have been transcended or 'overcome' can be laughed at; that is, once they are no longer threatening"' (Silberman 177).

Can any laughter heal? The style of humor connected to recovery from political violence stands in stark opposition to that produced in the courtroom spaces of Bosnia and Herzegovina. The playful seriousness in Bruno occupies a role distinct to contemporary global narrative. In the Bosnian courtroom, nervous laughter abounds, and it is markedly different from the humor connected with literary recuperation. Social psychologists identify nervous laughter, starkly different from the form that Hemon elicits, as that produced in situations of fear and discomfort where laughter becomes an involuntary physiological response. ${ }^{186}$ The adage that we laugh so that we do not cry shows itself to be very different from the stylistic acts that Hemon performs.

Looking at the rules of court for crimes against humanity offenses can help to distinguish the function of Hemon's literary play from other forms of humor. Per Rule 11 bis of the ICTY Rules and Procedures, cases from the ICTY are transferred to the Court of BiH for local prosecution in order to relieve the docket in the Hague. Yet in the Court of $\mathrm{BiH}$, a system of legal rules has metamorphosed into one that produces nervous laughter. As such, the rules for the local Bosnian court's war crimes prosecutions provide an interesting framework through which to engage connections among humor, voice, and restoration. For example, Articles 85 and 259 of the Criminal Procedure Code of the Court of BiH specify the method of examination and confrontation of a witness. Article 85 indicates that a defendant may confront a victim himself,

\footnotetext{
${ }^{186}$ For a discussion of nervous laughter and its relationship to fear and discomfort, see Keltner and Bonanno.
} 
offering an unusual account of "truth" in response to that provided by a testifying witness. ${ }^{187}$ In other words, the defendant may offer his own testimony in response to the victim-witness, creating a distorted dialogism. Article 259 then specifies that, during a witness examination, "the accused may present facts and propose evidence in his favor," and that he may "offer explanations regarding the testimony" of those witnesses. These rules sidesteps traditional notions of how a courtroom encounter should play out, wherein the witness should never be forced to directly confront a perpetrator (or to be confronted). Since defendants are free to confront witnesses willy nilly with their own subjective interpretations of testimony, witnesses experience the re-opening of traumatic wounds to which they are testifying. Article 85 denies witnesses the protections inherent in international law by which a defendant's contact with victims is limited, while Article 259 allows for competing testimonies in which only one will win out. At the local court level, they can be re-traumatized-leading either to a pejoratively dialogic battle between defendant and witness, or to a one-way encounter in which the defendant silences the witness. Such images of a witness examination illuminate the original and ongoing traumas in the Balkans to which Hemon's fiction refers.

Given that these courtroom scenes are highly performative, they stage a serious play in which nervous humor lurks in the absurdity of the scene. An ICTY prosecutor, visiting one of the $\mathrm{BiH}$ courts prior to a case handover, described a defendant's interrogation of a victim-witness as a "circus show," 188 not unlike Arendt's description of Eichmann's trial. However, this court rule does not invite the recuperative amusement within Arendt's Eichmann depiction, or of Hemon's playful historical narrative. To be sure, we are not invited to laugh, but do so because we do not know another response. The grotesque quality of the encounter between defendant

\footnotetext{
${ }^{187}$ Section v, Art 85(2): "At all times during the proceedings, witnesses may be confronted with other witnesses or with the suspect or accused."

${ }^{188}$ Interview with Najwa Nabti, July 13, 2012.
} 
and witness becomes one of terror in which multiple voices and perspectives converge, denying any "truth" for posterity or legal remedy. The courtroom becomes a site in which possibilities for restoration are traded for new injuries enacted by the rules of trial. For ultimately serious matter, the court transforms into a space of false play and psychological injury. Hemon's humor offers a function alternative to that of the Sarajevo courtroom.

Engaged deeply with questions concerning the singularity of historical knowledge and the potentially restorative notion of revisionist history, "The Life and Work of Alphonse Kauders" uses the encyclopedic form to provide alinear anecdotes and information about a fictional Serbian official named Alphonse Kauders. Each pithy entry begins either with Kauders' name or focuses on his role in a chronological moment between Stalinism and the aftermath of WWII. Interspersing information about Kauders with remarks concerning real figures (e.g., Stalin, Hitler), the text plays with a narrated past and the healing quality of the political joke. By reconstructing history through humor, Hemon ultimately seeks to "preempt the willful misuse of history" (Elliott 1059). His playful seriousness functions first to identify a traumatic history as comprehensible and thus manageable. By creating a narrative that invokes laughter, Hemon informs us that we reside in a position of safety relative to that violent past; we can laugh because we are apart from it. But most importantly, Hemon alerts us that his humor can also be a political weapon to use against tyranny. In a space of temporal distance from the events Hemon reinscribes, he show us that the very worst offenses against humanity can be made intelligible through stylistic play. From our position of comfort, Hemon informs us that the comprehensibility of evil means that we can act against it, and must, if we encounter it again. Like Brecht, who "saw the transgressive power of humor as a weapon," Hemon uses it "to convey a serious message about the need to intervene and change the world" (Silberman 170). 
And by linking historical atrocities to the ongoing traumas in the Balkans, Hemon suggests that literary humor can in fact set forth a new road of recovery.

How can humor define the model by which restoration might occur when pejorative models of serious play limit the ability for the BiH courtrooms to carry out justice? Hemon's "Alphonse Kauders" creates a space of play and humor amidst the seriousness of historical injury and atrocity. Provided that this "margin of safety," or the gaps created by literary fragments, successfully creates an area in which laughter becomes the appropriate response to suffering, Hemon reimagines how we deal with historical trauma. ${ }^{189}$ Can humor repair what ails us? Hemon relies deeply upon our assumed knowledge of the historical figures immersed in the text and our objective knee-jerk responses to their names, and he seeks instead to produce, through humor, a new historical knowledge that counteracts the political violence associated with totalitarianism. The narrator, like Hemon's others, is a vociferous collector of historical facts. Yet in "Kauders," the act of collecting has revised stakes, and as I will show, there is a restorative payoff in laughing. It is not that we must laugh, as Gordimer and Zizek might suggest, but the act of realizing we can laugh. The potential for human recovery lies in our ability to be amused by what we read, thereby marking as knowable the political violence that we are ready to combat. Through humor, we begin to render impotent the mythic power of totalitarian oppression. In order to create such a relationship between reader and text, Hemon first must establish the "margin of safety" that permits us to laugh.

Situating the character of Kauders temporally in the midst of Communist politics, Hemon first demarcates a historical distance from the reader - Kauders is a time and figure from the

\footnotetext{
${ }^{189}$ Identifying a "margin or safety" produced by humor is introduced by Brecht at mid-century, who depicted humor as " a feeling of distance." Marc Silberman emphasizes the spaces, or margins, created by recuperative humor: "Because the comic depends on the incongruous, the paradoxical, and the absurd in behavior and situations, it generates that distance so crucial to ... opening up a space for historical cognition while rendering visible the contradiction in society that make the status quo impossible" (185).
} 
past. Yet, Hemon creates a margin of safety for us with an initial reflexive move; we are already reading a work of fiction, but he forces the reader to question the fictionality of the text at the start of the story. Given the title's biographical implications, we expect to find information about Kauders, and Hemon provides it:

Alphonse Kauders is the creator of The Forestry Bibliography, 1900-1948, published by the Engineers and Technicians Association, Zagreb, 1949. This is a special bibliography related to forestry. The material is classified into seventy-three groups and encompasses 8,800 articles and theses. Bibliographical units are not numbered. The creator of The Forestry Bibliography was the first to catalogue the entire forest matter in a single piece of work. The work has been viewed as influential (25).

Kauders is situated for the reader in a series of fact-driven descriptions that have been collected into this book - temporally in the first half of the twentieth century, geographically in Zagreb, substantively in the science of forestry, ${ }^{190}$ and statistically in its scientific specificity of the material's classification. The un-numbered bibliographic entries separate Kauders' life and work from the markedly numbered fiction of "Islands." If the text were serious, this is what it could be about: Kauders' life and work in the science of forestry and bibliographic collecting. In fact, the potential absurdity of "catalogu[ing] the entire forest" into a single book made of forest materials is disregarded in favor of the objective truths that the text feigns to present.

However, Hemon then creates dissonance for the reader, shifting away from Kauders' supposed professional affiliation and into a "fact" that stands in opposition to the significance of an "influential" scientific book. The text is not actually serious - both thematically and formally, Hemon moves away from the bibliographic entry. In this shift, "Alphonse Kauders," we learn, "had a dog by the name of Rex, whose whelp, in the course of time, he gave to Josip B. Tito" (25). Here, Hemon creates a preliminary space for humor. The humor is of a different variety than that of the grotesque or the absurd that we see at work in the war crimes courtrooms of

\footnotetext{
${ }^{190}$ Of course, "forestry" can also refer to the applied art of forestry, reflexively implicating the fictionality of literature in this once-wholly-scientific field.
} 
Bosnia and Herzegovina, and resembles instead the form of humor produced by Brecht, as Silberman defines it; Hemon's play turns the seriousness of Tito's power into something more graspable that produces humor rather than fear. Yet the dichotomy between Kauders' so-written "life and work" and Kauders' dog stages an alternate reality at work in the story, separate from that of the Kauders, whose life work comprised an all-encompassing bibliographic text. If we are not in the reality of Kauders' "life and work," our laughter need not have serious repercussions. Much as we are placed in a position of comfort through our sheer temporal distance to the Stalin years, the fictional quality of the narrative expands the innocuous space for humor. This space of unreality allows us to find humor in the fictionally Westernized "Josip B. Tito.” Josip Broz Tito, whose name would not be abbreviated into a Westernized middle name in communist Yugoslavia, is made into an American character of interpersonal familiarity. ${ }^{191}$ Notably, the space for humor is itself between two textual fragments.

This world of dichotomy is repeated into the story such that our knowledge of truth is constantly placed on shaky ground; our understanding of Kauders and his role in history is undermined by the absurd. Hemon creates a structural pattern for the reader: serious historical "truth" followed by parodic "fact." Since this form is repeated, we find ourselves at a point in which we always can laugh at the 'horrible truth,' as it will be followed by new knowledge that will turn that allegedly objective reality into a prelude to play. This becomes most effective as we learn that Kauders knew and conversed with high-ranking members of the Nazi party, a fact that reveals the story's power to create a different kind of historical record. Hemon takes the subject matter of violence and terror, and with it he creates a space of playful seriousness. We learn first that "Alphonse Kauders said to Joseph Goebbels: 'Writing is a useless endeavor. It is

\footnotetext{
${ }^{191}$ In fact, Hemon continues the joke into the "Notes" section of this story, in which he colloquially describes "the Yugoslav communist leader for thirty-five long years" as "J.B. Tito" (37).
} 
as though we sign every molecule of gas, say, of air, which—as we all know—cannot be seen. Yet, signed gas, or air, is easier to inhale.' Dr. Goebbels said; 'Well, listen, that differs from a gas to a gas"' (25-26). The colloquial tone through which Kauders and Goebbels converse is mirrored in Kauders' dialogue with Adolf Hitler: "Alphonse Kauders said to Adolf Hitler, in Munich, as they were guzzling down their seventh mug of beer: 'God, mine is always hard when it is needed. And it is always needed"' (27). Dialogue is not reserved for serious human interaction and reconciliation; it can also have restorative power in its use for play. That Goebbels and Hitler have become characters of jest invites Hemon's reader to laugh when he describes Kauders' impregnation of Eva Braun and her child's subsequent death: "Alphonse Kauders impregnated Eva Braun, and she, in the course of time, delivered a child. But after Adolf Hitler began establishing a new order and discipline and seducing Eva Braun, she, intoxicated by the Fuhrer's virility, sent the child to a concentration camp, forcing herself to believe it was only for the summer" (27). The subject matter of utmost seriousness is turned into nonsense; Hemon redefines our relationship to Nazism as one that can be comprehensible and can produce humor. Much as Ernst Lubitsch seeks to allow his audience to laugh at the image of Hitler in To Be or Not to Be, and to thereby combat Nazi oppression, Hemon takes similar steps as he constructs his literary narrative. And through dissonant shifts in style and tone, Hemon reminds his readers of the deeply human response of laughter, which we recover in the process of our reading.

For the margin of safety to function fully, Hemon also must formally detach his reader from the text, creating the distance to which earlier writers like Brecht allude. Since we are not asked to participate in the narrative as we are throughout other sections of Bruno, we can only look upon the text as an objective artifact. Given this distance between the reader and the 
narrative, Hemon establishes a metaphysical space that separates us from the life and work of Alphonse Kauders - those entities are detached materials on a page. Given that the narration provides no evidence of a human subjectivity behind it, rather only the bureaucratic, encyclopedic entries of a textbook, the reader is left to look upon the page rather than immerse herself in it. As such, the act of reading itself becomes fragmentary, jarred by narrative gaps. Not only is such distance created between the reader and the page, but the structure of the text itself betrays this divide.

Throughout “Alphonse Kauders," spaces appear between entries that leave a literal 'margin' in which we might be free to laugh—blank text between words, emblematic of the pejorative fragmentation in "Islands" and elsewhere in the novel, but with a markedly different function. Each 'entry' is itself a new paragraph, typically beginning with a fact about Alphonse Kauders, a remark he once made, or a thought he once had—all delivered through third-person narration. Between each of these entries is a spatial gap on the page:

Alphonse Kauders had a dog by the name of Rex, whose whelp, in the course of time, he gave to Josip B. Tito.

Alphonse Kauders had a mysterious prostate illness and, in the course of time, he said: 'Strange are the ways of urine.'

Alphonse Kauders said to Rosa Luxemburg: 'Let me penetrate a little bit, just a bit, I'll be careful.' $\ldots$

Alphonse Kauders said to Archduke Ferdinand's pregnant wife: 'Let me penetrate a little bit, just a little, I'll be careful.'

Alphonse Kauders, in the course of time, put a revolver on Gavrilo Princip's temple, for he had burned a bee with his cigarette (25-33).

While the formal quality of one-sentence entries mirrors the style of a reference text, the order of the entries functions much like the dissonant quality created at the beginning of the story in which information about Kauders shows its reader what the text could be (a work of history), 
only to upend that perception with a playful non-fact. Here, the text's encyclopedic form demonstrates that the "Life and Work of Alphonse Kauders" could be the stuff of reference texts, yet its structure breaks all reference-text forms: the entries are not ordered alphabetically, chronologically, or numerically, which distinguishes "Alphonse Kauders" from the serious literary work of "Islands" in which events proceed chronologically and appear in numerical order. In their repetition of Kauders' name, these entries also repeat colloquial phrases_- "in the course of time," which is never temporally demarcated for the reader, and sexually charged themes of double entendre that negate the historical significance of the figures involved- "let me penetrate a little bit" (25).

By the end of the story segment, the entries have yielded no 'useful' information. But notably, we are not in the static historiographic moment of "A Coin," in which violence makes such formal order impossible. In fact, we learn that Alphonse Kauders himself is a figure of little significance, with no place in such a conception of historical time: "Alphonse Kauders does not exist in the Encyclopedia of the USSR. Then again, he does not exist in the Encyclopedia of Yugoslavia" (29). In many ways, Hemon has thematically excised Kauders from history; the utility of the story and the character of Kauders do not rely on their place in a larger, objective History, but rather as a nodal point in the subjective histories of humor and knowability that can produce healing amidst the oppression of tyranny. "Alphonse Kauders" could be a work of bibliographic scrutiny with demarcated boundaries that represents very serious historical traumas, yet it is not. Thus the stakes of reading are located elsewhere; healing historical trauma, Hemon suggests, can only begin once we place ourselves in a position to laugh.

Hemon challenges the idea that histories tend to be singular or objective; the historical anecdotes surrounding tyrannical figures synonymous with Nazi Germany, the Soviet Union, and 
Communist Yugoslavia are reimagined as characters in narratives that have been spoken, logged, and perhaps even mis-remembered. Given this reinvention of a singular "History" of tyranny into many smaller "histories" that involve laughter and play, Hemon urges us to re-examine our response to historical records and facts. In distancing his reader and urging us to laugh at elements of suffering, "Alphonse Kauders" actually involves us in exposing the always-already subjective nature of history, and he positions us to reexamine our relationship to histories of human rights violations. How do we respond to objective narratives of historical trauma? Do such objective histories distance us such that it becomes difficult to manage them in the realm of everyday life? In "Alphonse Kauders," Hemon suggests that "History" contains the recuperative, alternate histories of play that he invents in the novel. In other words, within each grand narrative of political violence, there exists the possibility of alternate, playful ones that allow us to comprehend, and ultimately to oppose, mass violence; if large-scale crimes are intelligible enough that we can laugh at them, then we are in a better position to resist their repetition. In reading and laughing, we recover subjective histories, or a new historical knowledge, that might become a tool through which to combat tyranny.

In "Alphonse Kauders," the traditional lines between fact and fiction fluctuate, and Hemon uses them as a way to narrate a history of violence that promotes human recovery through humor. ${ }^{192}$ While the borders between fact and fiction limit the literary power of Darkness at Noon, Hemon suggests that such literary fluidity actually can invent modes of healing. The literary "facts" produced in "Alphonse Kauders" serve as constant reminders that

\footnotetext{
192 The line between fact and fiction in "Alphonse Kauders," it turns out, was blurred so well in the former Yugoslavia that readers of Hemon's work found themselves not only laughing at the story, but believing its contents. Info about people calling radio station and immersing themselves in the history of Alphonse Kauders and questioning Hemon's portrayal of Kauders. In Book of My Lives, Hemon explains how he originally read the "Kauders" story on a radio show, and callers began contacting the radio station with their own "facts" and stories about Alphonse Kauders, as if he had been a "real" historical figure (Hemon 58-59).
} 
all histories, just like Alphonse Kauders', are produced. Hemon urges us to see that the playful histories he invents, which seek to mitigate the incomprehensibility of tyranny, actually are legitimate forms of historical knowledge. For humor "can make visible unseen realities to reveal their ideological underpinnings as historical constructs" (Silberman 171).

To drive this point home, Hemon reflexively points to the amorphous spaces that exist among various dichotomies, including those of fact/fiction and self/Other. All such dichotomies might be understood as false, he suggests, and thus open to revision. For example, Hemon fictionally transcribes a quote from his protagonist in which “Alphonse Kauders said: 'I am myself, everything else is just stories"” (29). This statement quickly is followed by an explanation of Kauders' invention: “The very idea of creating Alphonse Kauders occurred for the first time to his (future) mother. She said to the (future) father of Alphonse Kauders: 'Let's make passionate love and create Alphonse Kauders.' Father said: 'All right. But let's watch some, you know, pictures"” (31). Kauders' own fictionality is confirmed reflexively by a subsequent history of Kauders' remark: "I-I am not a human being. I-I am Alphonse Kauders" (33). What is the first-person "I" doing here? The "I" that denotes the boundaries of oneself is markedly distinct from that depicted in Koestler's novel. While my reading of Darkness at Noon suggests that an "I" brings forth subjectivity and the reconstitution of selfconsciousness, in "Alphonse Kauders," the "I" becomes a marker of the contradictions inherent in writing history. The reality of the character no longer matters; instead, the stakes of Alphonse Kauders's existence lie in his inclusion within a farcical history. Kauders's existence allows us to find amusement in political jokes surrounding very serious subjects. His inclusion in the historical record, so to speak, opens up a space of comfort from which we can acknowledge the comprehensibility of violence. 
Hemon's "testimony" as to "The Life and Work of Alphonse Kauders," is not legal in nature, and it is not specifically his own. Rather, it is a narrative layered with distinct historical knowledges. The elements of the story suggest that histories can be created and re-created, and they can be playful just as readily as they may be pejoratively thwarted and silenced as in the Court of BiH. "Kauders" evidences a literary power to inventing a multi-perspectival history of human rights. Given its recasting of history through humor, the story presents us with a different kind of historical revisionism that actually prevents reification. In his formal creation of "margins of safety," Hemon provides us with the opportunity to laugh at the serious subject matter we encounter. And as we uncover the potential for playful "histories" within the oftenmonolithic narratives of war and totalitarianism, we recognize how Hemon's jokes make these narratives cognizable. In so doing, Hemon shows us how we can manage, and recover from, histories of violence.

\section{Conclusion}

Writing the nation from the condition of exile, Hemon's novel seeks a restorative justice that accounts for the inherent brokenness of the Balkans. In response, he provides a deeply textual method for human recovery. Guiding his reader into the "nowhere" spaces that he inhabits through the use of new narrative forms, Hemon offers a different kind of antidote to the injuries of forced migration. Rather than attempt to create a whole from the parts, the novel suggests that restoration occurs when we accept fragmentation and loss as a condition of being in certain geopolitical circumstances. As readers, we can collect these fragments into a new form of historical knowledge. When the ICTY cannot fully assume the multiplicities of victim suffering and reconciliation, the novel can start to provide this accounting. 
The Question of Bruno makes the reader central to the task of rehabilitation. Moving through acts of memory, translation, and historical recordkeeping, Hemon assigns his reader to bear witness to the spectacles of trauma, but moreover, he constructs a novel in which his reader must carry out acts of restoration throughout the text and even beyond. And in the course of the novel, Hemon even shows his reader how historical revision through the literary imagination actually can produce new kinds of knowledge through which to combat tyranny. For Hemon, humor becomes a narrative function that can produce victim recuperation. Providing an expansive tool for considering new forms of restorative justice amidst the ongoing violence that yields international criminal prosecutions, the novel celebrates the polyphony of literature and its potential to reimagine the contours of individual, national, and geographic histories. 


\section{Chapter Three:}

\section{The 'Terrible Genius of Literature': Post-Apartheid Reconciliation in Nadine Gordimer's The House Gun}

What is clear about South Africa is that reconciliation is the overriding political imperative that has shaped the forms of redress ... . But what price reconciliation?

—Roy L. Brooks

The writer is connected with time; that is the imagination. The State is connected with history; the State has only projection in place of imagination. For the writer, those small lights fuse in a single vision and become the Cyclops eye. It is what that eye sees that no other does. Only the writer him or herself can focus that beam as a social product - poem, novel or story.

\section{-Nadine Gordimer}

It's not that what is past casts its light on what is present, or what is present its light on what is past; rather, image is that wherein what has been comes together in a flash with the now to form a constellation. In other words, image is dialectics at a standstill. For while the relation of the present to the past is a purely temporal, continuous one, the relation of what-has-been to the now is dialectical: is not progression but image, suddenly emergent. Only dialectical images are genuine images; and the place where one encounters them is language.

-Walter Benjamin

How do we conceive of reconciliation? Is it a legal term? A social one? At its heart, the expression suggests a coming together of two disparate parts. For South Africa, reconciliation is a process immersed in systems of binary. Foremost, the phrase immediately invokes the political need to provide passage from the country's racist history to its post-apartheid future. Indeed, the 
Promotion of National Unity and Reconciliation Act 34 of 1995 (Act), which established the Truth and Reconciliation Commission (TRC), described national repair as a "bridge" between past and present. The act outlined the intellectual tools needed to country's address the past to carve out a better future. Of course, the nation's modern history is one defined by stark divides in both race and space. The laws of apartheid created dangerous racial and economic hierarchies while spatial segregation baldly partitioned the urban areas of the country.

Given these immense social and political fractures, a consideration of other binaries that underlie South African reconciliation must also include the salient tensions between the individual and the collective, and the private and public. At whom is reconciliation aimed, and does it inhabit a domestic or political space? These new dialectics in the post-apartheid era reflect upon significant distinctions between retributive and restorative justice, as well as the local/global dynamics that underpin remedial work in the South African government. Where does a novel fit into these questions? A reading of Nadine Gordimer's first post-apartheid novel, The House Gun (1998), opens up new ways of looking at the process of reconciliation in South Africa, the remedial capacities of the law, and the ability for jurisprudence and literature to outline the stakes of political healing after nearly fifty years of apartheid. ${ }^{193}$ As The House Gun tells us, "the terrible genius of literature can give license to politics" (52).

David Attwell and Barbara Harlow have articulated the ambiguities of post-apartheid repair, arguing that fiction "has taken upon itself the task of articulating this predicament." In fact, they explain, it has emphasized the "role of culture — or representation —in limiting or enabling new forms of understanding" (Attwell and Harlow 2). Since the mid-1980s, Stephen

\footnotetext{
${ }^{193}$ For additional ruminations on the relationship between imaginative literature and the effects of apartheid in South Africa, see Ewald Mengel, Michela Borzaga, and Karin Orantes, Trauma, Memory, and Narrative in South Africa: Interviews (Amsterdam: Rodopi Press, 2010); Ewald Mengel and Michela Borzaga, Trauma, Memory, and Narrative in the Contemporary South African Novel: Essays (Amsterdam: Rodopi, 2012); Ella Shohat, Taboo Memories, Diasporic Voices (Durham, Duke UP, 2006).
} 
Clingman has written on the political power of Gordimer's work and indeed has contended that The House Gun depicts the ambiguities of consciousness, subjectivity, and storytelling capacities in the transitional South Africa (Clingman, "Surviving Murder"). Yet despite Gordimer's global popularity and Clingman's frequent consideration of her work, The House Gun has been strikingly neglected within literary scholarship and has not received the attention of Gordimer's earlier novels. Written in 1995 just as South Africa had begun its work to heal the wounds of apartheid, The House Gun addresses key issues of reconciliation at the very moment of transition, and it presents a distinct portrait of the significant interrelation between law and literature.

Gordimer's work lends itself especially well to such investigation. Her novels have been described as "a mirror of South African history," tracing "the easy-going 50s, when blacks and whites could still socialize across the colour bar with virtual impunity, through the clampdowns of the $60 \mathrm{~s}$, when activists were driven into prison, exile, or the underground, to the painful $70 \mathrm{~s}$ and 80s," when Gordimer's work was banned by the state (Steele). In 1991 she won the Nobel Prize, an international acknowledgment that cast harsh light on the refusals of the official national policy. As much an activist as a novelist, Gordimer became heavily involved in the political trials of the early 1960s. At this early point in her career, Gordimer's work took on themes of both literary and legal justice. She grew acquainted not only with legal activists, but also with other freedom fighters in the early days of apartheid.

Gordimer has indicated that she does not write for a specific audience, yet her novels have gained tremendous popularity outside of South Africa. Recently, an article in The Guardian described her as a writer who is known in South Africa but primarily read abroad. In addressing the political climate distinct to South Africa, Gordimer creates literature that reflects upon 
contemporary questions of international jurisprudence. In a lecture given at Bennington College in the waning days of apartheid, Gordimer clarified the connection between her own writing and the politics of the country. Literature is always political, no matter its source:

When, overtly or implicitly, could writers evade politics? Even those writers who have seen fiction as the pure exploration of language, as music is the exploration of sound, the babbling of Dada and the page-shuffling attempts of Burroughs have been in reaction to what each revolted against in the politically imposed spirit of their respective times; literary movement which were an act - however far out—of acknowledgement of a relationship between politics and fiction (Gordimer, "Bennington").

Seemingly, The House Gun acknowledges its global readership, reminding us throughout the trial central to its plot that "the world was witnessing" (161), and that "[t]here are many to bear witness" (182).

Her work, as I will argue, has both local and global import. Even in addressing a specific South African political climate, Gordimer creates literature that engages deeply with international jurisprudence. In the waning days of apartheid, Gordimer clarified the connection between her own writing and the politics of the nation. In a 1990 lecture she asked, "When, overtly or implicitly, could writers evade politics?" (Gordimer, "Bennington"). Her inquiry brought together writers of imaginative fiction across multiple continents and at diverse moments of violent upheaval.

The House Gun opens with news of a crime in Johannesburg. In limited third-person narration, we learn about an affluent white couple: Harald Lindgard, a banker, and Claudia Lindgard, a physician. Their son, Duncan, has committed a murder. As the novel progresses, the Lindgards meet figures from Duncan's life with whom they likely would not have had contact but for his apparently inexplicable act. Hamilton Motsamai, a newly appointed black lawyer, represents the accused; Khulu Dladla lives in the house where the murder occurred. The novel moves from the Lindgards' meetings with Motsamai and Duncan to a lengthy courtroom 
scene in which Duncan is tried and convicted. Concurrent with his trial, the South African Constitutional Court hears the case of $\underline{S}$. v. Makwanyane (1995), in which it finds the death penalty illegal under the country's newly enacted constitution. By strategically centering the narrative around Duncan's crime without a focus on Duncan, Gordimer sets up larger dialectical questions concerning the reconciliatory measures enacted in post-apartheid South Africa.

This chapter begins by examining the archival materials connected to The House Gun, as Gordimer's drafts of the novel open up a discussion of the immediacy of reconciliation, the temporalities of justice, and the ways that the novel might imagine a distinct bridge between South Africa's juridical past and present. The following section considers Gordimer's novel in relation to the remedial aspects of the interim South African Constitution, the language of the Unity Act, and the processes of the TRC. Unmasking the binaries of jurisprudence, I suggest that these legal texts can be imagined as tools of symbolic reparation, thereby expanding our conception of reconciliation and opening up reparative possibilities in The House Gun. Accordingly, the third section turns to an analysis of the "grammatical fiction" at work in Gordimer's novel. While legal tools might provide a collective or national prospect for reconciliation, The House Gun uses language to display the restorative potential of interpersonal relationships. Next, I address spatial justice in post-apartheid South Africa. The question of land looms large in the country, ${ }^{194}$ and the novel shows us a way to imagine violence within urban space and to conceive remedial possibilities. The chapter concludes by considering the local/global dialectic that inhabits the literary and legal spaces of free South Africa.

\footnotetext{
${ }^{194}$ The South African Land Claims Court, established in 1996, deals with land claims that arise from the Restitution of Land Rights Act of 1994, the Land Reform Act of 1996, and the Extension of Security of Tenure Act of 1997. Land ownership and restitution has been the basis of many reform measures in the free South Africa. See, e.g., The Land Claims Court of South Africa [http://www.justice.gov.za/lcc/].
} 


\section{The Gordimer Papers: Negotiating Past and Present}

As Gordimer's first post-apartheid novel, The House Gun has been conspicuously neglected by critical attention, a quality that makes it fitting for a renewed investigation into the political impact of literature in South Africa. Because earlier drafts of the novel have survived in the archives, we are now well positioned to register Gordimer's negotiation of the boundaries between politics and fiction. ${ }^{195}$

A first change reflected in Gordimer's drafts is one that is simple but far-reaching: in moving from early drafts to the published novel, Gordimer abandoned the use of the historical past tense. The first sentence of the novel—"Something terrible happened"—-still stands within the conventional mode of historical fiction, closely allied, as Roland Barthes has shown, to one foundational principle of "historical discourse," which is "uniformly assertive, affirmative. The historical fact is linguistically associated with a privileged ontological status: we recount what has been, not what has not been, or what has been uncertain. To sum up, historical discourse is not acquainted with negation ..." (Barthes). In the original draft, the paragraph continued in the canonical mode of the simple past. But as the manuscripts record, in a series of brisk decisive strokes, Gordimer abandoned the convention of past-tense discourse and converted a series of verbs to the present tense. The site of the murder, originally placed within the stability of the past, enters the unstable realm of now: "The garden is the same one in which a cottage is sited. The house is the main dwelling on a property common to both." After the opening sentence, the force of the change is immediately felt: "Something terrible has happened. They are watching it on the screen .... It is Bosnia or Somalia or the earthquake shaking a Japanese island between apocalyptic teeth like a dog; whatever were the disasters of that time" (3). Additionally, when

\footnotetext{
${ }^{195}$ This chapter would not have been possible without the vast resources of the Nadine Gordimer Papers, housed at the Lilly Library at Indiana University, Bloomingtom.
} 
the novel first describes the relationship between Harald, Claudia, and Motsamai, the first draft originally noted experiences that the three "had in common." Considering the political implications of the grammatical past tense, Gordimer makes a swift shift to the present and inscribes instead what the three "have in common." The novel marks its static location in the mid-1990s, but the series of disjunctions_-Bosnia or Somalia or a Japanese island—discloses the demanding conditions of narrating a politics of the present, where catastrophes can leave traces well before they receive a name, a character, or an intelligibility. By working through the effects of this temporal shift, historical writing tends toward the past tense. But in altering her language to the present, Gordimer identifies The House Gun in opposition to historical writing; the novel does not depict South Africa's past, but rather an ongoing struggle toward reconciliation.

Since it relies on the immediacy of the present moment and the looming question of restorative justice, the novel emphasizes an exigency through language as it depicts the murder charge central to the plot. In the published version of the novel, Harald and Claudia first receive details of the crime "with the weight of [their] urgent gravity" (5). In subsequent pages, Claudia decides to telephone a lawyer about the murder to order the messenger to return to their home. The chapter ends sharply with three words: "Not tomorrow. Now" (18). These references to temporal immediacy mirror Gordimer's own writing and editing, which underscore the novel's move away from historical writing and her emphasis instead on the immediacy of social justice through imaginative narration.

Reading the novel, we are always in the present moment of its crime, but also in the present moment of South Africa's shift toward recovery. Gordimer turns the question of reconciliation into one that is always urgent; it resonates regardless of the time period in which the reader approaches the novel. This immediacy positions us definitively in the "now" moment 
of the past/present divide at issue in the country, suggesting that the work of reconciliation in the country is inherently ongoing. For both Gordimer and the legal practitioners shaping the judicial landscape of the free South Africa, justice is deeply connected to bridging the past and present. After enduring the dividing wounds of apartheid and the brutality of the regime, what does it mean to "get it right," to enact justice in the country? In The House Gun, the answer is twofold. On the one hand, Gordimer must be just to the immediate post-apartheid period as she works out her own relationship to the political transition in literary representation. On the other, the novel must illuminate the distinctions between retributive justice and the restorative possibilities of law and literature for the country.

For Gordimer, performing literary justice requires a "true" and accurate representation of South African jurisprudence; Gordimer insists upon legal accuracy in the novel. In order to speak to the country's political climate, The House Gun must abide by the legal constraints imposed upon South Africa's methods for seeking justice. Gordimer's drafts reflect this reality as she strives to "get the law right." At the end of a letter to her editor at Farrar Straus, Gordimer included a postscript that requested an immediate edit prior to publication: "Just discovered that on page 163 a rather important word is left out. The second line of the underlined passage should read: reasonable and justifiable in an open and democratic society. As this is a quote from a law it must be accurate." For her novel to have legal resonance, it must engage in South African political realities. The reader must not experience the text as fiction; for Gordimer, the two are inherently interrelated, and the novel can serve as a political actor in lieu of a qualified state.

In an address at the PEN Congress in 1986, Gordimer tied the political acts of the state 
intricately to those of the fiction writer. ${ }^{196}$ "The State has no imagination," she espoused. "The State has no imagination because the State sees imagination as something that can be put into service. The Writer is put into service by his imagination; he or she writes at its dictate." She emphasized that the political imagination comes in the form of "a social product—poem, novel, or story." "Sometimes," she addressed the crowd, the writer can "feel at home" within the state. And even in political situations that stymie human rights, Gordimer emphasized, "the Writer's imagination has visualized an ordering of human lives that seems to be attainable by the projection of a State not yet created." In another lecture given in Dakar in $1989,{ }^{197}$ Gordimer called upon writers and readers to contribute to politics through literary endeavors. "They have been called up by history. They have been called up by justice," she spoke. She highlighted the importance of "a format and distribution process" that is capable of bringing novels arising out of a political consciousness into everyday life.

Ultimately, for Gordimer, literature becomes "a form of political writing." 198 Within the space of the novel, she told a group of writers at Bennington College in 1990, "here was somewhere where the truth about being alive might lie." ${ }^{199}$ Within imaginative narratives, she further explained, "the harsh lessons of daily existence, coexistence between human and human . .. could be made sense of in the ordering properties of the transforming imagination, working upon the "state of things." Perhaps more than her earlier novels, The House Gun's setting in post-apartheid Johannesburg, and within its spaces of jails and courtrooms, seeks to illuminate the equal ways in which law and literature act upon one another. Can literature expose the limitations of courtroom retribution and mercy? Can the novel emphasize the immediacy of

\footnotetext{
${ }^{196}$ Nadine Gordimer, “The Writer's Imagination and the Imagination of the State.” Address to PEN Congress, 1986.

${ }^{197}$ A separate version of this speech became an address Gordimer gave at Harvard's literary exercises in 1991.

${ }^{198}$ See Gordimer, "Writing and Being."

${ }^{199}$ See Gordimer, "Bennington lecture."
} 
rehabilitation such that it pushes upon legal temporalities, opening courtroom spaces traditionally reserved for retributive justice to models of restoration and recompense?

Recrafting the language of law within the novel opens up the temporal binaries in South African jurisprudence to a more globally looming divide between retributive and restorative justice. Through narrative, can South Africa be remade to focus on the forward-looking goals of rehabilitation, leaving behind the backward-looking aims of retribution? Surely, the juridical aims of the free South Africa point in this direction. Turning her novel into a political text, Gordimer reconciles issues of temporality with forms of justice, creating a novel that formally mirrors a legal document. Hers looks primarily toward a South African future founded upon principles of mercy and recovery. The binaries of past/present and retributive/restorative fit together nicely: retributive justice generally falls into pastness as it administers justice in the form of punishment for bad acts, while restorative justice aims toward a future enhanced by avenues for rehabilitation. The House Gun itself looks ahead, imagining what the South African court system could be in light of the country's new reconciliatory foundation.

To aptly set the stage for a rehabilitative shift in the courtrooms of South Africa, Gordimer pays particular attention to legal form. These procedural truths are twofold, mirroring the decorum of the courtroom while also attending closely to statutory and common law. In crafting the specific language in Duncan's trial, Gordimer referred to well known apartheid-era case law. ${ }^{200}$ George Bizos provided this case printout to Gordimer for use in research for the novel, and she transfers verbatim much of the court's reasoning in the case to the trial scene in The House Gun. The language of the court in that historical case, Kalogoropoulos, becomes involved in the crafting of the novel, turning it into a palimpsestic text of sorts. At once, the trial

\footnotetext{
${ }^{200}$ See, for example, S v. Kalogoropoulos, Appellate Division, 1992 Nov 13, 1993 (1) SACR 12 (A)]; In the matter between: Arthur Kalagoropoulos and the State, Case No. (A quo) 199/1988; appeal court 85/90.
} 
in The House Gun follows South African legal precedent by using specific language from Kalogoropoulos, but it also inscribes that apartheid-era law into a post-apartheid court. Dealing with legal history in the present moment allows Gordimer to create a literary pathway from the harms inflicted by the apartheid juridical spaces to the rehabilitative focus in the new court system. Notably, Kalogoropoulos is from 1990 - saliently decided prior to the seeds of transition. In hearkening back to apartheid-era South African legal procedure, Gordimer illumines the injurious roots of the law in her country, but she also uses it as an opportunity to transform that law into one newly focused upon the reconciliatory measures imagined in the TRC and corresponding legislative texts. By paying close attention to the formal and aesthetic truths of the law, the novel transforms the juridical spaces traditionally conceived as realms for retribution into ones of immediacy that move away from questions of perpetrator punishment and into the realm of restorative justice.

Accordingly, the novel represents a precise moment in South African history, temporally bifurcated by the end of apartheid. When does the novel take place? It betrays its temporal specificity only once, describing the murder by "that day, that night, Friday, 19th January, 1996," when "a man was found dead in a house he shared with two other men" (15). It is at once conditioned by years of apartheid and institutionalized racism, and therefore marked by a distinct period in the twentieth century. At the same time, however, it is saliently in the present as it strives to accentuate the immediacy of rehabilitation in a nation with entrenched political wounds. In the country's recent past, like in The House Gun, "something terrible happened": the country witnessed the institution of apartheid in 1948, and that violent occurrence enabled nearly forty-five years of violent state-perpetrated crime that shaped the sociopolitical atmosphere and physical spaces across the country. Through seemingly incidental marginalia, the novel reminds 
us that the country's fraught past underlies its story of the present. Describing Motsamai's physical appearance, Gordimer depicts "a new form of national sophistication" (40). "In his elegant grey suit," the novel reads, "here is a man who has mastered everything, all contradictions that were imposed upon him by the past" (40). The past grows increasingly salient in the courtroom, designed as a setting in which prior criminal acts can be put on trial and justice rendered. In the South Gauteng High Court (known colloquially as the Johannesburg High Court), the novel discreetly alludes to the pervasive question of race as it describes the newly appointed judges: "It is impossible_-because of the past, and even more because of the changes of the present - not to see them first as an impression of their colours. A black woman with the high cheek-bones and determined mouth of one of her race who has succeeded against the odds, a black man with the heavy-set head in thick shoulders of traditional dignity turned academic" (134-35).

Considering Gordimer's immense focus on South African jurisprudence and the political role it has to play in her novel, the archive reveals a second, rather different strain of revision from the grammatical tense referred to earlier that concerns Gordimer's close, complex relation to George Bizos. A scrawled note in the margins of the manuscript reads, "Ask George B." Gordimer now confirms that she sent an early draft to George Bizos, seeking his legal expertise. ${ }^{201}$ She herself has described Bizos as a famed human rights attorney, "known worldwide as Nelson Mandela's defence lawyer in charges brought against Mandela, President of the African National Congress, during the apartheid regime in South Africa." He also played a significant legal role in Mandela's path to freedom as well as in anti-apartheid movements across South Africa. Again in Gordimer's praising terms, Bizos is one who "fearlessly defended other Freedom Fighters against apartheid," and who later founded the Legal Resources Center,

${ }^{201}$ Correspondence with Nadine Gordimer. August 2013. 
which provides assistance to defendants whose Constitutional rights have been violated. Bizos has acted as senior counsel in defense of numerous freedom fighters in the struggle for a free South Africa, thereby shaping the historical record in the country's courts. At the same time, as I have noted, Gordimer's drafts of The House Gun reveal that he has carefully considered how literature should represent the courts and their role in a culture of justice. With Bizos's involvement, Gordimer's aim to reconstruct the temporal space of the South African courtroom comes to fruition.

Gordimer's manuscripts reveal how heavily she relied on Bizos's legal experience when crafting the language of The House Gun. Bizos effectively plays a role in the legal authorship of the novel. Just as Gordimer's career has been defined through her work in both literary and political realms, Bizos's involvement in The House Gun illumines the significant role that literature plays in crafting the imaginative potential for South African jurisprudence. Bizos's proposed revisions became the foundation for the legal procedure of the novel.

Seemingly inconsequential distinctions among legal "findings," "holdings," and “opinions" give way to significant issues of jurisprudence; Gordimer's literary inquiries beget serious legal questions. Focusing on the novel's lengthy courtroom scene, Gordimer asked Bizos such questions as whether she had crafted a "correct kind of opening statement?" or the "correct wording?" or the "correct sequence/procedure?" Later referring to actual case law used in her research for the novel, Gordimer wrote to Bizos, "I note that, in a judgment you lent me, chapter and verse was given. Must I follow this throughout? I haven't been consistent, as you'll see.”

In addition to her concern with the lingua franca of courtroom, Gordimer's focus on the style of jurisprudence blends into a subjective realm traditionally reserved for persons and spaces outside the courtroom. In the text of the novel, the judge describes Duncan's testimony, saying 
that his "manner of delivery" had "the characteristics of truth" to "those like myself and the assessors, accustomed to the tenor and timbre of lying." A margin note in Gordimer's handwriting highlights the judge's remarks, and she comments, "I want my judge to show some human characteristics; irony, some wry comments, etc." Later in the novel, when the judge refers to the "crime passionel" that Duncan committed, Gordimer's draft questioned in the margin, "Is this sarcasm allowable for a judge?" When the judge subsequently refers to "the usual revenge of dishonoured lovers of one kind—or both," Gordimer notes that this is "a wry and worldly dig at gays." Is it "permissible in a judge?" she asks Bizos.

When it comes to questions of procedure and the precise language of the law, the drafts continue to reflect changes that Gordimer made based on Bizos's comments. At the moment in the novel wherein the judge hands down the guilty verdict against Duncan, Gordimer's draft originally read:

The unanimous verdict of the court is that Duncan Linmeyer is found guilty, with extenuating circumstances, of the murder of Carl Jespers. Sentence will be passed tomorrow. ... Mr. Msimang, if you wish to call any witnesses in mitigation before the handing down of sentence, you have my permission for provision to be made for this in the customary procedure. ${ }^{202}$

In Bizos's handwriting, pen marks show procedural edits to much of the paragraph. He crosses out all lines after "Sentence will be passed ..." and indicates that that Gordimer should begin a new paragraph. He indicates that some of the information in the draft text need not be said, as "you no doubt want to consider whether you want to call any evidence." He then explains that "Counsel for the State may also want to consider his position. Subject to what you may have to say, propose to adjourning until tomorrow." The final version of the novel takes these procedural notations as significant. In the published print, the same section of the novel reads:

The unanimous verdict of the court is that Duncan Peter Lindgard is found guilty, with

\footnotetext{
${ }^{202}$ Gordimer changed the names of several characters between drafts and the final published version.
} 
extenuating circumstances, of the murder of Carl Jesperson.

I propose to adjourn the matter of sentence until ten o'clock tomorrow morning.- (267).

Here, Gordimer uses Bizos's language to turn the temporal stagnancy of the courtroom into one that is always immediate, looking toward tomorrow.

The proximity of the political and the fictional is most visibly registered in the novel's account of the landmark trial, $\underline{\mathrm{S}}$ v. Makwanyane, which declared the death penalty illegal in the country. As we read The House Gun in present-tense form (regardless of our own varied temporal locations), the country's move to abolish the death penalty—-the most salient legal shift from punitive aims toward restorative ones - and to engage in acts of amnesty and reconciliation loom large. Indeed, while the novel focuses on a specific crime and its repercussions, Gordimer's text actually presents significant questions about the broad-reaching history of the moment in South Africa and the connections between justice and reconciliation.

The question of capital punishment bears upon key questions of transition and reform central to the larger "new South Africa" that Gordimer describes earlier in the novel. Makwanyane was a landmark case in the South African Constitutional Court, as the judgment declared the death penalty unconstitutional in the country. In her research for The House Gun, Gordimer took notes on printed copies of Makwanyane. Within the plot of the novel, as I have mentioned, a local court tries Duncan for murder while the Constitutional Court, located less than two kilometers away, hears the famous death penalty case. Gordimer's narrator describes it as "a test case for the most important moral tenet in human existence" (136). Using precise language from the Constitutional Court's interpretation of the South African Constitution's Bill of Rights, Gordimer supplies the novel's account of the capital punishment arguments:

The atmosphere is that of a lively debate, with the abolitionists' lawyers basing their contention on sections of the Constitution's Bill of Rights, which they quote (in the aura of lilies the young woman at his right scribbles down what he side-glances to read: 
Section 9 guarantees the right to life Section 10 protection of human dignity Section 11 outlaws cruel inhuman degrading treatment or punishment.) The abolitionist Counsel's back, which is all that can be seen of him from the fifth row as he addresses the judges, sways with conviction as he gives his interpretation of Section 9: the first principle is the right not to be killed by the State (136).

But more significantly, Gordimer's own questions about the court's language are telling. In a recent case,${ }^{203}$ the Constitutional Court considered whether retribution could be a legitimate "objective" in light of the country's decision to effect a "constructive transition to a democratic order" founded upon principles of restorative justice (31). At the bottom of one of the pages of the decision, Gordimer underlines the court's understanding that perpetrator amnesty "has to be evaluated having regard to ... the very important relationship which the act perpetrated bears in proportion to the object pursued" (31). In the margins, Gordimer makes a note to herself: "What 'object,' moral values aside, was bigger, apartheid perpetration or liberation? Which was greater?" Indeed, the question resonates in The House Gun as Gordimer navigates the divide between South Africa's destructive past and its rehabilitation potential for the future.

As the novel questions the legitimacy of retribution, it sets the stage for a post-apartheid period marked conspicuously by reconciliation. Like the drafters of the new Constitution, Gordimer tests ways of reconciling the country's past with its present. Here, Duncan's storyline intersects to pose questions about retributive and restorative justice. For both Duncan and the defendants named in Makwanyane, the cases summon "that ancient edict" that "thou shalt not kill" (136). Is human recovery backward-looking, absorbed in the nation's political history and its widespread use of the death penalty? Or does it look forward, focusing always on the possibilities of the present moment?

In many ways, Gordimer creates a new legal text with Bizos's assistance, enacting a form of literary justice. As I have noted, Bizos suggests that the trial language emphasize an

\footnotetext{
${ }^{203}$ See AZAPO v. President of the Republic of South Africa, CCT 17/96, Constitutional Court, 17 July 1996.
} 
"adjoining until tomorrow." He supplies literary language that has its root in law; within it, the court always looks forward, "until tomorrow." Gordimer then employs that language to show how literature might remake judicial precedent. She transforms the traditionally retributive space of the courtroom into one that looks ahead toward rehabilitation. Bizos's involvement underscores the high stakes of this work. Can The House Gun reshape the temporal trajectory of the law, as I have contended, defining South African justice as a process that is always ongoing?

Alluding to the injustice that dwells in her country's past, Gordimer initially presents the court as temporally stagnant. When Duncan's trial begins, we learn that "there is only this court, this time, this existence" (182). As the Lindgards await the court's verdict, Gordimer writes, "Tomorrow it will be over. There will be the verdict" (237). For when a verdict is handed down, "all other communication, within and without, is stilled; all is ended. This is the last word" (251). Given the connection between this pejorative atemporality and retributive justice, Gordimer's description of the Johannesburg prison — a space of punishment—is not surprising: "To be in prison is to be dead in connection with consciousness outside, to exist there only in the past tense" (25). Indeed, the novel marks the retributive space of the prison as connected to the country's apartheid past and oppositional to the aims of the TRC: "At that place, the prison, to which [Harald and Claudia] were inescapably headed, they were received with the kind of courtesy that is learnt in public relations training of a new police force intended to obliterate the tradition of the racist and brutal authority of the past. Anyway, the officer in charge is an Afrikaner" (29).

Despite significant political shifts, South African spaces of justice remain imperiled by the country's past. For example, the image of an Afrikaner officer at the prison reminds the Lindgards — and us — of the very recent apartheid prison images of white Afrikaner jailers and 
non-white prisoners. It is as if the aesthetic space of the jail in free South Africa is endangered by the past, while also carrying a visual reminder of what used to be.

Yet even as The House Gun stages juridical spaces that appear rooted in a tradition of assigning justice, the novel goes on to re-imagine the South African courtroom as an opportunity for restorative ethics. Unlike a traditional trial in which justice "is done," Gordimer creates a justice system that looks forward, focusing on the reconciliatory goals of rehabilitation and mercy. The temporally stagnant courtroom space becomes one of social immediacy. After handing down the verdict in Duncan's case, the judge remarks, "the question of sentence is a very difficult one; it must not only act as a deterrent but there also must be a measure of mercy" (273). Here, the judge highlights the tensions between retributive and restorative justice. After sentencing Duncan to seven years in prison, the judge makes no further comments; the novel reads starkly, "Over" (274). It seems as if the judge has chosen to maintain the retributive elements of the courtroom, yet the word "over" does not refer to a temporal end. Rather, it is a point in an ongoing story; the chapter ends by emphasizing the newly continuous temporality of justice: “Over. It's beginning” (276). The novel turns a concluding phrase into one that contains within it a future potential. Justice is never over, but remains ongoing.

While it may have distinct temporal roots, legal justice is an ongoing process visualized by its forward movement: "Signals of life, from everything, in spite of everything" (285). Harald, too, was "not able to think of justice as he used to" (58). By redefining the temporality and purpose of courtroom justice, Gordimer offers a literary bridge between South Africa's past and present, showing that the apartheid models of justice have been replaced. The manner in which she reshapes the temporality and purpose of jurisprudence resonates in the language and legislative intent of the legal documents that politically shape the new South Africa. 
The novel challenges the premise that justice can be concluded. By redefining the temporality and aim of the courtroom, Gordimer offers a bridge between South Africa's past and present, depicting a space in which apartheid models of justice are replaced with those that focus on future reconciliation. The manner in which she reshapes the purpose of jurisprudence resonates in the language and legislative intent of the legal documents of the new South Africa. While both approving commentators and critics question the efficacy of the South African Constitution and the TRC when it comes to objective evidence of reconciliation, I argue that the novel shows us how to reassess the symbolic power of the law.

\section{Reparation and South African Law}

Instead of viewing the Constitution simply as a legislative document that enacts law, can we conceive of it as a form of symbolic reparation? American constitutional law, which largely influenced the international norms infused in the post-apartheid Constitution, has long recognized the value of symbolic judgments. Typically, reparation schemes can be categorized as either backward-looking or forward-looking in nature. ${ }^{204}$ The backward-looking reparation models tend to be tort-based, meaning that they involve a lawsuit to receive damages for past crimes. Forward-looking models seek remedies that might allow the injured party to heal in the future, which in practical terms often means an apology from the perpetrator or funding for future reconciliatory initiatives. The South African Constitution contains within it the necessary elements for both models of reparations. In the decades since the TRC has come to a close, practitioners and historians have criticized the outcomes of the Commission. Rather than contend with the success or failure of its grand narratives, I suggest that, if we view the laws of free South Africa as laying the phenomenological ground for human restoration, we might be

\footnotetext{
${ }^{204}$ See, for example, Ogletree for a discussion of the contentious tenets of the legal reparations debate.
} 
able to place the transitional years of the country within a new perspective. Here, the language of law can offer remedies that can only be illumined through a concurrent reading of literature.

If The House Gun envisions a newly reparative legal order, can we recover those same elements in the very legal texts working to reshape the county? Fundamentally, the South African Constitution seeks to start anew by imagining all of its citizens as victims of apartheid; it provides protections in the form of fundamental rights to account for the injuries of apartheid. Its potential should be seen as repairing a whole nation, rather than a marginalized racial or ethnic group. Throughout the apartheid years and into the early years of transition, antiapartheid activists documented the deep-rooted question of whether the people of South Africa could "trust the institutions of justice" (Simpson). As if emphasizing a shift away from traditional conceptions of a courtroom tainted by apartheid policy, the Preamble to the Constitution declares, "[T] between men and women and people of all races." Further, its purpose is explicitly "the promotion of national unity." The Constitution, that is, intended to reconcile disparate elements in the country, to repair the injured racial relations among its citizens. The document shows its intention to move from past to present, much as Gordimer does for us in The House Gun.

The Court has emphasized the Constitution's remedial capacities, construing it as reparative. Addressing the question of the death penalty as if atoning for its past use, the Constitutional Court redefines it as abhorrent to base standards underlying international human rights law. Notably, in The House Gun, Gordimer uses Makwanye as a "test case" concerning the right to be free from state violence. The matter is complicated, as the same apartheid-era government that exploited the death penalty for political purposes also enacted the urban segregation that enabled a climate of criminality to arise; segregation created the social 
atmosphere that many argue has caused the acts of rape and murder that afflict Johannesburg. Gordimer's work in The House Gun invokes those issues as it addresses the death penalty.

The Afrikaner National Party (NP) took power in 1948 and instituted apartheid policies, and soon it began using the death penalty as "a tool of State repression" (Bouckert 291). The government eventually expanded its use of capital punishment to include both violent and nonviolent political acts. For example, "sabotage" became a capital crime in 1962. By 1963, political actions affiliated with the Marxist left were marked as crimes punishable by death, and in the mid-1960s the NP displayed its arbitrary institution of capital punishment and its political power when it executed sixty political prisoners (291).

When Makwanyane came before the Constitutional Court in 1995, the Court was so new that its justices hadn't yet been chosen. Indeed, the freshly minted quality of the Court meant that Makwanyane could become its own "test case" of sorts, much as Gordimer suggests in The House Gun. Significantly, the Court's decision to abolish the death penalty employs the language of repair. The majority decision emphasized that the Court strongly weighed the "history and circumstances" of the country." That is to say, the nation's historical injuries would color the Court's attempt to repair its socio-legal present. Providing its own emphasis on reparation, the Court reiterated that transition from apartheid calls for "a need for understanding but not for vengeance, a need for reparation but not for retaliation" (85). Indeed, the Court cited this language four times to emphasize a shift "from retaliation to reparation" (142).

Here, the Court destabilizes the binary of past/present, showing the law's flexibility; it can embody a shift from the backward-looking quality of retributive justice to the future-leaning force of restorative justice. Capital punishment, the Court explained, denies the possibility of human recovery, "makes any reparation or correction impossible" (156). Indeed, the justices 
considered theories of retribution antithetical to the spirit of the Constitution and to the creation of a new South Africa (85). If the Constitution contains such possibilities for restorative justice, can the legal texts that arise from it also carry reparative potential?

Arising out of the Constitution, the Unity Act provided for the creation of the TRC. It articulated its plan to provide "a historic bridge between the past of a deeply divided society characterized by strife, conflict, untold suffering and injustice, and a future founded on the recognition of human rights, democracy and peaceful co-existence for all South Africans." While we cannot pretend that "catharsis and community healing are automatically embedded in the TRC process" as many critics have remarked, the language of the Act can help us to think through the various meanings of reparation in South Africa (Simpson).

To consider the symbolic effects of the TRC, we need to understand the ways its alleged 'grand narrative' has come under massive fire. But what precisely is its grand narrative? Many commentators might say the Commission was designed to effectuate complete and lasting reconciliation across social, racial, legal, and spatial lines in post-apartheid South Africa. Indeed, the TRC encountered much criticism during its years of operation (1996-1998) and in the nearly two decades that have passed since its construction. Critics point primarily to statistical evidence that the country is not 'reconciled,' while others allude to the fact that the TRC allowed perpetrators to evade 'justice. 205

In light of both international norms and the specific language of the Constitution, the South African Attorneys' Journal De Rebus anticipated challenges to the Act nearly as soon as it was passed. Most notably, the article questioned whether the Unity Act set up a system in which "reconciliation and justice are mutually exclusive concepts" (392). Traditionally, reconciliation is viewed as something "that courts cannot do" (343). And likewise, many practitioners argue

\footnotetext{
${ }^{205}$ See Simpson for a description of the many critical approaches to the TRC's successes and failures.
} 
that a truth commission cannot enact justice; the two are naturally opposed. Other legal commentators emphasized this divide in the years immediately following the TRC's closure. For example, in an article published in Human Rights Quarterly, prominent American constitutional law scholar Owen Fiss argued that "[t]he proceedings conducted by the Commission did not satisfy the elemental requirements of justice. Justice requires a public or official judgment of wrongfulness, or even more, illegality, as well as the imposition of some burden or punishment on the perpetrators of the wrong" (60). For Fiss, the TRC "sought reconciliation rather than justice" (60). But Fiss and other critics sidestep the important notion of restorative justice. Legal theory conceives of the term as one that connects notions of repair and justice. Rather than provide immediate evidence of reconciliation, can repair become part of a legal toolbox to dismantle racism and related injustices? Here, we return to the question posed earlier in relation to the South African Constitution: can reconciliation be a symbolic form of justice, and can that figurative weight carry political effects?

The precise language and intent of the Unity Act are instructive here. Specifically, the framers intended it "[ $[\mathrm{t}] \mathrm{o}$ provide for the investigation and the establishment of as complete a picture as possible of the nature, causes and extent of gross violations of human rights committed during [apartheid]." It provided amnesty "for persons who make full disclosure of all the relevant facts relating to acts associated with a political objective," while equally focusing on "the rehabilitation and the restoration of the human and civil dignity of victims of violations of human rights." Intended to promote reconciliation among "all South Africans, irrespective of colour, race, class, belief or sex," the Act emphasized the necessity of "establish[ing] the truth in relation to past events as the motives for and circumstances in which gross violations of human rights have occurred, and to make the findings known in order to prevent a repetition of such acts 
in the future." Notably, the Act never promises reconciliation. Rather, it sketches out the means needed to promote it, thereby reshaping the ways in which South Africans might imagine their relationship to one another and to their country's violent past.

Relying on that language of law, the Act actually carves out a set of tools to be used for remedial and reconciliatory purposes. The objectives of the Commission include:

(a) establishing as complete a picture as possible of the causes, nature and extent of the gross violations of human rights which were committed during the period from 1 March 1960 to the cut-off date, including the antecedents, circumstances, factors and context of such violations, as well as the perspectives of the victims and the motives and perspectives of the persons responsible for the commission of the violations, by conducting investigations and holding hearings;

(b) facilitating the granting of amnesty to persons who make full disclosure of all the relevant facts relating to acts associated with a political objective and comply with the requirements of this Act;

(c) establishing and making known the fate or whereabouts of victims and by restoring the human and civil dignity of such victims by granting them an opportunity to relate their own accounts of the violations of which they are the victims, and by recommending reparation measures in respect of them;

(d) compiling a report providing as comprehensive an account as possible of the activities and findings of the Commission contemplated in paragraphs (a), (b) and (c), and which contains recommendations of measures to prevent the future violations of human rights

The verbs are foundational ones, used to create a new social frame: to establish, to facilitate, to compile. The document strategically shies away from language of completion or conclusion.

The text of the Unity Act tracks interestingly with Gordimer's remaking of legal justice in The House Gun, which emphasizes the immediacy of human recovery. Much as Gordimer refigures juridical procedure as ongoing and atemporal, so the Act reworks the juridical form to conceive of the law as a primary venue for restoration. The law is not static, but instead provides for ongoing processes of reconciliation. The novel suggests how this might take shape in the law; Gordimer introduces us to a concept that we can apply to considerations of the Act and the resulting TRC. The TRC wasn't intended, as one scholar has written, to "perpetuate the myth of 
the so-called rainbow nation where everyone claims to love one another, but to reveal the serious divide that does exist" (Boraine 343). Identifying and exposing the wounds of the nation, and interlocking that process with the language of new law in South Africa, might set the country's judicial system on a course toward "justice" that reconciles retribution with the tenets of restoration. It may be that the key lies in the reparative possibilities the Constitution established and set in motion, rather than the conclusion upon which it rests (344).

If reparation can be recast through a reading of the law, why turn to the novel? Addressing the private/public dialectic central to her earlier novels, ${ }^{206}$ Gordimer returns to domestic spaces in The House Gun where tensions play out to ask what reconciliation means for interpersonal relations in South Africa. The novel illumines complications of human repair. Specifically, can we ever ask the law to provide this kind of remedy? And can fiction depict the law's limitations while simultaneously displaying its legitimacies, thereby revealing the varied nature of remedy in South Africa? Just as the ANC framers of the Constitution relied upon diction to underscore the newly collective and equal nature of citizenship in the country, Gordimer draws out this linguistic equality in the private sphere through the Lindgards' relationships with one another, and with the "Other" characters brought together through the trial. Transitional violence, in this case, catalyzes certain forms of reconciliation.

\section{Grammatical Fictions of Race and Class}

Through language, Gordimer's novel reawakens the notion of the "grammatical fiction" of pronoun use, introduced in Koestler's Darkness at Noon, but she transforms the term here for contemporary use in South Africa. Rather than use the first-person "I" to investigate individuality and self-consciousness, Gordimer relies upon third-person narration to deconstruct

\footnotetext{
${ }^{206}$ See, for example, Gordimer, July's People, Burger's Daughter, and The Conservationist.
} 
the pronoun - underscoring the binaries that often define us. Through the repetition and variation of "he, she," The House Gun illuminates the artificiality of the classifications of persons. In addition, the novel offers a fluid understanding of language that stands in stark relation to the limited fluidity of bodies in the apartheid-era urban spaces of South Africa. Through her emphasis on third-person pronoun use, Gordimer shows us how literature can break down harmful dialectics where socio-legal structures encounter difficulties. Accordingly, it displays a distinct power of language and literature, interwoven with national and global politics. For Gordimer, the grammatical fiction is more blatant than for Koestler, revealing that the language by which we identify others is in fact a fluid fiction from which we can break; we can reimagine our own identity, the identity of others, and the relationship that lies in between by engaging with narrative fiction.

Gordimer introduces us to The House Gun from an objective, outside perspective. Prior to presenting Harald and Claudia as protagonists in the text, the novel marks them only by an unidentified pronoun when it tells us: "Something terrible happened. They are watching it on the screen, with their after-dinner coffee cups beside them." The pronoun here invokes an immediate distinction between us, as readers, and them, the characters of the novel. Given the politically fraught construction of the us/them binary, this distinction is not a benign one for Gordimer. It carries with it a long history of racial and social hierarchy, which has particular import in South Africa. Much as the jurisprudence of the free South Africa disrupts the binary between its past and present by shifting the conversation to tensions between retributive and restorative justice, the novel undermines another apartheid-created divide. Here, Gordimer destabilizes the gap between us and them, ${ }^{207}$ moving beyond questions of postcoloniality in her

\footnotetext{
${ }^{207}$ Destabilizing this binary has long been a task of Gordimer's, which we can see if we look back to certain of her banned apartheid-era novels, such as July's People.
} 
transitional nation.

Invoking these historically injurious divides and their accompanying ideologies, Gordimer upends our assumptions about what an us/them binary means. The pejorative association of this binary is toppled, as the "them" to which the text refers-Harald and Claudia — turns out actually to be a traditional "us" — an educated, white reader — within South African politics. Apartheid created traumatic fractures between races (white/not white) and economic statuses (wealthy/poor), and these divides reflect upon Gordimer's emphasis on pronoun dialectics. Soon after identifying the couple by the pronoun that implies an us/them relationship between the reader (us) and the characters (them), Gordimer reconfigures our understanding of its use. The novel describes the surroundings in which "they" live, and in addition to visualizing their "after-dinner coffee cups beside them," we learn that "they made the decision to give up the house and move into this townhouse complex with grounds maintained and security-monitored entrance" (3). In this universe, "they" are like "us"- a reading elite, and part of a class that learns about violence on a television screen rather than being its perpetrator or victim. $^{208}$ As Harald and Claudia watch a television set upon which something terrible happened, the reflexivity of the moment mirrors ours; very likely, Gordimer's reader merely observed the injurious politics of South Africa unfold across a television screen.

But if we are like "them," is the us/them binary destroyed? Or does it simply create a different divide among persons, with a separate "them" lurking in the novel? Gordimer plays on our own trappings within racist ideology that remain even in the transitional South Africa. Indeed, as I will discuss later, that very language created social conditions that catalyzed and exacerbated continuing inequalities and urban violence in the country. The House Gun exposes

\footnotetext{
${ }^{208}$ Indeed, studies suggest that Gordimer is primarily read among a western, (white) reading elite. See, for example,
} Steele. 
that ideology as a political fiction.

Within the first page of the novel, Gordimer reveals another layer of the grammatical fiction. After illuminating the fluidity and fictionality of the us/them binary, she then invokes another linguistic divide. This time, the novel begins to describe Harald and Claudia through the heteronormative use of "he, she." Shifting away from descriptions of Harald and Claudia as "they"-Gordimer still has yet to identify either character by name at this point in the text-they become simply "He, she" (3). In introducing this pronoun identification at the beginning of the narrative, the novel displays another layer of language fluidity; in the text, "they"-a single, amorphous entity—can become instead two distinct persons. But more significantly, while the use of the gendered pronouns establishes a model for deconstructing racial and social limitations in South Africa, the novel draws attention to how gendered identifications expose the continued reconciliatory limitations across the country. ${ }^{209}$ While we might not be able to reconcile "he" and "she" in late-1990s South Africa where gender bias still looms large, we can use the terms to resolve other salient inequalities.

Throughout the first chapter of The House Gun, Gordimer continues to identify Harald and Claudia only as "he, she." In this way, the characters become tied to an idea of the universal; by pronoun reference, the characters could be anybody or everybody. Harald and Claudia become "everyman," so to speak. While the characters cannot break from distinctly gendered identities, they do help to link the social problems in South Africa to any we might encounter across the world. In other words, South Africa's injuries are everybody's. This idea is amplified when Gordimer references the global acts of violence to which the characters bear witness in the opening scene: "It is Bosnia or Somalia or the earthquake shaking a Japanese

\footnotetext{
${ }^{209}$ Gordimer speaks to gender and LGBT-related inequalities that have no national boundaries. She comments on these pervasive gender biases in The House Gun when Harald muses, "Of course. Women, only women, have this sort of resource. They think of how to ameliorate" (29, emphasis added).
} 
island between apocalyptic teeth like a dog" (3). As the "she, he" of the novel—Harald and Claudia - each represent a form of the global onlooker, the characters also stand in for the very specific and local persons immersed in the urban culture of violence in Johannesburg from where they watch the television set. ${ }^{210}$ Here, Gordimer enlivens the local/global elements of South African law, politics, and literature. The "terrible happening" in the novel could be anywhere on the earth, and its witnesses could be anyone: she, he. Yet at the same time, the setting is not Bosnia or Somalia or anywhere else; "something terrible" can occur anywhere, but the crime in The House Gun could not have occurred anywhere but Johannesburg.

In this early moment of the text, a description of the Lindgards' townhouse moves rapidly into a repetition of incomplete sentences that contain only the stark references to "he, she." Immediately following the description of their home and its fortified surroundings, a new paragraph begins: "He, she— - twitch of a smile, he got himself up with languor directed at her and went to lift the nearest receiver. Who, she half-heard him say, half-listening to the commentary following the images, Who" (3). Harald asks Claudia if she knows a certain friend of their son's, to which the novel itself replies: "He, she—-they didn't, either of them" (4). With this language, the reader must infer that "something terrible" here does not refer to a global event on television, but instead to an act of localized violence. Rather than describing the substance of the phone call, Harald sits down "without a word," and the novel again speaks to the silence between them: "He, she-whose turn" (4). Through omissions, we learn the crux of the "something terrible" while we also learn of its locality. The phone caller betrays "the obscene word" that "comes

\footnotetext{
${ }^{210}$ In a lecture given in Dakar in 1990, Gordimer highlighted the violence in South African cities and, indeed, throughout the country:

There is a lot of forgetting to do, in South Africa. Yet it should not begin before we face what we are in relation to what we wish to become. Progressive forces in our country are pledged to one of the extraordinary event in world social history: the complete reversal of everything that, for centuries, has ordered the lives of all our people, under all the successive governmental avatars of racism-conquest, colonialism, white republicanism - and has culminated, again and again, in violence.
} 
ashamedly from him. Murder" (4). And here, the "he, she" dynamic of the characters becomes disrupted. We learn that "both at the same instant were touched by a live voltage of alarm," and "everything has come to a stop" (4-5).

The local act of murder, distinct from the war crimes taking place in Bosnia or Somalia, is geographically situated through an image of Strelitzia leaves. The plants are native to South Africa and so named only in the region; elsewhere, we know them as "birds of paradise." Next, the novel zooms into Johannesburg, describing a divided city that resonates with a specific history of violence: "What is there to fear, defined in the known context ... in this city —a car crash, a street mugging, a violent break-in at the cottage .... What can be understood is a car crash, a street mugging, a violent break-in" (4-5). In Johannesburg, car crashes, street muggings, and violent break-ins are comprehensible. ${ }^{211}$ Next, the dual language of "he, she" shifts to become a divided phrase: "He/she. He strides over and switches off the television. And expels a breath" (5). The "He/she" of Harald and Claudia here alerts us that Gordimer is contending again with a different incarnation of the harmful forms of segregation that have come to define South Africa from a global perspective. ${ }^{212}$ She begins to reconcile the injurious separation of the backslash by turning the Lindgards into the "everyman" in Johannesburg; they are now immersed in the very violence to which people of their (race and) status have previously been exempt. The language suggests that, even when a social or racial position carries with it a promise of remaining outside the violence of the city, a literary description of that violence

\footnotetext{
${ }^{211}$ Gordimer said as much after she survived a violent break-in at her Parktown home. See The Guardian, "Nobel Laureate Nadine Gordimer Attacked," 30 October 2006, available at http://www.theguardian.com/books/2006/oct/30/nadinegordimer.

${ }^{212}$ Indeed, many countries maintained legislation like the United States' Comprehensive Anti-Apartheid Act of 1986, which imposed specific sanctions upon South Africa until the government agreed to end apartheid.
} 
reveals its universality. ${ }^{213}$

Since the novel brings to light the potential for language to upend certain hierarchical assumptions, it reframes the "grammatical fiction" term first introduced by Koestler in Darkness at Noon. But rather than attend to the recovery of bodily presence and self-consciousness, The House Gun excavates a collective human equality immersed in the fluidity of language; through language, Gordimer begins to repair the racial and cultural segregations established during apartheid. This work becomes salient in the relationship between Motsamai, Duncan's black defense attorney, and the Lindgards. After learning their son is accused of murder and has retained counsel, the novel introduces "the advocate Motsamai . . . Senior Counsel Hamilton Motsamai" (36). Upon his introduction, the Lindgards immediately acknowledge that the lawyer is a black man. The couple finds themselves "translating the private language of what is not being said: this Senior Counsel is black" (37). Initially, the novel introduces Motsamai by his Zulu surname (Motsamai), and only later by his title and Anglicized first name (Hamilton). While certain scholars read the relationship between Motsamai and the Lindgards as one that simply depicts a continuation of injurious racial hierarchies into the post-apartheid period, ${ }^{214} \mathrm{I}$ suggest that the relationship is more nuanced and can teach us how fictional narratives might invent new forms of reconciliation. Such an idea ultimately shows itself through a reworking of the grammatical fiction as Gordimer imagines it. Motsamai begins merely as a Zulu man to the Lindgards, questionably serving as Senior Counsel. However, the language of the novel gradually incorporates him into the same linguistic realm as Harald and Claudia.

\footnotetext{
${ }^{213}$ The language explains what the narrator says of Harald and Claudia: "Now they are in the category of those who buy themselves out of retribution because they can afford to put up bail and then retreat" (17). Here, Gordimer again plays with the us/them binary, referring to the Lindgards as "they" (17).

${ }^{214}$ See, for example, Natividad Martinez Marin, "Nadine Gordimer's Later Novels Or: The Fiction of Otherness" in Embracing the Other: Addressing Xenophobia in the New Literatures in English, ed. Dunja M. Mohr (Amsterdam: Rodopoi, 2008).
} 
This process of reconciliation begins at the Lindgards' first meeting with Motsamai. When speaking to Harald and Claudia, Motsamai's pronoun references become confused. He searches for language to explain how his legal argument will seek to frontload mitigation at Duncan's trial. He says, "What I am asking you to understand is that I-we- the attorney and I-have to prepare our argument for such a contingency" (42). Motsamai continues to fumble with his pronoun usage. To the Lindgards' questions, Motsamai responds with phrases like, "I fully appreciate, I fully understand, the advocate repeated in different formulations, developing what lawyers call their arguments. Ah-hêh" (42). Whereas the use of the "I" in Darkness at Noon signified a reclamation of self-consciousness, in The House Gun this pronoun seems at first only to differentiate Motsamai-he identifies himself as separate from Duncan, the Lindgards, and other members of Duncan's counsel. Indeed, he exhibits discomfort as he struggles to assert himself against the white, upper-class characters that populate the novel.

Yet after Motsamai's botched attempts to identify himself in relation to Harald and Claudia, the novel's third-person narration reconciles his position to the Lindgards. Like the gendered pronouns that move Harald and Claudia into a realm of identity equality, Gordimer's narration does the same for Motsamai. Shifting from his first-person dialogue to an objective third-person commentary, Gordimer's narrator refers sharply to Motsamai as "He" for the first time in the text. In form, the novel begins to create an equality among Motsamai and the Lindgards, while in content it continues to allude to a fracture between them. Emphasizing that Duncan should tell the truth, Motsamai says, "The warder would be most unlikely to comprehend anything you talk about, anyway. Most of those chaps are still a hangover from the old days. Sheltered employment for retarded sons of the Boere. - He tosses an indiscretion he knows won't go amiss with these people. - Our government finds you can't change the prison 
system overnight - or many nights. Ah-hêh._-" (43, my emphasis). Here, the novel links Motsamai to Harald as "He," but also to the Lindgards generally as "He/she." Motsamai also uses the language of "our government," which solidifies this connection. His previously italicized "foreign" utterance of "Ah-hêh" also becomes conspicuously normalized.

Gordimer emphasizes the significance of language she has chosen here, as the novel quickly turns to a private discussion between Harald and Claudia. As if to mirror the reference to Motsamai as "He," the novel includes a stand-alone sentence: "She and he" (44). The couple sits in a room with Motsamai, and up until this moment, they have appeared as separate and distinct. Upon closer inspection in this scene, however, we realize that "she and he" might refer here to Claudia and Motsamai; the text remains strategically ambiguous and urges the reader to recognize the grammatical fiction of racial segregation. In other words, the language displays the interchangeability of the pronouns, as the characters' roles might be more fluid than we might originally have imagined.

Through the rest of the novel, Gordimer refers increasingly to Motsamai as "He," mimicking the language through which she introduced us to the Lindgards. In so doing, the novel emphasizes the ability of language to reveal linguistic equalities in the face of lingering questions of social and racial inequalities. Even if the fractures of racial segregation remain visible in free South Africa, Gordimer begins to break them down through language by exposing the injurious fiction that has created them.

In a conversation among Claudia, Harald, and Motsamai at a later moment in The House Gun, the dialogue goes so far as to refuse to identify to whom it refers. Motsamai asks the Lindgards simply if they have seen their son, Duncan. What follows is a muddling of narration and dialogue in which the three characters discuss Duncan's position at his architecture firm: 
She may not know, but he, impatient, does: why pretend! - He's determined to finish the plan he was working on, you've arranged that, I gather. I don't know what the firm will feel about it.-

-Oh, he's still on the payroll. Man! I should damn well hope so! They'd look fine if they struck him off before he faces a charge that hasn't been heard. I would not be prepared to let that pass, you can be sure.-

- If the man himself does not wait to be judged guilty.- (111).

While the text pretends to have Duncan as its subject here, the reader's focus instead becomes a question. Who is speaking, and to whom does the text refer? The grammatical fiction of "he, she" shows itself plainly as it becomes impossible to identify the speaker of the dialogue. The "he" might refer to any of the (male) characters, including Motsamai, Harald, and Duncan.

Given the inability to distinguish among them, Gordimer first suggests an equality of language among the Lindgards and Motsamai. But she also introduces the gray areas and variability between victim and perpetrator, for here, Duncan might easily be mistaken for his father or for Motsamai. And indeed, exposing the fictional binary of perpetrator/victim is of particular political importance in free South Africa and for the aims of the TRC, as black, coloured, and white South African perpetrators sought amnesty through the proceedings; in other words, the TRC was not divided along racial boundaries of black victims and white perpetrators. $^{215}$

Gordimer elaborates upon the fluid binary of perpetrator/victim by linking it to the racial ones she has already exposed. Specifically, she suggests that the Lindgards have switched roles with the parents of apartheid-era killers; the novel describes Harald's sentiments as he sits in the Makwanyane courtroom: "The only people with whom he would have common cause would be the parents of whoever Themba Makwanyane and Mvuso Mchunu might be" (138). Harald becomes, for all intents and purposes, the black parent of a black perpetrator. Gordimer

\footnotetext{
${ }^{215}$ See Boraine for a detailed discussion of how there were a small number of cases of black South Africans who had committed murder on racial grounds and fell within the purview of the TRC's amnesty provision.
} 
underlines the inequality that still exists between the Lindgards and black South Africans as Harald muses that "it was unlikely these parents would be among the crowd in the court, almost certainly they are poor and illiterate, afraid to think of exposing themselves to authority in a process incomprehensible any other way than as whether or not a son was going to be hanged one daybreak in Pretoria" (139). Despite his socio-racial identity, Duncan has become like the violent criminals prosecuted in the South Gauteng High Court and sentenced to death through a system of racial prejudice. Ironically, Gordimer tells us, the apartheid system of segregation that produced black "criminals" resulted in a climate of violence in which the terms of perpetrator and victim do not fall along racial lines.

Yet the language of The House Gun also emphasizes a reconciliatory potential between perpetrator and victim in the new South Africa. Echoing the TRC mantra that everyone is both an apartheid victim and a perpetrator regardless of race, the novel decries, "Prison, it was allperpetrator and jailer, perpetrator turned victim of jailer, son become betrayer of the love parents had given him, parents become betrayers of the covenant made with him" (129). To be sure, Themba Makwanyane becomes unidentifiable not only as a criminal, but also as yet another "he" who exists in the space of the courtroom, like Motsamai, Harald, or Duncan: "He is not contesting his guilt," the novel tells us. Rather, "[h]e is contesting the right of the State to murder him, in turn" (132). Suddenly, Harald too becomes enmeshed in questions of guilt, as "[h]e comes, as if to a clandestine rendez-vous, to the old Fever Hospital" to hear the Makwanyane case (132). Harald and Themba Makwanyane are both victims and prisoners in this moment; literally, both suffer injuries induced by the apartheid regime, while both also become perpetrators. Themba Makwanyane committed murder, and Harald remained a bystander of the authoritarian regime up through the period of transition. Gordimer reminds us 
of Harald's starkly neutral stance during the apartheid years:

The Lindgards were not racist, if racist means having revulsion against skin a different colour, believing or wanting to believe that anyone who is not your own colour or religion or nationality is intellectually and morally inferior . . . . Yet neither had joined movements, protested, marched in open display, spoken out in defence of these convictions. They thought of themselves as simply not that kind of person; as if it were a matter of immutable determination, such as one's blood group, and not failed courage. He did not risk his position in the corporate establishment (86).

Here in the courtroom of the novel, language renders the two men as equals.

Gordimer solidifies the idea that language can invent new forms of equality at the end of The House Gun, where she returns to the repetition of the binary phrase "he/she." As earlier in the novel, the backslash between the pronouns suggests a singularity of unit in its shift from "he, she," or perhaps an ameliorative idea of being "in the family," as Gordimer writes (288). Indeed, by the end of the novel, the family unit to which the pronouns refer is not only the Lindgards and their son. By the close of The House Gun, "he/she" also contains Motsamai and Khulu. The "he/she" unit becomes a tool for reconciliation at this moment in the text. The language opens up the possibility of "Motsamai, playing father when father cannot" (243). Soon thereafter, the novel moves to a scene in which Khulu visits the Lindgards with news from Motsamai (243, 288). Sitting around a table, Khulu and the Lindgards speak of Motsamai's presence and imagine Duncan's. In this moment, "no-one speaks, and then Khulu takes a mouthful of beer ... . He/she" (288). The novel formally reimagines the he/she binary as a familial unit that contains the Lindgards, Khulu, Motsamai, and all other characters brought to mind through the scene. As such, Gordimer subverts the pronoun binary to the point at which its unequal foundations, or suggestion of a stark divide between two persons - carries no meaning. Instead, only the relationships among the characters, regardless of race, class, and sexual orientation, hold significance. 
The novel comes full circle on its last page, wherein Gordimer describes lingering issues of criminality simply as "a matter between them" (290). The unidentified pronoun reference alludes to new distinctions between the characters in the novel and to us as readers. In so doing, it solidifies the fictionality of the us/them binary and the ability for imaginative narrative to break it down; someone like Khulu—one of "them" in an apartheid-era racialized binary scheme - has become indistinguishable from the Lindgards. Through the fluidity of the pronoun, the text reveals the equality of the characters as it underscores the grammatical fictions we use for the identification, sorting, and classing of persons. Indeed, Gordimer restores the power of language as she exposes its falsehoods. In The House Gun, grammar underlies interpersonal reconciliation despite lingering socio-racial divides in the free South Africa.

This linguistic healing extends to the physical spaces of urban South Africa, where injurious fractures remain salient in the landscape. Gordimer's interest in recovery is not limited to the metaphysical potential of her literary courtroom or the domestic realm inhabited by her characters. Intent to locate even abstract concerns within embodied social life, Gordimer turns to the practices of urban culture and private space. She makes a decisive shift to the physical materialization of retributive and restorative justice in relation to Johannesburg, a city that is perhaps most widely acquainted with the injuries of apartheid. Extending the spatial dialectics of her earlier novels, she maps injurious fractures onto the landscape of the city. The ruptures in metropolitan space represent the localized consequences of apartheid, but they also implicate lingering wounds of institutionalized racism that echo globally.

\section{Geographies of Violence and Spatial Reconciliation in Johannesburg}

"The geography of crime is a geography of vulnerability. In Greater Johannesburg, it is 
drawing to the surface new dimensions of apartheid's mapping of the city and adding further dimensions to its social and spatial divisions" (Bremner). As early as the 1950s, Gordimer herself described the city as an urban space that "seems to have no genre of its own,",216 and contemporary South African artist William Kentridge has described Johannesburg in terms of the dichotomy between "very leafy suburbs that are manmade" and a "very bleak landscape around it, complete fiction." Loren Kruger has also discussed the "unimaginable as well as unmanageable" reputation of Johannesburg, and argues that recent cinema can provide us with new images through which to conceive of "becoming and belonging" in the urban metropolis (Kruger 141, 155).

Indeed, spatial divides have turned Johannesburg over the last half of the twentieth century into "a kind of desperate town," according to Kentridge:

It is always a city that was felt abnormal in the sense that there was this a huge separation. Black people largely living in Soweto on one side and a circle of white suburbs around the city center with odd pockets of black people living in Alexandra township and a huge gulf between a very brutal city center and an extraordinarily generous leafy are where the middle class live and life is spent."

One of the few cities in the world with "no geographical reason for its existence" - only tons of gold below its surface - Johannesburg actually was erected in terms of a divided thinking: build a city to reach underneath it. A separation of people followed.

If The House Gun can use language to reconcile certain social and racial binaries produced by apartheid, can it also imagine a way to heal the nation's spatial fractures? The architectural and metaphysical elements of space come to play a large role in matters of violence and reparation at work in The House Gun. By attending to the stark divides between public and private spaces, as well as the more injurious segregated ones, the novel considers the language of "remedy" and "healing" to envisage reconciliation.

${ }^{216}$ Gordimer, World of Strangers, 80. 
Gordimer has long been interested in connections between the public and private spaces of the South African city, and the ways in which apartheid policies made visual the "power of space to separate individuals from one another" (Barnard 6). Rita Barnard's recent work in Apartheid and Beyond: South African Writers and the Politics of Place argues that there has always been a "spatial dimension of Gordimer's political thinking," which shows itself aesthetically through the oppressiveness of the city space (10). Gordimer's early work during the years of apartheid demonstrates that the street is "the site where history 'takes place,"” since it is free from the surrounding legally segregated spaces (10). During apartheid especially, it could be liberating to imagine the streets as utopian areas. Yet, as Barnard explains, despite the eradication of de jure segregation with the dismantling of apartheid, "even the streets of the new South African city have developed ... in ways that impede the ideal of a polyglot site of bodily closeness and chance encounter" (67). Given that Johannesburg remains in many ways a private city, owned by big businesses and segregated de facto due to the economic inequalities that linger from apartheid policies, its streets still betray elements of the past. Barnard eloquently clarifies how "it can be increasingly difficult to find evidence that the old geographies of division have been erased" since "the old divisions are not articulated and justified in new terms" (67).

Mapping Johannesburg from apartheid into the transitory period requires us to trace various histories of violence that have scarred the city. ${ }^{217}$ The legal separation of races during apartheid in both interior and certain exterior spaces "clearly represents an extreme and therefore starkly illuminating instance of the territorialization of power" (Barnard 5). Yet political violence as power is not the only struggle that underlies Johannesburg's streets. In many ways, the city is a palimpsest; violence, perpetrated both in the name of apartheid policies and as reconciliatory measures, have led to re-routings and frequent official name changes throughout

${ }^{217}$ For a discussion of the postcolonial mapping of modernity in Nairobi, see Slaughter, "Master Plans." 
the urban area. A labyrinthine place erected through different forms of violence to the land and people, Johannesburg has seen its streets names written and rewritten between 1948 (with the institution of apartheid) until present. The country, in fact, has witnessed the destruction of entire urban communities, only to see them reconstructed or rewritten in the years after the apartheid system was dismantled. ${ }^{218}$

Even such alterations intended to remedy apartheid-era wrongs have added to the impenetrability of South Africa's city spaces. ${ }^{219}$ Indeed, we might view a place like Johannesburg as palimpsest of power: "successive strategies to exert control over the population, overlaid on the geography of the region, where the dominant features are the east-west mining belt, layers of parallel ridges, and an arc of unstable, dolomitic land, have resulted in a fragmented, spatially discontinuous city" (Bremner). Alternately, "extreme forms of violence" were justified by anti-apartheid activists before the early 1990s "as weapons of struggle, both within the formal institutions of the state and beyond them, and not considered criminal by their perpetrators" (Bremner).

Notably, the violence associated with Johannesburg in its early post-apartheid years also undermines spatial reconciliation. It drives de facto segregation, thereby revealing the stark inequalities that remain throughout the city. Johannesburg "has become a field of violent contestation between extreme wealth and extreme poverty, between luxury and subsistence, idyll and inferno, excess and need" (Bremner). In an address given at Stanford Law School in 1996, Helen Suzman, an anti-apartheid activist and politician, spoke of urban South African cities when she said, "We are still faced with an enormous upsurge in crime and violence, and this, unfortunately, is reflected daily in the press by alarming stories of armed robbery, murders, rapes

\footnotetext{
${ }^{218}$ See Hallett for a discussion of District Six in Cape Town.

${ }^{219}$ For example, consider the OR Tambo Airport and the renaming of Pretoria; these name changes have rendered traditional ways of understanding geography and negotiating urban spaces irrelevant.
} 
and car hijackings. All this is one of the major causes of the brain drain of white people with expertise" (Suzman 156). Gordimer acknowledges this kind of description of the city as she situates The House Gun in Johannesburg by simply depicting stark images of crime.

Criminality becomes salient in the political, literary, and even architectural work within the country. Lindsay Bremner is a prominent South African architect who played a significant role in determining spatial redress through post-apartheid city planning. Specifically, she worked on the Baralink project linking Johannesburg and Soweto, and she helped to design remedial spaces like the new Constitutional Court. Bremner described Johannesburg first and foremost as "a city shaped by segregation" (Bremner). Beginning with the country's long history of exclusion and racial violence, Bremner explains that the city remains segregated even today, although now by a kind of violence endemic to the transition period. "During the apartheid years," she explains, "crime in Johannesburg, and indeed in most of South Africa, was confined largely to black townships" (Bremner). Indeed, wealthy urban areas of South Africa had been "immunized against crime by the state security system," Bremner explains, invoking language of medicinal remedy and public health. Even at the height of anti-apartheid violence on both sides, uprisings and crime remained largely confined to the townships. Naturally, racist state security forces sought to quell "politically inspired violence" in kind, with their own crimes adding to climbing statistics of rape and murder in South Africa. In the transition period, however, the fragmented spaces of the city began opening up to liminal regions of violence. Bremner refers to "the space between things falling apart and things being put together is this highly charged, criminalized one.” The post-apartheid violence to which Johannesburg has been subject is now layered upon its past. "Having its roots in the old social economy of apartheid," Bremner explains, "it is an intense network of violations, attacks, counter-attacks, incisions and 
moneuvres." Here, "new divisions between victim and criminal, fear and bravado, vulnerability and immunity are cross-crossing the old ones of race, class and gender in the creation of Johannesburg's new economic, social and spatial order” (Bremner).

A prominent spatial binary has arisen in recent years from the city's forced segregation under apartheid. Relying on incidents of endemic violence to explain the de facto divides in contemporary Johannesburg, Bremner paints a picture of the city in which the terminology of here/there is underlain with a traumatic history. When we think about being "here" or "there" in Johannesburg, we are forced into the fictional lines drawn throughout the urban space-first in the city's subjection to the deleterious practices of gold mining at the turn of the century, and subsequently through the National Party's institution of apartheid. Much like the fictionality of human identity that Gordimer exposes through her unique use of the pronoun, the divides in Johannesburg too are "complete fiction," as Kentridge contended. If The House Gun envisions individual reconciliation through play with grammar, how does it conceive of healing the physical violence endemic to South African urban space?

In view of Gordimer's attention to spatial politics and the architectural coding embedded in The House Gun, the novel not only questions the broad judicial mechanisms for violence, but it also seeks extra-legal recovery linked specifically to the city space. Couched in the same therapeutic terms of public health and wellness that Bremner uses to describe the spatial divisions of Johannesburg, Gordimer imagines the city as a site that is deeply ailing in the postapartheid years. Without this illness afflicting it, the crime passionel in the novel may never have occurred. Duncan and his housemates only kept the house gun around as a commonplace object, "like a housecat," because of the looming threat of violent crime (Gordimer 43). As such, The House Gun conceives the ongoing violence in the city as a sickness connected to its 
transition from apartheid. But can a medicinal remedy heal what ails Johannesburg and other urban spaces in South Africa? Gordimer poses this question through Claudia's impulses as a physician. Connected directly to her son's crime, Claudia laments that she cannot simply prescribe a pill for Duncan (31). Yet, can medicinal conceptions of remedy provide a framework through which to repair the city? Offered as a potential antidote to the limitations of legal justice, Gordimer asks us to envision a multiplicitous notion of remedy that requires a turn to imaginative literature to move beyond the boundaries of the legal.

To talk about restorative justice, we must always ask about models of remedy. Its very definition is tied inextricably to both legal and medicinal modes of redress. The OED defines the word as "a means of counteracting a source of misery or difficulty," a denotation that might easily fit both conceptual and bodily healing. A second definition finds remedy as "a cure for disease, disorder, injury, etc.; a medicine or treatment that promotes healing or alleviates symptoms." Notably, functions of law and medicine deeply entwine in this definition; it alludes primarily to bodily injury but also invokes a legal one. A third definition saliently addresses the juridical denotation, defining remedy as "a means of legal redress." Notably, Alex Boraine, one of the primary "architects" of the TRC, has framed the commission in terms of "healing the divisions of the past" (349). Such a connection between forms of remedy is not a new one; the South African media prominently used medicinal language to conceive of political repair during the transitional period. A cartoon printed in a December 1995 issue of The Sowetan, an Englishlanguage newspaper headquartered in Johannesburg, tackled the question of corporeal healing with regard to the TRC. Depicting a larger-than-life wounded body with a rag across the forehead reading, "SA" (defining the body as the country), Desmond Tutu and Boraine appear alongside dressed as surgeons. A medical lamp hangs above their heads, printed with the words 
"Truth Commission." A speech bubble from Tutu reads, "We have to open up those festering wounds to cleanse them—it'll hurt, but you'll feel much better afterwards!” Indeed, Albie Sachs has emphasized that "the idea of healing the wounds of the past" is a concept always framed "in terms of restorative justice" (Sachs 439).

Gordimer questions the possibilities for restoration, drawing out a dual medicinal and juridical "remedy" in The House Gun. In so doing, she emphasizes the healing potential of legal justice when it is reconceptualized through fiction. Intertwined deeply with the question of capital punishment in South Africa, The House Gun specifically links medicinal remedy to the Constitutional Court's eradication of the death penalty in Makwanyane, a case I discussed previously. In the Court, “[h]ealth not sickness, life not death is the venue," Gordimer's novel tells us (132). This language ties back to Gordimer's suggestion that the court system can offer a model of reconciliatory justice. But more significant to healing the spatial wounds of urban South Africa, the novel frames Johannesburg much like the festering body in The Sowetan, crying out for repair.

If Johannesburg is wounded, who can deliver a remedy? The novel introduces us to Claudia through her role as a repairer of human malady. Invoking the legal idea that remedies make victims whole, the novel describes Claudia accordingly: "She's a doctor, she sees what the ambulances bring in to Intensive Care. If something's broken she can gauge whether it ever can be put together again" (4). Indeed, "the irreparable made her reckless" (81). As such, Claudia "worked at clinics to staunch the wounds racism gashed" (86). The connections between law and medicine emerge in a judicial context as the novel progresses, revealing that a criminal "confession of guilt" can in fact be understood as "a diagnosis" (61). Considering Duncan's chances at trial with Motsamai as his lawyer, the novel asks us, "Was the patient absolutely 
satisfied with the competence of the one in charge of his case, was he sufficiently impressed with Motsamai ...?" (62).

The House Gun's attention to medicinal repair connects directly to the spatial violence of the city. Stricken with the ills of crime, Johannesburg suffers from a fevered condition. In view of Duncan's offense, we are left to ask of Claudia, "What could she prescribe for this kind of fever" (62). The word "fever" itself can be used to detail both medical and social afflications; simply put, it is "a morbid condition of the system" (OED). If the murder in the novel is incident to a larger disease affecting Johannesburg, can legal justice for a single crime provide a remedy? The city is suffering, The House Gun tells us. "The random violence of night streets" and the "daily tally of deaths" mars the urban space $(11,49)$. Can we expect the city to recover, or can we only seek an analgesic?

Criminality is so immersed in the urban space that is becomes "a labyrinth of violence not counter to the city but a form of communication within the city itself" (141). Are we able to map a city through its violence? Bremner's architectural work suggests we can. In seeking to visualize the regions of Johannesburg afflicted by various types of violent crime, Bremner provides images of four distinct maps that highlight areas of the city according to the rate of crime in each. The neighborhoods closest to the industrial center are darkened to show the highest rates of rape and murder, while maps depicting motor vehicle theft and hijacking portray blackened areas in the northern, affluent suburbs.

Even if we are able to visualize the geographic violence of the city, can the novel depict how corporeal and political sickness interrelate in social space? Claudia's medical work deals "with disease, and the damage other people caused" (87). Yet in this language, the novel implies legal harm-legal remedies exist precisely to repair inasmuch as possible the damages that other 
people cause. Yet at the same time, Claudia's healing work also alludes to a disease that is spatial at its roots. For, as the novel tells us, it is "other people, who tear-gassed and set dogs upon blacks, evicted people from their homes to live in shacks from which old men and women were brought to her dying of pneumonia and children were brought to her dwarfed by malnutrition" (87). Indeed, the plight of urban South Africa becomes a proximate cause for public health concerns.

And likewise, the sickness of the city has led to the murder in The House Gun. In a city mapped by violence, where "a reading of its varying density could be taken if a device like that which measures air pollution were to register this daily," Duncan has become ill (141). He is "contained in that labyrinth along with the men who robbed and knifed a man and flung his body from a sixth-floor window" (141). Like a virus, the violence is "an aberration passed on by those in whom it mutated out of suffering, but because violence is the common hell of all who are associated with it" (143). He lives in a society, Gordimer writes, where "the moral taboos against violence are devalued," and there may even be "the unconscious sanction of violence" (226-27). Surrounded by the city's sickness, "it becomes clear to those who witness a trial that there is no such act as the simple act of murder. To kill is only the definitive act arising out of many others surrounding it, acts of spilled words, presumptions, sexual congress, and all around these, muggings in the streets" (247). Some of Johannesburg's residents may be so immersed in its maladies that they come to internalize them. Some of Claudia's patients, notably, "did not have words, in English, to express what they felt disordered within them" (12). Indeed, Motsamai uses the violence afflicting the city as a mitigating factor in Duncan's trial: “The climate of violence bears some serious responsibility for the act the accused committed, yes; because of this climate, the gun was there. The gun was lying around in the living-room, like a 
house car; on a table, like an ashtray" (271).

If post-apartheid South African urban space suffers from the sickness of violence, what can a remedy look like? The "secular humanism" that Claudia practices - "to do good and care for others by healing the sick"-is presented as one of the only methods to quell spatial harm. It is what "the whole world relies on ... to keep at bay our instinct to violence, to plant bombs, to set ablaze, to force the will of one against the other in all kinds of rape ... to take up a gun and shoot a friend, a housemate, in the head" (98). While medicine makes for a compelling metaphor in the pursuit of urban reconciliation, the novel also suggests that both medicinal and judicial restoration are closely intertwined as it binds acts of diagnosis and seeking justice. As if detecting an illness, Motsamai “has his ways of getting out of people what they don't know they're revealing" (118). Indeed, Gordimer explains, "it's like the gift for diagnosis some doctors have" (118).

Motsamai can aptly identify the illness afflicting the city and the judicial mechanisms needed to combat it. In turn, the novel comes to define restoration through the relationship between medicine and the post-apartheid judicial system. It further elucidates this definition, describing the seat of the South African Constitutional Court as the site that "will house the antithesis of the confusion and disorientation of the fevered mind" (132). Returning to ideas of the fevered city and medicinal analgesics for its illness, The House Gun implies that a remedy may lie in the reformulated court system. At the very least, juridical mechanisms for remedy no longer are impediments to a restorative justice as they were during apartheid; the two need not be mutually exclusive. To be sure, "prison is not a disease, there's nothing infectious to keep clear of" (164).

The novel interweaves questions of restoration and reparation as it considers the 
physicality of the city's pain. Whose role is it to restore the human body and to repair sites of violence? Is medicinal or juridical attention required? In The House Gun, Gordimer distinguishes between the two through the dialectic of inside/outside. Turning again to the process of reconciling two disparate entities, we can tie the novel's work back to our earlier discussion of the social, legal, and historical binaries in South Africa. Returning to themes of private and public spaces explored earlier in her career, Gordimer seeks to pinpoint precise locations of injury. "There is plenty of pain that arises from within," the novel tells us, "this woman with a tumour growing in her neck, plain to feel it under experienced fingers, and then the usual weekly procession of pensioners hobbled by arthritis" (13). But pain that can be medically diagnosed is distinct from the socio-spatial injury inflicted upon Johannesburg. Indeed, there is "pain that comes from without - the violation of the flesh, a child is burned by an overturned pot of boiling water, or a knife is thrust" (13). What can repair this kind of wound? It is at once bodily, but it is also deeply ingrained in notions of judicial remedy:

A bullet. This piercing of the flesh, the force, ram of a bullet deep into it, steel alloy that breaks bone as if shattering a teacup - she is not a surgeon but in this violent city she has watched those nuggets delved for and prised out on operating tables, they retain the streamline shape of velocity itself, there is no element in the human body that can withstand, even dent, a bullet - those who survive recall pain differently but all accounts agree: an assault (13).

The physical wounds inflicted by the violence epidemic in Johannesburg can be mended on an individual level through medical attention, but in the end, the appropriate language to define those wounds remains open only to legal treatment; at its core, the violence isn't just bodily injury, but is an assault.

If these acts against the body might be remedied literally through medical attention, is the novel accurate when it informs us that "the purpose of a doctor's life is to defend the body against the violence of pain" (13)? Contending with the larger context of the criminal city space, 
legal justice might function as medicine for the wounds of state policies of racism. Ultimately, the novel implies that neither medicinal cures nor legal remedies are sufficient to ensure a sociospatial reconciliation of Johannesburg and the people dwelling within it, as there are no largescale remedies to induce immediate healing. And worse, the novel suggests that "violence is a repetition we don't seem able to break" (294). Yet our previous reading of South African legislation can prove useful here. Despite the incompleteness of its imagined remedy, the novel's invention of new ways to discuss the condition of Johannesburg and the possibilities for its reconciliation lays a foundation from which to consider distinct forms of narrative restoration.

During apartheid, the city was like a prison. Due to the segregated public spaces and the exclusionary pass laws, ${ }^{220}$ non-white citizens began to see the inhabitable spaces in their city as jail cells (Enwezor 36). Indeed, the pass laws "confined millions of subjects to spaces of literal incarceration" (36). Describing the difficult work of non-white photographers working in 1980s Johannesburg, Okwui Enwezor explains that "the same laws that limited the movements of blacks and blocked access to social amenities only available to whites, also restricted the range of what a street photographer could hope to document beyond the legal boundaries of his confinement" (36). Urban streets imprisoned South Africans, starkly restricting movement. Indeed, this is the very confinement that Gordimer seeks to dismantle through her fluid use of the pronoun, as I discussed previously. Enwezor's essay considers how artists who disregarded the exclusionary laws instituted prison breaks, finding ways to live in the liminal spaces of the city. ${ }^{221}$ The House Gun acknowledges this view of Johannesburg under apartheid, and further explains that "to be in prison is to be dead to connection with consciousness outside, to exist

\footnotetext{
${ }^{220}$ Pass laws prohibited the travel of black South Africans beyond certain parts of the urban spaces and the country generally. Non-white citizens were required to always carry their pass books, even when stepping outside of their homes. If they were caught without a pass book, they would be arrested. See Mzansi Magic, Liliesleaf (documentary), August 2013.

${ }^{221}$ See, for example, Santu Mofokeng, House of Bondage.
} 
there only in the past tense" (25). Yet, the novel revitalizes the cell and thus its urban connection. Whereas once the city and cell destroyed existence through severely limited movement, both Johannesburg and the prison cell develop reparative potential for Duncan. The de jure free movement through the city after apartheid engenders a new conversation about the prison space. Is it still trapped in a stifling past, or is rehabilitation possible within it?

Urban space soothes Duncan: "The architecture of ancient Greece-yes, of course" (293). Using the language of architecture to inform juridical repair seems apt, for the people who create legal mechanisms, particularly in connection with the TRC, often are referred to as "architects." But is the spatial sickness that threatens post-apartheid Johannesburg so ingrained that it is impervious to a remedy of any kind, or does the city already contain a foundation for its own healing? The novel cannot cure the city of its deep-rooted history of violence. Addressing commonplace conversations about the transitional period, Helen Suzman explains that "a popular phrase in South Africa" is "the legacy of Apartheid" (Suzman 156). However, Suzman herself doesn't like to use the phrase because, as she says, "a legacy is usually very nice." Instead, she clarifies how she "talk[s] of the ravages of apartheid, for ravages they certainly were, and it will take many years to eliminate them." Yet, like medicine, new forms of justice may be able to act as palliatives.

The House Gun alludes to this in a penultimate scene describing Duncan's continued work as an architect while he remains imprisoned. Duncan considers that, while he cannot remember the precise moment of his crime, he has had to reconstruct it from the pieces, and in those fragments he has found a kind of serenity (293). Here, Duncan's mode of repair speaks to that illuminated in the previous chapter by Hemon's The Question of Bruno, as destructed fragments come together to produce a new kind of whole. Working on a microlevel, Duncan 
finds this rehabilitation within the space of the prison cell:

Motsamai made sure that the firm sent Duncan sections of their projects to design. He never saw the completed set of plans for which he was drawing vertical, horizontal and lateral projections, aspects from the North and South, East and West. But he thought sometimes how his own work was already achieved; the structure of this cell was his accomplishment, designed to the specifications of his life (286).

With Duncan finding peace in the imprisoning walls of the jail, the novel in some ways reconciles the prison-like space of Johannesburg during apartheid; now, for Duncan, the isolated space of his cell enables recuperation. Within those walls, a prisoner can look forward. In fact, the emphasis on a larger set of architectural plans, for which Duncan only has access to create sections, acts as a metaphor for the city. It allows us to think through dialectics of global and local, collective and individual. If we view Duncan's crime as part of a larger social problem rooted in more than fifty years of apartheid, must we view the remedy on such a large scale? The novel's treatment of architecture implies that the rehabilitation actually may lie on a smaller, more manageable scale. Through individualized acts of repair, the city can find itself slowly treated for its disease of violence. Yet the question remains: in the immediate future, can remedies offer only mollifying terms? These issues reflect heavily upon the limitations of the TRC, and the distinction often elucidated by truth commission critics between laying the foundations for reconciliation and enacting it.

At first, Claudia's actions represent these remedial limitations. While awaiting both the verdict in Duncan's trial and the Makwanyane outcome, "Claudia prescribed a sleeping pill for herself and went to bed" (239). As if acknowledging that she cannot treat what ails her, she chooses a soporific drug to induce sleep. Considering the violence of the city and its stifling sickness, Harald and Claudia wonder if they need to leave Johannesburg in order to find peace:

She tried to think of this in practical terms: perhaps they should leave the townhouse complex as it really was already, void of their life there. Perhaps they should move 
house. Could any team of professionals with their packing cases and vans make such a move; and wouldn't it all, the stored possession that were Duncan's from that cottage along with everything else, be delivered, unloaded, surround Harald and her in the next habitation? (285-86).

Claudia's internal musings suggest that violence is omnipresent, and that down to the smallest detail, their lives have been scarred by life in urban South Africa. Yet after the trials end, the couple makes a conscious choice to remain in their Johannesburg townhouse (287). Given their willingness to submit to the potential for reconciliation in the city, the decision to remain in Johannesburg produces restorative power within their own marriage and in their intercultural relationship with Khulu.

The violence of the city, for all the harm it has engendered, thus carries the possibility of new reconciliations, even if the novel depicts them as largely within the private sphere. In their Johannesburg townhouse, a visit from Khulu confirms a relationship between the three characters that would not have been possible prior to Duncan's crime. When Khulu finally leaves the townhouse, "they part that night with the intimacy of court days restored" (290). In fact, upon their parting, "Khulu Dladla has his own knowledge that this couple to whom the fact that he's black and gay doesn't preclude his being, to them, like a son” (290). Harald and Claudia's marriage also undergoes an intimate recovery. Whereas the two once suffered from blatant marital problems, the trial and its outcome teaches the couple that, for their own relationship and for their relationship with the "Other" in free South Africa, "they have the remedy in themselves" (14).

Links between the juridical and the medicinal can help to show where remedies are possible. If remedy can lie in individual restoration, can it also occur through remakings of the law within the public sphere? Returning to the notion that the Constitutional Court can heal the "fevered mind" (132), the Court's holding in Makwanyane provides Claudia with the courage to 
remain in Johannesburg and to start anew, "in spite of everything" (285). On the last pages of the novel, the narration emphasizes that

The Last Judgment of the Constitutional Court has declared the Death Penalty unconstitutional. The firm and gentle tone of the Judge President has the confidence of a man who while he is conveying the ruling arrived at after several months of weighing scrupulously the findings of a bench of independent thinkers, himself has been given grace. There is serenity in justice (284).

The double entendre of the remedy is twofold. On the one hand, the Court rules in favor of rehabilitation for perpetrators of violent crime, endowing its decision with a Christian benevolence that closely mirrors the Ubuntu practices of the TRC. ${ }^{222}$ On the other hand, the members of the Court use their holding as an analgesic. The judgment acts as a legal remedy for the transitional violence in Johannesburg. While the Court cannot abandon principles of proportionality to ensure that the punishment fits the crime, it can rename "justice" as something that lies outside the bounds of retribution. The "justice" of the decision attends more closely to the principles of reconciliation offered by the commission, holding out the potential of criminal rehabilitation. For Claudia, the news "sets her visibly trembling," and in that physical response she finds "release, relief, a curious trace, like happiness" (284).

The novel helps us to consider the distinct restorative potentials for South Africa within imaginative literature. Given the chapter's focus on reconciling deep fractures within the country, this analysis would not be complete without a turn to a more ameliorative divide: the local/global dialectic that has come to define jurisprudence in the free South Africa. ${ }^{223}$ Two-way shifts between domestic and international components effect a reconciliation of the seemingly distinct entities. The global informs the local, establishing South African law in terms of

\footnotetext{
${ }^{222}$ In South Africa, it might be natural for the Court to invoke a religiously inflected form of reconciliation. After all, the Constitution and Unity Act stressed the important of religious forgiveness and Ubuntu. For further reading, see Braine 360.

${ }^{223}$ This binary takes other forms that aren't has ameliorative, such as Balibar and Wallerstein's conception of the center/periphery model. But here, as I will show, the dialectic becomes reconciliatory.
} 
international human rights norms. Given the close relationship between domestic policy and the humanistic aims of human rights law in free South Africa, the country's juridical apparatus moves it from a politically and geographically isolated position to a far-reaching one.

\section{The Local/The Global: South African Jurisprudence and International Law}

Gordimer's novel presents an opportunity to move from an analysis of the postcolonial to the global. Literary trends depict this shift, ${ }^{224}$ and my reading of The House Gun alongside South African legislative texts can help us to break down the binaries traditionally conceived in the local/global dynamic. The Constitution and subsequent legislation have strong roots in international law. The local and global come together to provide a methodology through which South Africa can attend to its history and create a bridge to its future.

Commenting on the work of the former South African Justice Albie Sachs, a professor of international constitutional law articulated the country's interplay between global and domestic jurisprudence. The Universal Declaration of Human Rights (UDHR), for example, "played an important role in the creation of a country called South Africa" (De Wet 1532). Indeed, the constitution specifically states that, when interpreting domestic law, "an interpretation consistent with international law is to be preferred" (1533). In considering his own work as a Justice on the Court, Sachs stressed that, while the rise of the nation-state typically has led domestic courts to eschew international law, the free South Africa was imagined differently. "We are a new Court creating a new jurisprudence with the aid of a new and highly respected Constitution," he explained (Sachs 433-34).

The country's bifurcation during the apartheid years illuminated a stark contrast between the racist domestic laws of South Africa and the progressive language in international legal

${ }^{224}$ See, for example, Slaughter, Human Rights, Inc. and Anker, Fictions of Dignity. 
documents. This juridical binary meant that "international law was seen as the progressive 'other' of Apartheid: the adequate, civilized, and principled response to all the illegalities and indignities that resulted from systematic racial discrimination" (De Wet 1532). As such, the framers of the Constitution took great care to craft language that "complied with international norms" (1531). Specifically, the Constitution mirrors certain protections granted by international human rights law treaties. In this way, the reliance on international law supports a claim that the South African Constitution might be conceived as a reparative text. In linking global laws to local needs, the framers repair the theoretical injuries incurred by the racist laws of apartheid.

In speaking of the government's reliance upon international law, Sachs implied that South Africa is merely a forerunner in subjecting local violence to a global remedy. "[B]oth violence and international norms on human rights have become globalized," he explained (433). Yet the seeds for this ameliorative intrusion of international human rights law into South African politics began more than fifty years ago. Narrating the biography of famed human rights lawyer Bram Fischer, literary scholar Stephen Clingman explained that the UDHR at times even became a significant defense document. As if ever-embedded in the freedom struggle from the 1960s onward, the constitutional documents of the new South Africa also belie a bond with international jurisprudence. Espousing the language of equal rights, the UDHR became a symbolic text inscribed in the legal-political struggles of the country, and its language eventually was overlaid into the new Constitution.

On the flip side of importing international law into its own, South Africa has also positioned itself on the global stage with the ratification of its unique constitution and its implementation of the TRC. Accordingly, the country has become known as an example of a nation founded upon principles of human rights. The country is not free from the remnants of 
violence enacted under apartheid. Yet the reconciliatory foundations laid by its jurisprudence resound worldwide. Most notably, the TRC has become a model for truth commissions in those nations struggling with the after-effects of colonialism and tyranny. In its post-apartheid years, South African politics have welcomed international models as much as it has created them. And here, the legal comes to reflect upon the literary. While Gordimer's very localized novels have worked to undermine the racist politics of South Africa, her work has yielded limited readership in her own country but has become a global voice of resistance.

\section{Conclusion}

Through The House Gun, Gordimer depicts the possibilities and limitations of reconciliation in South Africa, registering their precise location in social, political, and psychic dimensions. At the same time, the novel reaches far beyond localized spaces, representing the country's struggle to recover from decades of political violence as a matter of urgent concern for the world. For many of Gordimer's readers, Johannesburg is a city known only through contemporary news reports about the end of apartheid and the rise of violent crime. But can tensions within such urban spaces recast our thinking about human recovery in other regions afflicted by segregation and institutionalized racism? Within the domestic realms of the South African courtroom and the upper-class home of the fictional Lindgards, the novel posits significant questions about social and spatial healing that remain to be answered. For instance, what does it mean for racial reconciliation if the protagonists of The House Gun are an upperclass white couple, and how does that fact reflect upon Gordimer's likely reader? And how do local practices for mending the wounds of apartheid affect restorative justice measures in the wider world? Solutions to political harms do not come easily through literary or legal means. 
Yet, The House Gun works to identify the elusive intersection of imaginative literature and the language of jurisprudence. Is it possible for fictional representations of justice in one localized region of the world to engage with international humanitarian dialogue? Gordimer never relinquishes the claim that fiction informs our ongoing political engagements; the stress and the urgency of this demand pervades the novel. 


\section{Coda:}

\section{A Future for Recuperative Global Narrative}

The field of transitional justice has developed rapidly in the past twenty years - from one rooted firmly in the legal sphere and with a focus on prosecutions and retributive justice, to a field that today integrates . . reparations for victims, memorialization initiatives, the rebuilding of social relationships, cultural and educational endeavors and the reintegration of combatants. Each of these elements has a role to play in acknowledging the past, prioritizing the needs of victims and restoring the humanity of all who are party to a conflict.

\section{—Desmond Tutu}

We are aware of our obligation to populate this space, and at the same time we realize our fundamental, our critical obligation to communicate in an uninhabited world which is no less filled with injustice, punishment, and pain because it is uninhabited.

-Pablo Neruda, Nobel Prize for Literature acceptance speech

What does successful redress of human injustice look like? And does it necessarily involve imaginative interventions? Roy L. Brooks posed this question at the end of the twentieth century, emphasizing that we live in an "age of apology" in which practitioners and theorists alike have begun to focus on victims' needs in the aftermath of mass violence. ${ }^{225}$ Yet the international criminal justice system continues to focus primarily on punishing perpetrators as a method of doing justice for human rights violations. ${ }^{226}$ While local courts can sometimes "play a

\footnotetext{
${ }^{225}$ See Roy L. Brooks, “Age of Apology,” in When Sorry Isn’t Enough: The Controversy Over Apologies and Reparations for Human Injustice, ed. Roy L. Brooks (New York: NYU Press, 1999): 3-9.

${ }^{226}$ As Brooks notes, "the victims can take matters into their own hands by seeking civil redress-money or other forms of relief - from the perpetrators under certain conditions," but this method is not an all-inclusive one. For, "when rights are ripped away, the victim or his family are entitled to compensation and much more." Brooks, "Age of Apology," 6.
} 
useful role in the redress process," there remains an urgent need to reconceptualize the terms of recovery for human injustice. ${ }^{227}$ Can expressions of restorative justice elucidated through imaginative literature provide new ways to address victim recovery? I have argued that deep connections exist between the juridical tasks of the legal system in response to political violence and the remedies that restorative narratives can produce.

This study offers a new possibility for law and literature, as it relies on a historical relation between the aims of the international criminal justice system and the recuperative potential of the global narrative. In the past several decades, victims' monetary redress claims and public calls for national apologies have been abundant. Yet policymakers, jurists, and theorists agree that, in an age of ever-increasing globalization, we need new ways to depict redress and to reconceptualize its terms and scope. ${ }^{228}$ Here, a new subfield of law and literature can open up the legal realm of restorative justice to a larger cultural one, populated by works of world literature, that invent new models for human recovery.

Restorative justice aims in literature emerged historically alongside the international criminal tribunal system. As lawmakers constructed the Universal Declaration of Human Rights (UDHR) and the Genocide Convention in the years immediately following World War II and the world's introduction to Nazi and Soviet totalitarianism, the novel began to address intertwined issues of victimhood and human repair. At the Nuremberg trials in 1945-46, the Allies focused on retributive justice, or punishing high-ranking Nazis for war crimes and crimes against humanity. As I have noted, Nuremberg served as an important foundation when, nearly fifty years later, construction began on the ad hoc tribunal for the former Yugoslavia in 1993. And, likewise, Nuremberg became a counterpoint to the reconciliatory aims of South African's Truth

${ }^{227}$ Brooks, "Age of Apology," 6-7.
${ }^{228}$ Ibid. 
and Reconciliation Commission in 1995. This study begins with this historical framework, bringing together seemingly disparate novels that ultimately tell a story about the rehabilitative aims of world literature its multifaceted possibilities for victim redress.

At the turn of the twenty-first century, Sebald's fiction reminds us of the unfinished work of victim healing at Nuremberg, and urges us to investigate the potential for narrative restoration apart from current cultural practices of remembrance. In Darkness at Noon, we see the bodily recovery and reconstitution of self-consciousness through Rubashov, a character at once trapped in totalitarian ideology yet able to break free through the power of literature. The forgotten record of Soviet totalitarianism within the history of Nuremberg returns to prominence in Hemon's work, where the communist injuries inflicted upon Eastern Europe during the second half of the twentieth century culminate in the geopolitical violence witnessed during the Siege of Sarajevo. Given the magnitude of historical wounds in his novel, Hemon invites his reader to repair the broken histories of the Balkans. Indeed, through reading practices that elicit collecting impulses and laughter at political jokes, we begin to create a historical record that speaks to the restorative needs and aims of the ICTY. And while the limitations of a legal approach to victim recovery loom large in The Question of Bruno, we find that Gordimer's fiction reinvents the South African courtroom and cityscape as spaces of reconciliatory potential. While the novels in this project have regional and national implications, together each speaks to possibilities of global redress in relation to the juridical attention to international human rights law.

At the same time, this historical framework serves only as an introduction to the recuperative power of narrative. To further explore the possibilities of restorative justice and global literature, we would need to turn to the years of stasis between the tribunals in which no international trials were convened. In this intermediary period, local agitations produced new 
ideas about reconciliation in the face of human rights abuses. Specifically, the injuries of the 1947 India-Pakistan Partition have been taken up by postcolonial authors in subsequent decades, such as Bapsi Sidhwa, who seek to understand the implications for stark geographic and ethnic fractures, and the ability to recover from imperial violence; literature from the American Civil Rights movement in the 1950s and 1960s speaks to continued decolonization struggles in Francophone Africa and its emphasis on reparative violence and oppositional uprisings; countries of the Southern Cone endured the political oppression associated with Operation Condor in the 1960s, 70s, and 80s, and new aesthetic forms there responded to new traumatic wounds. How do these years of stasis, in which the European Court of Human Rights appeared and the United Nations developed its Convention Against Torture, ${ }^{229}$ bear upon the historical framework of the international criminal justice system and attending restorative fiction? We might look to seminal works of recuperative literature to address the period between the tribunals, and the ways in which extra-legal modes of repair influence cultural notions of restorative justice.

For example, Bapsi Sidhwa's 1988 novel, Cracking India, depicts the India-Pakistan Partition through a coming-of-age story narrated by Lenny, a young Pakistani girl. The novel remaps the fractures of Partition upon the families and individual bodies of its characters, who exist "somewhere in the uncharted wastes of space" that the Indian subcontinent has become. Written more than forty years after Partition, Sidhwa's novel implies a recuperative need to

\footnotetext{
${ }^{229}$ While "torture continued to be systematically practiced in many parts of the world" after WWII, and "wellknown and documented cases during the 1960s and 1970s include[d] the French practices in Algeria, the Portuguese practices in its former African colonies, the practices under the Greek military junta and those under Latin American military dictatorships," the latter were among the most salient internationally. Amnesty International (AI) launched its first campaign against torture on Human Rights Day in 1972, but "most notorious were the cruel methods of torture practiced by the military junta under General Augusto Pinochet Ugarte, who had overthrown the democratically elected Salvador Allende in Chile on 11 September 1973." Indeed, "the widely documented cases of torture and enforced disappearances in Chile turned out to be the starting point for a number of far-reaching measures and reforms in international human rights law." Manfred Nowak and Elizabeth McArthur, The United Nations Convention Against Torture: A Commentary (New York: Oxford UP, 2008), p. 3
} 
return to the period of Partition and its aftermath. How do we understand the local politics of India and Pakistan in relation to postwar decades rife with the violence of decolonization? And how might a novel reinscribe the memory of the immediate postcolonial experience to provide a means of reconciliation for future generations? Taking place just beyond the margins of Lahore's “Jail Street," Sidhwa's novel defines restorative justice outside the bounds of international jurisprudence as it "recollects the pain of old, caked wounds," as one critic described, "so that they may finally be healed."

The wounds of segregation — in national, racial, and ethnic terms — beg for an international response in the 1950s and 1960s in both the United States and Francophone Africa, yet imaginative narratives meet with local agitations instead to depict the reparative potential for violent uprisings. Specifically, Ellison's Invisible Man has long been recognized as a seminal work of American literature, yet it might readily be repositioned within the critical dialogue concerning social justice and globalization, a conversation that looms large for the decades following WWII. Notably, Ellison's novel appeared at the crux of a struggle for political rights in America that echoed throughout Anglophone and Francophone Africa. During the 1950s, the South African government enacted a policy of legal segregation: it forced removals of non-white citizens to townships and decimated non-white neighborhoods within central urban spaces. Ellison's novel poses important questions about the segregation of national spaces, while raising the issue of reparation for civil rights violations in America and abroad. Although the question of legal reparations were then unaddressed by international law, Invisible Man was prescient. In the late 1950s, Nadine Gordimer traveled to Washington, D.C. to give a lecture on the "problems of Apartheid." She drew a parallel between de jure segregation in the United States and in South Africa, calling on fiction writers to resist by reimagining the state in equalitarian terms. In 
dialogue with Frantz Fanon's Wretched of the Earth, Ellison's novel addresses Gordimer's call to action. Can violence repair political harms? As such, Ellison situates restorative justice within the transnational frameworks of anti-colonial struggles and anti-apartheid resistance. Given that segregation inflicts immense social and spatial harms, the novel asks us to consider the use of violence as a form of resistance and repair. Indeed, Invisible Man prepared the way for legal theories of reparation that ultimately influence domestic and international law alike in the years after the ICTY and the TRC. ${ }^{230}$

The connection between human rights and restorative justice takes a conspicuously transnational turn in the 1970s. Although recourse to international law remained limited, political opponents of the dictatorships in the Southern Cone undertook transnational movement both by choice and by force. More than many tyrannical regimes before them, those carrying out Operation Condor employed state policies of torture. Indeed, they supplied manuals depicting the proper methods for inflicting pain upon the human body. ${ }^{231}$ In 1984, Camnitzer exhibited a collection of textual paintings, "The Uruguayan Torture Series," at the Alternative Museum in New York City. Forced into exile from Montevideo, Camnitzer became a transnational artist by necessity. The series of paintings reflects the use of torture by the regimes in Uruguay, Argentina, Chile, and Brazil; within the images, dismembered bodies appear alongside seemingly banal English-language inscriptions that unsettle connections between image and

\footnotetext{
${ }^{230}$ In Roy L. Brooks' anthology, he brings together legal thinkers who also consider the recuperative quality of narrative. See, for example, Boris I. Bittker and Roy L. Brooks, "The Constitutionality of Black Reparations," in When Sorry Isn't Enough: The Controversy Over Apologies and Reparations for Human Injustice, ed. Roy L. Brooks (New York: NYU Press, 1999): 374-389; Joe R. Feagin and Eileen O’Brien, "The Long-Overdue Reparations for African Americans: Necessary for Societal Survival?," in When Sorry Isn't Enough: The Controversy Over Apologies and Reparations for Human Injustice, ed. Roy L. Brooks (New York: NYU Press, 1999): 417-421; C.J. Munford, "Reparations: Strategic Considerations for Black Americans," in When Sorry Isn't Enough: The Controversy Over Apologies and Reparations for Human Injustice, ed. Roy L. Brooks (New York: NYU Press, 1999): 422-426; Robert Johnson, Jr., "Repatriation as Reparations for Slavery and Jim-Crowism," in When Sorry Isn't Enough: The Controversy Over Apologies and Reparations for Human Injustice, ed. Roy L. Brooks (New York: NYU Press, 1999): 427-434.

${ }^{231}$ See Keith M. Slack, "Operation Condor and Human Rights: A Report from Paraguay's Archive of Terror," Human Rights Quarterly 18.2 (1996), 492-506, 492.
} 
language. According to Camnitzer, his work attempts "to produce a situation in which neither the image nor the text reveal too much. Only when they are seen together does something happen.” The exhibit permeated geographic borders as it depicted South American violence for a distinctly American audience. Yet it also crossed disciplinary borders, appearing on the eve of the U.N.'s ratification of the Convention Against Torture. An innovative form of global narrative, Camnitzer's collection provides new ways to read the bodily language of international law, and illumines distinct ideas about how an aesthetic intervention into political violence can reimagine the stakes of human rehabilitation. ${ }^{232}$ The "Uruguayan Torture Series" addresses local acts of political violence that traverse spatial and linguistic borders, staking out new possibilities for victim recuperation in the years between the international criminal tribunals.

Turning to the period of stasis in imaginative literature with the historical framework of the tribunals in mind can help to suggest the multifaceted connections between restorative narratives and juridical concerns. And these matters will continue to be of pressing concern in our contemporary, legally focused world, which has come to be defined by the ongoing post-9/11 period, the staying power of the International Criminal Court in the Hague, and the proliferation of truth commissions across the globe. On its surface, modern and contemporary world literature represents and responds to issues of victimhood, criminality, and the far-reaching effects of mass violence. But do imaginative texts merely respond to political crises? My study ultimately is guided by the tenet that imaginative global narrations move beyond this passive role to engage with and reimagine central principles of juridical scholarship and lived experience. How do we position humanistic inquiry in an age defined, in part, by terror? Matters of tyranny, violence,

\footnotetext{
${ }^{232}$ See, for example, Jean Amery, "Torture," in At the Mind's Limits: Contemplations by a Survivor on Auschwitz and its Realities (Bloomington: U of Indiana Press, 1980); Elaine Scarry, The Body in Pain: The Making and Unmaking of the World (New York: Oxford UP, 1987); Susan Sontag, Regarding the Pain of Others (New York: Farrar, Straus and Giroux, 2003).
} 
and ideology that played important roles in the immediate postwar period at Nuremberg continue to resonate with urgency in contemporary culture. Questions about immigration and refugeeism show themselves through (illegal) border crossings and shifting ideas about citizenship and political rights in a climate marked by global exchange. What does it mean to be secure in our persons? How do we understand terms of justice? And how do formal distinctions among different media — the novel, poetry, cinema, and visual art —influence the recuperative power of narrative? In many ways, these matters engage directly with the nature of human rights, the problematic assumptions underlying them, and the new potential for restorative justice through aesthetic engagement. By invoking the term of global fiction, we can reconstitute a new subfield in law and literature that opens restorative justice and juridical inquiry to the social and imaginative practices of reconciliation. 


\section{Works Cited}

Adorno, Theodor. Prisms. Transl. Samuel and Shierry Weber. 1967. Cambridge: MIT UP, 1997.

Amery, Jean. “Torture." In At the Mind's Limits: Contemplations by a Survivor on Auschwitz and its Realities. Bloomington: U of Indiana Press, 1980.

Amnesty International and Human Rights Watch, “Truth and Justice, Unfinished Business in South Africa,” Summary AI Index 521001/2003, February 2001.

Anker, Elizabeth. Fictions of Dignity: Embodying Human Rights in World Literature. Ithaca: Cornell UP, 2012. Print.

Appadurai, Arjun, ed. Globalization. Durham: Duke UP, 2001.

Arendt, Hannah. Eichmann in Jerusalem: A Report on the Banality of Evil. 1963.

Reprint. New York: Penguin Books, 2006.

-----. The Origins of Totalitarianism. Orlando: Harcourt, 1951.

AZAPO v. President of the Republic of South Africa, CCT 17/96, Constitutional Court, 17 July 1996.

Bakhtin, Mikhail. The Dialogic Imagination: Four Essays. Trans. Caryl Emerson and Michael Holquist. Austin: U of Texas Press, 1981.

Baldwin, Hanson. "Russia: The Bosses and the Moujiks." The New York Times 29 July 1956: SM24. Print.

Balibar, Etienne and Immanuel Wallerstein. Race, Nation, Class: Ambiguous Identities. London: Verso, 1991.

Balzac, Honore. Colonel Chabert. 1832. New York: Quill Pen Classics, 2008.

Barish, Mildred. "Trial of Soviet Ex-Official Stresses Regime’s Brutality.” Los Angeles 
Times 1 June 1941: C6. Print.

Barnard, Rita. Apartheid and Beyond: South African Writers and the Politics of Place. New York: Oxford UP, 2007. Print.

Barthes, Roland. "The Discourse of History," in Comparative Criticism 3 (1981): 7.

Basic Principles and Guidelines on the Right to a Remedy and Reparation for Victims of Gross Violations of International Human Rights Law and Serious Violations of International Humanitarian Law, G.A. Res. 60/147, U.N. Doc A/RES/60/147 (Dec. 16, 2005).

Benjamin, Walter. “A Berlin Chronicle.” In Reflections: Essays, Aphorisms, and Autobiographical Writing, ed. Peter Demetz. New York: Schocken Books, 1986.

------. The Arcades Project. Cambridge: Harvard UP, 1999.

------. “On Language,” in Reflections. New York: Schocken, 1968.

-----. “Task of the Translator,” in Illuminations. New York: Schocken, 1968.

Birchall, Ian H. Sartre Against Stalinism. Paris: Berghahn Books, 2004.

Bittker, Boris I. and Roy L. Brooks. "The Constitutionality of Black Reparations." In When Sorry Isn't Enough: The Controversy Over Apologies and Reparations for Human Injustice, ed. Roy L. Brooks. New York: NYU Press, 1999, 374-389;

Blackler, Deane. Reading W.G. Sebald: Adventure and Disobedience. London: Camden House, 2007.

Blohm, Katharina et al. Bauen im Nationalsozialismus: Bayern 1933-45. Muenchen: Architekturmuseum der Technischen Universitaet Muenchen, 1993.

Bloom, Harold. Darkness at Noon: Bloom's Modern Critical Interpretations Philadelphia: Chelsea House, 2003.

Bloxham, Donald. "Milestones and Mythologies: The Impact of Nuremberg." In Atrocities on 
Trial: Historical Perspectives on the Politics of Prosecuting War Crimes. Lincoln: $U$ of Nebraska Press, 2008.

Bentham, Jeremy. Panopticon, Or the Inspection House. 1791. Reprint. Lausanne: U of Lausanne Press, 2008.

Berkowitz, Roger. “Approaching Infinity: Dignity in Arthur Koestler's Darkness at Noon," in Philosophy and Literature 33 (2009): 296-314. Print.

Boraine, Alex. A Country Unmasked: Inside South Africa's Truth and Reconciliation Commission. New York: Oxford UP, 2000. Print.

Borer, Tristan Anne. “A Taxonomy of Victims and Perpetrators: Human Rights and Reconciliation in South Africa.” In Human Rights Quarterly 25 (2003): 1088-1116.

Borling, John. Poems from the Hanoi Hilton. New York: Green Leaf Book Group, 2013.

Bouckaert, Peter Norbert. "Shutting Down the Death Factory: The Abolition of Capital Punishment in South Africa," in Stanford Journal of International Law 32 (1996): 287.

Braine, John. "Why One British Socialist Turned Conservative: A Socialist turns Conservative.” The New York Times 2 March 1969: SM24. Print.

Braithwaite, John. "Restorative Justice and a Better Future.” In A Restorative Justice Reader, ed. Gerry Johnstone. New York: Routledge, 2003.

Breendonk Memorial Official Website, available at http://www.breendonk.be/EN/index.html (last visited Feb. 4, 2014).

Bremner, Lindsay. Judin, Hilton and Ivan Vladislavić editors. Blank-: Architecture, Apartheid and After. New York: Distributed Art Publishers, 2008. Print.

Brenez, Nicole and Adrian Martin. "Serious Mothlight: For Stan Brakhage.” Rouge (2003).

Brooks, Peter. Reading for the Plot: Design and Intention in Narrative. New York: 
Knopf, 1992.

-----. Troubling Confessions: Speaking Guilt in Law and Literature. Chicago: U of

Chicago Press, 2000.

Brooks, Roy L. “Age of Apology.” In When Sorry Isn't Enough: The Controversy

Over Apologies and Reparations for Human Injustice, ed. Roy L. Brooks. New York:

NYU Press, 1999, 3-9.

------. “What Price Reconciliation?” In When Sorry Isn't Enough: The Controversy

Over Apologies and Reparations for Human Injustice, ed. Roy L. Brooks. New York:

NYU Press, 1999, 443-447.

Brown, Kris. "Historical Justice in International Perspective: How Societies are Trying to Right the Wrongs of the Past.” In Perspectives on Politics 8 (2010), 965-968

Brown, Wendy. "Suffering the Paradoxes of Rights." In Left Legalism/Left Critique, ed. Wendy Brown and Janet Halley. Durham: Duke UP, 2002.

Buckley, William F., Jr. "50 Years of Communism.” The New York Times 7 Sept. 1973:

4. Print.

Camnitzer, Luis. From the Uruguayan Torture Series, photo-etchings on canvas, 1984

(Alternative Museum, New York).

Chaplin, Charlie. The Great Dictator. Film. Directed by Charlie Chaplin. 1940. Los Angeles, CA: United Artists, 2001. DVD.

Christmeier, Martina. Interview conducted in Nuremberg, Germany. July 23, 2012.

Clingman, Stephen. Bram Fischer: Afrikaner Revolutionary. Amherst: U of Massachusetts Press, 1998. Print.

-----. The Novels of Nadine Gordimer: History from the Inside. Boston: Allen \& Unwin, 1986. 
Print.

----- "Surviving Murder: Oscillation and Triangulation in Nadine Gordimer's The House Gun," in Modern Fictions Studies 46 (2000): 139.

Colpitt, Frances. Minimal Art: The Critical Perspective. Seattle: U of Washington Press, 1993.

Combs, Nancy. Guilty Pleas in International Criminal Law: Constructing a Restorative Justice Approach. Stanford: Stanford UP, 2007

Comprehensive Anti-Apartheid Act of 1986, S. 2701 (99 ${ }^{\text {th }}$ Congress, 1985-1986). July 30, 1986.

Cowley, Malcolm. Think Back on Us: A Contemporary Chronicle of the 1930s.

Carbondale: Southern Illinois UP, 1967.

Cubilie, Anne. Women Witnessing Terror: Testimony and the Cultural Politics of Human

Rights. New York: Fordham UP, 2005.

Criminal Procedure Code of the Court of Bosnia and Herzegovina, available at http://www.coe.int/t/dlapil/codexter/Source/country_profiles/legislation/CT\%20Legislati on $\% 20-\% 20 \mathrm{BiH} \% 20 \mathrm{Criminal} \% 20$ Procedure $\% 20$ Code.pdf.

Damrosch, David. "World Literature in a Postcanonical, Hypercanonical Age." In Comparative Literature in an Age of Globalization, edited by Haun Saussy, 43-53. Baltimore, JHU Press, 2006.

Danto, Arthur C. Narration and Knowledge. New York, Columbia UP, 1985.

Dean, Carolyn J. Aversion and Erasure: The Fate of the Victim After the Holocaust. Ithaca: Cornell UP, 2010.

Deak, Istvan, Jan T. Gross, and Tony Judt. The Politics of Retribution in Europe: World War II and its Aftermath. Princeton: Princeton UP, 2000.

De Certeau, Michel. The Practice of Everyday Life. Trans. Steven Rendall. 1984. Berkeley: U 
of California Press, 2011.

Deleuze, Gilles. Difference and Repetition. 1968. New York: Columbia UP, 1994.

De Wet, Erika. “The 'Friendly But Cautious' Reception of International Law in the Jurisprudence of the South African Constitutional Court: Some Critical Remarks," in Fordham International Law Journal 28 (2005): 1529.

Eagleton, Terry. "Deconstruction and Human Rights." In Freedom and Interpretation: The Oxford Amnesty Lectures 1992, edited by Barbara Johnson, 122-145. New York: Basic Books, 1993.

-----. Walter Benjamin, or Towards a Revolutionary Criticism. London: Verso, 1981.

Elliott, J.E. "Brecht and the Jokes of Theory." MLN 113 (1998): 1056-1088. Print.

Ellison, Ralph. Invisible Man. New York: Random House, 1952. Print.

Emerson, Caryl. “Answering for Central and Eastern Europe.” In Comparative Literature in an Age of Globalization, edited by Haun Saussy, 203-211. Baltimore, JHU Press, 2006.

Enweznor, Okwui. "Contemporary African Art Since 1980.” In Africaerver Magazine. Johannesburg: April 27, 2010.

Ewick, Patricia and Susan Silbey. The Common Place of Law: Stories from Everyday Life. Chicago: U of Chicago Press, 1998.

Eyman, Scott. Ernst Lubitsch: Laughter in Paradise. Baltimore: JHU Press, 2000.

Fanon, Frantz. The Wretched of the Earth, trans. Richard Philcox. 1961. New York: Grove Press, 2004. Print.

Feagin, Joe R. and Eileen O'Brien. “The Long-Overdue Reparations for African Americans: Necessary for Societal Survival?.” In When Sorry Isn't Enough: The Controversy Over Apologies and Reparations for Human Injustice, ed. Roy L. Brooks. New York: NYU 
Press, 1999, 417-421

Felman, Shoshana. The Juridical Unconscious: Trials and Traumas in the Twentieth Century. Cambridge: Harvard UP, 2002.

Felman, Shoshana \& Dori Laub. Testimony: Crises of Witnessing in Literature, Psychoanalysis, and History. New York: Routledge, 1992.

Finci, Peter. Interview conducted at the ICTY in the Hague, Netherlands. July 13, 2012.

First Annual Report of the International Tribunal for the Prosecution of Persons Responsible for Serious Violations of International Humanitarian Law Committed in the Territory of the Former Yugoslavia since 1991 to the Security Council and the General Assembly, UN Doc A/49/342-S/1994/1007 (29 August 1994).

Fitzpatrick, Sheila. The Cultural Front: Power and Culture in Revolutionary Russia. Ithaca: Cornell UP, 1992. Print.

Foucault, Michel. Discipline \& Punish: The Birth of the Prison. 1975. Reprint. New York: Random House, 2012. Print.

-----. The Order of Things: An Archaeology of the Human Sciences. New York: Pantheon Books, 1970.

-----.. "Prison Talk." Power/Knowledge: Selected Interviews and Other Writings, 1972-1977. New York: Random House, 1980. Print.

Fritzche, Peter. "Sebald's Twentieth-Century Histories." In W.G. Sebald: History, Memory, Trauma, eds. Scott D. Denham, Mark Richard McCulloh, and Walter de Gruyter. Urbana: Illinois UP, 2006: 291-300.

Futamura, Madoka. War Crimes Tribunals and Transitional Justice: The Tokyo Trial and the Nuremberg Legacy. New York: Routledge, 2008. 
General Report to the Combined Staffs of the Office by Dr. Jacob Robinson on the Nuremberg War Criminals Trial, Thursday, December 6, 1945. World Jewish Congress archives.

Gikandi, Simon. "Narration in the Postcolonial Moment: Merle Hodge's 'Crick Crack Monkey."” In ARIEL: A Review of International English Literature 20 (1989), 15.

Goldstone, Richard. Lecture at the University of Virginia, March 15, 2012

------. "Forward." In Between Vengeance and Forgiveness. Boston: Beacon Press, 1998.

Gordimer, Nadine. “African Writing.” In The Essential Gesture: Writing, Politics and Places. New York: Penguin Group, 1989.

-----. A World of Strangers. 1958. Harmondsworth: Penguin, 1983. Print.

------. Bennington lecture, The Papers of Nadine Gordimer. Lilly Library at Indiana UniversityBloomington (1990).

-----. Burger's Daughter. London: Jonathan Cape, 1979. Print.

-----. The House Gun. New York: Farrar, Straus, \& Giroux, 1998. Print.

------. The House Gun drafts, various draft stages. Obtained at the Nadine Gordimer papers, Indiana University, Bloomington.

-----. July's People. New York: Penguin, 1982. Print.

------. "Our Violent Society," paper given in a panel discussion in violence in South Africa, the Weekly Mail Book Week, Market Theatre, Johannesburg. November 11, 1990.

-----. “Who Writes? Who Reads? The Concept of a People's Literature.” Lecture given in Dakar, November 27, 1989. Document obtained from the Nadine Gordimer Papers, Indiana University, Bloomington.

-----. "The Writer's Imagination and the Imagination of the State." Address to PEN Congress, 1986. Gordimer Paper archives at Indiana University, Bloomington. 
-----. "Writing and Being." In The Charles Eliot Norton Lectures 1994. Cambridge: Harvard UP, 1995.

Gordon, Peter E. "Review." In Aversion and Erasure: The Fate of the Victim After the Holocaust. Ithaca: Cornell UP, 2010.

Gutmann, A. and D. Thompson, "The Moral Foundation of Truth Commissions,” April 19, 1998. Obtained from South African History Archive.

Hallett, George. District Six Revisted. Johannesburg: Witswatersrand UP, 2007. Print.

Hardt, Michael and Antonio Negri. Empire. Cambridge: Harvard UP, 2000.

Harlow, Barbara. Resistance Literature. New York: Methuen, 1987.

Heberer, Patricia and Jurgen Matthaus, "War Crimes Trials and the Historian.” In Atrocities on Trial: Historical Perspectives on the Politics of Prosecuting War Crimes. Lincoln: U of Nebraska Press, 2008.

Hemon, Aleksandar. The Book of My Lives. New York: Farrar, Straus \& Giroux, 2013. Print.

-----. "Introduction," in Danilo Kis, Garden, Ashes. Chicago: Dalkey Archive Press, 2003.

-----. The Question of Bruno. New York: Farrar, Straus \& Giroux, 2000. Print.

Hunt, Lynn. Inventing Human Rights: A History. New York: W.W. Norton \& Co., 2007.

Huyssen, Andreas. Present Pasts: Urban Palimpsests and the Politics of Memory. Stanford: Stanford UP, 2003.

------. Twilight Memories: Marking Time in a Culture of Amnesia. New York: Routledge, 1995.

International Criminal Tribunal for the former Yugoslavia, Rules of Procedure and Evidence, U.N. Doc. IT/32/Rev.7 (1996), entered into force 14 March 1994, amendments adopted 8 January 1996. 
International Criminal Tribunal for the former Yugoslavia, Statute of the ICTY, SC res. 827,

UN SCOR 48th sess., 3217th mtg. at 1-2 (1993); 32 ILM 1159 (1993).

Ishiguro, Kazuo. A Pale View of Hills. London: Faber and Faber, 1982.

Jackson, Robert H. "Report to the President by Mr. Justice Jackson, October 7, 1946." In Report of Robert H. Jackson, United States Representative to the International Conference on Military Tribunals. Washington: Department of State, 1949.

-----. “Minutes of Conference Session of July 19, 1945.” In Report of Robert H. Jackson, United States Representative to the International Conference on Military Tribunals. Washington: Department of State, 1949.

------. Nuremberg Journal. Archival materials obtained from the Robert H. Jackson Center. Jamestown, NY.

Johnson, Robert Jr. "Repatriation as Reparations for Slavery and Jim-Crowism." In When Sorry Isn't Enough: The Controversy Over Apologies and Reparations for Human Injustice, ed. Roy L. Brooks. New York: NYU Press, 1999, 237-434

Jones, Spike. “Der Fuerher's Face.” Written by Oliver Wallace. Recorded by Spike Jones and His City Slickers, 1942.

Keltner, Dacher and George A. Bonnano. "A Study of Laughter and Dissociation: Distinct Correlates of Laughter and Smiling During Bereavement." Journal of Personality and Social Psychology 73 (1997): 687-702. Print.

Kentridge, William. Art from the Ashes. DVD. Princeton: Films for the Humanities \& Sciences, 1999.

Kim, Hubert. “German Reparations: Institutionalized Insufficiency.” In When Sorry Isn't 
Enough: The Controversy Over Apologies and Reparations for Human Injustice, ed. Roy L. Brooks. New York: NYU Press, 1999.

Klein, Melanie. Love, Guilt \& Reparation. London: Hogarth Press, 1981. Print.

Klüger, Ruth. Still Alive: A Holocaust Girlhood Remembered. New York: Feminist Press at CUNY, 2003.

Knight, Lania. "A Conversation with Aleksandar Hemon.” The Missouri Review 32 (2009): 84101. Print.

Koestler, Arthur. Arrow in the Blue. 1952. Reprint. New York: Stein \& Day, 1984.

-----. Darkness at Noon. 1940. Reprint. New York: Vintage, 2004.

-----. Scum of the Earth. London: Jonathan Cape, 1941.

Kristeva, Julia. Melanie Klein. New York: Columbia UP, 2013.

-----. Powers of Horror: An Essay on Abjection. New York: Columbia UP, 1982.

Kruger, Loren, "Filming the Edgy City: Cinematic Narrative and Urban Form in Postapartheid Johannesburg," in Research in African Literatures 37 (2006): 141-63LaCapra, Dominick. Writing History, Writing Trauma. Baltimore: JHU Press, 2013. Print.

Leys, Ruth. Trauma: A Genealogy. Chicago: U of Chicago Press, 2010. Print.

London, Ross. “A New Paradigm Arises.” In A Restorative Justice Reader, ed. Gerry Johnstone. New York: Routledge, 2003.

Lubitsch, Ernst. To Be or Not to Be. Film. Directed by Ernst Lubitsch. 1942. Los Angeles, CA: United Artists, 2002. DVD.

Macfarlane, Robert. "W.G. Sebald: Reveries of a Solitary Walker." In The Guardian, April 19, 2013.

Mandate and Crimes Under ICTY Jurisdiction, available at http://www.icty.org/sid/320 (last 
accessed February 5, 2014).

Marin, Natividad Martinez. "Nadine Gordimer's Later Novels Or: The Fiction of Otherness.” In Embracing the Other: Addressing Xenophobia in the New Literatures in English, ed. Dunja M. Mohr. Amsterdam: Rodopoi Press, 2008.

Marrus, Michael. "Forward," In Atrocities on Trial: Historical Perspectives on the Politics of Prosecuting War Crimes. Lincoln: U of Nebraska Press, 2008.

------. “The Holocaust at Nuremberg." In Yad Vashem Studies 26 (1998).

Mengel, Ewald and Michela Borzaga. Trauma, Memory, and Narrative in the Contemporary South African Novel: Essays. Amsterdam: Rodopi Press, 2012.

Mengel, Ewald, Michela Borzaga, and Karin Orantes. Trauma, Memory, and Narrative in South Africa: Interviews. Amsterdam: Rodopi Press, 2010.

Michaels, Anne. Fugitive Pieces. New York: Alfred A. Knopf, 1997.

Mignolo, Walter. Local Histories/Global Designs: Coloniality, Subaltern Knowledges, and Border Thinking. Princeton: Princeton UP, 2000.

Minow, Martha. Between Vengeance and Forgiveness: Facing History After Genocide and Mass Violence. Boston: Beacon Press, 1998.

Mofokeng, Santu. House of Bondage. New York: Random House, 1967. Print.

Munford, C.J. "Reparations: Strategic Considerations for Black Americans." In When Sorry Isn't Enough: The Controversy Over Apologies and Reparations for Human Injustice, ed. Roy L. Brooks. New York: NYU Press, 1999, 422-426

Mzansi Magic. Liliesleaf. Film/documentary. Johannesburg, August 2013.

Nabti, Najwa. Interview conducted at the International Criminal Tribunal for the Former Yugoslavia in the Hague, Netherlands. July 13, 2012. 
Neruda, Pablo. "Poetry Shall Not Have Sung in Vain.” In Passions and Impressions, eds.

Matilde Neruda and Miguel Otero Silva. Transl. Margaret Sayer Peden. New York: Farrar, Straus and Giroux, 1983. Print.

"Nobel Laureate Nadine Gordimer Attacked." In The Guardian, October 30, 2006, available at http://www.theguardian.com/books/2006/oct/30/nadinegordimer.

Nowak, Manfred and Elizabeth McArthur. The United Nations Convention Against Torture: A Commentary. New York: Oxford UP, 2008.

Nussbaum, Martha Craven. Poetic Justice: The Literary Imagination and Public Life. Boston: Beacon Press, 1995.

Ogletree, Charles J. "Repairing the Past: New Efforts in the Reparations Debate in America," in Harvard Civil Rights-Civil Liberties Law Review 38 (2003): 279.

Orwell, George. Nineteen Eighty-Four. 1949. Reprint. New York: Penguin Classics, 2013.

----. "Why I Write." A Collection of Essays. New York: Houghton Mifflin, 1970.

Parekh, Serena. "Resisting 'Dull and Torpid' Assent: Returning to the Debate Over the Foundations of Human Rights." Human Rights Quarterly (2007).

Paterson, Nancy. "Silencing Victims in International Courts," Georgetown Journal of International Affairs, 2003, p. 99.

Peters, Julie Stone. "Law, Literature, and the Vanishing Real: On the Future of an Interdisciplinary Illusion.” 120 PMLA: Publications of the Modern Language Association (2005). 442.

Power, Samantha. A Problem from Hell: America and the Age of Genocide. New York: Harper Collins, 2003. Print.

Preston, Julia. "U.N. Security Council Establishes Yugoslav War Crimes Tribunal; Judicial 
Panel is 1st Such Body Since Nuremberg." In Washington Post, February 23, 1993, A1. Promotion of National Unity and Reconciliation Act 34 of 1995.

Prosecutor v. Dragan Nikolic, IT-94-2-S, International Criminal Tribunal for the former Yugoslavia. December 18, 2003.

Prosecutor v. Kupreskic et al. (Trial Judgement), IT-95-16-T, International Criminal Tribunal for the former Yugoslavia (ICTY). January 14, 2000.

Prosecutor v. Milan Lukic; Sredoje Lukic, IT-98-32/1-T, International Criminal Tribunal for the former Yugoslavia. July 20, 2009.

Raful, Lawrence. “A Jewish Lobby at Nuremberg: Jacob Robinson and the Institute of Jewish Affairs, 1945-46." In The Nuremberg Trials: International Criminal Law Since 1945, ed. Herbert R. Reginbogin et al. Munich: K.G. Saur, 2006.

Ramirez, Mari Carmen. "Moral Imperatives: Politics as Art in Luis Camnitzer.” In Luis Camnitzer: Retrospective Exhibition 1966-1990, ed. Jane Farver. Bronx: Lehman College Art Gallery, 1991: 4-13.

Ranciere, Jacques. "Who is the Subject of the Rights of Man?" South Atlantic

Quarterly. Vol. 103, Number 2/3 (Spring/Summer 2004). 297-310.

Ratner, Steven R. and Jason Abrams. Accountability for Human Rights Atrocities in International Law: Beyond the Nuremberg Legacy. New York: Oxford UP, 1997.

Reichman, Ravit. “Committed to Memory: Rebecca West's Nuremberg." In Law and Catastrophe, eds. Austin Sarat, Larence Douglas, and Martha Merrill Umphrey. Stanford: Stanford UP, 2007.

-----. The Affective Life of Law: Legal Modernism and the Literary Imagination. Stanford: Stanford UP, 2009. 
Reznikoff, Charles. Holocaust. Los Angeles, Black Sparrow Press: 1975.

Rohter, Larry. “Aleksandar Hemon's Twice Told Tales: Displaced in America,” New York Times, May 15, 2009.

Sv Kalogoropoulos, SACR 12 (A), November 13, 1993.

Sv Makwanyane and Another, CCT3/94 [1995] ZACC 3; 1995 (6) BCLR 665; 1995 (3) SA 391; [1996] 2 CHRLD 164; 1995 (2) SACR 1, June 6, 1995.

Sachs, Albie. "War, Violence, Human Rights, and the Overlap Between National and International Law: Four Cases Before the South African Constitutional Court," in Fordham International Law Journal 28 (2005): 432.

Sartre, Jean-Paul. Saint Genet: Actor and Martyr. 1952. Reprint. Minneapolis: Minnesota UP, 2012.

-----. The Imaginary: A Phenomenological Psychology of the Imagination. 1940. Reprint. New York: Routledge, 2004.

Scarry, Elaine. The Body in Pain: The Making and Unmaking of the World. Oxford: Oxford UP, 1987.

Schabas, William. Genocide in International Law: The Crime of Crimes. New York: Cambridge UP, 2000.

Scheffer, David. All the Missing Souls: A Personal History of the War Crimes Tribunals. Princeton: Princeton UP, 2012.

Sebald, W.G. Austerlitz. Trans. Anthea Bell. New York: Random House, 2001.

------. Austerlitz. Muenchen: Carl Hanser Verlag, 2001.

-----. On the Natural History of Destruction, trans. Anthea Bell. New York: Random House, 2003. Print. 
Shabad, Theodore. "Soviet Dissidents and Confession." The New York Times 7 Sept. 1973: 4. Print.

Shermer, Michael \& Alex Gorbman. Denying History: Who Says the Holocaust Never Happened and Why Do They Say It? Berkeley: U of California Press, 2009. Print.

Shohat, Ella. Taboo Memories, Diasporic Voices. Durham, Duke UP, 2006.

Sidhwa, Bapsi. Cracking India: A Novel. Minneapolis: Milkweed Press, 1991.

Silberman, Marc. "Bertolt Brecht, Politics, and Comedy.” Social Research 79 (2012): 169-188. Print.

Simpson, Graeme. "Tell No Lies, Claim No Easy Victories-A Brief Evaluation of South Africa's TRC.” Paper from the South African History Archive, accessed May 2013.

Sinclair, Ian. "W.G. Sebald: Reveries of a Solitary Walker." In The Guardian, April 19, 2013.

Slack, Keith M. “Operation Condor and Human Rights: A Report from Paraguay's Archive of Terror.” In Human Rights Quarterly 18.2 (1996).

Slaughter, Joseph. Human Rights, Inc.: The World Novel, Narrative Form, and International Law. New York: Fordham UP, 2007.

----- “Master Plans: Designing (National) Allegories of Urban Space and Metropolitan Subjects for Postcolonial Kenya," in Research in African Literatures 35 (2004): 30.

Solzhenitsyn, Aleksandr Isaevich. The Gulag Archipelago, 1918-1956: An Experiment in Literary Investigation. New York: Harper and Row, 1974.

Sontag, Susan. Regarding the Pain of Others. New York: Farrar, Straus and Giroux, 2003. Print.

Spiegelman, Art. Maus. New York: Random House, 1997. 
Spivak, Gayatri. "Use and Abuse of Human Rights.” boundary 2: An International Journal of Literature and Culture. 32:1 (2005). 131-189.

Steele, Jonathan. “The Guardian Profile: Nadine Gordimer.” The Guardian, October 26, 2001, available at [http://www.theguardian.com/books/2001/oct/27/fiction.artsandhumanities].

Stockdale, James. "Dignity and Honor in Vietnam.” Wall Street Journal 16 April 1982: 32.

Stonebridge, Lyndsey. The Judicial Imagination: Writing After Nuremberg. Edinburgh:

Edinburgh UP, 2011.

Strauss, Harold. “The Riddle of the Moscow Trials: Arthur Koestler's Dramatic Novel Illuminates that Fantastic Episode.” New York Times 25 May 1941: 6.

Sulzberger, C.L. "Foreign Affairs: A Communist Postscript to 'Darkness at Noon' The Reappearance Better Communists.” The New York Times 25 July 1956: 28.

Suzman, Helen. "Transformation in South Africa: Cause and Effect," in Stanford Journal of International Law 32 (1996): 149.

Terezín Memorial Official Website, available at http://www.pamatnikTerezín.cz/showdoc.do?docid=164 (last visited Feb. 3, 2014).

“Translation," in Oxford English Dictionary, http://www.oed.com.proxy.its.virginia.edu/view/Entry/204844? redirectedFrom=translatio n\#eid, last accessed June 30, 2013.

Tucker, Robert C. and Stephen F. Cohen. The Great Purge Trial. Ed. New York: Grosset \& Dunlap, 1965.

U.N. General Assembly Resolution 96(I), Article 2 of the Convention on the Prevention and Punishment of the Crime of Genocide. 
Verdeja, Ernesto. Unchopping a Tree: Reconciliation in the Aftermath of Political Violence. Philadelphia: Temple UP, 2009. Print.

Walker, Margaret Urban. "Restorative Justice and Reparations.” In A Restorative Justice Reader, ed. Gerry Johnstone. New York: Routledge, 2003.

Waxman, Zoe Vania. Writing the Holocaust: Identity, Testimony, Representation. New York: Oxford UP, 2007.

Werle, G. "Without Truth No Reconciliation." Presentation at Institut fur Kriminalwissenschaft, Berlin, May 18. 1995.

“W.G. Sebald: Works \& Influences.” Conference. March 13-16, 2003, Davidson College, Davidson, NC.

Williams, Arthur. "W.G. Sebald: A Holistic Approach to Borders, Texts and Perspectives." In German-Language Literature Today: International and Popular, eds. A. Williams, S. Parkes, and J. Preece. New York: Oxford UP, 2000.

Wollheim, On Art and the Mind. Cambridge: Harvard UP, 1974.

Wood, James. "W.G. Sebald: Reveries of a Solitary Walker." In The Guardian, April 19, 2013.

Yeager, J. David. "The Human Rights Chamber for Bosnia and Herzegovina: A Case Study in Transitional Justice.” International Legal Perspective 14 (2004): 44-55. Print.

Young, James E. The Texture of Memory: Holocaust Memorials and Meaning. New Haven: Yale UP, 1993.

Zehr, Howard. "Retributive Justice, Restorative Justice.” In A Restorative Justice Reader, ed. Gerry Johnstone. New York: Routledge, 2003.

Zentgraf, Henrike. Interview conducted in Nuremberg, Germany. July 23, 2012. 
Zizek, Slavoj. First as Tragedy, Then As Farce. London: Verso, 2009.

Zweig, Ronald. German Reparations and the Jewish World: A History of the Claims

Conference. Portland: Frank Cass Publishers, 2001. 